Portland State University

PDXScholar

12-6-1994

\title{
Indicators of Nutrient Limited Plankton Growth in Lakes Near Mount Saint Helens, Washington
}

Kurt Davis Carpenter

Portland State University

Follow this and additional works at: https://pdxscholar.library.pdx.edu/open_access_etds

Part of the Biology Commons

Let us know how access to this document benefits you.

Recommended Citation

Carpenter, Kurt Davis, "Indicators of Nutrient Limited Plankton Growth in Lakes Near Mount Saint Helens, Washington" (1994). Dissertations and Theses. Paper 4874.

https://doi.org/10.15760/etd.6750

This Thesis is brought to you for free and open access. It has been accepted for inclusion in Dissertations and Theses by an authorized administrator of PDXScholar. Please contact us if we can make this document more accessible: pdxscholar@pdx.edu. 


\section{THESIS APPROVAL}

The abstract and thesis of Kurt Davis Carpenter for the Master of Science in Biology were presented December 6, 1994, and accepted by the thesis committee and the department.

COMMITTEE APPROVALS:

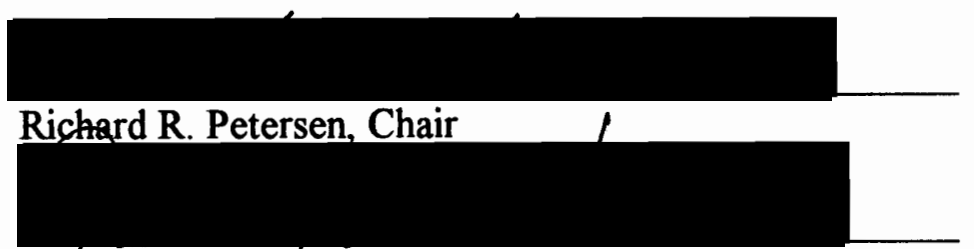

Joln G. Rueter

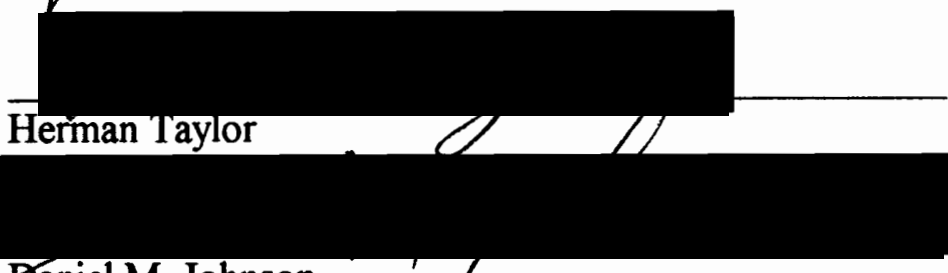

Đaniel M. Johnson

Representative of the Office of Graduate Studies

DEPARTMENT APPROVALS:

Leonard Simpson, Chair

Department of Biology

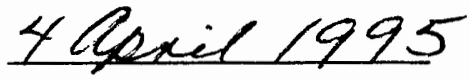


ABSTRACT

An abstract of the thesis of Kurt Davis Carpenter for the Master of Science in Biology presented December 6, 1994.

Title: Indicators of Nutrient Limited Plankton Growth in Lakes Near Mount Saint Helens, Washington

Several lakes located in the blast zone of the 1980 eruption of Mount St. Helens were studied to determine if the plankton in the lakes were limited in their growth by nitrogen or phosphorus availability. Long term nutrient enrichment experiments were performed on lake water from five lakes and measures of chlorophyll-a, carbon fixation, and nutrient uptake were used to evaluate the extent of limitation. Nutrient concentrations, ratios, and uptake from 14 lakes provided additional evidence for limitation by nitrogen and/or phosphorus. The physical, chemical, and biological characteristics of the lakes were also examined to monitor the return of these lakes to pre-eruption conditions.

Lakes heavily impacted by the 1980 eruption (Ryan, Fawn, and Hanaford Lakes) and newly formed Castle Lake produced positive responses to nitrogen additions, reflecting the continuing importance of nitrogen in these lakes. Evidence for colimitation by phosphorous was apparent in some of the lakes. Venus Lake, located near the fringe of the blast zone received less organic debris and responded only with phosphorus additions. Evaluations of nutrient depletion from the photic zones of these lakes during the growing season supported the results from the bioassays. Two measures of growth (chlorophyll-a and carbon fixation) often responded differently to enrichment, suggesting 
active algal and bacterial communities in some of the lakes. Qualitative measures of alkaline phosphatase activity normalized to chlorophyll-a indicated that those lakes which contained the highest dissolved organic carbon and bacterial counts following the eruption had higher alkaline phosphatase activities than less impacted lakes, suggesting bacterial enzyme production. Alkaline phosphatase activity confirmed that phosphorus limitation was more severe in lakes having less soluble reactive phosphorus.

Most of the lakes appear to be similar to other Cascade Mountain lakes, although many have reduced dissolved oxygen concentrations in the bottom waters during stratification. Incomplete mixing of these lakes during periods of circulation may regulate the decomposition of the organic material and hence, full recovery of these lakes. 
INDICATORS OF NUTRIENT LIMITED PLANKTON GROWTH

IN LAKES NEAR MOUNT SAINT HELENS, WASHINGTON

by

KURT DAVIS CYARPENTER

A thesis submitted in partial fulfillment of the

requirements for the degree of

MASTER OF SCIENCE

in

BIOLOGY

Portland State University

1995 


\section{ACKNOWLEDGEMENTS}

This thesis is dedicated to: all the solar energies that make their way through the food chains of life to acts of kindness, respect, and oneness; the people who devote their lives to matters which encourage and further education, preservation, and positivity; all the folks who have enlightened me to some of the natural wonders that exist. Special appreciation for my mother and father who encouraged me at a young age to explore this lively world. Their patience and encouragement have given me energy and direction. Very special thanks to Ian Waite, Bridget Bayer, and Tosh Kakar who I have shared some of the most incredible moments of my life...cheers. I would also like to send my most gracious thanks to Dr. Richard Petersen for advising this project and for his generous contribution to my continuing career in the aquatic sciences. Thanks also to all the good folks at the U.S. Geological Survey who provided much advice and encouragement. Special thanks to Clyde Doyle from the U.S. Geological Survey for providing quality control standards for the nutrient analyses. Special recognition goes to the U.S. Forest Service for providing the funding for this project. A multitude of thanks to Jon Moulton, Larry Scharnberg, Cyndi Baker, Kris Hueftle, Steve

Daggett, Gary Burns, Victor Menting, Peter Frenzen, Charles Crisafulli, Nancy Unsworth, and Abbas Saghedi who provided countless words of wisdom and quick thinking in the field. Thanks also to Dr. John Rueter, Dr. Herman Taylor, and Dr. Daniel Johnson for their efforts as advisors and committee members. All these good people have enriched my life through their acts of kindness and generosity... Peace 
TABLE OF CONTENTS

PAGE

ACKNOWLEDGEMENTS

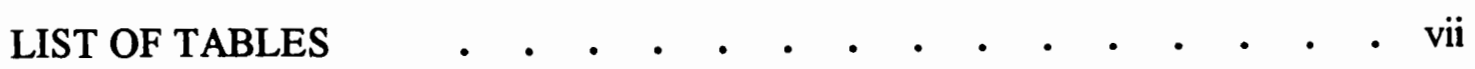

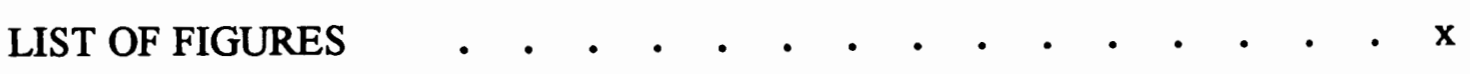

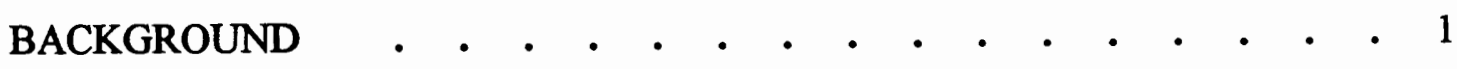

INTRODUCTION • • • • • • • • • • • • • • •

Phytoplankton Growth . . . . . . . . . . 6

Important Nutrients and their Sources $\quad . \quad \cdot \quad \cdot \quad \cdot \quad \cdot \quad \cdot \quad 8$

Nitrogen

Phosphorous

Silicon

Micronutrients

Seasonal Distribution of Nutrients.$\quad \cdot \quad \cdot \quad \cdot \quad \cdot \quad \cdot \quad \cdot \quad \cdot \quad \cdot 13$

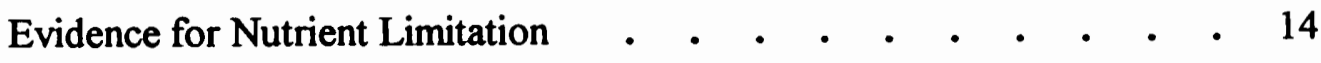

Depletion of Nutrient Pools

Deviations from Redfield Ratios

Phytoplankton Community Structure

Alkaline Phosphatase Activity

Fertilization Experiments

MATERIALS AND METHODS

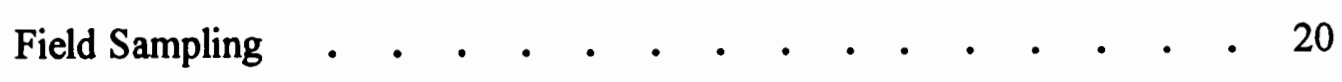

Water Samples

Lake Profiles 
Bioassay Experiments

Long Term Enrichment

Carbon Fixation

Alkaline Phosphatase

Laboratory Methods

Nitrate + Nitrite - Nitrogen

Ammonium - Nitrogen

Total Nitrogen

Soluble Reactive Phosphorous

Total Phosphorous

Silicon

Chlorophyll-a

Winkler Dissolved Oxygen

RESULTS AND DISCUSSIONS $\quad$ • • • • • • • • • • • • 27

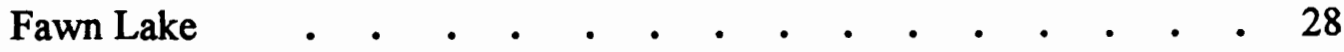

Temperature, Oxygen, and Light

Nutrient Dynamics

Nutrient Ratios

Bioassays

Alkaline Phosphatase

Long Term Enrichment

Conclusion

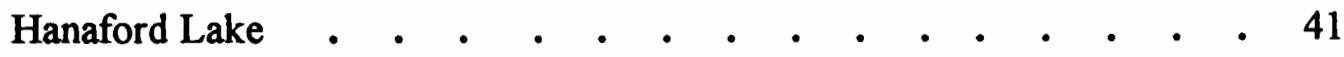

Temperature, Oxygen, and Light

Nutrient Dynamics

Nutrient Ratios

Bioassays

Alkaline Phosphatase

Long Term Enrichment

Conclusion 
Meta Lake

Temperature, Oxygen, and Light

Nutrient Dynamics

Nutrient Ratios

Alkaline Phosphatase Bioassay

Conclusion

Ryan Lake

Temperature, Oxygen, and Light

Nutrient Dynamics

Nutrient Ratios

Bioassays

Alkaline Phosphatase

Long Term Enrichment

Conclusion

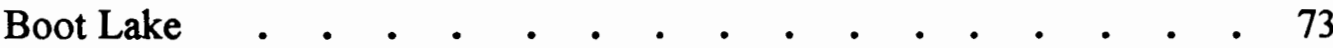

Temperature, Oxygen, and Light

Nutrient Dynamics

Nutrient Ratios

Conclusion

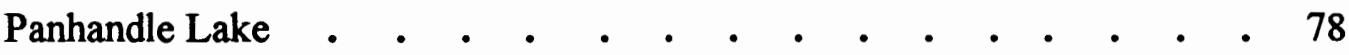

Temperature, Oxygen, and Light

Nutrient Dynamics

Nutrient Ratios

Alkaline Phosphatase Bioassay

Conclusion

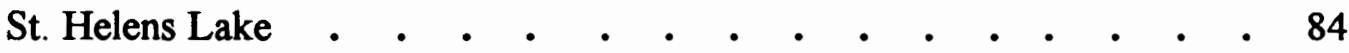

Temperature, Oxygen, and Light

Nutrient Dynamics

Nutrient Ratios

Conclusion 
Venus Lake

Temperature, Oxygen, and Light

Nutrient Dynamics

Nutrient Ratios

Long Term Enrichment Bioassay

Conclusion

Castle Lake

Temperature, Oxygen, and Light

Nutrient Dynamics

Nutrient Ratios

Bioassays

Alkaline Phosphatase

Long Term Enrichment

Conclusion

Coldwater Lake

Temperature, Oxygen, and Light

Nutrient Dynamics

Nutrient Ratios

Alkaline Phosphatase Bioassay

Conclusion

Blue Lake

Temperature, Oxygen, and Light

Nutrient Dynamics

Nutrient Ratios

Conclusion

June Lake

Temperature, Oxygen, and Light

Nutrient Dynamics

Nutrient Ratios

Alkaline Phosphatase Bioassay

Conclusion 
McBride Lake . . . . . . . . .

Temperature, Oxygen, and Light

Nutrient Dynamics

Nutrient Ratios

Alkaline Phosphatase Bioassay

Conclusion

Merrill Lake

Temperature, Oxygen, and Light

Nutrient Dynamics

Nutrient Ratios

Alkaline Phosphatase Bioassay

Conclusion

SUMMARY

Nutrient Concentrations as Determinants of Growth . . . . . 151

DIN and Chlorophyll-a Concentrations

SRP and Chlorophyll-a Concentrations

Nutrient Ratios and Limitation . . . . . . . . . . 157

The Relationship Between Nutrient Uptake and Nutrient Ratios . . . 158

Alkaline Phosphatase Activity as an Indicator of Nutrient Deficiency . . 160

CONCLUSION

Evaluations of Nutrient Limitation $\quad$ • . . . . . . . . . 165

The Return to Pre-Eruption Conditions . . . . . . . . . 167

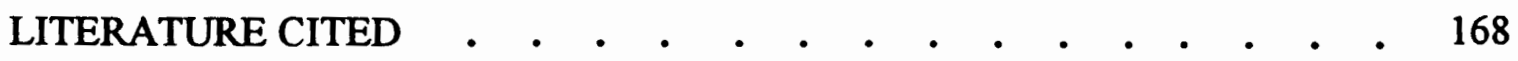

\section{APPENDICES}

A METHODS FOR LABORATORY ANALYSES . . . . . 172

B METHODS FOR BIOASSAY EXPERIMENTS . . • • . 177

C ABBREVIATIONS USED IN TEXT . . . . . . . . 187 


\section{LIST OF TABLES}

TABLE

PAGE

Nutrient and Chlorophyll-a Concentrations and Nutrient Ratios

\section{Blast Zone Lakes $\quad$ Date}

1. Fawn . . . . . $(5-22-93) \cdot$. . . . . . 38

2. Fawn . • • • • . (8-5-93) • • • • • • • 39

3. Fawn . . . . . (10-2-93) . . . . . . . . 40

4. Hanaford . . . . $(5-22-93)$. . . . . . . . 48

5. Hanaford . . . . . (8-5-93) . . . . . . . . 49

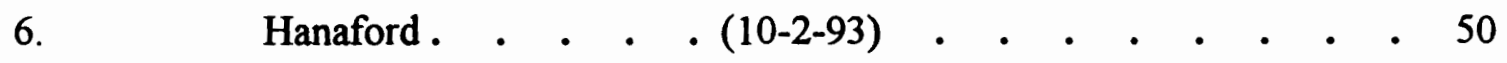

7. Meta . . . . . (6-17-93) . . . . . . 57

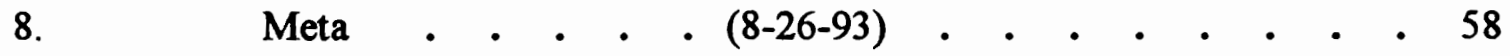

9. Meta . • . . . $\quad$ - (10-9-93) . . . . . . . 59

10. Ryan . . . . . $(6-17-93)$. . . . . . 70

11. Ryan . . . . . (8-24-93) • . . . . . . . 71

12. Ryan . . . . . (10-9-93) • . . . . . • 72

13. Boot . . . . . (8-15-93) . . . . . . . . 77

14. Panhandle . . . . $\quad$ ( $8-14-93)$. . . . . . . 83

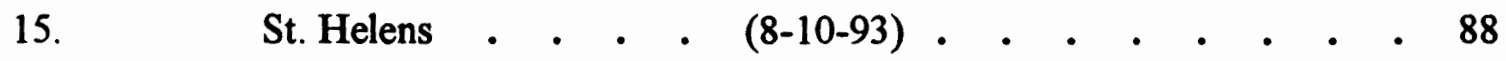

16. Venus • . . . . (8-9-93) • . . . . . . . 96 
Newly Formed Lakes

Date

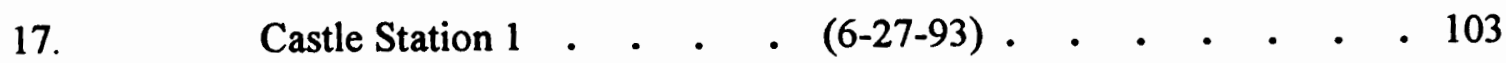

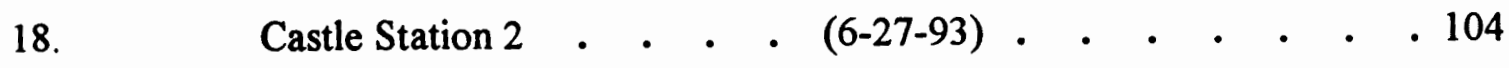

19. Castle Station 1 • . . . (9-18-93) • . • . . . . 105

20. Castle Station 2 • . . • (9-18-93) • • • • • • . 106

21. Coldwater Station 1 - • • (3-24-93) • • • • • • 114

22. Coldwater Station 2 - $\quad$ • (3-24-93) • • • • • • 115

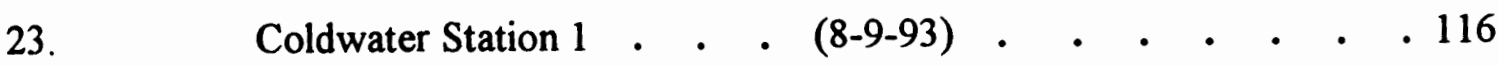

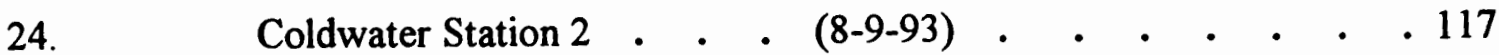

25. Coldwater Station 1 . • . (10-2-93) • • • • • . 118

26. Coldwater Station 2 • $\quad$ • $\quad$ (10-2-93) • • • • • • 119

\section{Lakes Outside Blast Zone $\quad$ Date}

27. Blue • . . . . . . (7-10-93) . . . . . . 123

28. June • • • • • • • (5-28-93) • • • • • • • 128

29. June • • • • • • • (9-9-93) • • • • • • 129

30. June • • • . • • • (10-16-93) • • • • • 130

31. McBride . . . . . . (5-28-93) . . . . . . 136

32. McBride • . • . • • (9-9-93) • • • • • • . 137

33. McBride • . . . . . (10-16-93) • • • • . 138

34. Merrill Station 1 . . . . (4-17-93) • • • • • • 144 
Lakes Outside Blast Zone $\quad$ Date

35. Merrill Station 2 • • • (4-17-93) • • • • • • 145

36. Merrill Station 1 • • • (9-8-93) • • • • • • 146

37. Merrill Station 2 • • • • (9-8-93) • • • • • • 147

38. Merrill Station 1 • • . . (10-17-93) • • • • • . 148

39. Merrill Station 2 • • • • (10-17-93) • • • • • • 149

40. Dissolved chemical characteristics and physical features

of lakes near Mount St. Helens, 1980 - . • . - . 155

41. Dissolved chemical and characteristics and light extinction data

from lakes near Mount St. Helens, $1993 \quad$ - $\quad$ - $\quad$ - $\quad$ - 156

42. Comparison of different approaches to nutrient limitation and

light data from lakes near Mount St. Helens, 1993 . $\quad$ - 157

43. Alkaline phosphatase activity and concentrations of SRP and

chlorophyll-a in lakes near Mount St. Helens, 1993 • • • 161 


\section{LIST OF FIGURES}

FIGURE

PAGE

1. Map showing locations of lakes near Mount St. Helens _ . - . - 21

2. Alkaline phosphatase activity in Fawn Lake, August 1993 . . . . 33

3. Chlorophyll-a response to enrichment in Fawn Lake, August 1993 . . $\quad 34$

4. Carbon uptake following enrichment in Fawn Lake, August 1993 . . 35

5. Oxygen, temperature, and light profiles in Fawn Lake, May 1993 • • 38

6. Oxygen, temperature, and light profiles in Fawn Lake, August 1993 . 39

7. Oxygen, temperature, and light profiles in Fawn Lake, October $1993 \quad$. $\quad 40$

8. Alkaline phosphatase activity in Hanaford Lake, August $1993 \quad$ • . $\quad$ - 44

9. Carbon uptake following enrichment in Hanaford Lake, August 1993 . $\quad 45$

10. Alkaline phosphatase activity following enrichment

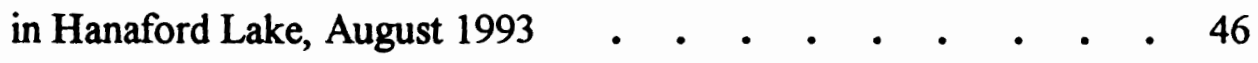

11. Oxygen, temperature, and light profiles in Hanaford Lake, May 1993 • $\quad$ - 48

12. Oxygen, temperature, and light profiles in Hanaford Lake, August 1993 . $\quad 49$

13. Oxygen, temperature, and light profiles in Hanaford Lake, October $1993 \quad$ - 50

14. Alkaline phosphatase activity in Meta Lake, October 1993 . . . . 55

15. Oxygen, temperature, and light profiles in Meta Lake, June $1993 \quad$ • $\quad$ - 57

16. Oxygen, temperature, and light profiles in Meta Lake, August $1993 \quad$ - 58

17. Oxygen, temperature, and light profiles in Meta Lake, October 1993 . 59

18. Alkaline phosphatase activity in Ryan Lake, October $1993 \quad$ - . . 65

19. Chlorophyll-a response to enrichment in Ryan Lake, August 1993 . . 66 
20. Carbon uptake following enrichment in Ryan Lake, August 1993 . . . 67

21. Alkaline phosphatase activity following enrichment in Ryan Lake, August 1993 . . . . . . . . . . 68

22. Oxygen, temperature, and light profiles in Ryan Lake, June 1993 . . 70

23. Oxygen, temperature, and light profiles in Ryan Lake, August 1993 . . 71

24. Oxygen, temperature, and light profiles in Ryan Lake, October $1993 \quad$ - 72

25. Oxygen, temperature, and light profiles in Boot Lake, August $1993 \quad$ • 77

26. Alkaline phosphatase activity in Panhandle Lake, July $1994 \quad$. . . 81

27. Oxygen, temperature, and light profiles in Panhandle Lake, August $1993 \quad$ - 83

28. Oxygen, temperature, and light profiles in St. Helens Lake, August $1993 \quad$ - 88

29. Chlorophyll-a response to enrichment in Venus Lake, August 1993 . . . 93

30. Carbon uptake following enrichment in Venus Lake, August 1993 . . 94

31. Oxygen, temperature, and light profiles in Venus Lake, August 1993 . . 96

32. Carbon uptake following enrichment in Castle Lake, September $1993 \quad$. 101

33. Oxygen, temperature, and light profiles in Castle Lake, station 1, June 1993 . . . . . . . . . . . 103

34. Oxygen and temperature profiles in Castle Lake, station 2, and light attenuation in Castle Lake, station 1, June 1993 . . . 104

35. Oxygen, temperature, and light profiles in Castle Lake,

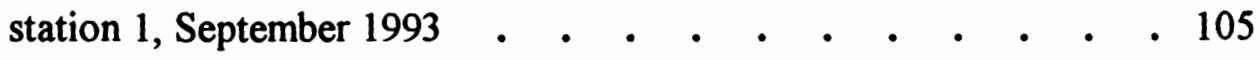


36. Oxygen and temperature profiles in Castle Lake, station 2, and light attenuation in Castle Lake, station 1, September 1993 . 106

37. Alkaline phosphatase activity in Coldwater Lake, October 1993 . . . 113

38. Oxygen, temperature, and light profiles in Coldwater Lake, station 1, March 1993 . . . . . . . . . . . . 114

39. Oxygen and temperature profiles in Coldwater Lake, station 2 and light attenuation in Coldwater Lake, station 1, March 1993 . . 115

40. Oxygen, temperature, and light profiles in Coldwater Lake, station 1, August 1993 . . . . . . . . . . . 116

41. Oxygen and temperature profiles in Coldwater Lake, station 2 and light attenuation in Coldwater Lake, station 1, August 1993 . . 117

42. Oxygen, temperature, and light profiles in Coldwater Lake, station 1, October 1993 .

43. Oxygen, temperature, and light profiles in Coldwater Lake, station 2, October 1993 .

44. Oxygen, temperature, and light profiles in Blue Lake, July $1993 \quad$ • . . 123

45. Alkaline phosphatase activity in June Lake, October 1993 . . . . 127

46. Oxygen and temperature profiles in June Lake, May 1993 . . . . . 128

47. Oxygen, temperature, and light profiles in June Lake, October $1993 \quad$ • . 130

48. Alkaline phosphatase activity in McBride Lake, October 1993 . . . 134 
49. Oxygen, temperature, and light profiles in McBride Lake, May $1993 \quad$ • 136

50. Oxygen, temperature, and light profiles in McBride Lake, August $1993 \quad$ • 137

51. Oxygen, temperature, and light profiles in McBride Lake, October $1993 \quad 138$

52. Alkaline phosphatase activity in Merrill Lake, October $1993 \quad$. . . 143

53. Oxygen, temperature, and light profiles in Merrill Lake,

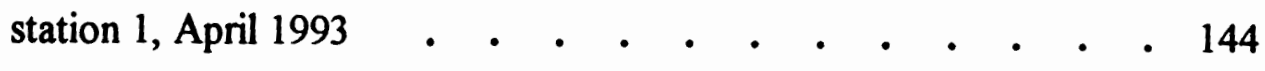

54. Oxygen and temperature profiles in Merrill Lake, station 2 and light attenuation in Merrill Lake, station 1, April $1993 \quad$ • $\quad 145$

55. Oxygen, temperature, and light profiles in Merrill Lake, station 1, August 1993 .

56. Oxygen and temperature profiles in Merrill Lake, station 2 and light attenuation in Merrill Lake, station 1, August $1993 \quad$. $\quad 147$

57. Oxygen and temperature profiles in Merrill Lake, station 1 and light attenuation in Merrill Lake, station 2, October 1993 . $\quad 148$

58. Oxygen, temperature, and light profiles in Merrill Lake, station 2 , October 1993 .

59. Chlorophyll-a concentrations as a function of DNN in nitrogen limited lakes . . . . . . . . . . 152

60. Chlorophyll-a concentrations as a function of SRP in phosphorus limited lakes 
61. DIN uptake as a function of DIN:SRP ratios in all lakes $\quad . \quad$. $\quad . \quad$. 158

62. SRP uptake as a function of DIN:SRP ratios in all lakes $\quad$ - . $\quad$ - . 159

63. Alkaline phosphatase activities as a function of SRP in multiple lakes . . 160

64. Alkaline phosphatase activities normalized to chlorophyll-a as a function of SRP in multiple lakes . . . . . . $\quad$. 162 


\section{BACKGROUND}

The most imperative task for modern aquatic scientists is the protection and restoration of fresh water. Because the demand for clean water is so great, an understanding of the factors that control water quality is fundamental to providing this essential component of life. The health of aquatic ecosystems has deteriorated in part by the process of eutrophication. When nutrients such as nitrogen or phosphorus enter an aquatic system the production of organic material within the water increases. Blooms of phytoplankton (algae) may develop causing changes in the water, adversely affecting the aquatic life and the people who use the water for drinking, irrigation, and recreation.

When aerobic bacteria consume the decaying plant material, the concentration of oxygen in the water is reduced and the environment changes from one of balance and health to one of instability and stress. All aquatic organisms save a few groups of anaerobic life forms depend upon a continual supply of oxygen to meet their metabolic needs. The decomposition of algal biomass also produces noxious tastes and smells in the water.

Another consequence of elevated rates of primary productivity is that reducing conditions are produced in the bottom sediments of lakes. The resident benthic invertebrate and fish communities may be displaced by species which tolerate low oxygen concentrations. Reducing conditions also favor the formation of toxic compounds, many of which are accumulated and magnified by the organisms which are exposed. For example, in reducing conditions, mercury ions may be methylated to methylmercury, 
which is concentrated in the tissues of fish and other consumers.

The process of eutrophication is greatly accelerated through positive feedback mechanisms initiated as the oxygen is depleted. In the absence of oxygen, additional nutrients enter the lake from the bottom sediments. Phosphorus may adsorbed to insoluble metals, such as manganese or iron, in the presence of oxygen. When the oxygen is depleted, however, these insoluble complexes become soluble (as in the reduction of ferric iron to ferrous iron) and phosphorus is liberated. The release of nutrients from the sediments can represent a significant nutrient source for the lake, stimulating additional growth and adding to the lake's oxygen demand.

Although the growth of phytoplankton is largely determined by light availability, temperature, and carbon dioxide, nutrient availability may also dictate algal growth. Consequently, management of aquatic systems often focuses on the control and reduction of nutrient input to the system. If algal growth is nutrient limited, one effective method of controlling further growth is the reduction of the appropriate nutrient(s).

Historically, nutrient limitation experiments conducted on freshwater systems indicated that phosphorus limited productivity in the majority of temperate lakes. Evidence for this was so convincing that in the late 1970 's, legislation was initiated to control the amount of phosphorus (largely in cleaning detergents) entering rivers and lakes. Although phosphorus often limits productivity in freshwater, several studies have shown nitrogen to limit algal growth. The research presented here focused on determining which nutrient(s) limit the growth of the phytoplankton in several volcanic lakes. The recent devastation of the lakes and lake basins in this area provides unusual opportunities 
to examine plankton ecology following a major disturbance.

The May 18, 1980 eruption of Mount St. Helens in southwestern Washington produced monumental changes to the landscape of this region. The dense stands of Douglas fir, Western hemlock, and Western redcedar old growth to the north of the mountain were stripped of their vegetation and blown down in swirling patterns mimicking the topography and force of the blast. The intense heat which accompanied the eruption pyrolyzed the vegetation, sending a wave of organic material onto the land and into the lakes. The eruption snapped and toppled trees $20 \mathrm{~km}$ to the north (the blast zone area), and scorched trees a few $\mathrm{km}$ further north, designated the scorch zone. Before the eruption, the lakes of this area were considered oligotrophic and pristine. Nutrient concentrations were extremely low and the waters crystal clear. The changes that were documented by researchers following the eruption revealed that the lakes were heavily impacted by the blast. Ecological processes became dominated by bacterial communities which exploited the allochthonous organic carbon from the pyrolyzed vegetation and the soluble nutrients from the ash. Chlorophyll-a concentrations were $0-1 \mu \mathrm{g} / 1$ indicating the displacement of the phytoplankton community. Heterotrophic bacteria began to decompose the woody debris in the lakes and the hypolimnetic (bottom) waters became anoxic. Production of methane was prolific and microbial nitrogen cycles dominated in some of the lakes. The extent of bacterial activity was tremendous, producing conditions usually exclusive to hyper-eutrophic lakes.

The lakes in the Mount St. Helens National Volcanic Monument provide a unique opportunity to examine nutrient limitation in the context of a more extensive lake recovery 
investigation. My hypothesis was that the planktonic communities in some of the lakes located in the blast zone were nutrient limited. Nitrogen was suspected to regulate plankton growth for several reasons. The ash and forest debris that was deposited into the lakes was relatively low in nitrogen. The $\mathrm{C}: \mathrm{N}$ ratio of Douglas fir needles is about 60 , while the more woody portions are approximately 500 . In addition, the ash from the eruption contained relatively less nitrogen compared to phosphorus. Furthermore, the nitrogen content of volcanic rock is usually relatively low (Cole 1983). Following the eruption, the scarcity of nitrogen in some of the lakes resulted in active nitrogen cycling by the microbial community. Inputs of phosphorus to the lakes from the ash may have been sufficient to convert the lakes from phosphorus limited to nitrogen limited. Several measures of nutrient limitation on multiple levels were employed to determine the presence and extent of limitation.

Findings from this research indicate that in some of the lakes the plankton are limited by nitrogen, phosphorous, or colimited by both nutrients. Various data indicate that most of the lakes have returned to pre-eruption conditions in terms of water transparency, oxygen distribution, and plankton abundance, although some of these lakes exhibit significant oxygen depletion (clinograde oxygen profiles) in the hypolimnion during periods of stratification. High concentrations of organic matter may continue to fuel bacterial decomposition of recalcitrant organic molecules. The breakdown of this material in the lakes may be regulated by oxygen availability. Many of the lakes which continue to have low concentrations of oxygen in the bottom waters are cirque in origin and have prominent amphitheater ridges to the south which protects the lakes from the wind. 
Most of these lakes are also deep, which requires stronger mixing forces (wind action) to fully circulate oxygen to the bottom during periods of turnover. The hypolimnia of some lakes have elevated values for conductivity which could indicate incomplete mixing during turnover. How quickly these lakes return to pre-eruption conditions may depend upon the decomposition of the organic material by the heterotrophic community. 


\section{INTRODUCTION}

\section{Phytoplankton Growth}

The growth of microscopic aquatic plants (phytoplankton) is controlled by several variables including light intensity, temperature, and concentrations of nutrients (primarily nitrogen and phosphorus) in the water column (Reynolds 1984). Nutrients are taken up through enzymatic pathways and incorporated into cell components, including important macromolecules such as proteins and DNA. Phytoplankton cells require certain amounts of various nutrients in order to grow and reproduce. When the nutrient supply in the surrounding environment becomes depleted, several changes may occur. Physiological responses on the cellular level may allow for more efficient use of a particular nutrient or make available nutrients that were previously unavailable. Shifts in the make-up of the phytoplankton community can also occur. Species which make more efficient use of scarce nutrients often outcompete less efficient ones and become dominant as the growing season progresses (Tilman et al. 1982).

In the 1800 's ecologists suggested that the growth of phytoplankton is determined by the amount of available substance that, when compared to what is required for balanced growth, is in shortest supply. This represents Liebig's "Law of the minimum", and marked the beginning of studies on nutrient limitation. Since then, freshwater aquatic scientists (limnologists) have used nutrient limitation to describe phytoplankton physiology and patterns of seasonal succession in the plankton community (Tilman et al. 1982). Reducing concentrations of the limiting nutrient in a lake is an excellent management tool for 
controlling algal growth and eutrophication (Wetzel 1983).

Nutrients which are most likely to limit algal growth are nitrogen, phosphorus, or in some circumstances, silicon. In the 1960's and 1970's studies on nutrient limitation revealed a strong relationship between the concentration of total phosphorus and the standing crop of phytoplankton. From this it was concluded that phosphorus was most likely the nutrient ultimately limiting phytoplankton growth in freshwater lakes (Schindler 1977). This evidence provoked legislation to regulate the use of compounds containing phosphorus, particularly in detergents, as a means to control eutrophication (Hecky and Kilham 1988). One explanation for the frequent occurrence of phosphorus limitation is that ecosystems have the ability to compensate for a limiting nutrient, particularly nitrogen (Schindler 1977). Certain prokaryotic bacteria (e.g. blue-green algae, more appropriately termed cyanobacteria) have the ability to "fix" atmospheric nitrogen into ammonium ions (a biologically available form of nitrogen), which can be used for growth and reproduction. Nitrogen fixation can represent the major source of nitrogen for phytoplankton growth (Wetzel 1983) and may explain the scarcity of nitrogen limitation in previous studies. More recent experiments have demonstrated the importance of nitrogen to phytoplankton growth and have shown it to be limiting, by itself or together with phosphorus (Elser et al. 1990; Dodds and Priscu, 1991).

Phytoplankton communities appear to violate the principle of competitive exclusion which states that two species cannot coexist if they are competing for the same resource (Petersen 1975). Studies on nutrient limitation have provided insights into the mechanisms responsible for species coexistence. First, phytoplankton communities are 
comprised of different species, each having a different nutrient uptake or storage capability. Secondly, natural systems are not at equilibrium (Tilman et al. 1982) and the distribution of nutrients is localized and patchy (Dodds et al. 1991). This allows for different species to be limited by different nutrients at the same time. Differences in nutrient uptake and growth strategies between species coupled to periodic resource availability allow for several niches to exist. In effect, the community would appear to be limited by more than one nutrient.

\section{$\underline{\text { Important Nutrients and their Sources }}$}

Several different nutrients are necessary for living organisms to survive and reproduce. Nutrients are taken up and incorporated into proteins, carbohydrates, and other essential molecules, providing the necessary machinery for life. Limnologists are interested in how nutrients get into the lake and how they are recycled among the organisms that live there. For example, ammonium is excreted by fish and zooplankton, which creates a concentrated nitrogen source for the plankton community (Liao and Lean 1978). Nutrients in the biomass of these organisms are returned to the system upon death (Dodds et al. 1991). These micro-sources of nutrients play an important role in the movement and distribution of nitrogen and phosphorus in lakes. Finally, bacteria make these nutrients available during the decomposition of organic matter, completing the cycle. 


\section{Nitrogen}

Nitrogen $(N)$ is an essential macronutrient which is assimilated into amino acids, the building blocks of enzymes and other important proteins. Nitrogen is dissolved in water primarily as elemental diatomic nitrogen $\left(\mathrm{N}_{2}\right)$, reduced ammonia $\left(\mathrm{NH}_{4}^{+}\right)$, oxidized nitrate $\left(\mathrm{NO}_{3}{ }^{-}\right)$, or nitrite $\left(\mathrm{NO}_{2}{ }^{-}\right)$. Free hydroxylamine $\left(\mathrm{NH}_{2} \mathrm{OH}\right)$ can also be used by the plankton community (Wetzel 1983). Total dissolved inorganic nitrogen (DNN) represents the dissolved nitrate + nitrite + ammonium in the water. Allochthonous sources of nitrogen for lakes include agricultural fertilizers, precipitation, and biological nitrogen fixation (by legumous terrestrial vegetation or nitrogen fixing soil bacteria in the watershed). Mineral rocks (especially volcanic basalt) are typically low in nitrogen (Downing and McCauley 1992). Autochthonous sources include nitrogen fixation by cyanobacteria and generation of nitrogen compounds from the sediments, which can be taken up directly by littoral macrophytes or used by planktonic organisms (Wetzel 1983).

Nitrogen cycles are complex and vary depending upon the conditions present. When the concentration of oxygen is sufficient to support aerobic respiration, certain groups of autotrophic bacteria and fungi can oxidize reduced nitrogen compounds (such as ammonia and amino acids) to obtain energy. This process (nitrification) is dominated largely by ammonium oxidizers, such as Nitrosomonas, which oxidize ammonium to nitrite, and Nitrobacter, which oxidize nitrite to nitrate. When oxygen concentrations are low, denitrification dominates. Here, previously oxidized nitrogen forms are reduced as a side reaction to the oxidation of organic matter. Nitrate is reduced to nitrite, which is further reduced to nitrous oxide $\left(\mathrm{N}_{2} \mathrm{O}\right)$. With a final reduction step, diatomic nitrogen 
$\left(\mathrm{N}_{2}\right)$ is produced and released as a gas (Wetzel 1983).

\section{Phosphorus}

Another macronutrient, phosphorus $(\mathrm{P})$ is an essential component of life, present in nucleic acids, phospholipids, vitamins, and phosphoproteins (Cole 1983). Phosphorus is also a key component of adenosine triphosphate (ATP), the energy currency for cells. Phosphorus can be partitioned into a soluble (dissolved) fraction or a particulate form bound to other particles. Various factors, such as bond configurations, influence whether a specific $\mathrm{P}$ compound is reactive (bioavailable) or unreactive (unavailable). The most readily available form of $\mathrm{P}$ to phytoplankton is orthophosphate, $\mathrm{PO}_{4}^{-3}$ (Wetzel 1983). Analytical methods used to measure orthophosphate often overestimate $P$ availability to the organisms because other compounds can chemically react like orthophosphate. For these reasons, the estimated orthophosphate is more correctly termed soluble reactive phosphorus (SRP). Sources of $\mathrm{P}$ include agricultural fertilizers, wastewater, precipitation, and minerals such as hydroxyapatite and volcanic ash (Cole 1983).

Cycling of $\mathbf{P}$ in the epilimnion can be extremely efficient (turnover times can be on the order of minutes) and phosphorus may be recycled several times through processes of uptake and regeneration (Dodds et al. 1991). Certain groups of phytoplankton and bacteria possess phosphatase enzymes (e.g. alkaline phosphatase) which allow the conversion of unreactive phosphate, such as polyphosphate compounds, to available orthophosphate (Boni et al. 1989). Growing phytoplankton can assimilate and store excess $\mathbf{P}$, often exceeding their immediate requirements several fold. This 'luxury' 
uptake may be enough P for many cell divisions (Reynolds 1984). Mackereth (1953) suggested that $A$ sterionella, a diatom, could store enough $\mathbf{P}$ for four full cell divisions.

Chemical conditions in lakes can influence $\mathbf{P}$ dynamics considerably. In the presence of oxygen, $\mathbf{P}$ may adsorb to oxidized ferric iron particles and precipitate, moving to the bottom. Without oxygen, reducing conditions are produced in the sediments and ferric iron becomes reduced to soluble ferrous iron, liberating $\mathrm{P}$ in the process. This process represents a significant source of $P$, creating a positive feedback loop in productive lakes (Wetzel 1983).

\section{Silicon}

Silicon ( $\mathrm{Si}$ ) is used by diatoms (Division Bacillariaceae) and yellow-brow algae (Division Crysophyceae) and comprises the protective outer structures of these phytoplankton cells (Wetzel 1983). Silicon exists in water primarily as orthosilicic acid $\left(\mathrm{Si}(\mathrm{OH})_{4}\right)$, but also occurs as polymerized silica in diatom frustules and crysophyte scales. Aluminosilicate minerals are the primary source for silicon, although volcanic ash can also contain significant amounts of $\mathrm{Si}$ (Cole 1983). The Si content $\left(\mathrm{as} \mathrm{SiO}_{2}\right)$ of the ash from the 1980 enuption of Mount St. Helens was nearly $65 \%$ (Hooper et al. 1980). Assimilation of Si in the epilimnion of lakes by diatoms (and subsequent sinking) can reduce concentrations of this nutrient in the water column. Si is recycled as herbivorous zooplankton consume and digest diatoms and recycle Si via their excretions. Furthermore, the dissolution of Si from the sediments provides an additional source of this nutrient, particularly following spring turnover. 


\section{Micronutrients}

Besides the macronutrients nitrogen, phosphorus, and silicon, several micronutrients are necessary for cells to manufacture important cell constituents. Although the concentrations of these nutrients usually exceeds nutritional requirements, these substances can also limit phytoplankton growth in special circumstances (Howarth and Cole 1985). For example, the two trace metals iron and molybdenum are found in several enzymes. The enzyme responsible for the biological fixation of molecular nitrogen (nitrogenase) contains both iron and molybdenum as essential components (Howarth and Cole 1985). Iron and manganese are necessary to produce nitrate reductase, an enzyme involved in the assimilation of nitrogen (White and Payne 1977). The process of photosynthesis is dependent upon magnesium, which is inserted into a porphyrin ring to form chlorophyll molecules (Wetzel 1983). Other essential micronutrients include sulfur, zinc, copper, boron, calcium, potassium, and vanadium. 


\section{Seasonal Distribution of Nutrients}

In addition to the patchy nature of nutrient distribution in lakes caused by phytoplankton, zooplankton, and fish excretions, nutrient availability varies seasonally in temperate lakes. In lakes that fully mix twice a year (termed dimictic) nutrients which were previously transported to the hypolimnetic (bottom) waters are brought up to the photic zone by mixing forces. As the winter ice melts, the surface waters approach maximum density (ca. $4^{\circ} \mathrm{C}$ ). The heavier water sinks and mixes with the deeper, less dense water. This process, called spring turnover, produces isothermal conditions within the lake and usually results in a homogeneous distribution of nutrients in the water column. In productive lakes with anaerobic sediments, $\mathrm{P}$ may be released from the sediments and mixed up into the water column during turnover.

As the seasons progress into summer, the increased solar radiation heats up the surface waters. Density differences between the warmed surface water and the cooler bottom water develop and the lake becomes thermally stratified. In effect the upper (epilimnetic) layer mixes independently from the bottom (hypolimnetic) water. During this time, assimilation of nutrients in the production of plankton biomass acts to reduce the concentrations of nutrients in the surface waters. Additional losses of nutrients follow as plankton sediment to the hypolimnion. This process may deplete concentrations of nutrients to levels that limit algal productivity (Sommer 1987). 


\section{Evidence for Nutrient Limitation}

Several methods have been developed to determine if the growth of the plankton is nutrient limited, particularly for nitrogen and phosphorus. Numerous short term (minutes to hours) and long term (days to weeks or longer) bioassays have been used to test nutrient deficiency. Short term bioassays provide rapid assessment of the current ecology of the entire plankton community or a portion thereof. Although short term techniques avoid container effects associated with long term incubations, they may reflect transient physiological states of the plankton community and do not always agree with long term fertilization methods (Vincent 1981; Elser et al. 1990; Dodds and Priscu 1990). Long term experiments examine the collective response of the plankton community (autotrophic and heterotrophic compartments) through measures of biomass or growth rate. Long term fertilization experiments are useful for lake managers interested in controlling eutrophication because they indicate the collective effects of nutrient enrichment at the level of the entire community. In the assessment of nutrient deficiency, a combination of methods (both short term and long term) should be used to provide multiple lines of evidence for nutrient limitation.

\section{Depletion of Nutrient Pools}

Uptake of a nutrient in the surface waters by photosynthesizing phytoplankton can deplete available nutrients to concentrations which begin to affect growth rates. Therefore, a decline in concentrations of nutrients in the photic zone occurs prior to 
physiological or community changes. Depletion of nutrient pools provides one line of evidence for nutrient limitation (Sommer 1987). Requirements for sustained algal growth vary with individual species and nutrients. When SRP concentrations are above 5-10 $\mu \mathrm{g} /$, it unlikely that P will be limiting the growth of the plankton community (Reynolds 1984). Because $\mathrm{N}$ (particularly ammonium) is quickly regenerated among the plankton, it is more difficult to indicate a specific concentration required for unlimited growth (Reynolds 1984). Silica requirements among the diatoms differ considerably between species. Small diatoms, such as Stephanodiscus astraea may dominate plankton communities when silica concentrations are less than $1 \mathrm{mg} /$. Larger diatoms, such as Asterionella formosa and Melosira gramulata have a greater requirement for silica and are more successful at higher concentrations (2-30 mg/) (Kilham 1971). These concentrations provide general guidelines to understanding phytoplankton ecology and should be applied carefully because regeneration of nutrients may sustain growth, even when concentrations are low (Reynolds 1984).

\section{Deviations from Redfield Ratios}

The relative amounts of $\mathrm{N}$ and $\mathrm{P}$ available to aquatic organisms is highly variable. Watershed characteristics (e.g. geology, land use, and vegetation) influence the ratios of $\mathrm{N}: \mathrm{P}$ in lakes. The N:P composition of aquatic organisms, however, falls within a relatively narrow range. Phytoplankton N:P mass ratios vary between 7 and 10, while zooplankton N:P ratios are usually between 7 and 9 (Downing and McCauley 1992). These mass ratios approximate the Redfield Ratio of 7.2, which is the average biomass N:P ratio for 
phytoplankton grown under nutrient sufficient conditions (Reynolds 1984). The C:N:P ratio of plankton particulate matter reflects the nutrient supply ratio available during growth, and can be used to indicate nutrient deficiency, particularly when corrections are made for non-algal particulate matter (Dodds and Priscu 1990). Likewise, the N:P supply ratio in the trophogenic zone provides information on nutrient availability and possible nutrient limitation, although cycling and regeneration can compensate for apparently low nutrient concentrations (Dodds et al. 1991).

It is important to realize that $\mathrm{N}: \mathrm{P}$ supply ratios indicate the relative proportions of each nutrient available for growth; they do not, by themselves, indicate nutrient deficiency. For example, high N:P ratios imply that if concentrations of nitrogen and phosphorus are depleted in accordance with Redfield ratios, phosphorus will be depleted prior to nitrogen. Assimilation of these nutrients may not be sufficient to reach limiting concentrations. Nevertheless, $N: P$ ratios are useful to describe relative nutrient supplies and can provide additional lines of evidence to suggest a deficiency in a particular nutrient.

The N:P supply ratio may influence the allocation of photosynthetic energy into cellular macromolecules. Groeger and Kimmel (1988) have shown that phytoplankton grown under low N:P conditions synthesize more carbohydrate and lipid and less protein. Nitrogen content of proteins is relatively high, and synthesis of these compounds decreases in favor of alternative metabolites. 


\section{Phytoplankton Community Composition}

Physical, chemical, and biological processes interact to shape the plankton community. Although several complex interactions are involved (trophic interactions, temperature, lake depth, etc.), the nutrient supply ratios often determine the phytoplankton community present. Low N:P ratios may shift the community toward nitrogen fixing species, particularly if the conditions persist for an extended period (at least one year) (Hecky and Kilham 1988; Elser et al. 1990). Elevated concentrations of phosphorus (typical of eutrophic lakes) have the effect of lowering the N:P ratio and are often dominated by cyanophytes (Downing and McCauley 1992; Sommer 1987). In the Experimental Lakes Area of the Canadian Shield, Levine (1983) found that blue-green algae became dominant at N:P molar ratios below 11. Diatoms often dominate the phytoplankton community when the silicon:SRP ratio is high, possibly due to enhanced uptake efficiency of phosphorus by diatoms, which exceeds that for green or blue-green algae (Tilman et al. 1982).

\section{Alkaline Phosphatase}

Certain groups of phytoplankton and bacteria have the ability to produce phosphatase enzymes which break organophosphate ester bonds (Boni et al. 1989). This action converts organically bound phosphorus (an unavailable form) to available orthophosphate. Alkaline phosphatase provides an important advantage during periods of low $\mathrm{P}$ concentrations because an additional source of phosphorus is created and allows further growth. Phosphatase enzyme activity is inversely proportional to SRP 
concentration and has been used as a short term bioassay to indicate the presence and degree of phosphorus limitation (Vincent 1981; Elser et al. 1990). Artificial substrates designed to mimic organic forms of phosphorus such as P-nitrophenol phosphate (PNPP) are incubated with phytoplankton cells and the absorbance of PNP is measured.

\section{Long Term Enrichment}

Long term (days to years) nutrient addition experiments have been used extensively to examine the effects of nutrient enrichment (Schindler 1977; Dodds and Priscu 1990). These methods examine the collective response of the plankton community (autotrophic and heterotrophic organisms) through measures of biomass (chlorophyll-a or ATP) or growth (carbon fixation). Long term mesocosm (container) experiments are cost effective and provide useful information to lake managers and aquatic scientists. Because long term incubations may produce conditions different than the natural environment (e.g. bacterial growth on the container walls, elevated temperatures, reduced grazing pressure by zooplankton or fish, etc.), incubation times are limited to days or weeks, depending on the size of the container used (Elser et al. 1990). Whole lake fertilizations, such as those used in the Experimental Lakes Area (Schindler 1977) are the most direct method of determining the effects of nutrient enrichment, but are limited in their use by logistical constraints. Fertilization experiments are attractive to lake managers interested in controlling eutrophication because they measure the overall response of the community, thus integrating individual responses (Elser et al. 1990).

Nutrient enrichment can stimulate uptake of non-limiting nutrients. If growth is 
limited by $P$ availability, the assimilation of $N$ will not increase unless $P$ is provided. Therefore, an increase in the uptake of a non-limiting nutrient following additions of the limiting nutrient would imply a nutrient deficiency. For example, during $\mathrm{P}$ limitation in Flathead Lake, MT, Dodds and Priscu (1990) demonstrated increased N uptake following enrichment with P. N (presumed to be non-limiting) uptake increased with the addition of the limiting nutrient $(\mathbf{P})$. For the same lake, however, limitation as determined by measures of growth following nutrient addition implicated both $\mathrm{N}$ and $\mathrm{P}$ as limiting and emphasizes the importance of using multiple methods. Fertilization experiments in which multiple nutrient treatments (e.g. $+\mathrm{N},+\mathrm{P},+\mathrm{N} \& \mathrm{P})$ are used can identify synergistic effects or colimitation by two or more nutrients (Elser et al. 1990), particularly if different levels of enrichment are used. 


\section{MATERIALS AND METHODS}

Materials and methods for field sampling and laboratory analysis are summarized below. Detailed laboratory procedures for analyses of chlorophyll-a and nutrients are presented in Appendix A. Procedures for bioassay experiments (productivity, nutrient enrichment, and alkaline phosphatase experiments) are presented in Appendix B.

\section{Field Sampling}

During 1992-93, ten lakes located within the blast zone of Mount St. Helens and four lakes located outside the blast zone were examined to evaluate the physical, chemical, and biological conditions within the lakes (Figure 1). Accessible (by truck) blast zone lakes include Fawn, Hanaford, Ryan, and Meta lakes. Boot, Panhandle, St. Helens, and Venus Lakes, located in the remote Mount Margaret area, are also inside the blast zone and required helicopter transport for sampling. Also sampled were two lakes inside the blast zone created by the 1980 eruption (Coldwater and Castle lakes). Blue, June, McBride, and Merrill lakes are located outside the blast zone and were sampled for comparison. Field sampling began in October 1992 and resumed in March 1993 when snow levels permitted access to the lakes. Bioassay experiments were conducted during temperature stratification in 1993 to determine if plankton growth was nutrient limited. 


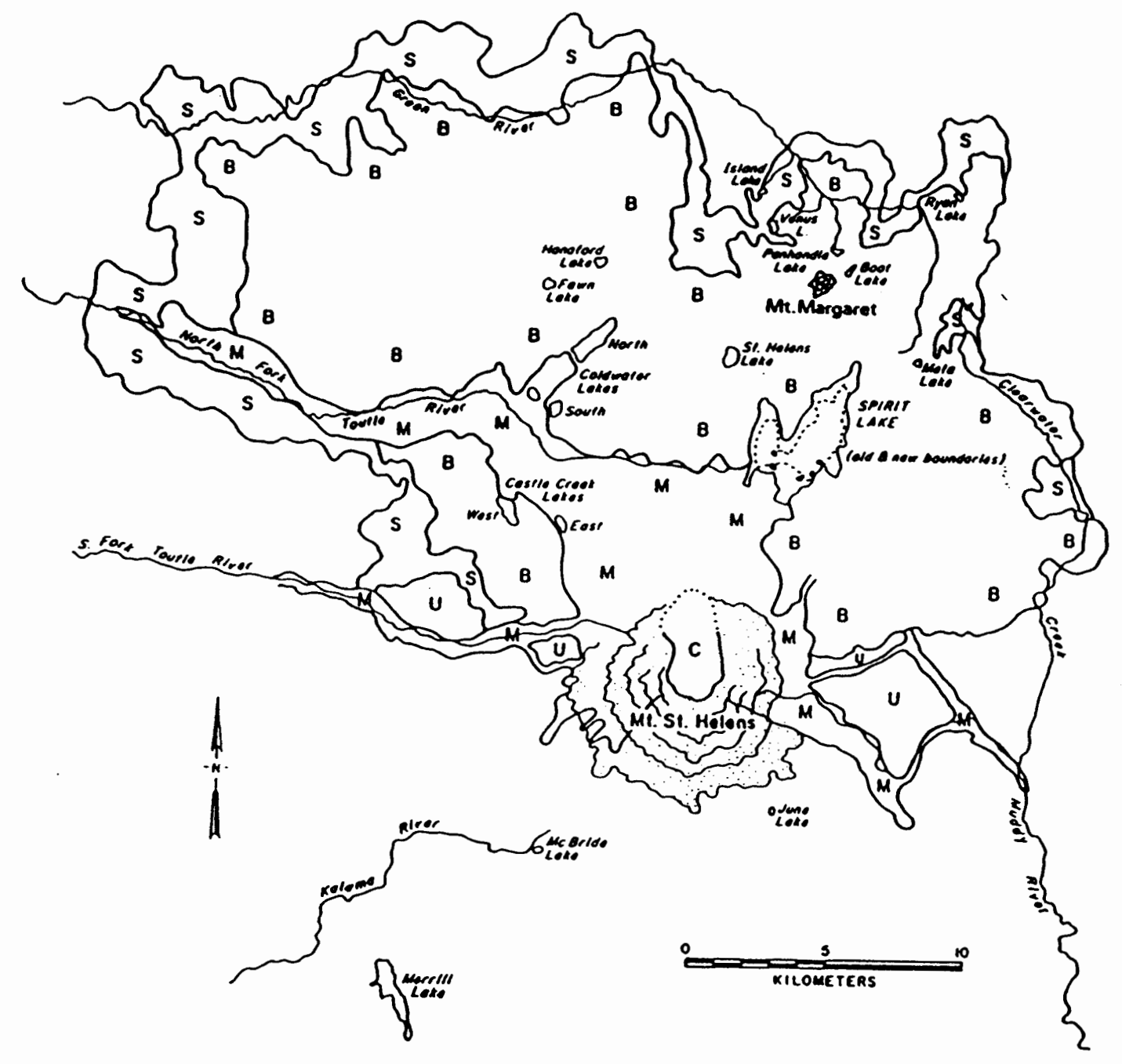

Figure 1

Map of blast deposit areas and lakes of the Mount St. Helens May 18, 1980 blast zone. Deposit areas include: $(U)=$ morphologically unaffected, light ashfall and outside blast zone; (S) = scorched, heavy deposition of volcanic debris (pumiceous lithic tephra and pyroclastic material) on the edge of the blast zone; (B) = blowdown timber, heavy deposition of volcanic debris, inside the blast zone; $(M)=$ mud, volcanic debris and pyroclastic flows inside the blast zone (from Wissmar et al. 1982a). 


\section{Water Samples}

Water samples for nutrients, chlorophyll-a, alkalinity, conductivity, and phytoplankton identification were collected using a 2.51 van Dorn type sampler and transferred to $250 \mathrm{ml}$ HDPE Nalgene sample bottles. Pseudo-replicate water samples (two samples from the same van Dorn bottle) were collected from the epilimnion (usually 1 m depth), metalimnion (depth determined from temperature profile), and hypolimnion (1 $\mathrm{m}$ off the bottom) from a station located over the maximum depth. $4 \%$ hydrochloric acid cleaned sample bottles were rinsed three times with native epilimnetic lake water before filling to the top, minimizing the amount of air in the sample bottles. Pseudo-replicate water samples were collected from three depths and analyzed for dissolved oxygen using the Winkler method (Wetzel and Likens 1991) to confirm oxygen concentrations obtained with the meter. All water samples were immediately placed on ice in the dark until further processing.

\section{Lake Profiles}

On each sampling date, profiles of temperature $\left({ }^{\circ} \mathrm{C}\right)$ and dissolved oxygen concentrations (mg/l) were measured with a YSI (Yellow Springs Instrument Co.) dissolved oxygen and temperature meter (model \# 57) which was calibrated for altitude. Measurements were taken through the water column, starting at the surface and extending to the bottom in one-meter increments. A profile of light intensity was measured through the water column on each sampling date with a spherical LI-COR light sensor interfaced to a LI-COR-1000 data logger. This meter measures photosynthetically active radiation 
(PAR) in units of $\mu$ Einsteins $\mathrm{m}^{-2} \mathrm{~s}^{-4}$. Secchi disk depths were obtained using a $20 \mathrm{~cm}$ Secchi disk, lowered from the shaded side of the boat.

\section{Bioassay Experiments}

To test for the presence of nutrient limitation, bioassay experiments were conducted on lake water (from $4 \mathrm{~m}$ depth) during summer stratification. Rates of carbon fixation and chlorophyll-a concentrations were evaluated following enrichment with $\mathrm{N}, \mathrm{P}$, or N\&P. The uptake of $N$ and $P$ from the bags was evaluated to determine if $N$ or $P$ pools were depleted during enrichment. Alkaline phosphatase activities were measured to test for $\mathbf{P}$ limitation. For a complete description of each bioassay procedure refer to Appendix A.

\section{Long Term Enrichment}

Long term bioassay experiments were conducted on waters from Fawn, Hanaford, Ryan, Castle, and Venus Lakes during summer stratification to determine if $\mathbf{N}$ or $\mathbf{P}$ was limiting the growth of the plankton communities. Replicate $(201)$ polyethylene cubitainers containing nutrient additions $(+N,+P,+N \& P)$ were incubated in situ for 4-5 days and then sampled to detect changes in rates of carbon fixation, chlorophyll-a concentrations, and nutrient concentrations. 


\section{Carbon Fixation}

Carbon fixation was determined by incubating $40 \mathrm{ml}$ subsamples from the 201 polyethylene bags with radiolabelled $\mathrm{NaH}_{2}{ }^{14} \mathrm{CO} 3$ in the near-shore area of the lake. Amounts of carbon fixed were measured using a scintillation counter.

\section{Alkaline Phosphatase}

Activity of the cell surface enzyme alkaline phosphatase was semi - quantitatively measured using the method described by Boni et al. (1989). An artificial phosphate substrate, P-nitrophenyl phosphate (PNPP), was incubated with a concentrated sample of plankton to detect enzyme activity, which was measured spectrophotometrically.

\section{Laboratory Methods}

\section{Nutrient Analysis}

Concentrations of nitrate + nitrite, ammonium, soluble reactive phosphorus, and silica were measured. Samples were filtered through acid washed $47 \mathrm{~mm}$ Millipore $\&$ type HA filters having a nominal pore size of $0.45 \mu$ using a Nalgeneß hand pump filtration unit. If filtration was not immediate, samples were placed on ice and filtered as soon as reasonably possible (always within 4 hours). Analyses of total nitrogen and total phosphorus were performed on whole water samples from some lakes. Complete descriptions of the methods for the analysis of nutrients are presented in Appendix B. 
(Nitrate + Nitrite) - Nitrogen

Concentrations of nitrate + nitrite - nitrogen were determined using the cadmium reduction method (Jones 1984).

\section{Ammonium Nitrogen}

Concentrations of ammonium nitrogen were determined using the phenol-hypochlorite method (Wetzel and Likens 1991).

\section{Total Nitrogen}

Concentrations of total nitrogen were determined after an alkaline potassium persulfate digestion using the method described by Ameel et al. (1993). This method oxidizes organic nitrogen and ammonium to nitrate. Concentrations of nitrate were then determined using the cadmium reduction method (Jones 1984).

Soluble Reactive Phosphorus

Concentrations of soluble reactive phosphorus (SRP) were determined using the ascorbic acid method (Wetzel and Likens 1991).

\section{Total Phosphorus}

Concentrations of total phosphorus were determined after alkaline potassium persulfate digestion (Ameel et al. 1993) using the ascorbic acid method (Wetzel and Likens 1991). 
$\underline{\text { Silica }}$

Concentrations of silica were determined using the molybdate method (Wetzel and Likens 1991).

Chlorophyll-a

Pheophytin-corrected chlorophyll-a analyses were performed using the Oregon Department of Environmental Quality's procedure for the analysis of chlorophyll-a, outlined in Daggett (1994).

Winkler Method for Dissolved Oxygen

Concentrations of dissolved oxygen were determined using the Winkler method (Wetzel and Likens 1991). 


\section{RESULTS AND DISCUSSION}




\section{Fawn Lake}

Fawn Lake lies in a cirque basin at an elevation of $1200 \mathrm{~m}, 15 \mathrm{~km}$ northwest of the mountain's crater. Because of its unprotected location (on the ridge above Coldwater Creek), the lake received large amounts of direct inputs from the blast, compared to other preexisting blast zone lakes. Fawn and nearby Hanaford Lakes had the highest concentrations of primary nutrients, major ions, and total alkalinities of the pre-existing blast zone lakes following the 1980 eruption of Mt. Saint Helens (Wissmar et al. 1982a). Large trees in the watershed were denuded of their vegetation and blown down. Most of the trees have been removed although scarred remnants of large trees still remain around the lake.

\section{Temperature, Oxygen, and Light}

Profiles of temperature, oxygen, and light attenuation for Fawn Lake are found in Figures 5-7. Having a maximum depth of $18 \mathrm{~m}$, Fawn Lake fully mixes twice annually (i.e. is dimictic). In October 1992 and October 1993, surface temperatures were $12^{\circ} \mathrm{C}$ and $14^{\circ} \mathrm{C}$, respectively. In 1992 , the thermocline extended from 12 to $16 \mathrm{~m}$, while in 1993 the thermocline was much larger (4 to $12 \mathrm{~m}$ ). temperatures in the hypolimnion were always near $5^{\circ} \mathrm{C}$ and the maximum surface temperature was $20^{\circ} \mathrm{C}$ (in August 1993).

In May 1993, an active population of phytoplankton located at the top of the thermocline ( $5 \mathrm{~m}$ depth) produced an oxygen surplus (positive heterograde oxygen curve). 
Oxygen concentrations reached $113 \%$ saturation (in relation to surface atmospheric pressure). A buildup of oxygen results when photosynthetic generation of oxygen exceeds respiratory oxygen demand. In the upper hypolimnion, oxygen levels fell slightly, but never below $90 \%$ saturation. During all samplings, Fawn Lake exhibited a decline in the concentrations of oxygen in the lower hypolimnion (a clinograde oxygen curve). Late in summer, concentrations dropped to $1 \mathrm{mg} / \mathrm{l}$, indicating reducing conditions in the bottom sediments.

Water transparency in Fawn Lake is high. During both years, the average extinction coefficient was $0.34 \mathrm{~m}^{-1}$ (range $0.28-0.38 \mathrm{~m}^{-1}$ ) and Secchi disk depths ranged from $6.5 \mathrm{~m}$ to $7.7 \mathrm{~m}$. The depth of $1 \%$ light intensity varied between 12 and $16 \mathrm{~m}$ during this study. These data indicate oligotrophic conditions in Fawn Lake, although the oxygen depletion in the hypolimnion suggests a more productive classification.

\section{Nutrient Dynamics}

Concentrations of total and dissolved nutrients, chlorophyll-a and nutrient ratios for Fawn Lake are found in Tables 1-3. During three samplings in 1993, the average soluble reactive phosphorous (SRP) concentration was $5 \mu \mathrm{g} /$ (range $0.8 \mu \mathrm{g} / 1-14.8 \mu \mathrm{g} / \mathrm{l}$ ). The average nitrate + nitrite concentration was $13.8 \mu \mathrm{g} /$ (range $5.0-62.3 \mu \mathrm{g} /$ ), while ammonium concentrations averaged $11.3 \mu \mathrm{g} / 1$ (range $2.8-41.4 \mu \mathrm{g} / \mathrm{l}$ ).

During summer months, concentrations of DIN and SRP were reduced in the photic zone ( 0 - $15 \mathrm{~m}$ depth). Maximum depletion of DIN and SRP occurred at the depth of maximum chlorophyll-a concentration $(26.9 \mu \mathrm{g} / 1$ at $10 \mathrm{~m})$, suggesting nutrient 
assimilation and growth by the phytoplankton community. From May to August 1993, the concentration of SRP in the metalimnion declined from 12.3 to $2.2 \mu \mathrm{g} / \mathrm{l}$. Nitrate + nitrite concentrations also declined at this time from 12.0 to $5.0 \mu \mathrm{g} /$, as did ammonium (from 10.5 to $2.8 \mu \mathrm{g} / \mathrm{l})$. The uptake and assimilation of DNN and SRP by photosynthesizing phytoplankton may be responsible for the depletion of these nutrients to possibly limiting concentrations.

From August to October 1993, the concentration of SRP had increased in the hypolimnion from 1.6 to $6.1 \mu \mathrm{g} / 1$. In moderately productive lakes with anaerobic sediments, P may be released from bottom sediments and circulated into the water column during circulation. The additional $\mathrm{P}$ from the sediments can stimulate autotrophic and heterotrophic productivity in the upper strata in the spring when solar radiation melts the ice and provides sufficient energy for photosynthesis. Diatoms, which can better tolerate these low temperatures, often form blooms at this time (Sommer et al. 1986).

As the growing season progressed into October 1993, oxygen concentrations in the hypolimnion declined further, and ammonium concentrations increased to $41.4 \mu \mathrm{g} /$, while nitrate + nitrite decreased to $13.1 \mu \mathrm{g} /$. Anoxic conditions in the hypolimnion would favor reduced nitrogen (ammonium) over oxidized nitrogen, (nitrate). At this time, the concentration of SRP also increased from 1.6 to $6.1 \mu \mathrm{g} /$ in the hypolimnion. It is interesting to note that the highest chlorophyll-a concentration for Fawn Lake $(40.1 \mu \mathrm{g} / \mathrm{l})$ occurred during this period of abundant ammonium and SRP in the hypolimnion, suggesting colimitation by both $\mathrm{N}$ and $\mathrm{P}$. 
Concentrations of Si remained high throughout the year, and was always above 6.7 mg/. The percent Si content (as $\mathrm{SiO}_{2}$ ) of the ash from the 1980 eruption of Mount $\mathrm{St}$. Helens was nearly 65\% (Hooper et al. 1980) and represents a large supply of this nutrient. In 1993, the dominant phytoplankton species in Fawn Lake was Cyclotella comta, a small diatom (Baker 1995). In August 1993, concentrations of Si were lowest in the epilimnion (6.7 $\mathrm{mg} /$ ) and increased with increasing depth (up to $7.8 \mathrm{mg} / \mathrm{l})$. This may reflect the dissolution of $\mathrm{Si}$ from the bottom sediments or assimilation of $\mathrm{Si}$ and subsequent sedimentation of diatom frustrules to the bottom. Silica requirements among the diatoms differ considerably between species. Small diatoms, such as Stephanodiscus astraea may dominate plankton communities when silica concentrations are less than $1 \mathrm{mg} /$. Larger diatoms, such as Asterionella formosa and Melosira gramulata have a greater requirement for silica and are more successful at higher concentrations (2-30 mg/1) (Kilham 1971). Because Si is so plentiful in Fawn Lake, it is doubtful that the plankton are deficient in this nutrient.

\section{Nutrient Ratios}

DIN:SRP ratios provide estimates of nutrient availability for plankton growth. Since balanced growth requires both $\mathrm{N}$ and $\mathrm{P}$, ratios of available nutrients are often used to determine which nutrient will be depleted first. N:P mass-ratios greater than 10 have been suggested to indicate $P$ limitation, while ratios less than 4.5 suggest $N$ as the limiting nutrient (Groeger and Kimmel 1988).

DIN:SRP ratios for Fawn Lake during 1993 differ both seasonally and with depth. 
DIN:SRP ratios were low at all depths (always below 2.1) in May 1993, although concentrations of $\mathrm{N}$ and $\mathrm{P}$ would be sufficient to support unlimited growth. In August, however, the DIN:SRP ratio was 4.6 in the metalimnion, where the chlorophyll-a concentration was the highest $(40.1 \mu \mathrm{g} / \mathrm{l})$. This value closely approaches the critical value of 4.5, suggesting $N$ limitation, although the SRP concentration of $2.2 \mu \mathrm{g} / \mathrm{l}$ provides evidence for the possible colimitation by $\mathrm{N}$ and $\mathrm{P}$. By October, increased concentrations of SRP throughout the water column resulted in lowered DIN:SRP ratios, which averaged 2.9 .

Nutrient ratios using total $\mathrm{N}(\mathrm{TN})$ and total $\mathrm{P}$ (TP) can be useful to indicate nutrient limitation, although these measures can be biased because the majority of total $\mathrm{N}$ and $\mathrm{P}$ is tied up in plankton biomass, and does not necessarily represent what is available for growth. Despite this, TN:TP mass ratios $<14$ have been used to identify limitation by N (Downing and McCauley 1992). During this study the average TN:TP ratio was 3 in Fawn Lake and suggest $\mathrm{N}$ limitation. 
Bioassays

Alkaline Phosphatase

Data on alkaline

phosphatase enzyme activity

(APA) during August 1993

suggest that the plankton

community in Fawn Lake is $P$

deficient (Figure 2). Plankton

collected from $4 \mathrm{~m}$ depth

produced a $38 \%$ average (SD

6) increase in APA,

compared to control blanks.

\section{Alkaline Phosphatase Activity}

Fawn Lake August 1993

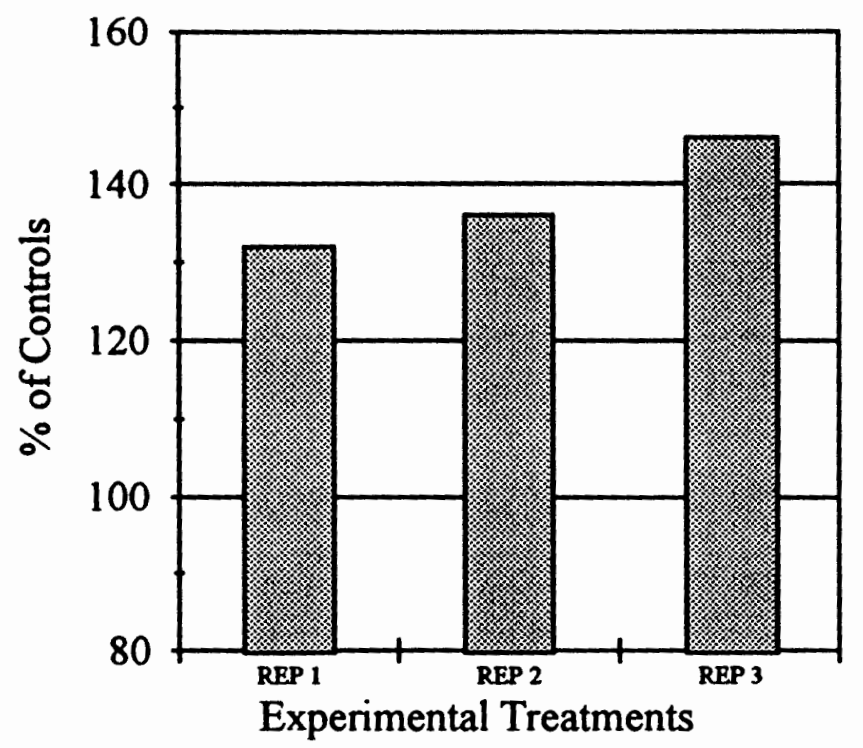

Figure 2

While APA provides an additional source of $P$ to the plankton, it costs the cells energy to manufacture and activate the enzyme. Therefore, unless further growth is constrained by low SRP concentrations, it is energetically unfavorable to express and activate this enzyme. Increased APA is often observed during P limiting conditions and activity of the enzyme has been inversely correlated with concentrations of SRP (Boni et al. 1989). The APA in Fawn Lake confirms the relative shortage of phosphorus and suggests limitation by this nutrient. 


\section{Long Term Enrichment}

Various measures of plankton activity (chlorophyll-a production and carbon fixation) following nutrient addition suggests that the phytoplankton and heterotrophic organisms (e.g. bacteria) in

Fawn Lake respond differently to enrichment.

Fertilization experiments using 201 polyethylene bags (cubitainers) indicate that both $\mathrm{N}$ and $\mathrm{P}$ limit the productivity (growth) of the plankton community in the lake.

\section{Chlorophyll-a}

concentrations only increased

when $\mathrm{N}$ was added $(+\mathrm{N}$ and

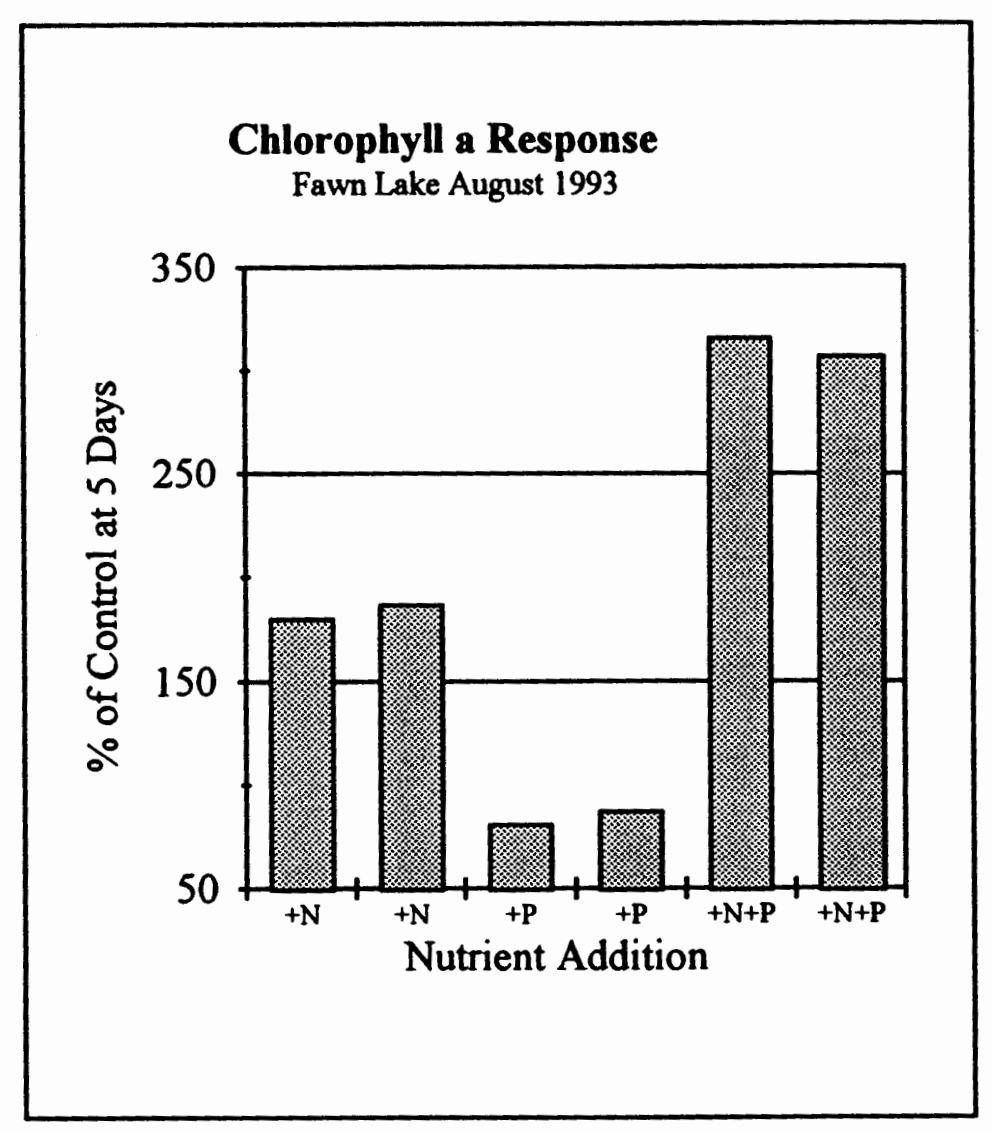

Figure 3

+N\&P), while $\mathrm{P}$ produced no

response (Figure 3). The chlorophyll-a response $(+\mathrm{N}=180 \%$ and $+\mathrm{N} \& \mathrm{P}=300 \%)$

compared to controls, indicates a synergistic relationship between $N$ and $P$. Two way analysis of variance (ANOVA) indicates a significant increase in chlorophyll-a with the addition of $N(P=0.002)$ and $N \& P(P \leq 0.001)$. Phosphorus additions produced no significant response. These data suggest primary limitation of pigment production by $\mathrm{N}$. 
Further, the addition of $70 \mu \mathrm{g} / \mathrm{N}$ was enough to remove the $\mathrm{N}$ limitation, evidenced by increased chlorophyll-a production with the addition of N\&P.

Carbon fixation in replicate bags given $\mathrm{N}+\mathrm{P}$ increased $370 \%$ compared to controls, while no increase occurred when $\mathrm{N}$ or $\mathrm{P}$ was added by itself (Figure 4). Two way analysis of variance (ANOVA) indicates a significant response with the simultaneous addition of $\mathrm{N}$ and $\mathrm{P}$ ( $\mathrm{P} \quad 0.001)$, but not with $\mathrm{N}$ or $\mathrm{P}$ alone.

The addition of $\mathbf{P}$ caused a decrease in the concentration of $\mathrm{N}$ inside the bags (compared to controls), which provides evidence for $P$ limitation. If $\mathbf{P}$ was limiting, the addition of this nutrient would allow further

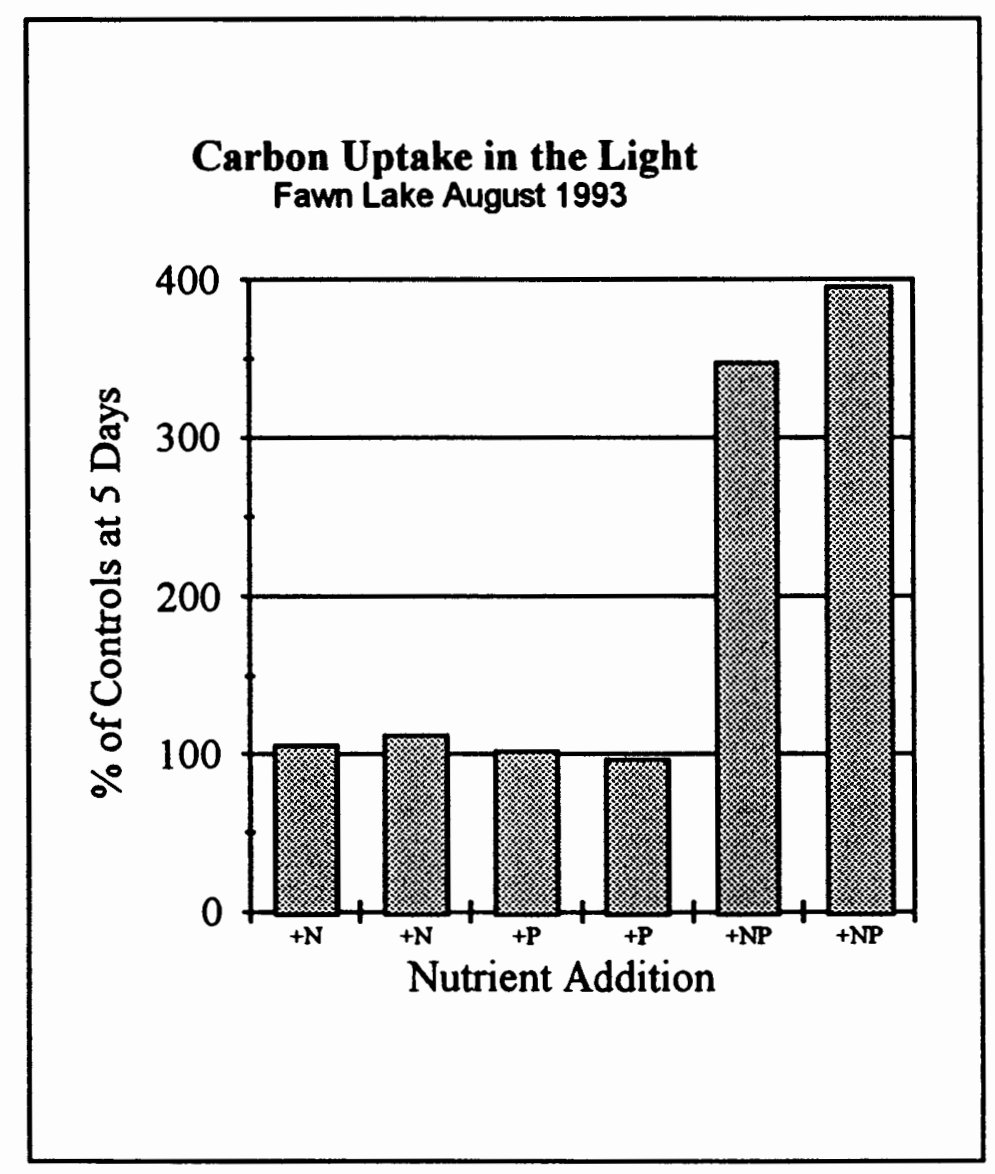

Figure 4 growth, which would require additional $\mathrm{N}$ uptake. Concentrations of chlorophyll-a or carbon fixation did not increase, however, with the addition of $\mathrm{P}$, suggesting assimilation of $\mathrm{N}$ into products other than photosynthetic pigments. Depending on the environmental conditions, carbon fixation may be associated with pigment production (as in chlorophyll-a), or the formation of other 
biological molecules such as carbohydrates and lipids (Groeger and Kimmel 1988). It is possible that chemolithotrophic ammonium oxidizing bacteria (e.g. Nitrosomonas and Nitrobacter generas) may be responsible for the decrease of ammonium inside the bags. These bacteria are capable of extracting energy during the oxidation of ammonium to nitrite and nitrate. Following the 1980 eruption, bacteria were the primary component of the plankton community in these lakes, with $\mathrm{N}$ fixation, nitrification, and denitrification processes dominating $\mathrm{N}$ cycles (Baross et al. 1982). Bacteria compete with algae for nutrients and certainly play an important role in lake ecosystems. Although bacterial metabolism was not examined in this investigation, future studies on plankton growth in these lakes should include bacterial counts.

APA was evaluated following nutrient addition to determine if treatments receiving $P$ relieved limitation by this nutrient, which should have decreased APA. Compared to controls, APA decreased $58 \%$ with the addition of $\mathrm{P}$, indicating that $\mathrm{P}$ was no longer in short supply. APA did not increase with the addition of $N$, implying that APA was maximal in the controls and that more time would be needed for AP synthesis before additional activity would be detected.

\section{Conclusion}

Several approaches to nutrient limitation in Fawn Lake portray a complicated, dynamic picture. Carbon fixation and chlorophyll-a significantly increased with the simultaneous addition of $\mathrm{N}$ and $\mathrm{P}$, suggesting co-limitation by these nutrients. Together with evidence from alkaline phosphatase activity and nutrient concentrations and ratios, 
the bioassays implicate both $\mathrm{N}$ and $\mathrm{P}$ as limiting plankton growth in the lake. Chlorophylla data suggest that $\mathrm{N}$ may be the primary limiting nutrient of the phytoplankton. The importance of the non-photosynthetic plankton (e.g. bacteria and other heterotrophs) has not been evaluated but probably influence nutrient dynamics appreciably. 
Table 1. Nutrient Concentrations and Ratios and Chlorophyll a Concentrations in Fawn Lake (5-22-93). Values \pm 1 standard deviation.

\begin{tabular}{|c|c|c|c|c|c|c|c|c|c|c|}
\hline $\begin{array}{l}\text { Depth } \\
\text { (m) }\end{array}$ & $\begin{array}{l}\text { Chl. a } \\
(\mu g /)\end{array}$ & $\begin{array}{c}\text { SRP } \\
(\mu \mathrm{g} /)\end{array}$ & $\underset{(\mu \mathrm{g} /)}{\mathrm{TP}}$ & $\begin{array}{c}\mathrm{NO}_{3}+\mathrm{NO}_{2} \\
(\mu \mathrm{g} /)\end{array}$ & $\begin{array}{l}\mathrm{NH}_{4} \\
(\mu \mathrm{g} /)\end{array}$ & $\begin{array}{c}\text { TN } \\
(\mu g /)\end{array}$ & $\begin{array}{l}\mathrm{SiO}_{2} \\
(\mathrm{mg} / \mathrm{l})\end{array}$ & $\mathrm{SRN}^{3}: \mathrm{SRP}$ & SRN $N^{3}: T P$ & TN:TP \\
\hline 1 & $\begin{array}{l}10.4 \\
\pm 2.3\end{array}$ & $\begin{array}{l}12.1 \\
\pm 0.6\end{array}$ & N.D. ${ }^{2}$ & $\begin{array}{l}16.1^{1} \\
\pm 9.4\end{array}$ & $\begin{array}{l}10.5 \\
\pm 3.5\end{array}$ & N.D. ${ }^{2}$ & $\begin{array}{l}6.8 \\
\pm 0\end{array}$ & $2.1^{i}$ & N.D. ${ }^{2}$ & N.D. ${ }^{2}$ \\
\hline 10 & $\begin{array}{l}45.8^{1} \\
\pm 11.9\end{array}$ & $\begin{array}{l}12.3 \\
\pm 0.4\end{array}$ & N.D. ${ }^{2}$ & $\begin{array}{l}12.0 \\
\pm 0.2\end{array}$ & $\begin{array}{c}6.0 \\
\pm 0.2\end{array}$ & N.D. ${ }^{2}$ & $\begin{array}{l}6.8 \\
\pm 0\end{array}$ & 1.5 & N.D. ${ }^{2}$ & N.D. ${ }^{2}$ \\
\hline 18 & $\begin{array}{r}41.3^{1} \\
\pm 24.4\end{array}$ & $\begin{array}{l}14.8 \\
\pm 0.4\end{array}$ & N.D. ${ }^{2}$ & $\begin{array}{l}18.1 \\
\pm 0.1\end{array}$ & $\begin{array}{c}9.9 \\
\pm 0.7\end{array}$ & N.D. ${ }^{2}$ & $\begin{array}{l}6.9 \\
\pm 0\end{array}$ & 1.9 & N.D. ${ }^{2}$ & N.D. ${ }^{2}$ \\
\hline
\end{tabular}

${ }_{1}^{1}$ Questionable data (standard deviation $>(\text { value })^{1 / 2}$ ) ${ }^{2}$ N.D. No data ${ }^{3} \mathrm{SRN}=\mathrm{NO}_{3}+\mathrm{NO}_{2}+\mathrm{NH}_{4}$

Figure 5. Profiles of Temperature, Oxygen, and Light Attenuation in Fawn Lake (5-22-93).
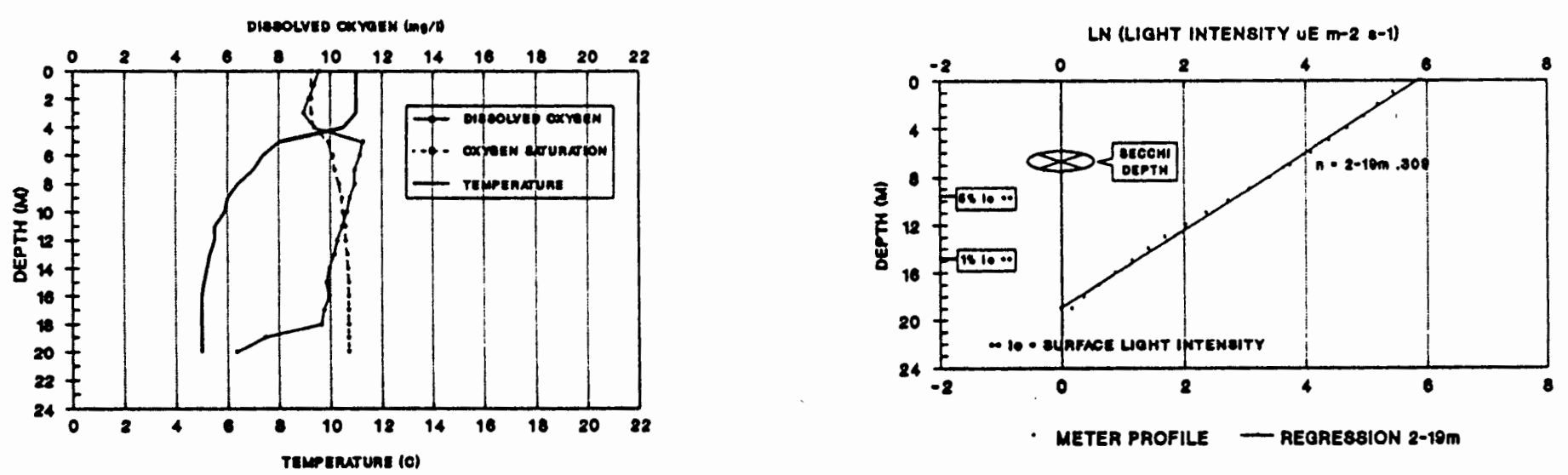
Table 2. Nutrient Concentrations and Ratios and Chlorophyll a Concentrations in Fawn Lake (8-5-93). Values \pm 1 standard deviation.

\begin{tabular}{|c|c|c|c|c|c|c|c|c|c|c|}
\hline $\begin{array}{l}\text { Depth } \\
\text { (m) }\end{array}$ & $\begin{array}{l}\text { Chl. } \mathrm{g} \\
(\mu \mathrm{g} / \mathrm{l})\end{array}$ & $\begin{array}{c}\text { SRP } \\
(\mu g /)\end{array}$ & $\underset{(\mu \mathrm{g} /)}{\mathrm{TP}}$ & $\begin{array}{c}\mathrm{NO}_{3}+\mathrm{NO}_{2} \\
(\mu g / 1)\end{array}$ & $\begin{array}{l}\mathrm{NH}_{4} \\
(\mu \mathrm{g} /)\end{array}$ & $\begin{array}{c}\text { TN } \\
(\mu g /)\end{array}$ & $\begin{array}{l}\mathrm{SiO}_{2} \\
(\mathrm{mg} /)\end{array}$ & $\mathrm{SRN}^{3}: \mathrm{SRP}$ & $S R N^{3}: T P$ & TN:TP \\
\hline 1 & 8.3 & $\begin{array}{l}0.8 \\
\pm 0\end{array}$ & N.D. ${ }^{2}$ & $\begin{array}{l}10.7 \\
\pm 0.5\end{array}$ & $\begin{array}{c}2.8 \\
\pm 0.1\end{array}$ & N.D. ${ }^{2}$ & $\begin{array}{c}6.7 \\
\pm 0.1\end{array}$ & 16.0 & N.D. ${ }^{2}$ & N.D. ${ }^{2}$ \\
\hline 10 & 26.9 & $\begin{array}{c}2.2 \\
\pm 0.2\end{array}$ & N.D. ${ }^{2}$ & $\begin{array}{c}5.0^{1} \\
\pm 4.8\end{array}$ & $\begin{array}{c}5.6 \\
\pm 0.5\end{array}$ & N.D. ${ }^{2}$ & $\begin{array}{l}6.9 \\
\pm 0\end{array}$ & $4.6^{1}$ & N.D. ${ }^{2}$ & N.D. ${ }^{2}$ \\
\hline 18 & $9.7^{1}$ & $\begin{array}{c}1.6 \\
\pm 0.2\end{array}$ & N.D. ${ }^{2}$ & $62.3^{1}$ & $\begin{array}{c}9.4 \\
\pm 1.6\end{array}$ & N.D. ${ }^{2}$ & $\begin{array}{c}7.8 \\
\pm 0.1\end{array}$ & $23.6^{1}$ & N.D. ${ }^{2}$ & N.D. ${ }^{2}$ \\
\hline
\end{tabular}

${ }^{1}$ Questionable data (standard deviation $>(\text { value })^{1 / 2}$ ) ${ }^{2} \mathrm{~N} . \mathrm{D}$. No data ${ }^{3} \mathrm{SRN}=\mathrm{NO}_{3}+\mathrm{NO}_{2}+\mathrm{NH}_{4}$

Figure 6. Profiles of Temperature, Oxygen, and Light Attenuation in Fawn Lake (8-5-93).
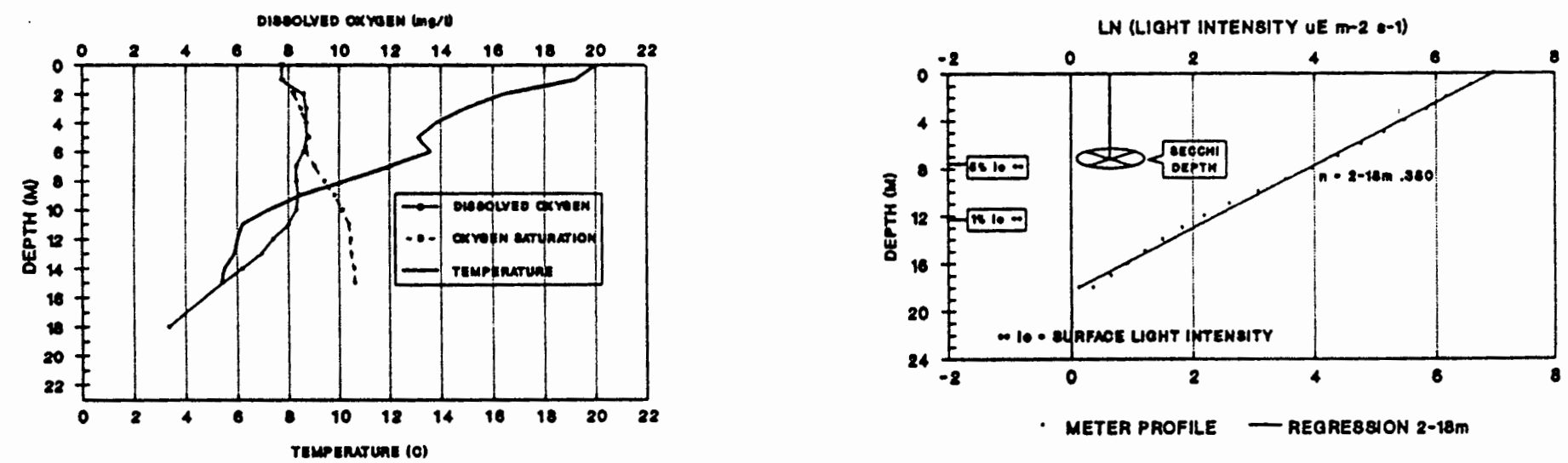
Table 3. Nutrient Concentrations and Ratios and Chlorophyll a Concentrations in Fawn Lake (10-22-93). Values \pm 1 standard deviation.

\begin{tabular}{|c|c|c|c|c|c|c|c|c|c|c|}
\hline $\begin{array}{l}\text { Depth } \\
\text { (m) }\end{array}$ & $\begin{array}{l}\text { Chl. a } \\
(\mu g / 1)\end{array}$ & $\begin{array}{c}\text { SRP } \\
(\mu g /)\end{array}$ & $\underset{(\mu \mathrm{g} /)}{\mathrm{TP}}$ & $\begin{array}{c}\mathrm{NO}_{3}+\mathrm{NO}_{2} \\
(\mu \mathrm{g} /)\end{array}$ & $\begin{array}{l}\mathrm{NH}_{4} \\
(\mu \mathrm{g} /)\end{array}$ & $\begin{array}{c}\text { TN } \\
(\mu g /)\end{array}$ & $\begin{array}{l}\mathrm{SiO}_{2} \\
(\mathrm{mg} / \mathrm{l})\end{array}$ & SRN'SRP & $S R N^{3}: T P$ & TN:TP \\
\hline 1 & $\begin{array}{l}38.5^{1} \\
\pm 12.9\end{array}$ & $\begin{array}{c}5.9 \\
\pm 0.3\end{array}$ & $\begin{array}{l}16.8 \\
\pm 0.5\end{array}$ & $\begin{array}{c}7.0 \\
\pm 0.4\end{array}$ & $\begin{array}{c}9.2 \\
\pm 0.8\end{array}$ & $\begin{array}{l}59.6^{1} \\
\pm 7.9\end{array}$ & $\begin{array}{c}7.1 \\
\pm 0.2\end{array}$ & 2.8 & 1.0 & $3.5^{1}$ \\
\hline 10 & $\begin{array}{l}10.5 \\
\pm 3.1\end{array}$ & $\begin{array}{c}4.8 \\
\pm 0.2\end{array}$ & $\begin{array}{l}17.3 \\
\pm 1.8\end{array}$ & $\begin{array}{r}6.7^{1} \\
\pm 2.8\end{array}$ & $\begin{array}{c}7.9 \\
\pm 0.6\end{array}$ & $\begin{array}{l}45.1 \\
\pm 1.3\end{array}$ & $\begin{array}{l}7.5 \\
\pm 0\end{array}$ & $3.0^{1}$ & $0.9^{1}$ & 2.6 \\
\hline 18 & $\begin{array}{l}40.1^{1} \\
\pm 7.0\end{array}$ & $\begin{array}{c}6.1 \\
\pm 0.5\end{array}$ & $\begin{array}{l}18.8 \\
\pm 0\end{array}$ & $\begin{array}{l}13.1^{1} \\
\pm 5.3\end{array}$ & $\begin{array}{l}41.4 \\
\pm 0.5\end{array}$ & $\begin{array}{l}49.9^{1} \\
\pm 8.2\end{array}$ & $\begin{array}{c}9.3 \\
\pm 0.1\end{array}$ & $9.1^{2}$ & $2.9^{1}$ & $2.6^{1}$ \\
\hline
\end{tabular}

${ }^{1}$ Questionable data (standard deviation $>\left(\right.$ value) ${ }^{1 / 2}$ ) ${ }^{2} \mathrm{~N} . \mathrm{D}$. No data ${ }^{3} \mathrm{SRN}=\mathrm{NO}_{3}+\mathrm{NO}_{2}+\mathrm{NH}_{4}$

Figure 7. Profiles of Temperature, Oxygen, and Light Attenuation in Fawn Lake (10-22-93).
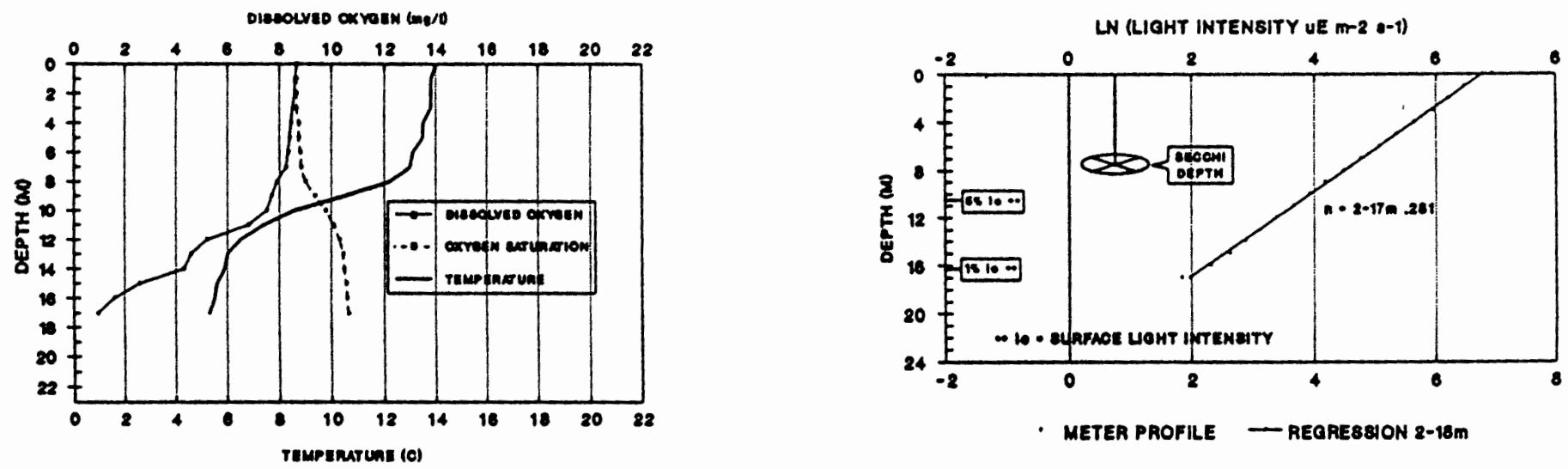


\section{Hanaford Lake}

Hanaford Lake lies in a cirque basin at an elevation of $1260 \mathrm{~m}, 14 \mathrm{~km}$ northwest of the mountain's crater. Because of its exposed location (on the ridge above Coldwater Creek), the lake received large amounts of direct inputs from the blast, compared to other preexisting blast zone lakes. Hanaford and nearby Fawn Lakes had the highest concentrations of primary nutrients, major ions, and total alkalinities following the 1980 eruption of Mount Saint Helens (Wissmar et al. 1982a). Large trees in the watershed were denuded of their vegetation and blown down. Most of the trees have been removed although scarred remnants of large trees still remain around the lake.

\section{Temperature, Oxygen, and Light}

Profiles of temperature, oxygen, and light attenuation for Hanaford Lake are found in Figures 11-13. Having a maximum depth of $16 \mathrm{~m}$, Hanaford Lake fully mixes twice annually (i.e. is dimictic). In May 1993 , surface temperatures reached $11^{\circ} \mathrm{C}$ and the thermocline extended from 3 to $9 \mathrm{~m}$. Temperatures in the hypolimnion were near $5^{\circ} \mathrm{C}$. By August 1993, a continuous thermocline penetrated from 3 to $12 \mathrm{~m}$ and bottom temperatures were $9^{\circ} \mathrm{C}$. Maximum surface temperatures were $19^{\circ} \mathrm{C}$ in August of 1993 .

Profiles of dissolved oxygen taken during 1992 and 1993 indicate nearly saturated (with respect to surface atmospheric pressure) conditions in the water column. In August 1993, concentrations of oxygen were slightly elevated at $11 \mathrm{~m}$ (106\% saturation), suggesting phytoplankton photosynthesis. Oxygen concentrations were reduced in the 
hypolimnion in 1992 and 1993 when concentrations were $7 \mathrm{mg} / \mathrm{l}$ (minimum of $4.5 \mathrm{mg} / \mathrm{lin}$ October 1992). These conditions suggest a persistent oxygen demand in the bottom sediments.

Water transparency in Hanaford Lake is high. During both years, the average extinction coefficient was $0.24 \mathrm{~m}^{-1}$ (range $0.16-0.32 \mathrm{~m}^{-1}$ ) and Secchi disk depths ranged from $9 \mathrm{~m}$ to $13.5 \mathrm{~m}$. One percent surface light intensity was present throughout the water column during all samplings. These conditions are typical of oligotrophic lakes.

\section{Nutrient Dynamics}

Concentrations of total and dissolved nutrients, chlorophyll-a and nutrient ratios for Hanaford Lake are found in Tables 4-6. During three samplings in 1993, the average soluble reactive phosphorous (SRP) concentration was $6.4 \mu \mathrm{g} /$ (range $1-10.7 \mu \mathrm{g} / \mathrm{l})$. The average nitrate + nitrite concentration was $28.8 \mu \mathrm{g} / 1($ range $4.7-110 \mu \mathrm{g} / \mathrm{l})$ while ammonium concentrations averaged $6.1 \mu \mathrm{g} / \mathrm{l}$ (range $2.3-15.6 \mu \mathrm{g} / \mathrm{l}$ ).

During summer months, minimum concentrations of DN and SRP were found in the photic zone (0 - $10 \mathrm{~m}$ depth). Maximum depletion of SRP occurred during August 1993, when chlorophyll-a was also at its annual maximum $(40 \mu \mathrm{g} / \mathrm{l})$ throughout the water column. The lack of distinct stratification in the lake precludes the development of discrete density layers. This facilitates the vertical transport of nutrients and biomass in the lake. From May to August 1993, the concentration of SRP in the upper strata (0 - 10 m) declined from 10 to $1.5 \mu \mathrm{g} /$. Nitrate + nitrite concentrations also declined from 25 to $10 \mu \mathrm{g} / 1$. Ammonium concentrations remained fairly constant, in response to the 
consistently high oxygen concentrations in the lake. The uptake and assimilation of DIN and SRP by photosynthesizing phytoplankton depletes these nutrients to possibly limiting concentrations.

The concentration of DIN remained fairly constant $(14 \mu \mathrm{g} / 1)$ into October 1993 , although the nitrate + nitrite:ammonium ratio shifted in favor of ammonium. As the growing season progressed, oxygen concentrations in the hypolimnion declined, and ammonium concentrations increased to $15.6 \mu \mathrm{g} /$, while nitrate + nitrite decreased to 5.4 $\mu \mathrm{g} /$. Concentrations of SRP also increased throughout the water column up to $6 \mu \mathrm{g} /$, possibly from sediment releases.

Concentrations of Si remained high throughout the year, never falling below 4.4 mg/. In 1993, the dominant phytoplankton species in Hanaford Lake was Cryptomonas erosa and the Chrysophyte Kephyrion (Baker 1995). Because Si is so plentiful in Hanaford Lake, it is not likely that this nutrient would limit the growth of these phytoplankton.

\section{Nutrient Ratios}

DIN:SRP ratios for Hanaford lake varied seasonally during 1993. In May 1993, the DNN:SRP ratio was 2.8 in the epilimnion and metalimnion, although sufficient concentrations of both $\mathrm{N}$ and $\mathrm{P}$ would preclude limitation by either nutrient at this time. In August 1993, however, the DIN:SRP ratios were high (15.4 and 9.6 in the epilimnion and metalimnion, respectively). These ratios suggest limitation by $\mathrm{P}$, which was in short supply $(1-2 \mu \mathrm{g} /)$. Simultaneous depletion of DIN to $10 \mu \mathrm{g} / \mathrm{l}$ provides evidence for the 
possible colimitation by both $\mathrm{N}$ and $\mathrm{P}$ in Hanaford Lake. By October 1993, the increase in SRP throughout the water column resulted in DIN:SRP ratios averaging 2.4 .

The average TN:TP ratio was 4.6 in Hanaford Lake, further implicating $\mathrm{N}$ as limiting.

Bioassays

Alkaline Phosphatase

Data on alkaline

phosphatase enzyme activity

(APA) during August 1993

suggest that the plankton

community in Hanaford Lake

is $\mathbf{P}$ deficient (Figure 8).

Plankton collected from $4 \mathrm{~m}$

depth produced a $45 \%$

average (SD 7.1) increase in

APA, compared to control

blanks. These data suggest a

shortage of $\mathrm{P}$ in Hanaford

Alkaline Phosphatase Activity

Hanaford Lake August 1993

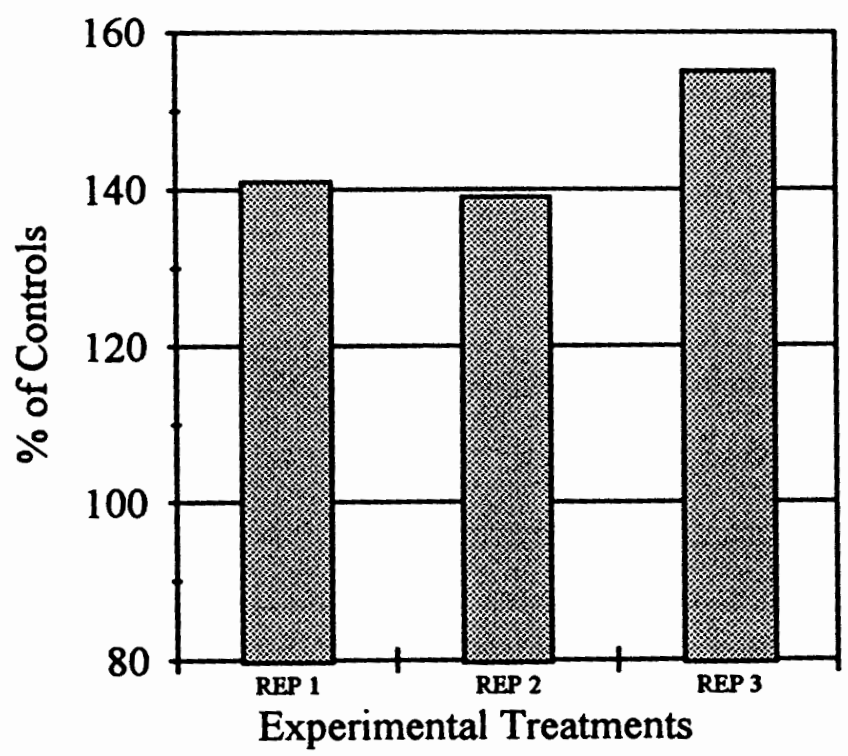

Lake.

Figure 8 
Long Term Enrichments

Fertilization

experiments using 201

polyethylene bags indicate

that both $\mathrm{N}$ and $\mathrm{P}$ limit the

productivity (growth) of the

plankton community in

Hanaford Lake. Carbon

fixation in replicate bags given

N\&P increased $370 \%$

compared to controls, while

no increase occurred when $\mathrm{N}$

or $\mathbf{P}$ was added by itself

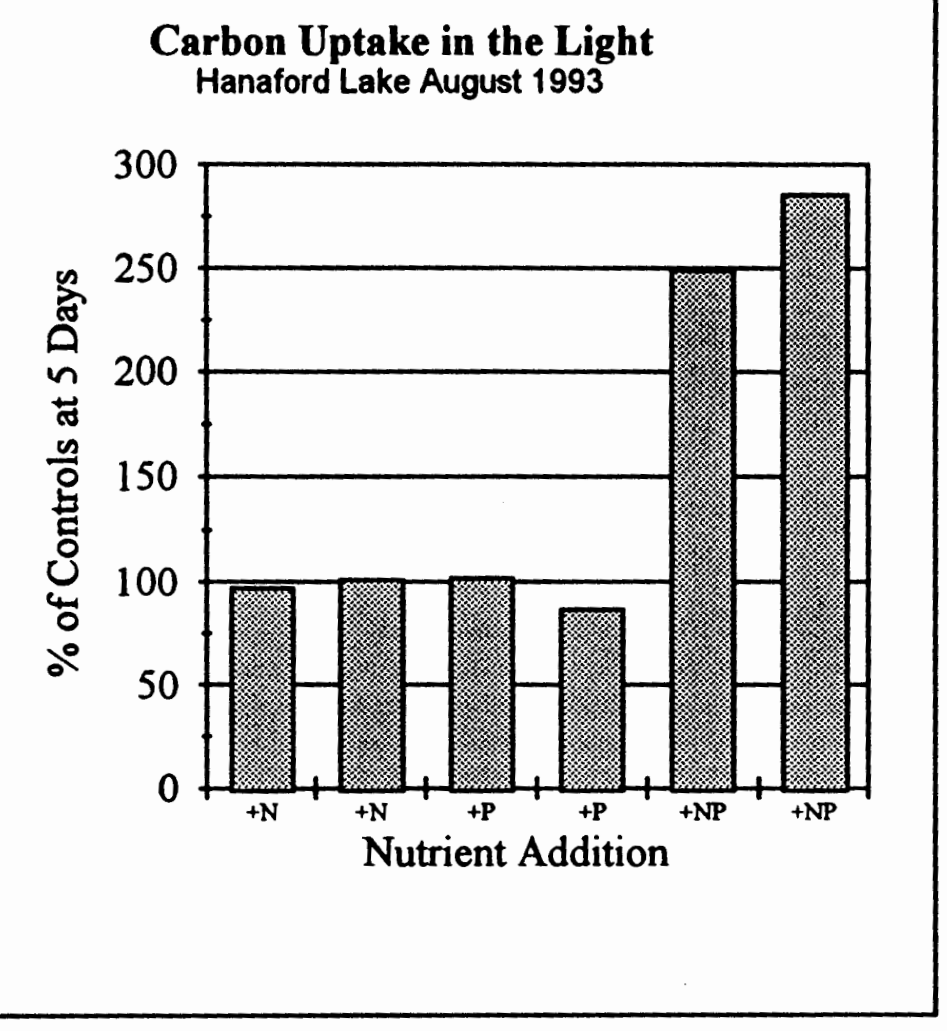

Figure 9

(Figure 9). Two way analysis

of variance (ANOVA) indicates a significant response with the simultaneous addition of N\&P ( $P$ 0.001) but not when $\mathrm{N}$ or $\mathrm{P}$ alone was added. The addition of $\mathrm{P}$ caused a decrease in the concentration of ammonium from 14.9 to $3.1 \mu \mathrm{g} /$ inside the bags (compared to controls), which provides evidence for $\mathrm{P}$ limitation. If $\mathrm{P}$ was limiting, the addition of this nutrient would allow further growth, which would require additional $\mathrm{N}$ uptake. Also, bags given N\&P showed decreased concentrations of ammonium compared to bags given $\mathrm{N}$ alone. This would occur only if $\mathrm{P}$ allowed for additional uptake and assimilation of $\mathrm{N}$. Additions of $\mathrm{N}$ did not produce any decrease in $\mathrm{P}$, although SRP data 
was variable. Chlorophyll-a data was highly variable and showed no consistent pattern.

Plankton APA was

evaluated following nutrient

addition to evaluate two

hypotheses. First, if

treatments receiving $\mathbf{P}$

relieved limitation by this

nutrient, then the APA

should decrease. Secondly,

APA would be expected to

increase if $\mathrm{N}$ additions

promoted further growth,

thus intensifying the

requirement for $\mathrm{P}$. APA
Alkaline Phosphatase Activity

Hanaford Lake August 1993

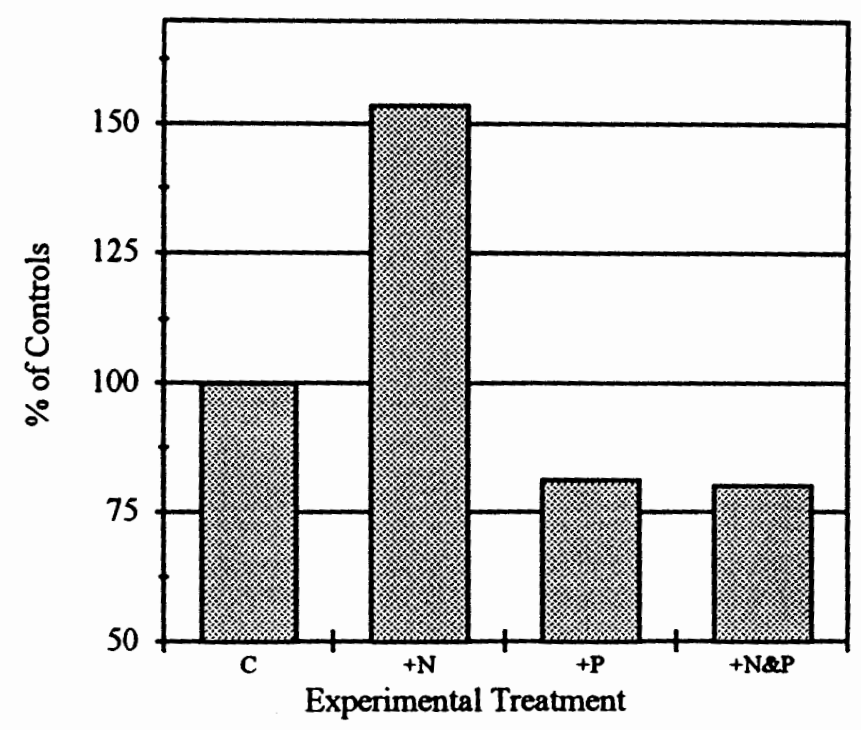

Figure 10

did decrease with $\mathrm{P}$ additions, either alone or in combination with $\mathrm{N}$ as expected (Figure 10). APA increased with the addition of $N$, confirming the second hypothesis. Since APA could be induced to increase (with the addition of $\mathrm{N}$ ), and activity was not maximal, the extent of P limitation may have been only minor. The SRP liberated through the action of the enzyme may have been enough to compensate for the $\mathbf{P}$ deficiency. This also indicates that there is a fine line between limitation by $\mathrm{N}$ and $\mathrm{P}$ in Hanaford Lake. Additions of $\mathrm{N}$ did induce a physiological response (increased APA) and energy was channeled into making more phosphatase enzyme instead of other cell components. 
Conclusion

There is evidence that the plankton in Hanaford Lake is limited by both $\mathrm{N}$ and $\mathrm{P}$, although concentrations of $N$ in the lake suggest that $P$ is the primary limiting nutrient. Carbon fixation only increased with the simultaneous addition of N\&P, while no stimulation was found with additions of $\mathrm{N}$ or $\mathrm{P}$ alone. Alkaline phosphatase activity clearly shows $\mathrm{P}$ limitation, although additions of $\mathrm{N}$ do increase APA, indicating submaximal APA. The importance of the non-photosynthetic component of the plankton in the lake is yet to be determined. 
Table 4. Nutrient Concentrations and Ratios and Chlorophyll a Concentrations in Hanaford Lake (5-22-93). Values \pm 1 standard deviation.

\begin{tabular}{|c|c|c|c|c|c|c|c|c|c|c|}
\hline $\begin{array}{l}\text { Depth } \\
\text { (m) }\end{array}$ & $\begin{array}{l}\text { Chl. a } \\
(\mu g /)\end{array}$ & $\begin{array}{l}\text { SRP } \\
(\mu \& \Omega)\end{array}$ & $\underset{(\mu \mathrm{g} / 1)}{\mathrm{TP}}$ & $\begin{array}{c}\mathrm{NO}_{3}+\mathrm{NO}_{2} \\
(\mu \mathrm{g} /)\end{array}$ & $\begin{array}{l}\mathrm{NH}_{4} \\
(\mu g /)\end{array}$ & $\begin{array}{c}\text { TN } \\
(\mu \mathrm{g} / 1)\end{array}$ & $\begin{array}{l}\mathrm{SiO}_{2} \\
(\mathrm{mg} / \mathrm{l})\end{array}$ & SRN'SRP & SRN & IN:TP \\
\hline 1 & $\begin{array}{l}32.9^{1} \\
+6.1\end{array}$ & $\begin{array}{l}10.7 \\
\pm 0\end{array}$ & N.D. ${ }^{2}$ & $\begin{array}{l}27.8 \\
\pm 3.4\end{array}$ & $\begin{array}{c}2.9 \\
\pm 0.1\end{array}$ & N.D. ${ }^{2}$ & $\begin{array}{l}6.1 \\
\pm 0\end{array}$ & 2.9 & N.D. ${ }^{2}$ & N.D. ${ }^{2}$ \\
\hline 8 & $\begin{array}{l}12.5 \\
\pm 0.3\end{array}$ & $\begin{array}{c}9.3 \\
\pm 0.3\end{array}$ & N.D. ${ }^{2}$ & $\begin{array}{l}21.6^{1} \\
\pm 4.8\end{array}$ & $\begin{array}{c}4.5 \\
\pm 0.6\end{array}$ & N.D. ${ }^{2}$ & $\begin{array}{l}5.7 \\
\pm 0\end{array}$ & $2.8^{1}$ & N.D. ${ }^{2}$ & N.D. ${ }^{2}$ \\
\hline 14 & $\begin{array}{l}29.0 \\
\pm 3.2\end{array}$ & $\begin{array}{c}9.2 \\
\pm 0.4\end{array}$ & N.D. ${ }^{2}$ & $\begin{array}{l}60.4^{1} \\
\pm 45.8\end{array}$ & $\begin{array}{c}5.2 \\
\pm 1.3\end{array}$ & N.D. ${ }^{2}$ & $\begin{array}{l}5.5 \\
\pm 0\end{array}$ & $6.9^{1}$ & N.D. ${ }^{2}$ & N.D. ${ }^{2}$ \\
\hline
\end{tabular}

Questionable data (standard deviation $>\left(\right.$ value) ${ }^{1 / 2}$ ) ${ }^{2} \mathrm{~N} . \mathrm{D}$. No data ${ }^{3} \mathrm{SRN}=\mathrm{NO}_{3}+\mathrm{NO}_{2}+\mathrm{NH}_{4}$

Figure 11. Profiles of Temperature, Oxygen, and Light Attenuation in Hanaford Lake (5-22-93).
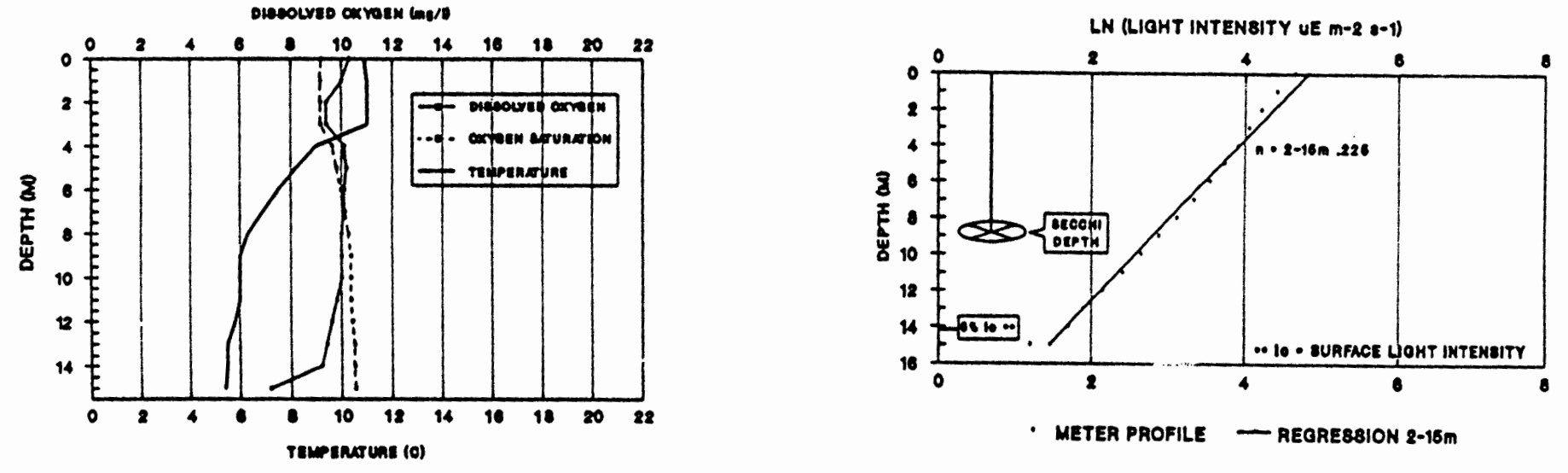
Table 5. Nutrient Concentrations and Ratios and Chlorophyll a Concentrations in Hanaford Lake (8-5-93). Values \pm 1 standard deviation.

\begin{tabular}{|c|c|c|c|c|c|c|c|c|c|c|}
\hline $\begin{array}{l}\text { Depth } \\
\text { (m) }\end{array}$ & $\begin{array}{l}\text { Chl. } \mathrm{A} \\
(\mu \mathrm{g} / \mathrm{l})\end{array}$ & $\begin{array}{c}\text { SRP } \\
(\mu g / 1)\end{array}$ & $\begin{array}{c}\text { TP } \\
(\mu g / 1)\end{array}$ & $\begin{array}{c}\mathrm{NO}_{3}+\mathrm{NO}_{2} \\
(\mu \mathrm{g} /)\end{array}$ & $\begin{array}{l}\mathrm{NH}_{4} \\
(\mu \mathrm{g} / 1)\end{array}$ & $\begin{array}{c}\text { TN } \\
(\mu g / \mathcal{I})\end{array}$ & $\begin{array}{l}\mathrm{SiO}_{2} \\
(\mathrm{mg} / \mathrm{l})\end{array}$ & $S R N^{3}: S R P$ & $S R N^{3}: T P$ & TN:TP \\
\hline 1 & 38.0 & $\begin{array}{c}1.0 \\
\pm 0.2\end{array}$ & N.D. ${ }^{2}$ & $\begin{array}{l}11.9 \\
\pm 0.2\end{array}$ & $\begin{array}{c}3.1 \\
\pm 0.1\end{array}$ & N.D. ${ }^{2}$ & $\begin{array}{l}6.0 \\
\pm 0\end{array}$ & 15.4 & N.D. ${ }^{2}$ & N.D. ${ }^{2}$ \\
\hline 10 & 40.1 & $\begin{array}{l}1.5 \\
\pm 0\end{array}$ & N.D. ${ }^{2}$ & $\begin{array}{l}10.6^{1} \\
\pm 3.5\end{array}$ & $\begin{array}{c}3.4 \\
\pm 0.4\end{array}$ & N.D. ${ }^{2}$ & $\begin{array}{l}5.6 \\
\pm 0\end{array}$ & $9.6^{2}$ & N.D. ${ }^{2}$ & N.D. ${ }^{2}$ \\
\hline 14 & 46.5 & $\begin{array}{l}6.7^{1} \\
\pm 5.5\end{array}$ & N.D. ${ }^{2}$ & $\begin{array}{l}110.4^{1} \\
\pm 93.4\end{array}$ & 2.3 & N.D. ${ }^{2}$ & $\begin{array}{c}4.4 \\
\pm 0.1\end{array}$ & $91.3^{1}$ & N.D. ${ }^{2}$ & N.D. ${ }^{2}$ \\
\hline
\end{tabular}

\section{${ }^{1}$ Questionable data (standard deviation $>\left(\right.$ value) ${ }^{1 / 2}$ ) ${ }^{2}$ N.D. No data ${ }^{3} \mathrm{SRN}=\mathrm{NO}_{3}+\mathrm{NO}_{2}+\mathrm{NH}_{4}$}

Figure 12. Profiles of Temperature, Oxygen, and Light Attenuation in Hanaford Lake (8-5-93).
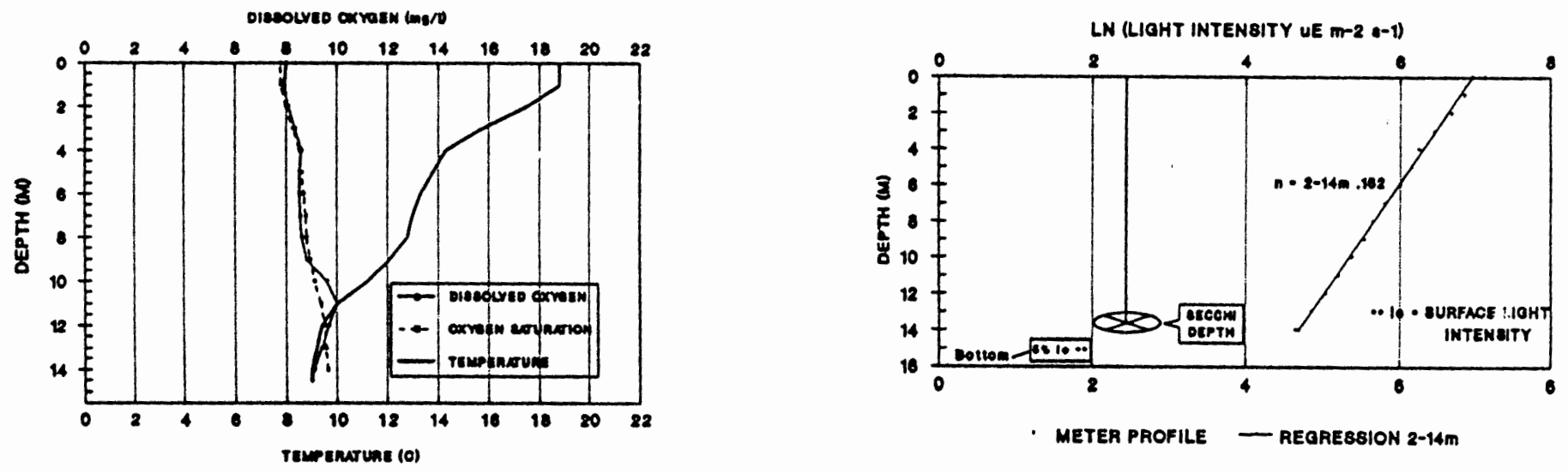
Table 6. Nutrient Concentrations and Ratios and Chlorophyll a Concentrations in Hanaford Lake (10-22-93). Values \pm 1 standard deviation.

\begin{tabular}{|c|c|c|c|c|c|c|c|c|c|c|}
\hline $\begin{array}{l}\text { Depth } \\
\text { (m) }\end{array}$ & $\begin{array}{l}\text { Chl. a } \\
(\mu \mathrm{g} /)\end{array}$ & $\begin{array}{c}\text { SRP } \\
(\mu g /)\end{array}$ & $\begin{array}{c}\text { TP } \\
(\mu g / 1)\end{array}$ & $\begin{array}{c}\mathrm{NO}_{3}+\mathrm{NO}_{2} \\
(\mu \mathrm{g} /)\end{array}$ & $\begin{array}{l}\mathrm{NH}_{4} \\
(\mu g / 1)\end{array}$ & $\underset{(\mu \mathcal{I} /)}{\mathrm{TN}}$ & $\begin{array}{l}\mathrm{SiO}_{2} \\
(\mathrm{mg} /)\end{array}$ & $S R N^{3}: S R P$ & $S R N^{3}: T P$ & TN:TP \\
\hline 1 & $\begin{array}{l}24.7^{1} \\
\pm 5.6\end{array}$ & $\begin{array}{c}6.4 \\
\pm 0.2\end{array}$ & $\begin{array}{l}12.3 \\
\pm 2.4\end{array}$ & $\begin{array}{c}6.4 \\
\pm 0.4\end{array}$ & $\begin{array}{c}7.5 \\
\pm 0.6\end{array}$ & $\begin{array}{l}43.6 \\
\pm 1.7\end{array}$ & $\begin{array}{l}6.3 \\
\pm 0\end{array}$ & 2.2 & 1.2 & 3.7 \\
\hline 8 & $\begin{array}{l}20.5 \\
\pm 4.0\end{array}$ & $\begin{array}{l}6.2 \\
\pm 0\end{array}$ & $\begin{array}{l}15.9 \\
\pm 0\end{array}$ & $\begin{array}{c}5.4 \\
\pm 0.1\end{array}$ & $\begin{array}{l}15.6 \\
\pm 4.1\end{array}$ & $\begin{array}{l}70.8 \\
\pm 2.9\end{array}$ & $\begin{array}{c}7.7 \\
\pm 0.1\end{array}$ & 3.4 & 1.3 & 4.5 \\
\hline 13 & $\begin{array}{r}19.2 \\
\pm 3.9\end{array}$ & $\begin{array}{l}6.8 \\
\pm 0\end{array}$ & $\begin{array}{l}17.3 \\
\pm 0.2\end{array}$ & $\begin{array}{c}4.7 \\
\pm 0.1\end{array}$ & $\begin{array}{l}7.0 \\
\pm 0.1\end{array}$ & $\begin{array}{l}96.3^{1} \\
\pm 33.4\end{array}$ & $\begin{array}{c}5.0 \\
\pm 0.8\end{array}$ & 1.7 & 0.7 & $5.6^{2}$ \\
\hline
\end{tabular}

${ }^{1}$ Questionable data (standard deviation $>(\text { value })^{1 / 2}$ ) ${ }^{2}$ N.D. No data ${ }^{3} \mathrm{SRN}=\mathrm{NO}_{3}+\mathrm{NO}_{2}+\mathrm{NH}_{4}$

Figure 13. Profiles of Temperature, Oxygen, and Light Attenuation in Hanaford Lake (10-22-93).
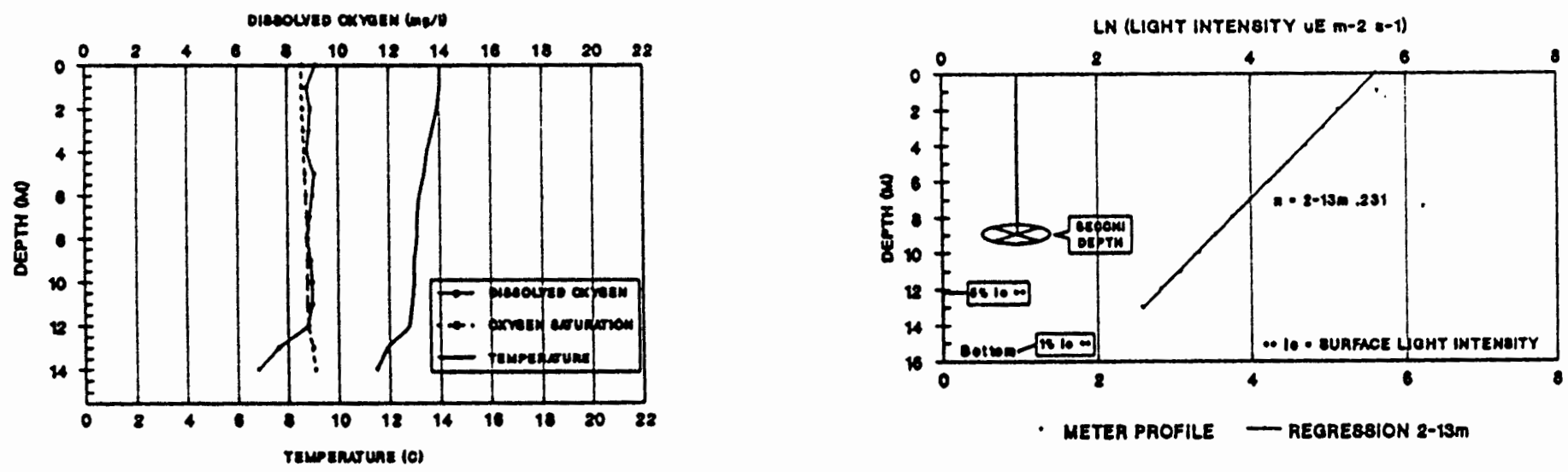


\section{Meta Lake}

Meta Lake lies in a cirque basin at an elevation of $(1097) \mathrm{m}, 13 \mathrm{~km}$ northeast of the mountain's crater. The lake is located near the eastern edge of the blast zone and numerous trees to the north were scorched but left standing after the eruption. Because the lake was frozen over at the time of the eruption, populations of brook trout and amphibians survived the 1980 enuption. The cirque amphitheater to the south also afforded the lake some protection from the blast which traveled down the Green River valley, to the west of Meta Lake, extending $19 \mathrm{~km}$ to the north. Beavers had been active at the lake in past years, altering lake water levels, but they appear to have moved on. Highly successful populations of amphibians and trout continue to thrive in the lake.

\section{Temperature, Oxygen, and Light}

Profiles of temperature, oxygen, and light attenuation for Meta Lake are found in Figures 15-17. Having a maximum depth of $8 \mathrm{~m}$, Meta Lake fully mixes twice annually (i.e. is dimictic). Because of its relatively shallow depth and small volume, water temperatures in the lake were slightly elevated during this study. Surface temperatures ranged from $12-15^{\circ} \mathrm{C}$, while bottom temperatures were always greater than $8^{\circ} \mathrm{C}$. In June and August 1993, the lake was stratified with respect to temperature, when thermoclines developed from $5 \mathrm{~m}$ to the bottom.

In August and September 1993, oxygen was elevated at 5 and $3 \mathrm{~m}$, respectively (oxygen concentrations reached $108 \%$ and $115 \%$ saturation. A positive heterograde 
oxygen curve suggests photosynthetic activity at these depths.

Oxygen concentrations one-half meter off the bottom in June and August 1993 were 1.8 and $0.3 \mathrm{mg} /$, respectively. These values correspond to $16 \%$ and $3 \%$ saturation with respect to surface atmospheric pressure. By October 1993, the lake was nearly isothermal $\left(12^{\circ} \mathrm{C}\right)$, although the lake was anoxic $(0 \mathrm{mg} / \mathrm{l})$ one-half meter off the bottom. These data indicate that reducing conditions were present in the bottom sediments.

Water transparency in Meta Lake is limited. In 1993, the average extinction coefficient was $0.90 \mathrm{~m}^{-1}$ (range $0.47-1.5 \mathrm{~m}^{-1}$ ) and Secchi disk depths were fairly constant, averaging $4.8 \mathrm{~m}$. Profiles of light intensity reveal a dramatic increase in light attenuation below $6 \mathrm{~m}$. In August and October 1993, the average extinction coefficient was $0.48 \mathrm{~m}^{-1}$ above $6 \mathrm{~m}$ and $1.3 \mathrm{~m}^{-1}$ below $6 \mathrm{~m}$. Some chemical or biological entity is attenuating the light in the lower half of the lake. The cause of this decreased transparency has not yet been identified. The depth of $1 \%$ light intensity varied between 5.6 and $6.7 \mathrm{~m}$ during this study. Moderate water transparency and periodic anaerobic conditions in the hypolimnion suggest mesotrophic conditions in Meta Lake.

\section{Nutrient Dynamics}

Concentrations of total and dissolved nutrients, chlorophyll-a and nutrient ratios for Meta Lake are found in Tables 8-10. During three samplings in 1993, the SRP concentrations were low, averaging $2.3 \mu \mathrm{g} /$ (range 1.7-2.7 $\mu \mathrm{g} /$ ). The average nitrate + nitrite concentration was $9.0 \mu \mathrm{g} /$ (range $0.8-35.4 \mu \mathrm{g} / \mathrm{l}$ ) and ammonium concentrations averaged $6.9 \mu \mathrm{g} / \mathrm{l}($ range $0.2-16.3 \mu \mathrm{g} / \mathrm{l})$. 
Concentrations of SRP were consistently low in Meta Lake, showing little variation with season or depth. During all three sampling, SRP concentrations only varied between 1.7 and $2.7 \mu \mathrm{g} /$, while concentrations of DIN showed considerable seasonal variation. DIN decreased from near $40 \mu \mathrm{g} /$ in June to $3 \mu \mathrm{g} /$ in August 1993. Both nitrate + nitrite and ammonium concentrations declined during this time, although nitrate + nitrite concentrations showed the largest decline. The SRP concentration did not decline during this time, suggesting rapid $\mathrm{P}$ regeneration. These data suggest colimitation by $\mathrm{N}$ and $\mathrm{P}$.

Concentrations of SRP and ammonium were consistently higher in the hypolimnion, reflecting the reducing conditions present in the bottom sediments. As the growing season progressed into October 1993, oxygen concentrations in the hypolimnion declined further, and ammonium concentrations increased to $16.3 \mu \mathrm{g} / 1$, while the nitrate + nitrite concentration decreased to $2.3 \mu \mathrm{g} /$. Anoxic conditions in the hypolimnion would favor reduced nitrogen (ammonium) over oxidized nitrogen (nitrate). It is interesting to note that the highest chlorophyll-a concentration for Meta Lake in $1993(80.2 \mu \mathrm{g} / 1)$ occurred during this period of abundant ammonium in the hypolimnion.

Concentrations of $\mathrm{Si}$ remained high throughout the year, and were always above $8.2 \mathrm{mg} /$. In 1993 the dominant phytoplankton species in Meta Lake were Cryptomonas erosa, Oocystis pusilla, and the large diatom Asterionella formosa (Baker 1995). During all samplings, concentrations of silica increased with increasing depth reflecting the dissolution of $\mathrm{Si}$ from the bottom sediments, or the assimilation and subsequent sedimentation of $\mathrm{Si}$ in diatom frustrules to the bottom. Because $\mathrm{Si}$ is so plentiful in Meta 
Lake, it is doubtful that this nutrient would limit the growth of silicious phytoplankton.

Concentrations of chlorophyll-a and TN and TP were always higher near the bottom of the lake. The largest TP and TN concentrations were found in the hypolimnion in August 1993 when TP and TN concentrations were 42.6 and $193.8 \mu \mathrm{g} /$, respectively. These data suggest a phytoplankton community was present in the deeper waters of the lake.

\section{Nutrient Ratios}

DIN:SRP ratios for Meta Lake during 1993 varied seasonally. Since SRP concentrations were fairly constant through the sampling period, DIN:SRP ratios were controlled by concentrations of DIN. DIN:SRP ratios were high in June 1993 (above 10), reflecting the abundant concentrations of nitrate + nitrite, while decreased DIN in August resulted in low DIN:SRP ratios (near 1). These ratios indicate that the onset of $\mathrm{N}$ limitation began late in the season when $\mathrm{N}$ was depleted from the water column. During this study the average TN:TP ratio was 4.0 and were always less than 6.2 , indicating $N$ limiting conditions. 
Bioassays

\section{Alkaline Phosphatase}

Data on alkaline

phosphatase enzyme activity (APA) during October 1993 suggest that the plankton community in Meta Lake is P deficient (Figure 14).

Plankton collected from $4 \mathrm{~m}$ depth produced a $44 \%$ average (SD 2.6) increase in APA compared to blank controls. This suggests that $\mathbf{P}$ was in short supply in the

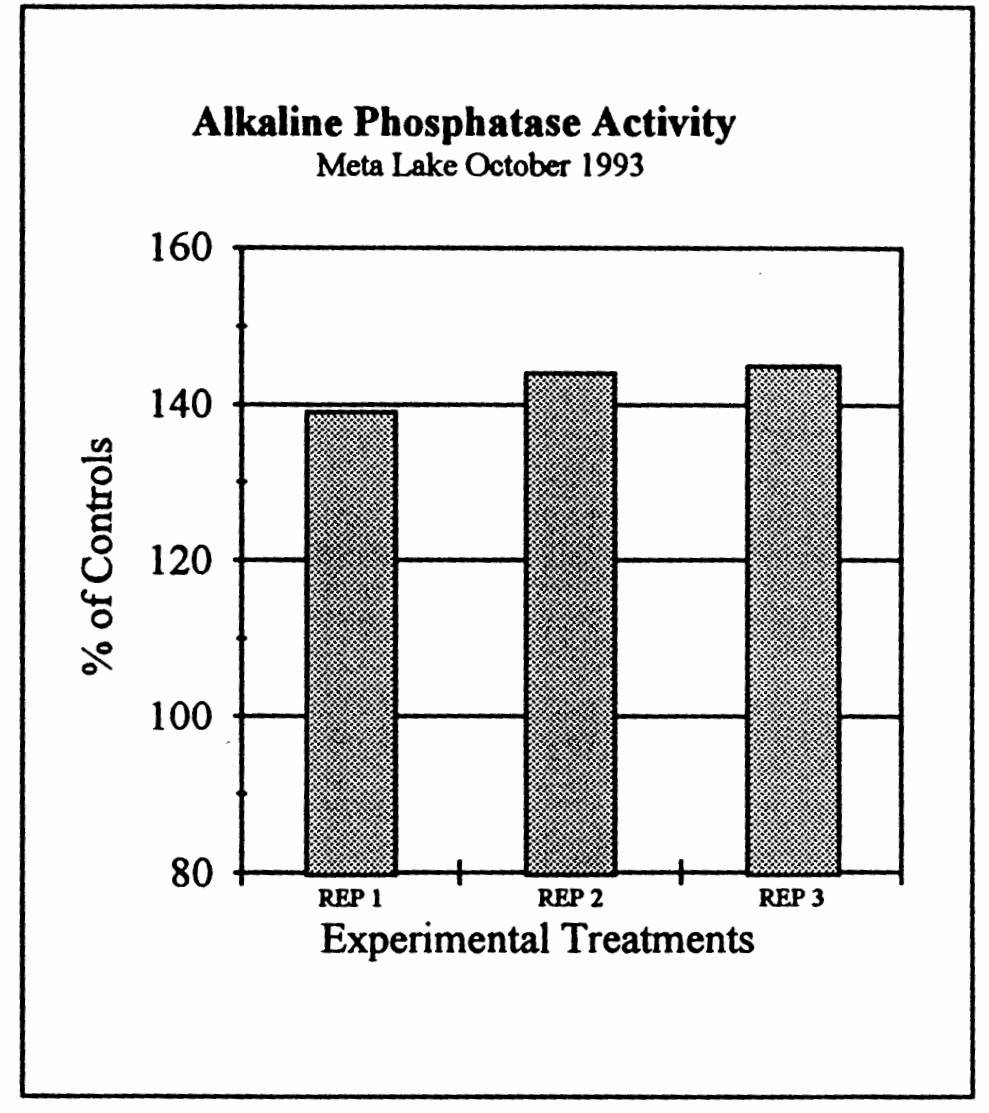

Figure 14 lake at this time.

Conclusion

Evidence from nutrient uptake and nutrient ratios suggests that the plankton in Meta Lake are limited by $\mathrm{N}$, although APA suggests colimitation by $\mathrm{P}$ also. SRP concentrations did not decrease through the growing season, suggesting adequate availability of $P$, although aggressive APA by the plankton may act to diminish the $P$ 
limitation. Compared to other lakes in this study only Hanaford and Ryan Lakes had higher APA activity, and other data from both these lakes suggest colimitation by $\mathbf{N}$ and $\mathbf{P}$. It appears that the plankton in Meta Lake are also colimited by $\mathrm{N}$ and $\mathrm{P}$. 
Table 7. Nutrient Concentrations and Ratios and Chlorophyll a Concentrations in Meta Lake (6-17-93). Values \pm 1 standard deviation.

\begin{tabular}{|c|c|c|c|c|c|c|c|c|c|c|}
\hline $\begin{array}{l}\text { Depth } \\
\text { (m) }\end{array}$ & $\begin{array}{l}\text { Chl. a } \\
(\mu g / 1)\end{array}$ & $\begin{array}{c}\text { SRP } \\
(\mu g / 1)\end{array}$ & $\underset{(\mu \mathrm{g} /)}{\operatorname{TP}}$ & $\begin{array}{c}\mathrm{NO}_{3}+\mathrm{NO}_{2} \\
(\mu \mathrm{g} / 1)\end{array}$ & $\begin{array}{l}\mathrm{NH}_{4} \\
(\mu g / 1)\end{array}$ & $\begin{array}{c}\text { TN } \\
(\mu g /)\end{array}$ & $\begin{array}{l}\mathrm{SiO}_{2} \\
(\mathrm{mg} / \mathrm{l})\end{array}$ & $S R N^{3}: S R P$ & $S R N^{3}: T P$ & TN:TP \\
\hline 1 & $\begin{array}{l}31.2^{1} \\
\pm 19.8\end{array}$ & $\begin{array}{r}5.2^{1} \\
\pm 2.9\end{array}$ & 18.4 & $\begin{array}{l}34.6 \\
\pm 1.3\end{array}$ & $\begin{array}{c}3.3 \\
\pm 0.1\end{array}$ & 32.7 & $\begin{array}{l}8.5 \\
\pm 0\end{array}$ & $10.3^{1}$ & 1.0 & 0.9 \\
\hline 4 & $\begin{array}{l}34.3^{1} \\
\pm 6.1\end{array}$ & $\begin{array}{l}2.0 \\
\pm 0\end{array}$ & 20.3 & $\begin{array}{l}35.4 \\
\pm 0.2\end{array}$ & $\begin{array}{c}7.0 \\
\pm 0.1\end{array}$ & 55.9 & $\begin{array}{c}9.0 \\
\pm 0.1\end{array}$ & 21.0 & 1.0 & 1.4 \\
\hline 7 & $\begin{array}{l}55.6^{1} \\
\pm 16.6\end{array}$ & $\begin{array}{l}1.7 \\
\pm 0\end{array}$ & 31.5 & $\begin{array}{l}18.6 \\
\pm 0.2\end{array}$ & $\begin{array}{l}8.4 \\
\pm 0.4\end{array}$ & 81.2 & $\begin{array}{l}11.7 \\
\pm 0.1\end{array}$ & 15.9 & 0.4 & 1.3 \\
\hline
\end{tabular}

${ }^{1}$ Questionable data (standard deviation $>\left(\right.$ value) ${ }^{1 / 2}$ ) ${ }^{2}$ N.D. No data ${ }^{3} \mathrm{SRN}=\mathrm{NO}_{3}+\mathrm{NO}_{2}+\mathrm{NH}_{4}$

Figure 15. Profiles of Temperature and Oxygen and Secchi Disk Depth in Meta Lake (6-17-93).
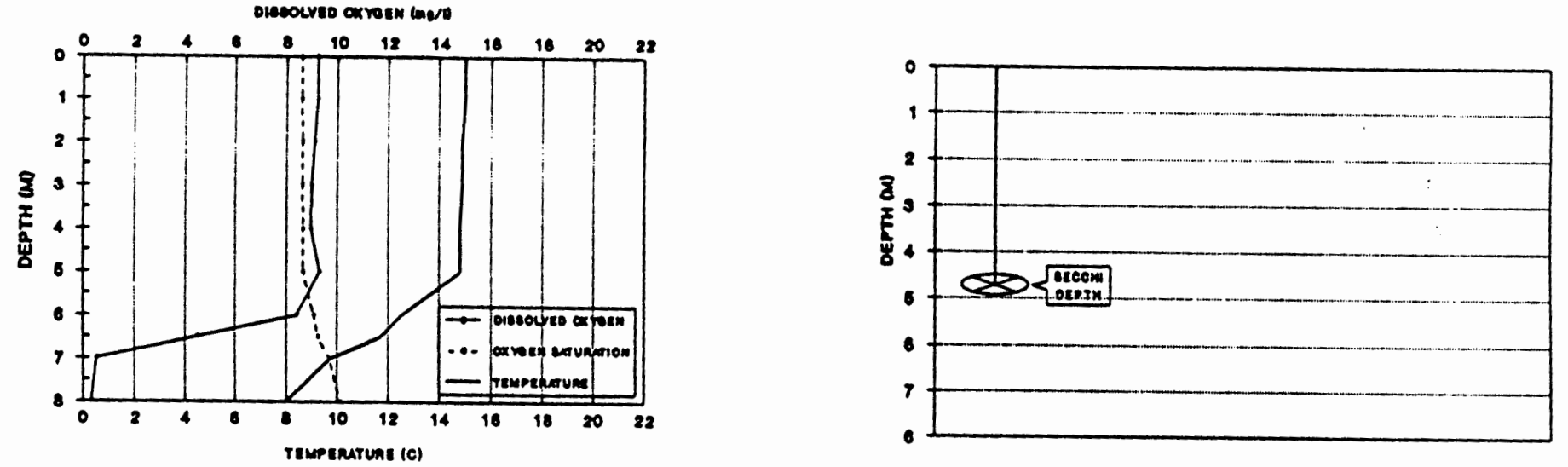
Table 8. Nutrient Concentrations and Ratios and Chlorophyll a Concentrations in Meta Lake (8-26-93). Values \pm 1 standard deviation.

\begin{tabular}{|c|c|c|c|c|c|c|c|c|c|c|}
\hline $\begin{array}{l}\text { Depth } \\
\text { (m) }\end{array}$ & $\begin{array}{l}\text { Chl. a } \\
(\mu g /)\end{array}$ & $\begin{array}{c}\text { SRP } \\
(\mu g /)\end{array}$ & $\underset{(\mu g /)}{\text { TP }}$ & $\begin{array}{c}\mathrm{NO}_{3}+\mathrm{NO}_{2} \\
(\mu \mathrm{g} /)\end{array}$ & $\begin{array}{l}\mathrm{NH}_{4} \\
(\mu \mathrm{g} /)\end{array}$ & $\begin{array}{c}\mathrm{TN} \\
(\mu \mathrm{g} / \mathrm{I})\end{array}$ & $\begin{array}{l}\mathrm{SiO}_{2} \\
(\mathrm{mg} / \mathrm{l})\end{array}$ & $S R N^{3}: S R P$ & $S R N^{3}: T P$ & TN:TP \\
\hline 1 & $\begin{array}{l}19.5^{1} \\
\pm 8.6\end{array}$ & $\begin{array}{c}2.3 \\
\pm 0.1\end{array}$ & $\begin{array}{l}19.5 \\
\pm 1.5\end{array}$ & $\begin{array}{c}2.4 \\
\pm 0.9\end{array}$ & $\begin{array}{l}0.7^{1} \\
\pm 0.7\end{array}$ & $\begin{array}{l}69.6 \\
\pm 0.5\end{array}$ & $\begin{array}{c}8.3 \\
\pm 0.1\end{array}$ & $1.4^{1}$ & $0.2^{1}$ & 3.6 \\
\hline 5 & $\begin{array}{r}10.7 \\
\pm 2.7\end{array}$ & $\begin{array}{c}2.7 \\
\pm 0.3\end{array}$ & $\begin{array}{l}28.8 \\
\pm 4.9\end{array}$ & $\begin{array}{c}2.4 \\
\pm 0.3\end{array}$ & $\begin{array}{l}0.2^{2} \\
\pm 0.2\end{array}$ & $\begin{array}{l}117.1^{2} \\
\pm 53.8\end{array}$ & $\begin{array}{c}8.2 \\
\pm 0.1\end{array}$ & $1.0^{1}$ & $0.1^{1}$ & $3.9^{1}$ \\
\hline 7.5 & $\begin{array}{r}20.7 \\
\pm 2.9\end{array}$ & $\begin{array}{c}3.2 \\
\pm 0.1\end{array}$ & $\begin{array}{l}42.6 \\
\pm 4.5\end{array}$ & $\begin{array}{c}2.8 \\
\pm 0.7\end{array}$ & $\begin{array}{l}2.1^{1} \\
\pm 1.5\end{array}$ & $\begin{array}{l}193.8^{1} \\
\pm 19.3\end{array}$ & $\begin{array}{c}9.8 \\
\pm 0.3\end{array}$ & $1.5^{1}$ & $0.1^{1}$ & $4.6^{1}$ \\
\hline
\end{tabular}

${ }^{1}$ Questionable data (standard deviation $>(\text { value })^{1 / 2}$ ) ${ }^{2} \mathrm{~N} . \mathrm{D}$. No data ${ }^{3} \mathrm{SRN}=\mathrm{NO}_{3}+\mathrm{NO}_{2}+\mathrm{NH}_{4}$

Figure 16. Profiles of Temperature, Oxygen, and Light Attenuation in Meta Lake (8-26-93).
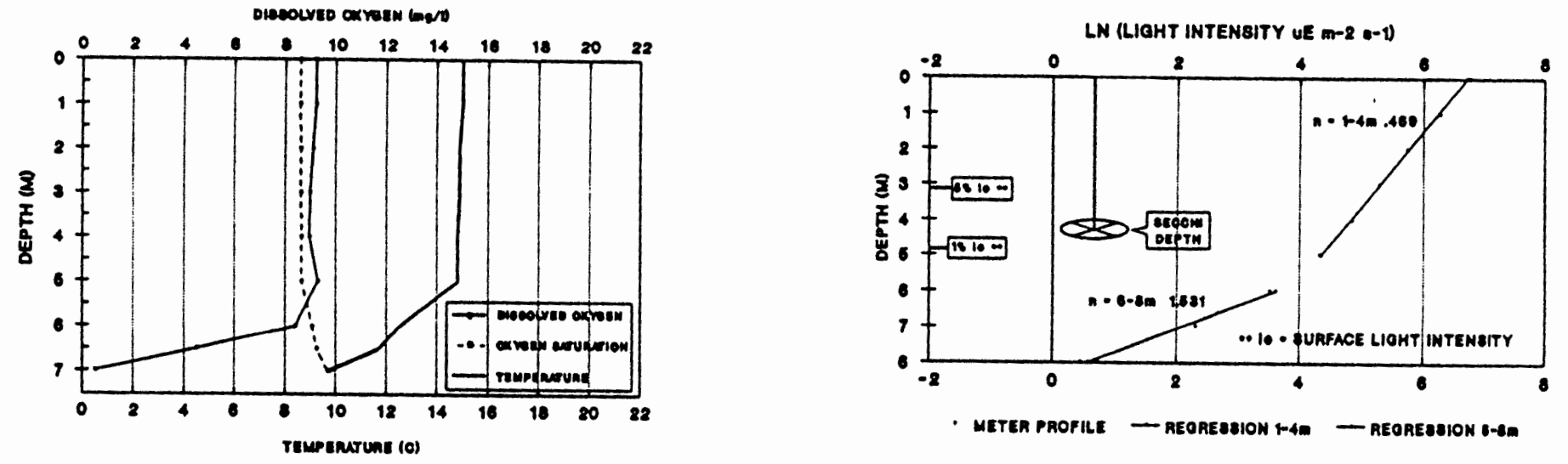
Table 9. Nutrient Concentrations and Ratios and Chlorophyll a Concentrations in Meta Lake (10-9-93). Values \pm 1 standard deviation.

\begin{tabular}{|c|c|c|c|c|c|c|c|c|c|c|}
\hline $\begin{array}{l}\text { Depth } \\
\text { (m) }\end{array}$ & $\begin{array}{l}\text { Chl. a } \\
(\mu g /)\end{array}$ & $\begin{array}{l}\text { SRP } \\
(\mu g / l)\end{array}$ & $\underset{(\mu \mathrm{g} /)}{\mathrm{TP}}$ & $\begin{array}{c}\mathrm{NO}_{3}+\mathrm{NO}_{2} \\
(\mu g /)\end{array}$ & $\begin{array}{l}\mathrm{NH}_{4} \\
(\mu \mathrm{g} / 1)\end{array}$ & $\begin{array}{c}\text { TN } \\
(\mu g / 1)\end{array}$ & $\begin{array}{l}\mathrm{SiO}_{2} \\
(\mathrm{mg} / \mathrm{l})\end{array}$ & $S R N^{3}: S R P$ & $S R N^{3}: T P$ & TN:TP \\
\hline 1 & $\begin{array}{l}20.8 \\
\pm 1.8\end{array}$ & $\begin{array}{c}2.3 \\
\pm 0.2\end{array}$ & $\begin{array}{l}15.2 \\
\pm 2.2\end{array}$ & $\begin{array}{c}0.8 \\
\pm 0.4\end{array}$ & $\begin{array}{l}15.8 \\
\pm 0.9\end{array}$ & $\begin{array}{l}92.6 \\
\pm 0.3\end{array}$ & $\begin{array}{l}9.8 \\
\pm 0.1\end{array}$ & 7.2 & 1.1 & 6.2 \\
\hline 4 & $\begin{array}{l}31.1 \\
\pm 4.9\end{array}$ & $\begin{array}{c}2.3 \\
\pm 0.2\end{array}$ & $\begin{array}{l}18.4 \\
\pm 1.1\end{array}$ & $\begin{array}{c}0.8 \\
\pm 0.5\end{array}$ & $\begin{array}{l}15.6 \\
\pm 1.9\end{array}$ & $\begin{array}{l}79.4 \\
\pm 0.8\end{array}$ & $\begin{array}{l}9.8 \\
\pm 0\end{array}$ & 7.3 & 0.8 & 4.3 \\
\hline 7 & $\begin{array}{l}80.2 \\
\pm 0.0\end{array}$ & $\begin{array}{c}2.7 \\
\pm 0.2\end{array}$ & $\begin{array}{l}26.4 \\
\pm 1.1\end{array}$ & $\begin{array}{c}2.3 \\
\pm 0.6\end{array}$ & $\begin{array}{l}16.3 \\
\pm 0.3\end{array}$ & $\begin{array}{l}110.2 \\
\pm 9.5\end{array}$ & $\begin{array}{l}10.4 \\
\pm 0\end{array}$ & 6.9 & 0.7 & 4.2 \\
\hline
\end{tabular}

N.D. No data ${ }^{3} \mathrm{SRN}=\mathrm{NO}_{3}+\mathrm{NO}_{2}+\mathrm{NH}_{4}$

Figure 17. Profiles of Temperature, Oxygen, and Light Attenuation in Meta Lake (10-9-93).
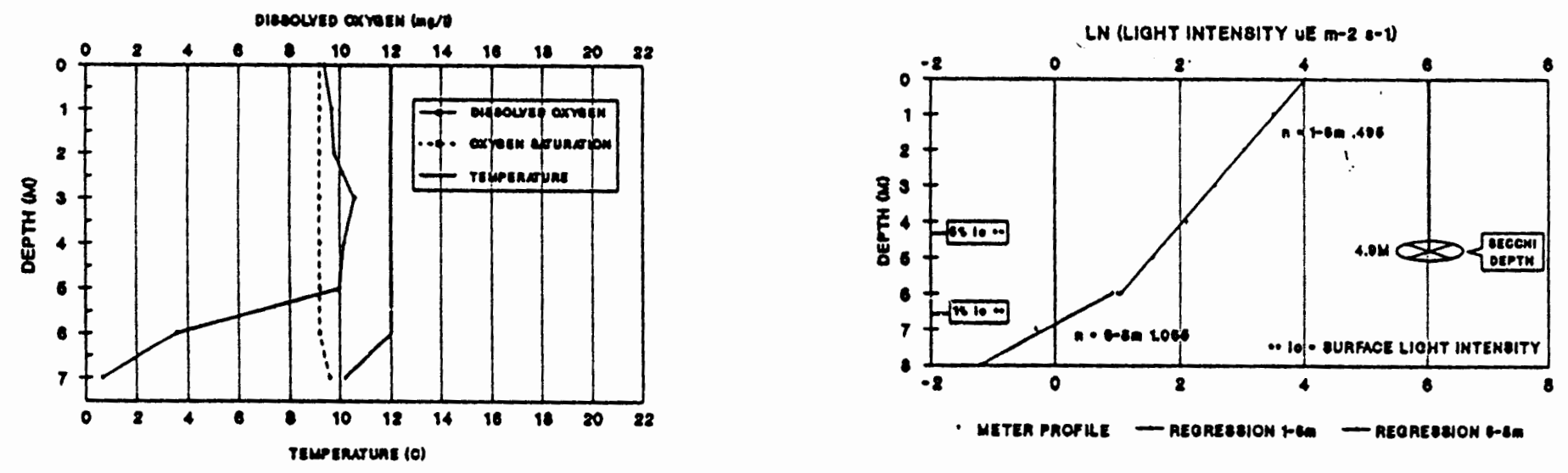


\section{Ryan Lake}

Ryan Lake lies in a cirque basin at an elevation of $1018 \mathrm{~m}, 19 \mathrm{~km}$ north of the mountain's crater. This previously oligotrophic subalpine lake is located at the edge of the blast zone and was severely impacted by the 1980 eruption. The Douglas Fir old growth forest which had surrounded the lake was destroyed and large amounts of ashfall and organic debris were deposited into the lake basin. In June 1980, the lake had the highest levels of dissolved organic carbon (DOC) and total bacterial and had the lowest concentrations of dissolved oxygen of all the pre-existing blast zone lakes (Wissmar et al. 1982a,b). Today, the lake contains large amounts of logs and woody debris, and the water is stained with dissolved organic materials. In 1993, the lake continued to have a substantial oxygen deficit in the hypolimnion and showed signs of nitrogen limitation, reflecting the relative inputs of $\mathrm{N}$ and $\mathrm{P}$ from the eruption.

\section{Temperature, Oxygen, and Light}

Profiles of temperature, oxygen, and light attenuation for Ryan Lake are found in Figures 22-24. Having a maximum depth of $7 \mathrm{~m}$, Ryan Lake fully mixes twice annually (i.e. is dimictic). Because of its relatively shallow depth and small volume, water temperatures in the lake were slightly elevated during this study. Surface temperatures ranged from $13-16^{\circ} \mathrm{C}$, while bottom temperatures were always greater than $10^{\circ} \mathrm{C}$. In August 1993, the lake was stratified with respect to temperature. A thermocline developed from 4-7 $\mathrm{m}$ which isolated the surface epilimnetic water from the bottom water. 
This prevented the oxygenation of the hypolimnion and oxygen levels declined as a consequence. One meter off the bottom, the oxygen concentration was $3.2 \mathrm{mg} / \mathrm{l}(35 \%$ saturation with respect to surface atmospheric pressure). By October 1993, the lake was nearly isothermal $\left(12^{\circ} \mathrm{C}\right)$ and the region of oxygen depletion moved up into the water column to $3 \mathrm{~m}$. At this time, oxygen concentrations below $3 \mathrm{~m}$ decreased steadily down to a minimum of $1.4 \mathrm{mg} / 1 \mathrm{~m}$ off the bottom ( $15 \%$ saturation).

Water transparency in Ryan Lake is low. During both years, the average extinction coefficient was $0.60 \mathrm{~m}^{-1}$ (range $0.36-2.0 \mathrm{~m}^{-1}$ ) and Secchi disk depths ranged from 4 to 5.5 meters. Profiles of light intensity reveal a dramatic increase in light attenuation in the hypolimnion. In August 1993 the extinction coefficient was $0.47 \mathrm{~m}^{-1}$ above and $0.74 \mathrm{~m}^{-1}$ below $4 \mathrm{~m}$. Some chemical or biological entity is attenuating the light in the lower half of the lake. A change in extinction coefficient in the deeper portion of the lake has been documented on previous samplings, but has not yet been identified. One percent light intensity was available at all depths during this study with the exception of the October 1993 sampling where $1 \%$ light intensity was found at $6 \mathrm{~m}$. These conditions suggest a mesotrophic classification for Ryan Lake.

\section{Nutrient Dynamics}

Concentrations of total and dissolved nutrients, chlorophyll-a and nutrient ratios for Ryan Lake are found in Tables 10-12. During three samplings in 1993, concentrations of SRP were consistently low, averaging $2.4 \mu \mathrm{g} /$ (range $1.9 \mu \mathrm{g} / 1-3.0 \mu \mathrm{g} / \mathrm{l}$ ).

Concentrations of $\mathrm{N}$ were also low in Ryan Lake, particularly in August. The average 
nitrate + nitrite concentration was $7.0 \mu \mathrm{g} / \mathrm{l}($ range $1.1 \mu \mathrm{g} / \mathrm{l}-25 \mu \mathrm{g} /$ ) and ammonium concentrations averaged $6.9 \mu \mathrm{g} / \mathrm{l}($ range $4.8-8.7 \mu \mathrm{g} / \mathrm{l})$.

Following the eruption, densities of microflagellates and protozoans in Ryan Lake were greater than $10^{5} / 1$ and are among the highest ever reported from lakes and reservoirs (Ward et al. 1983). These organisms were feeding upon the prolific numbers of bacteria, which reached $3 \times 10^{8} \mathrm{cells} / \mathrm{ml}$ (Dahm et al. 1983). The highest rates of nitrogen fixation ever reported in North America $\left(1.8-9.3 \mu \mathrm{g} \mathrm{N}_{2} \mathrm{~T}^{-1} \mathrm{~h}^{-1}\right)$ were from Ryan Lake the summer following the 1980 enuption. Benthic cyanobacteria and Anabaena sp. were thought to be responsible for the high rates of $\mathrm{N}$ fixation (Dahm et al. 1983).

During this study, the concentrations of DNN in the lake suggest that bacterial processes of nitrogen fixation and possibly nitrification and denitrification continue to influence the lake's ecology. Chlorophyll-a data indicate substantial phytoplankton growth in Ryan Lake. Photosynthetic oxygen production helps fuel aerobic decomposition of the organic matter in the lake.

DIN concentrations suggest that $\mathrm{N}_{2}$ fixation continues to be a source of $\mathrm{N}$ in the lake. Although bacterial counts were not performed, concentrations of TN and ammonium increased late into the summer when nutrient limiting conditions would be most pronounced. Concentrations of TN increased from $82.6 \mu \mathrm{g} /$ in August to $110 \mu \mathrm{g} / 1$ in October. Ammonium concentrations also increased from 5 to $7 \mu \mathrm{g} /$.

Elevated concentrations of nitrate + nitrite $(21.8 \mu \mathrm{g} / \mathrm{I})$ in June 1993 suggest bacterial nitrification in the spring, a time when dissolved oxygen concentrations were sufficient to support nitrification. Nitrifying bacteria oxidize reduced $\mathrm{N}$ compounds to 
nitrite and nitrate, harnessing the energy released in the process (Wetzel 1983).

From June to August 1993, concentrations of DIN decreased in the metalimnion from $32 \mu \mathrm{g} /$ to $10 \mu \mathrm{g} /$, with a concomitant increase in the chlorophyll-a concentration (from 25.2 to $38.5 \mu \mathrm{g} /$ ). These data suggesting nutrient assimilation and pigment production by the phytoplankton community.

Alternatively, bacterial denitrification may be responsible for the decrease in DIN concentrations in August 1993. Facultative anaerobic bacteria utilize oxidized species of $\mathrm{N}$ (such as nitrate) as terminal electron acceptors in the oxidation of organic substrates (Wetzel 1983). Following the 1980 eruption, denitrification by Mn-S-oxidizing bacteria represented a substantial sink for $N$ in Ryan Lake (Dahm et al. 1983). In August 1993, concentrations of oxygen in the lake were depleted and would have been conducive to such processes.

The depletion of DIN during the growing season coupled with evidence for $\mathbf{N}$ fixation suggests that $\mathrm{N}$ continues to limit the growth of the plankton in Ryan Lake. Bioassay data confirm the presence of $\mathrm{N}$ limitation in August 1993 (see below).

Concentrations of Si remained high throughout the year, and was always above 8.2 mg/. In 1993, the dominant phytoplankton species in Ryan Lake were Cryptomonas erosa, the dinoflagellate Ceratium hirundinella, and the Chrysophyte Kephyrion sp. (Baker 1995). Kephyrion and various diatoms in the lake contain silica as part of their outer cell wall and thus use Si as a major nutrient (Smith 1933). From June to August 1993, concentrations of Si decreased in the metalimnion from 9.9 to $8.3 \mathrm{mg} /$, possibly from phytoplankton uptake. In general, $\mathrm{Si}$ is plentiful in Ryan Lake and probably does not 
confine plankton growth.

\section{Nutrient Ratios}

DIN:SRP ratios for Ryan Lake during 1993 differ with respect to both sampling date and depth. Elevated concentrations of nitrate + nitrite in June 1993 produced DIN:SRP ratios near 12. In August 1993, however, the DIN:SRP ratio was below 4 in the metalimnion, where the chlorophyll-a concentration was the highest. These data suggest nitrogen limitation, although the SRP concentration $(2.7 \mu \mathrm{g} / \mathrm{l})$ provides evidence for colimitation by $\mathrm{N}$ and $\mathrm{P}$. By October, the degree of $\mathrm{N}$ limitation increased as the DIN:SRP ratio in the metalimnion decreased to 3.5 .

From June to August, 1993, the TN:TP ratio in the metalimnion increased from 3 to 10. This increase may be the result of $\mathrm{N}_{2}$ fixation by the plankton in the lake. During this study the average TN:TP ratio was 8.4 in Ryan Lake, suggesting $\mathrm{N}$ limitation.

\section{Bioassays}

\section{Alkaline Phosphatase}

Data on alkaline phosphatase enzyme activity in Ryan Lake during October 1993 suggests that the plankton community in Ryan Lake is P deficient. Plankton collected from $4 \mathrm{~m}$ depth produced a $30.3 \%$ average (SD 1.7) increase in APA, compared to blank controls (Figure 18). These data indicate that $\mathbf{P}$ is in short supply in Ryan Lake. 
Long Term Enrichment

Various measures

of plankton growth

(chlorophyll-a

production and carbon

fixation) following

nutrient addition

suggests that the

phytoplankton and

heterotrophic organisms

(e.g. bacteria) in Ryan

Lake respond differently

to enrichment.

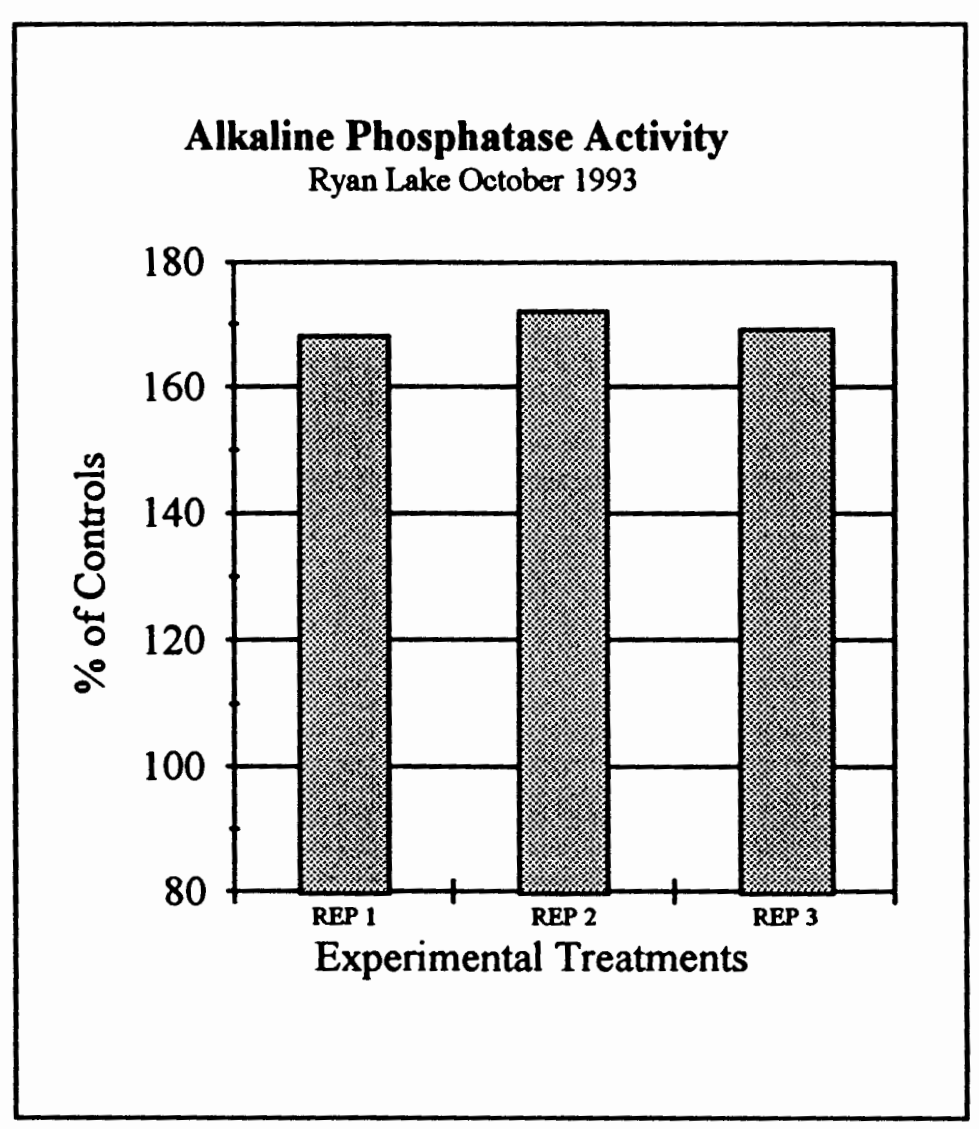

Figure 18

Fertilization experiments using 20 liter polyethylene bags indicate that both $\mathrm{N}$ and $\mathrm{P}$ limit the productivity (growth) of the plankton community in the lake. Chlorophyll-a concentrations inside the bags either increased or decreased, depending on which nutrient was added. Phosphorus stimulated chlorophyll-a productions inside the bags by $175 \%$ compared to controls (Figure 19). Two way analysis of variance (ANOVA) indicates a significant response $(P=0.01)$ with the addition of $P$. This indicates that the photosynthetic plankton are limited by $\mathbf{P}$. Nitrogen fertilizations, either by itself or in combination with P significantly suppressed chlorophyll-a concentrations inside the bags.

The bags given $\mathrm{N}$ (as $\mathrm{N}$ or N\&P) contained only $30 \%$ as much chlorophyll-a as control 
bags. ANOVA revealed significance for $+N(P=$ $0.016)$ and $+N \& P(P=$ 0.012). One explanation for these data is that chemolithotrophic bacteria (ammonium oxidizers) were using the additional $\mathrm{N}$ for growth and consequently were competing with the autotrophic phytoplankton for available P. Bacterial uptake of $P$ has been shown

Chlorophyll a Response

Ryan Lake August 1993

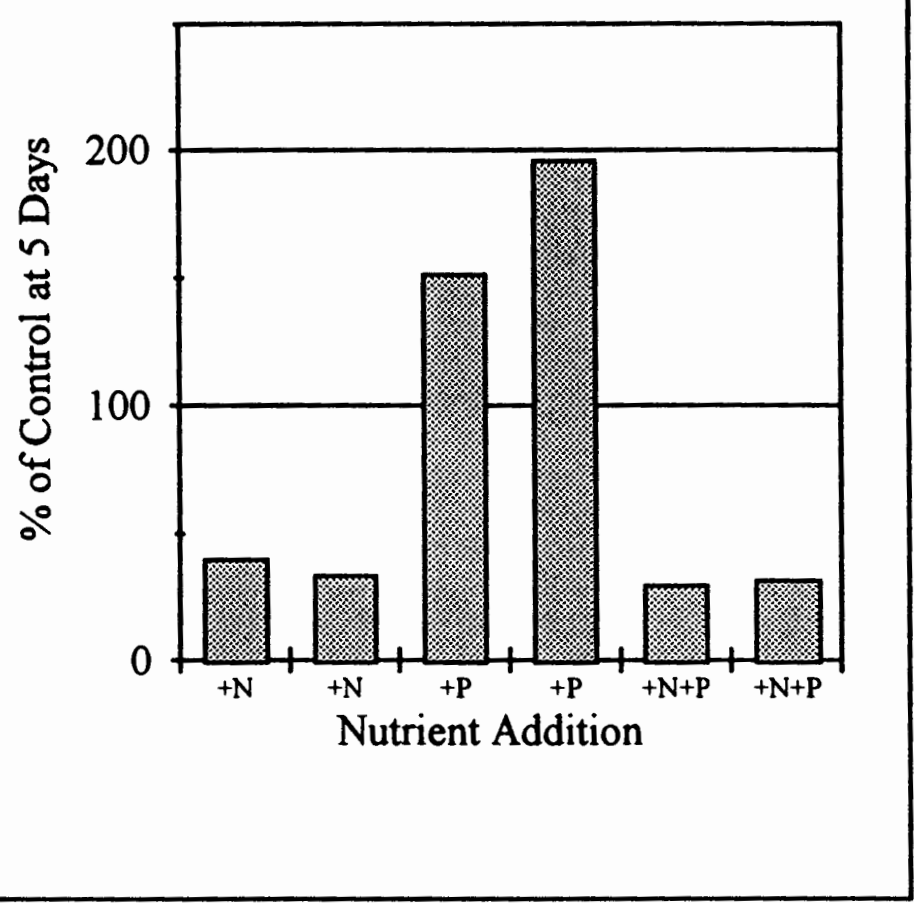

Figure 19

to be much more efficient than phytoplankton. Currie and Kalff (1984) demonstrated bacterial affinities for $P$ that were an order of magnitude greater than those for some algal species. Although specific bacterial activities were not measured in this study, indirect evidence for ammonium oxidation was found. The concentration of nitrate+nitrite increased inside bags given $\mathrm{N}$ (from 1.3 to $3.2 \mu \mathrm{g} / \mathrm{l}$ ). Without further information, it is not possible to confirm the cause of these results.

Carbon fixation measured from replicate bags increased in all treatments $(+N=171 \%,+P=130 \%,+N \& P=200 \%)$ compared to controls (Figure 20). A two way nested analysis of variance (ANOVA) indicated a significant response for all treatments 
$(+\mathrm{N} P \quad 0.001,+\mathrm{P}$

P $0.01,+N \& P$ P

0.001 ). The addition of

$\mathrm{N}$ caused a greater

response than $\mathrm{P}$ and

suggests primary

limitation by $N$. The

synergistic interaction

between $\mathrm{N}$ and $\mathrm{P}$

indicates that the

limitation by $\mathrm{N}$ is

relieved with the

\section{Carbon Uptake in the Light}

Ryan Lake August 1993

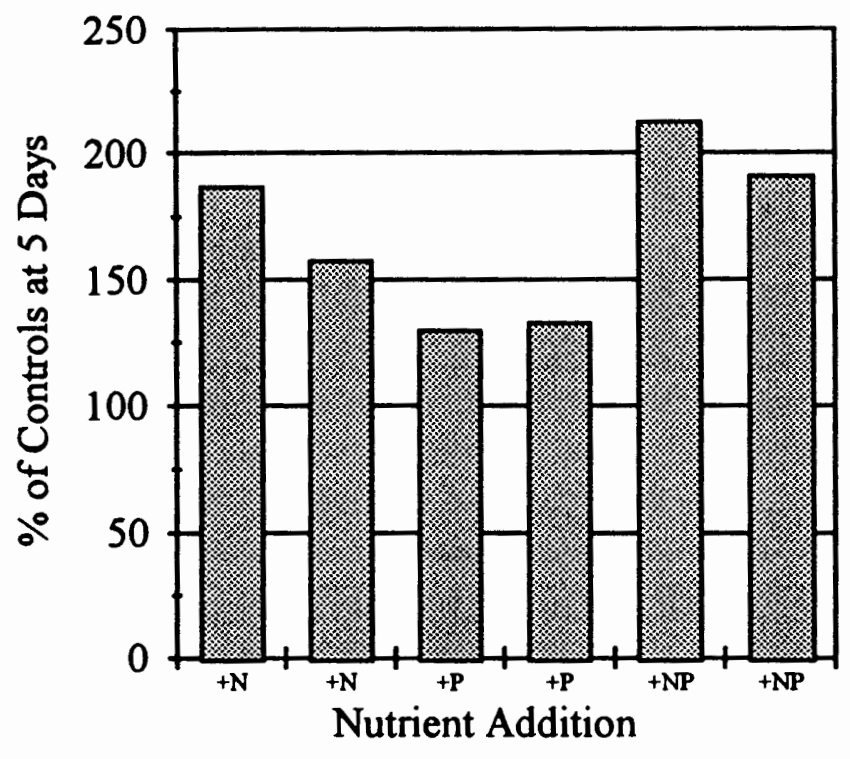

addition of $70 \mu \mathrm{g} / \mathrm{N}$.

Figure 20

At these concentrations of added N, P limitation is induced and further increases in carbon fixation are produced when N\&P are added together. The concentration of $P$ inside the bags given $\mathrm{N} \& \mathrm{P}$ were less than those given $\mathrm{P}$ alone, providing further evidence for $\mathrm{N}$ limitation. If $\mathrm{N}$ was limiting, the addition of $\mathrm{N}$ would increase growth, which would require additional $\mathrm{P}$ uptake. Curiously, additions of $\mathrm{N}$ did not cause SRP concentrations to decline. It is possible that regeneration of $\mathrm{P}$ by the plankton or increased APA could have provided sufficient $P$ for continued growth. Compared to controls, the addition of $\mathrm{N}$ stimulated APA by an average of $60 \%$ (Figure 21), indicating that APA 
was not maximal in the

controls. Although the data

are variable, the addition of $P$

produced a $20 \%$ average

decrease in APA compared to

controls, indicating that $\mathbf{P}$

was no longer in short

supply.

\section{Conclusion}

It appears that the bacteria in Ryan Lake continue to process organic

\section{Alkaline Phosphatase Activity}

Ryan Lake August 1993

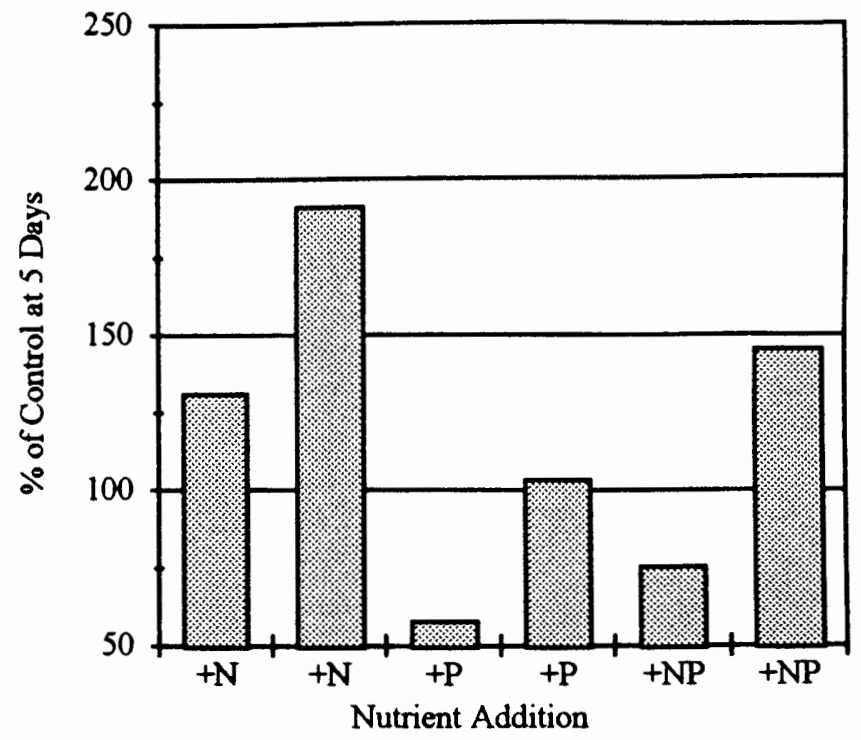

Figure 21

material, a legacy from the May, 1980 eruption. The oxygen profiles and nutrient data suggest that bacterial metabolism is still active, particularly as it pertains to nitrogen cycling.

Several approaches to nutrient limitation in Ryan Lake portray a complicated, dynamic picture. Carbon fixation increased with all treatments, while chlorophyll-a production was increased only with $\mathrm{P}$ additions. $\mathrm{N}$ decreased pigment production, possibly due to bacterial uptake or assimilation of $\mathrm{N}$ into alternative products. Depending on the nutrient supply and physiological state of the algal cells, carbon fixation may be associated with pigment production (chlorophyll-a), or the formation of other assimilation 
products, such as proteins, carbohydrates, and lipids (Groeger and Kimmel 1988). Studies following the 1980 eruption indicated that the bacteria community in the lake dominated processes of nutrient uptake and cycling. Bacteria compete with algae for nutrients and have certainly filled an important niche in the blast zone lakes. The evidence suggests that the phytoplankton in Ryan Lake are limited by $\mathrm{P}$ while non-photosynthesizing organisms are limited by $\mathrm{N}$. Together with evidence from alkaline phosphatase activity and nutrient concentrations and ratios, these bioassays implicate both $\mathrm{N}$ and $\mathrm{P}$ as limiting plankton growth in the lake. Again it is emphasized that bacterial metabolic activities need to be examined when evaluating processes of nutrient uptake and growth by the plankton, particularly in lakes which contain high amounts of organic materials. 
Table 10. Nutrient Concentrations and Ratios and Chlorophyll a Concentrations in Ryan Lake (6-17-93). Values \pm 1 standard deviation.

\begin{tabular}{|c|c|c|c|c|c|c|c|c|c|c|}
\hline $\begin{array}{l}\text { Depth } \\
\text { (m) }\end{array}$ & $\begin{array}{l}\text { Chl. a } \\
(\mu g / 1)\end{array}$ & $\begin{array}{c}\text { SRP } \\
(\mu g /)\end{array}$ & $\begin{array}{c}\text { TP } \\
(\mu g / 1)\end{array}$ & $\begin{array}{c}\mathrm{NO}_{3}+\mathrm{NO}_{2} \\
(\mu \mathrm{g} /)\end{array}$ & $\begin{array}{l}\mathrm{NH}_{4} \\
(\mu g / 1)\end{array}$ & $\begin{array}{c}\text { TN } \\
(\mu g / 1)\end{array}$ & $\begin{array}{l}\mathrm{SiO}_{2} \\
(m g / 1)\end{array}$ & SRN':SRP & $\mathrm{SRN}^{3}: \mathrm{TP}$ & TN:TP \\
\hline 1 & $\begin{array}{l}13.9 \\
\pm 2.6\end{array}$ & $\begin{array}{c}2.2 \\
\pm 0.2\end{array}$ & 9.7 & $\begin{array}{l}19.7 \\
\pm 0.4\end{array}$ & $\begin{array}{l}6.5 \\
\pm 0.9\end{array}$ & 42.7 & $\begin{array}{l}9.8 \\
\pm 0\end{array}$ & 12.1 & 2.6 & 4.4 \\
\hline 4 & $\begin{array}{l}25.2 \\
\pm 0.2\end{array}$ & $\begin{array}{c}2.5 \\
\pm 0.2\end{array}$ & 10.4 & $\begin{array}{l}25.5 \\
\pm 1.7\end{array}$ & $\begin{array}{l}6.6 \\
\pm 0\end{array}$ & 30.1 & $\begin{array}{l}9.9 \\
\pm 0\end{array}$ & 12.8 & 2.9 & 2.9 \\
\hline 6 & $\begin{array}{l}44.3^{1} \\
\pm 14.6\end{array}$ & $\begin{array}{c}1.9 \\
\pm 0.2\end{array}$ & 7.2 & $\begin{array}{c}20.2 \\
\pm 0\end{array}$ & $\begin{array}{c}5.2 \\
\pm 0.4\end{array}$ & 36.9 & $\begin{array}{c}9.9 \\
\pm 0.1\end{array}$ & 13.8 & 3.5 & 5.1 \\
\hline
\end{tabular}

${ }^{1}$ Questionable data (standard deviation $>(\text { value })^{1 / 2}$ ) ${ }^{2} \mathrm{~N} . \mathrm{D}$. No data ${ }^{3} \mathrm{SRN}=\mathrm{NO}_{3}+\mathrm{NO}_{2}+\mathrm{NH}_{4}$

Figure 22. Profiles of Temperature, Oxygen, and Light Attenuation in Ryan Lake (6-17-93).
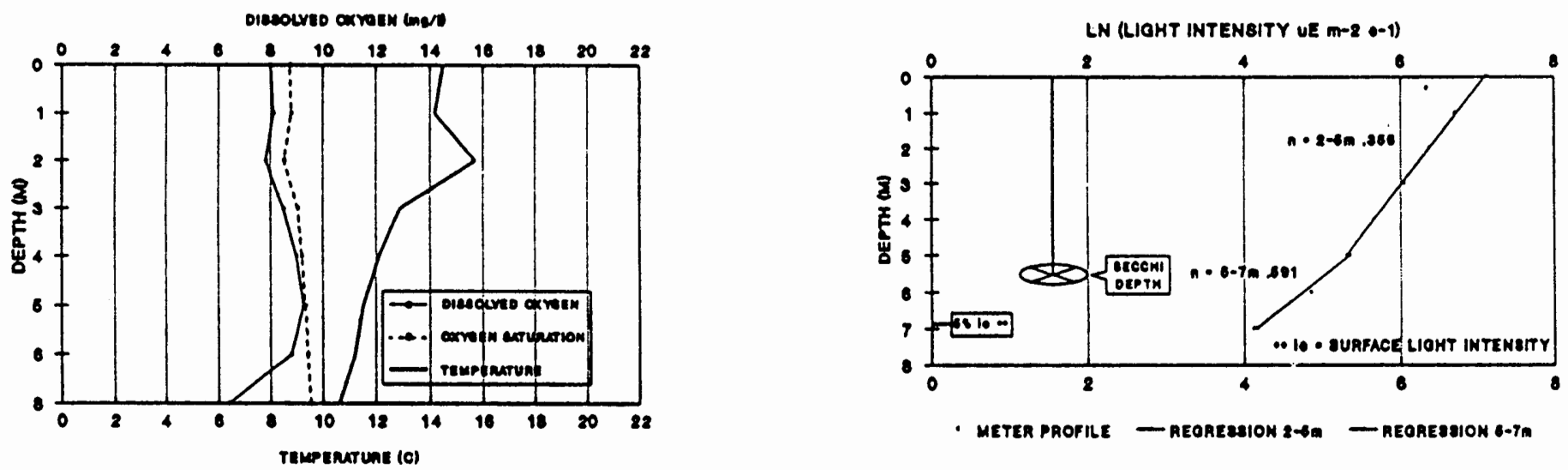
Table 11. Nutrient Concentrations and Ratios and Chlorophyll a Concentrations in Ryan Lake (8-24-93). Values \pm 1 standard deviation.

\begin{tabular}{|c|c|c|c|c|c|c|c|c|c|c|}
\hline $\begin{array}{l}\text { Depth } \\
\text { (m) }\end{array}$ & $\begin{array}{l}\text { Chl. a } \\
(\mu g / l)\end{array}$ & $\begin{array}{c}\text { SRP } \\
(\mu \mathrm{g} / \mathrm{l})\end{array}$ & $\underset{(\mu g /)}{\operatorname{TP}}$ & $\begin{array}{c}\mathrm{NO}_{3}+\mathrm{NO}_{2} \\
(\mu \mathrm{g} / \mathrm{l})\end{array}$ & $\begin{array}{l}\mathrm{NH}_{4} \\
(\mu \mathrm{g} / \mathrm{l})\end{array}$ & $\begin{array}{c}\text { TN } \\
(\mu g /)\end{array}$ & $\begin{array}{l}\mathrm{SiO}_{2} \\
(\mathrm{mg} / \mathrm{l})\end{array}$ & $\mathrm{SRN}^{3}: \mathrm{SRP}$ & $S R N^{3}: T P$ & TN:TP \\
\hline 1 & $\begin{array}{r}17.2 \\
\pm 1.4\end{array}$ & $\begin{array}{c}2.6 \\
\pm 0.1\end{array}$ & $\begin{array}{c}8.1 \\
\pm 1.3\end{array}$ & $\begin{array}{c}4.6 \\
\pm 0.9\end{array}$ & $\begin{array}{c}4.8 \\
\pm 0.9\end{array}$ & $\begin{array}{l}82.6 \\
\pm 6.1\end{array}$ & $\begin{array}{l}8.2 \\
\pm 0\end{array}$ & 3.7 & 1.2 & 10.3 \\
\hline 4 & $\begin{array}{r}38.5 \\
+6.2\end{array}$ & $\begin{array}{c}2.7 \\
\pm 0.3\end{array}$ & $\begin{array}{r}11.9 \\
\pm 2.2\end{array}$ & $\begin{array}{c}4.8 \\
\pm 1.8\end{array}$ & $\begin{array}{c}5.5 \\
\pm 1.1\end{array}$ & $\begin{array}{l}119.0 \\
\pm 9.8\end{array}$ & $\begin{array}{l}8.3 \\
\pm 0\end{array}$ & 3.9 & 0.8 & 10.5 \\
\hline 6 & $\begin{array}{r}54.7^{1} \\
\pm 39.8\end{array}$ & $\begin{array}{c}3.0 \\
\pm 0.3\end{array}$ & $\begin{array}{l}13.9 \\
\pm 0.5\end{array}$ & $\begin{array}{l}1.2 \\
\pm 0\end{array}$ & $\begin{array}{c}8.6 \\
\pm 2.4\end{array}$ & $\begin{array}{l}118.7 \\
\pm 4.2\end{array}$ & $\begin{array}{c}9.2 \\
\pm 0.1\end{array}$ & 3.4 & 0.7 & 8.5 \\
\hline
\end{tabular}

${ }_{1}^{1}$ Questionable data (standard deviation $>(\text { value })^{1 / 2}$ ) ${ }^{2} \mathrm{~N}$.D. No data ${ }^{3} \mathrm{SRN}=\mathrm{NO}_{3}+\mathrm{NO}_{2}+\mathrm{NH}_{4}$

Figure 23. Profiles of Temperature, Oxygen, and Light Attenuation in Ryan Lake (8-24-93).
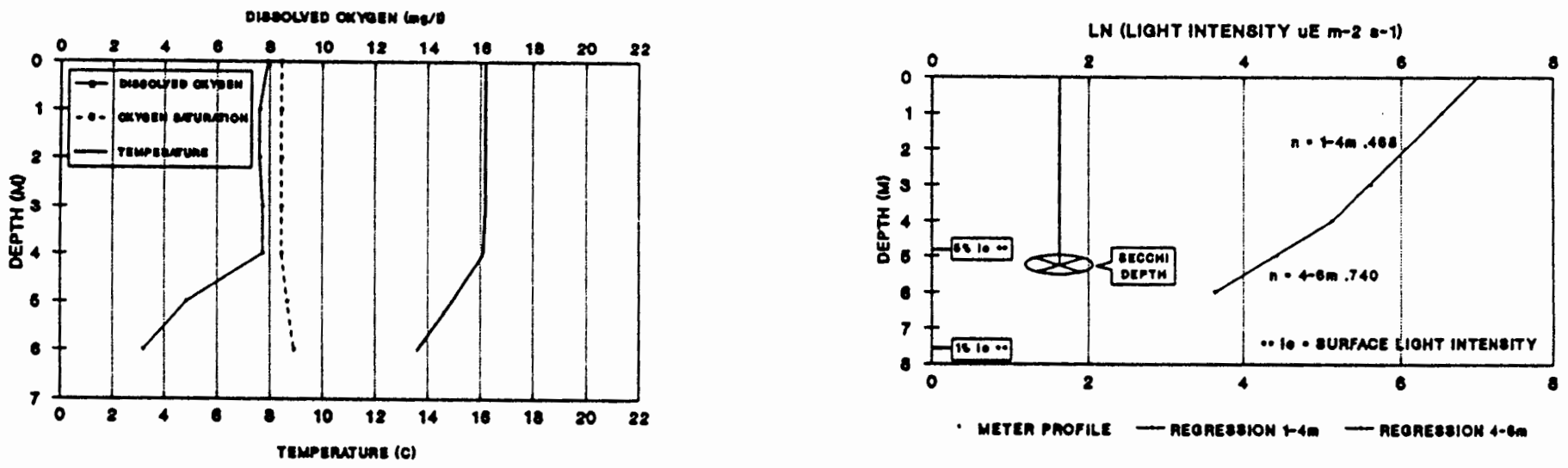
Table 12. Nutrient Concentrations and Ratios and Chlorophyll a Concentrations in Ryan Lake (10-9-93). Values \pm 1 standard deviation.

\begin{tabular}{|c|c|c|c|c|c|c|c|c|c|c|}
\hline $\begin{array}{l}\text { Depth } \\
\text { (m) }\end{array}$ & $\begin{array}{l}\text { Chl. a } \\
(\mu g / 1)\end{array}$ & $\begin{array}{l}\text { SRP } \\
(\mu g /)\end{array}$ & $\begin{array}{c}\mathrm{TP} \\
(\mu g /)\end{array}$ & $\begin{array}{c}\mathrm{NO}_{3}+\mathrm{NO}_{2} \\
(\mu \mathrm{g} /)\end{array}$ & $\begin{array}{l}\mathrm{NH}_{4} \\
(\mu \mathrm{g} /)\end{array}$ & $\begin{array}{c}\text { TN } \\
(\mu g /)\end{array}$ & $\begin{array}{l}\mathrm{SiO}_{2} \\
(\mathrm{mg} / \mathrm{l})\end{array}$ & SRN $N^{3}: S R P$ & SRN & TN:TP \\
\hline 1 & $\begin{array}{l}21.4 \\
\pm 3.0\end{array}$ & $\begin{array}{c}2.2 \\
\pm 0.2\end{array}$ & $\begin{array}{l}13.5 \\
\pm 0.5\end{array}$ & $\begin{array}{c}1.1 \\
\pm 0.2\end{array}$ & $\begin{array}{c}7.2 \\
\pm 0.4\end{array}$ & $\begin{array}{l}110.0 \\
\pm 10.3\end{array}$ & $\begin{array}{l}9.2 \\
\pm 0\end{array}$ & 3.7 & 0.6 & 8.1 \\
\hline 4 & $\begin{array}{l}17.7 \\
\pm 1.7\end{array}$ & $\begin{array}{c}2.5 \\
\pm 0.3\end{array}$ & $\begin{array}{l}14.6 \\
\pm 2.0\end{array}$ & $\begin{array}{c}1.1 \\
\pm 0.3\end{array}$ & $\begin{array}{c}7.2 \\
\pm 0.7\end{array}$ & $\begin{array}{l}139.3^{1} \\
\pm 12.7\end{array}$ & $\begin{array}{l}9.2 \\
\pm 0\end{array}$ & 3.5 & 0.5 & $9.8^{1}$ \\
\hline 6 & $\begin{array}{l}23.5 \\
\pm 0.7\end{array}$ & $\begin{array}{c}2.4 \\
\pm 0.3\end{array}$ & $\begin{array}{l}12.8 \\
\pm 0.5\end{array}$ & $\begin{array}{l}1.8 \\
\pm 0.5\end{array}$ & $\begin{array}{c}8.7 \\
\pm 1.2\end{array}$ & $\begin{array}{l}120.3 \\
\pm 5.8\end{array}$ & $\begin{array}{l}9.2 \\
\pm 0\end{array}$ & 4.5 & 0.7 & 9.4 \\
\hline
\end{tabular}

${ }^{1}$ Questionable data (standard deviation $>(\text { value })^{1 / 2}$ ) ${ }^{2}$ N.D. No data ${ }^{3} \mathrm{SRN}=\mathrm{NO}_{3}+\mathrm{NO}_{2}+\mathrm{NH}_{4}$

Figure 24. Profiles of Temperature, Oxygen, and Light Attenuation in Ryan Lake (10-9-93).
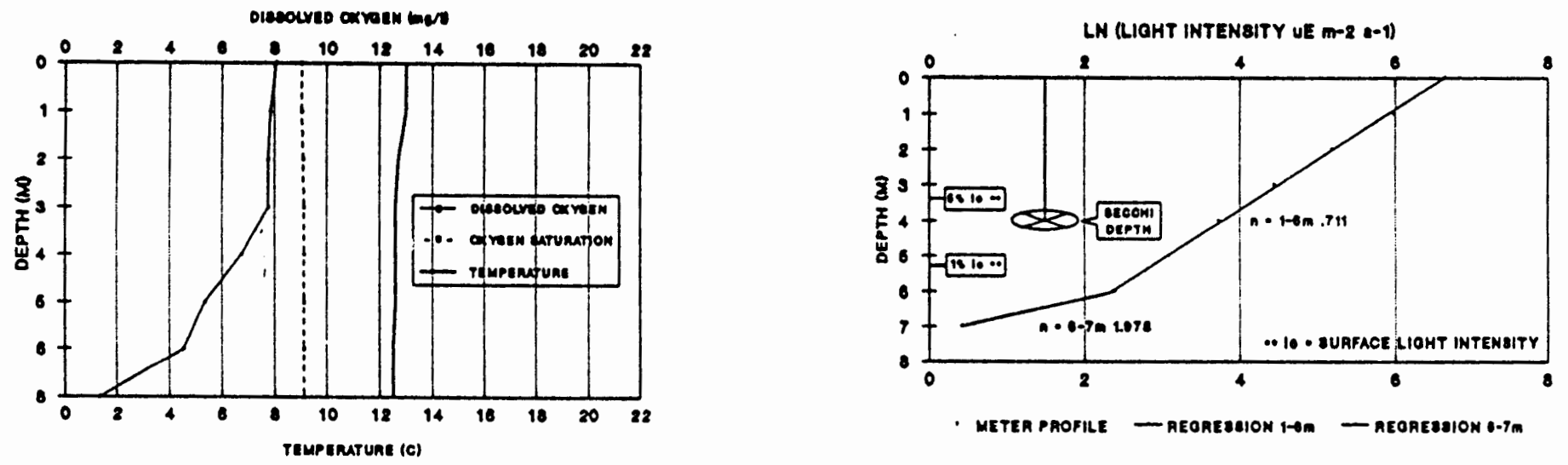


\section{Boot Lake}

Boot Lake lies in a cirque basin at an elevation of $1415 \mathrm{~m}, 15 \mathrm{~km}$ northeast of the mountain's crater. This alpine lake has a cirque amphitheater to the south and a perennial stream enters the lake also from the south. Because of its protected location beyond Mount Margaret, the lake received less direct inputs from the blast than other lakes in the blast zone, although large trees in the watershed were denuded of their vegetation and blown down, sending large amounts of dissolved organic carbon (DOC) into the lake. The lake contained the second highest levels of DOC $(4.98 \mathrm{mg} / \mathrm{l})$ of the preexisting blast zone lakes, which reflects the substantial effect the eruption had on the lake's water chemistry (Wissmar et al. 1982 b).

\section{Temperature, Oxygen, and Light}

Profiles of temperature, oxygen, and light attenuation for Boot Lake are presented in Figure 25. Having a maximum depth of $14.5 \mathrm{~m}$, Boot Lake turns over twice each year (i.e. is dimictic) and develops a thermocline in the summer. In August 1993, surface temperatures reached $12 \mathrm{C}$ and the epilimnion extended to a depth of $4 \mathrm{~m}$. At this time, a continuous thermocline penetrated down to $12 \mathrm{~m}$, where temperatures were $5 \mathrm{C}$ throughout the hypolimnion.

Oxygen was saturated in the epilimnion and increased with depth. In August 1991 and August 1993, concentrations of oxygen were elevated at 8 and $6 \mathrm{~m}$, respectively. Respective oxygen concentrations reached $170 \%$ and $125 \%$ saturation, indicating 
phytoplankton photosynthesis at these depths. In 1993, oxygen concentrations remained nearly saturated to the bottom of the lake. This contrasts with the anoxic conditions measured in the hypolimnion in 1991 (unpublished data).

Water transparency in Boot Lake is high, although decreased transparency in the hypolimnion continues to be characteristic. Profiles of light intensity and Secchi disk depth reveal a dramatic increase in light attenuation below $8 \mathrm{~m}$. The extinction coefficient was $0.24 \mathrm{~m}^{-1}$ above and $0.54 \mathrm{~m}^{-1}$ below $8 \mathrm{~m}$. Some chemical or biological entity is attenuating the light in the lower half of the lake. A change in extinction coefficient in the deeper portion of the lake has been documented on previous samplings, but has not yet been identified. Further, 1\% surface light intensity was available throughout the water column during the August 1993 sampling. These data indicate oligotrophic conditions in Boot Lake, although the oxygen depletion in the hypolimnion suggests a slightly more productive classification.

\section{Nutrient Dynamics}

Concentrations of total and dissolved nutrients, chlorophyll-a and nutrient ratios for Boot Lake are found in Table 13. The SRP concentrations in Boot Lake were low, averaging $1.4 \mu \mathrm{g} / \mathrm{l}$ (range $0.7-2.7 \mu \mathrm{g} / \mathrm{l})$. The average nitrate + nitrite concentration was $65.3 \mu \mathrm{g} / \mathrm{l}$ (range $43.8-91.0 \mu \mathrm{g} / \mathrm{l}$ ) and ammonium averaged $2.8 \mu \mathrm{g} / \mathrm{l}$ (range $1.0-5.8 \mu \mathrm{g} / \mathrm{l}$ ).

The availability of SRP throughout the water column was limited in Boot Lake, especially in the epilimnion, where concentrations were $0.9 \mu \mathrm{g} / \mathrm{l}$. This depletion of SRP coincides with the maximum total $\mathrm{P}$ concentration of $21 \mu \mathrm{g} / \mathrm{l}$ in the lake. Ammonium was 
also depleted in the epilimnion $(1.0 \mu \mathrm{g} / \mathrm{l})$, although substantial oxidized nitrogen was available. The uptake and assimilation of DIN and SRP by photosynthesizing phytoplankton may deplete these nutrients to limiting concentrations.

In August 1993, concentrations of DIN were highest in the bottom waters. The concentration of nitrate+nitrite in the hypolimnion was $91.0 \mu \mathrm{g} / \mathrm{l}$ and ammonium was 5.8 $\mu \mathrm{g} /$. Light availability at this depth was less than $1 \%$ surface light intensity which may be below the depth at which the energy gained from photosynthesis meets metabolic requirements (the compensation point) for the phytoplankton. The inability of the phytoplankton to take up nutrients at this depth would result in such nutrient accumulations, particularly during periods of strong thermal stratification (see Figure 25).

Concentrations of Si remained high throughout the year, and were always above $6.6 \mathrm{mg} / \mathrm{l}$. In 1993 the dominant phytoplankton species in Boot Lake were the diatom Fragilaria crotonensis and the dinoflagellate Glenodinium (Baker 1995). In August 1993, concentrations of Si were lowest in the epilimnion $(6.6 \mathrm{mg} / \mathrm{l})$ and increased with increasing depth (up to $7.6 \mathrm{mg} / \mathrm{lin}$ the hypolimnion). This may reflect the dissolution of Si from the bottom sediments or assimilation and sedimentation of Si from diatoms to the bottom. Because Si is so plentiful in Boot Lake, it is doubtful that this nutrient would limit the growth of the phytoplankton.

Elevated chlorophyll-a concentrations at $7 \mathrm{~m}$ indicate that a population of phytoplankton is growing in the metalimnion. Decreased concentrations of nitrate + nitrite in the metalimnion $(61.2 \mu \mathrm{g} / \mathrm{l}$ at $1 \mathrm{~m}$ to $43.8 \mu \mathrm{g} / \mathrm{l}$ at $7 \mathrm{~m})$ suggests uptake of this nutrient and assimilation into chlorophyll-a. 


\section{Nutrient Ratios}

DIN:SRP ratios for Boot Lake clearly indicate that $P$ is the limiting nutrient for the plankton. In August 1993, the DIN:SRP was high at all depths (always above 70), resulting from abundant DIN and scarce SRP. TN:TP ratios were low in Boot Lake ( $s$ 1.5) in the metalimnion (suggesting $\mathrm{N}$ limitation), although TN data is questionable (see Table 13). Since the concentrations of TN were less than concentrations of DIN at the same depths, these ratios should not be considered in the evaluation of nutrient limitation.

\section{Conclusion}

1993 data from Boot Lake indicate that the lake has recovered from the 1980 eruption in terms of dissolved oxygen, water clarity, and plankton abundance, although the cause of the increased light extinction in the hypolimnion continues to be unresolved. The scarce concentrations of SRP in the trophogenic zone coupled with moderate concentrations of available DIN result in large DIN:SRP ratios for Boot Lake. Evidence from nutrient concentrations and ratios suggest that the plankton in Boot Lake are limited by $P$. 
Table 13. Nutrient Concentrations and Ratios and Chlorophyll a Concentrations in Boot Lake (8-15-93). Values \pm 1 standard deviation.

\begin{tabular}{|c|c|c|c|c|c|c|c|c|c|c|}
\hline $\begin{array}{l}\text { Depth } \\
\text { (m) }\end{array}$ & $\begin{array}{l}\text { Chl. a } \\
(\mu g /)\end{array}$ & $\begin{array}{l}\text { SRP } \\
(\mu g /)\end{array}$ & $\underset{(\mu g / 1)}{\operatorname{TP}}$ & $\begin{array}{c}\mathrm{NO}_{3}+\mathrm{NO}_{2} \\
(\mu \mathrm{g})\end{array}$ & $\begin{array}{l}\mathrm{NH}_{4} \\
(\mu \mathrm{g} /)\end{array}$ & $\begin{array}{c}\text { TN } \\
(\mu g / 1)\end{array}$ & $\begin{array}{l}\mathrm{SiO}_{2} \\
(\mathrm{mg} /)\end{array}$ & $S R N^{3}: S R P$ & $S R N^{3}: T P$ & TN:TP \\
\hline 1 & $\begin{array}{l}11.0 \\
\pm 0.2\end{array}$ & $\begin{array}{c}0.9 \\
\pm 0.2\end{array}$ & $\begin{array}{l}21.0 \\
\pm 2.2\end{array}$ & $\begin{array}{l}61.2^{1} \\
\pm 8.8\end{array}$ & $\begin{array}{c}1.0 \\
\pm 0.1\end{array}$ & $\begin{array}{r}23.2 \\
\pm 3.7\end{array}$ & $\begin{array}{l}6.6 \\
\pm 0\end{array}$ & $69.6^{1}$ & $3.0^{1}$ & 1.1 \\
\hline 7 & $\begin{array}{l}25.0 \\
\pm 2.0\end{array}$ & $\begin{array}{r}2.7^{1} \\
\pm 2.6\end{array}$ & $\begin{array}{l}15.9 \\
\pm 0.4\end{array}$ & $\begin{array}{l}43.8 \\
\pm 1.9\end{array}$ & $\begin{array}{l}1.5 \\
\pm 0.1\end{array}$ & $\begin{array}{l}20.3 \\
\pm 4.0\end{array}$ & $\begin{array}{l}7.0 \\
\pm 0\end{array}$ & $268.6^{1}$ & 2.8 & 1.3 \\
\hline 14.5 & $\begin{array}{l}183.1^{1} \\
\pm 151.8\end{array}$ & $\begin{array}{l}0.7 \\
\pm 0\end{array}$ & $\begin{array}{l}18.1 \\
\pm 1.4\end{array}$ & $\begin{array}{l}91.0 \\
\pm 2.8\end{array}$ & $\begin{array}{c}5.8 \\
\pm 0.4\end{array}$ & $\begin{array}{l}118.7^{1} \\
\pm 15.8\end{array}$ & $\begin{array}{l}7.6 \\
\pm 0\end{array}$ & 131.3 & 5.4 & $6.7^{1}$ \\
\hline
\end{tabular}

${ }^{1}$ Questionable data (standard deviation $>(\text { value })^{1 / 2}$ ) ${ }^{2}$ N.D. No data ${ }^{3} \mathrm{SRN}=\mathrm{NO}_{3}+\mathrm{NO}_{2}+\mathrm{NH}_{4}$

Figure 25. Profiles of Temperature, Oxygen, and Light Attenuation in Boot Lake (8-15-93).
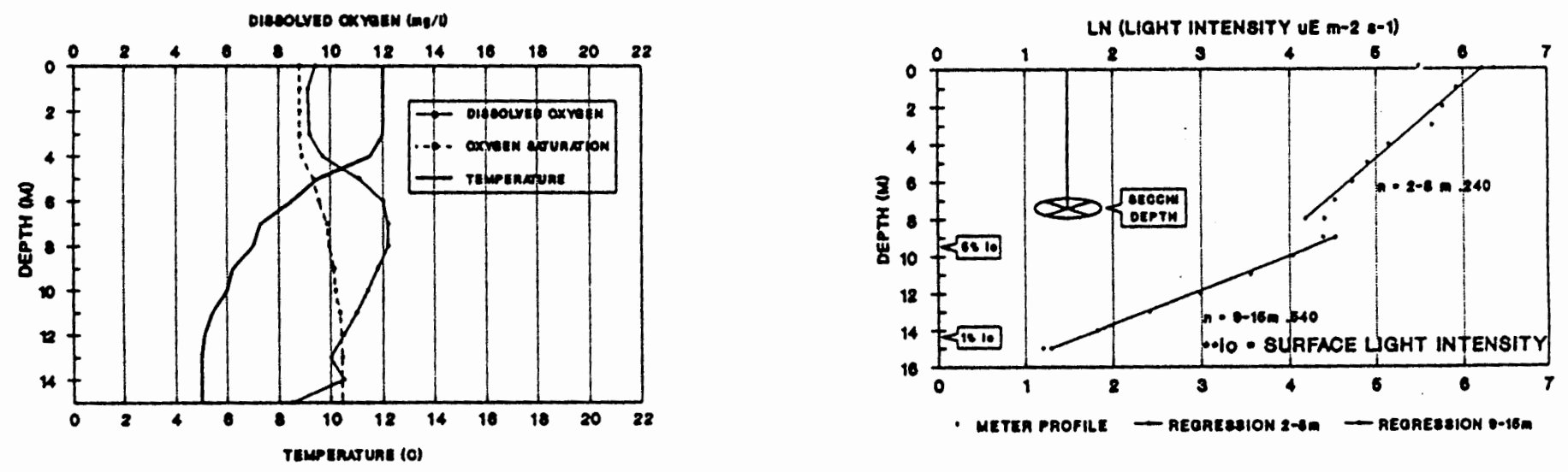


\section{Panhandle Lake}

Panhandle Lake is located in the Mount Margaret backcountry at the headwaters of the Green River, inside the blast zone of Mount St. Helens, $16 \mathrm{~km}$ north of the mountain's crater. This alpine lake is situated in a cirque basin, at an altitude of $1415 \mathrm{~m}$. Because of its protected location beyond Mount Margaret, the lake received less direct inputs from the blast than other lakes in the blast zone, although large trees in the watershed were denuded of their vegetation and blown down, sending large amounts of DOC into the lake. Following the 1980 eruption, the lake had the highest extinction coefficient $\left(16.4 \mathrm{~m}^{-1}\right)$ of all the lakes in this report (Wissmar et al. 1982a), which reflects the dramatic impact the eruption had on the lake. Today the large population of brook trout in the lake appear to be food limited, as they are very small and have unusually large heads. The limited availability of food may be related to the scarcity of available phosphorus in the lake.

\section{Temperature, Oxygen, and Light}

Profiles of temperature, oxygen concentration, and light are presented in Figure 27. Having a maximum depth of $18 \mathrm{~m}$, Panhandle Lake turns over twice each year (dimictic) and develops a thermocline in the summer. In August 1993, surface temperatures reached $13^{\circ} \mathrm{C}$ and the epilimnion extended to a depth of $2 \mathrm{~m}$. At this time, a continuous thermocline penetrated down to $14 \mathrm{~m}$, where temperatures were $4^{\circ} \mathrm{C}$ throughout the hypolimnion. 
Oxygen was saturated in the epilimnion and increased with depth. In August 1993 and August 1994, concentrations of oxygen were elevated at $10 \mathrm{~m}$ depth. Concentrations reached $119 \%$ and $129 \%$ saturation, respectively, suggesting active populations of phytoplankton at this depth. Below $16 \mathrm{~m}$, concentrations of oxygen declined to $5.7 \mathrm{mg} / \mathrm{l}$ (53\% saturation with respect to surface atmospheric pressure) one meter off the bottom. These data suggest that reducing conditions were present in the bottom sediments of the lake.

Water transparency in Panhandle Lake is high, although decreased transparency in the hypolimnion continues to be a characteristic of the lake. Profiles of light intensity reveal a dramatic increase in light attenuation below $10 \mathrm{~m}$. The extinction coefficient was $0.13 \mathrm{~m}^{-1}$ above and $0.26 \mathrm{~m}^{-1}$ below $10 \mathrm{~m}$. Some chemical or biological entity is attenuating the light in the lower half of the lake. A change in extinction coefficient in the deeper portion of the lake has been documented on previous samplings, but has not yet been identified. Further, $1 \%$ surface light intensity was available throughout the water column during the August 1993 sampling.

\section{Nutrient Dynamics}

Concentrations of total and dissolved nutrients, chlorophyll-a and nutrient ratios for Panhandle Lake are presented in Table 14. In August 1993, the average SRP concentration was $0.4 \mu \mathrm{g} /($ (range $0.2-0.6 \mu \mathrm{g} / \mathrm{l})$. Nitrate + nitrite concentrations were high, averaging $65.4 \mu \mathrm{g} /($ (range $30-118 \mu \mathrm{g} /$ ) and ammonium was low, averaging 3.7 $\mu \mathrm{g} /$ (range 1.6 - $6.5 \mu \mathrm{g} /$ ). 
$\mu \mathrm{g} / \mathrm{l}$ (range $1.6-6.5 \mu \mathrm{g} / \mathrm{l})$.

The availability of SRP throughout the water column was limited in Panhandle Lake. The lowest values were in the epilimnion $(1 \mathrm{~m})$, where concentrations were 0.2 $\mu \mathrm{g} / \mathrm{l}$. Ammonium was also depleted in the epilimnion $(1.6 \mu \mathrm{g} / \mathrm{l})$, although substantial oxidized nitrogen was available. The maximum chlorophyll-a concentration $(13.5 \mu \mathrm{g} / \mathrm{l})$ occurred at this depth $(1 \mathrm{~m})$, suggesting assimilation of $\mathrm{N}$ and $\mathrm{P}$ by the phytoplankton.

In August 1993, the concentration of TN $(170.1 \mu \mathrm{g} / \mathrm{l})$, TP $(12.6 \mu \mathrm{g} / \mathrm{l})$, and ammonium $(6.5 \mu \mathrm{g} /)$ were highest in the hypolimnion. Light availability at this depth (18 m) was $2 \%$ surface light intensity which may be below the depth at which the energy gained from photosynthesis meets metabolic requirements (the compensation point) for the phytoplankton. The inability of the phytoplankton to take up nutrients at this depth would result in such nutrient accumulations, particularly during periods of strong thermal stratification (see Figure 27).

Concentrations of Si remained high throughout the year, and was always above 6.0 $\mathrm{mg} / \mathrm{l}$. In 1993, the dominant phytoplankton species in Panhandle Lake were the diatoms Fragilaria crotonensis and Synedra rumpens and the dinoflagellate Glenodinium sp.(Baker 1995). In August 1993, concentrations of Si were lowest in the epilimnion (6.0 $\mathrm{mg} / \mathrm{l}$ ) and increased with increasing depth (up to $7.4 \mathrm{mg} / \mathrm{l}$ in the hypolimnion). This may reflect the dissolution of $\mathrm{Si}$ from the bottom sediments or assimilation and subsequent sedimentation of silicious phytoplankton to the bottom. Because Si is so plentiful in Panhandle Lake, it is doubtful that this nutrient would limit the growth of diatomaceous phytoplankton. 
Nutrient Ratios

In August 1993, N:P ratios for Panhandle Lake were high, indicative of $\mathrm{P}$ limiting conditions. The DIN:SRP for the lake was high at all depths (always above 70), resulting from the limited availability of SRP in the lake. The TN:TP was also elevated, ranging from 28 in the epilimnion to 13.8 in the hypolimnion indicating $\mathrm{P}$ limiting conditions at this time. These ratios suggest severe $P$ limitation in Panhandle Lake.

Bioassays

Alkaline Phosphatase

Data on alkaline

phosphatase enzyme activity (APA) during July 1994 suggest that the plankton community in Panhandle Lake is $\mathbf{P}$ deficient (Figure 26). Plankton collected from $4 \mathrm{~m}$ depth produced a $25 \%$ average (SD 0.8) increase in APA, compared to blank controls. The increase in APA indicates that the

\section{Alkaline Phosphatase Activity}

Panhandle Lake July 1994

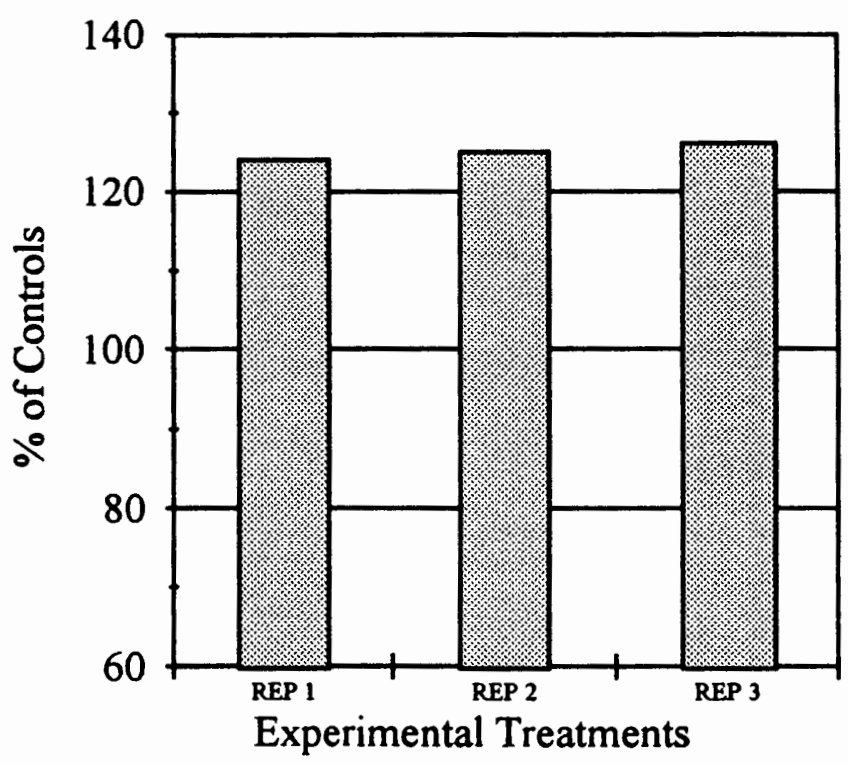


plankton are relatively deficient in $\mathrm{P}$.

\section{Conclusion}

Data collected in 1993 and 1994 suggest that the lake has recovered from the blast and resembles other Cascade lakes in terms of water clarity and nutrient concentrations. The low concentrations of phosphorous appear to limit the productivity of the lake and may also exert a bottom-up control over size of the abundant resident population of Brook trout that live in the lake. The trout are very eager to eat anything presented to them, as a half hour of fly-fishing will attest.

Nutrient concentrations and ratios clearly indicate that $P$ is in relatively shorter supply compared to N in Panhandle Lake. APA further demonstrates that the plankton are allocating energy to obtain additional $\mathbf{P}$, further implicating $\mathbf{P}$ as the limiting nutrient in Panhandle Lake. 
Table 14. Nutrient Concentrations and Ratios and Chlorophyll a Concentrations in Panhandle Lake (8-14-93). Values \pm 1 standard deviation.

\begin{tabular}{|c|c|c|c|c|c|c|c|c|c|c|}
\hline $\begin{array}{l}\text { Depth } \\
\text { (m) }\end{array}$ & $\begin{array}{l}\text { Chl. a } \\
(\mu g / 1)\end{array}$ & $\begin{array}{c}\text { SRP } \\
(\mu g /)\end{array}$ & $\begin{array}{c}\text { TP } \\
(\mu \& \Omega)\end{array}$ & $\begin{array}{c}\mathrm{NO}_{3}+\mathrm{NO}_{2} \\
(\mu \mathrm{g} / \mathrm{l})\end{array}$ & $\begin{array}{l}\mathrm{NH}_{4} \\
(\mu g / \mathcal{I})\end{array}$ & $\begin{array}{c}\text { TN } \\
(\mu \& \Omega)\end{array}$ & $\begin{array}{l}\mathrm{SiO}_{2} \\
(\mathrm{mg} / \mathrm{l})\end{array}$ & $S R N^{3}: S R P$ & $S R N^{3}: T P$ & TN:TP \\
\hline 1 & $\begin{array}{l}13.5 \\
\pm 3.1\end{array}$ & $\begin{array}{c}0.2 \\
\pm 0.2\end{array}$ & $\begin{array}{c}1.7 \\
\pm 1.1\end{array}$ & $\begin{array}{l}118.4^{1} \\
+67.4\end{array}$ & $\begin{array}{l}1.6 \\
\pm 0\end{array}$ & $\begin{array}{l}32.2 \\
\pm 3.7\end{array}$ & $\begin{array}{l}6.0 \\
\pm 0\end{array}$ & $1208.3^{1}$ & $73.5^{1}$ & 28.2 \\
\hline 10 & $\begin{array}{l}11.6 \\
\pm 2.6\end{array}$ & $\begin{array}{c}0.4 \\
\pm 0.3\end{array}$ & $\begin{array}{c}0.9 \\
\pm 0.9\end{array}$ & $\begin{array}{l}47.6 \\
+6.6\end{array}$ & $\begin{array}{c}3.1 \\
\pm 0.2\end{array}$ & $\begin{array}{r}26.9 \\
\pm 4.2\end{array}$ & $\begin{array}{c}6.8 \\
\pm 0.1\end{array}$ & 308.7 & 41.2 & 22.1 \\
\hline 18 & $\begin{array}{l}24.9 \\
\pm 2.8\end{array}$ & $\begin{array}{c}0.6 \\
\pm 0.2\end{array}$ & $\begin{array}{l}12.6 \\
\pm 1.1\end{array}$ & $\begin{array}{l}30.2 \\
\pm 2.9\end{array}$ & $\begin{array}{c}6.5 \\
\pm 0.2\end{array}$ & $\begin{array}{l}170.1^{1} \\
\pm 25.6\end{array}$ & $\begin{array}{c}7.4 \\
\pm 0.1\end{array}$ & 71.1 & 2.9 & $13.8^{1}$ \\
\hline
\end{tabular}

${ }_{1}^{1}$ Questionable data (standard deviation $>(\text { value })^{1 / 2}$ ) ${ }^{2} \mathrm{~N}$.D. No data ${ }^{3} \mathrm{SRN}=\mathrm{NO}_{3}+\mathrm{NO}_{2}+\mathrm{NH}_{4}$

Figure 27. Profiles of Temperature, Oxygen, and Light Attenuation in Panhandle Lake (8-14-93).
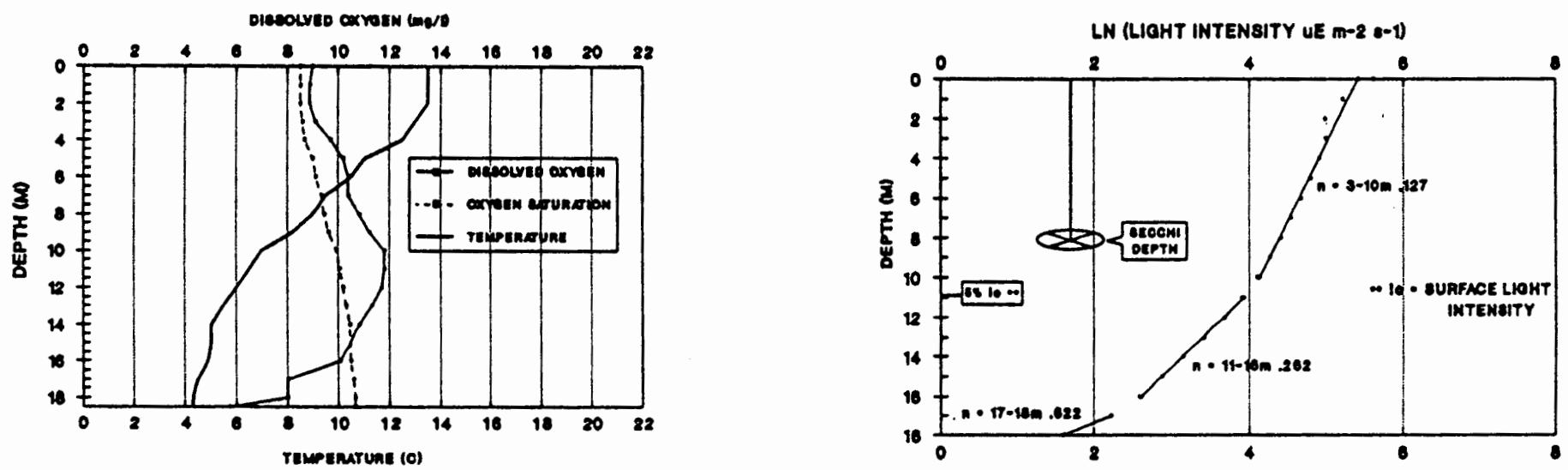


\section{St. Helens Lake}

St. Helens Lake lies in a maar at an elevation of $1405 \mathrm{~m}, 10 \mathrm{~km}$ north of the mountain's crater. The lake is the deepest (>90 m) of all the lakes in this study. The 1980 eruption stripped most of the large trees in the watershed of their vegetation and sent many of them into the lake. As a result, much of the lake remains covered with large logs and woody debris. Although the lake received large amounts of material from the eruption, the impact was lessened because of the large volume of the lake and the small drainage area typical of maar lakes.

\section{Temperature, Oxygen, and Light}

Profiles of temperature, oxygen, and light attenuation for St. Helens Lake (August 1993 data) are presented in Figure 28. In August 1993, St. Helens Lake was stratified and the surface temperature was $14^{\circ} \mathrm{C}$. The thermocline extended from near the surface to 15 m and temperatures in the hypolimnion were $4^{\circ} \mathrm{C}$. These conditions would effectively separate the bottom waters of the lake from the oxygenated surface waters.

Oxygen concentrations in the lake were nearly saturated at the surface and declined steadily below $10 \mathrm{~m}$ (clinograde oxygen curve). Oxygen in the hypolimnion dropped to $3.5 \mathrm{mg} / 1$ at $75 \mathrm{~m}$ ( $32 \%$ saturation). It is possible that logs which have persisted at and below the surface of the lake since the 1980 eruption contribute to the oxygen demand in the bottom waters. The conductivity was higher in the hypolimnion (96 $\mu$ Siemens $\left.\mathrm{cm}^{-1}\right)$ than in the epilimnion $\left(77 \mu\right.$ Siemens $\left.\mathrm{cm}^{-1}\right)$. Increased conductivities in 
the hypolimnion suggest incomplete mixing during periods of circulation. Mixing processes are important in the aeration of the bottom waters.

Water transparency in St. Helens Lake is high. The extinction coefficient was $0.12 \mathrm{~m}^{-1}$, which was the lowest for all the lakes sampled during this study. The Secchi disk depth was $18.3 \mathrm{~m}$ in 1993, but has been as high as $23 \mathrm{~m}$ (1992 data). Light meter readings indicate that $1 \%$ surface light intensity reached $39 \mathrm{~m}$ in 1993 . These data indicate ultraoligotrophic conditions in St. Helens Lake, although the oxygen depletion in the hypolimnion suggests a slightly more productive classification.

\section{Nutrient Dynamics}

Concentrations of total and dissolved nutrients, chlorophyll-a and nutrient ratios for St. Helens Lake are presented in Table 15. In 1993, the SRP concentration was low, averaging $1.4 \mu \mathrm{g} /$ (range $0.1-3.7 \mu \mathrm{g} /$ ). The average nitrate + nitrite concentration was $143.8 \mu \mathrm{g} / \mathrm{l}($ range $121.2 \mu \mathrm{g} / 1-169.7 \mu \mathrm{g} / \mathrm{l})$ and ammonium concentrations averaged 11.9 $\mu \mathrm{g} / \mathrm{l}$ (range $5.0-25.6 \mu \mathrm{g} /$ ).

The availability of SRP throughout the water column was limited in St. Helens Lake and decreased with increasing depth. Concentrations of SRP were $3.7 \mu \mathrm{g} / \mathrm{lat} 1 \mathrm{~m}$ and fell to $0.4 \mu \mathrm{g} / 1$ at $15 \mathrm{~m}$. These scant concentrations of SRP in the lake suggest that plankton growth is limited by $\mathrm{P}$. The concentrations of DNN in the lake were elevated and fairly constant, although the nitrate + nitrite:ammonium ratios decreased with depth. At the surface the nitrate + nitrite concentration was $169.7 \mu \mathrm{g} / \mathrm{l}$, while $5.0 \mu \mathrm{g} / \mathrm{l}$ of ammonium were present. Conversely, ammonium increased considerably in the hypolimnion, reaching 
$25.6 \mu \mathrm{g} / \mathrm{l}$, while nitrate + nitrite declined to $121.3 \mu \mathrm{g} / \mathrm{l}$. Decreased oxygen concentrations in the hypolimnion would favor reduced nitrogen (ammonium) over oxidized nitrogen, (nitrate). These data indicate ample amounts of $\mathrm{N}$ in the lake for plankton growth.

Concentrations of Si were high in St. Helens Lake and were always above 5.7 $\mathrm{mg} / \mathrm{l}$. In 1993, the dominant phytoplankton species in St. Helens Lake was the green algae Ankistrodesmus falcatus and the small flagellate Cryptomonas erosa, although many species of diatoms were also found (Baker 1995). In August 1993, concentrations of Si were lowest in the epilimnion $(5.7 \mathrm{mg} / \mathrm{l})$ and increased slightly with increasing depth (up to $6.1 \mathrm{mg} / 1$ at $75 \mathrm{~m}$ ). This may reflect assimilation of Si and sedimentation of silicious phytoplankton toward the bottom. Because Si is so plentiful in St. Helens Lake, it is doubtful that this nutrient would limit the growth of silicious phytoplankton.

In August 1993, the chlorophyll-a concentration was $39.9 \mu \mathrm{g} /$ in the epilimnion $(1$ $\mathrm{m})$ where SRP and TN concentrations were also at a maximum $(3.7$ and $121.9 \mu \mathrm{g} /$, respectively). Chlorophyll-a concentrations decreased with depth to $21.6 \mu \mathrm{g} / \mathrm{l}$ at $15 \mathrm{~m}$ and $9.0 \mu \mathrm{g} / \mathrm{lat} 75 \mathrm{~m}$. Limited SRP availability at $15 \mathrm{~m}$ may limit the growth of the phytoplankton, as sufficient light was present for photosynthesis ( $5 \%$ surface light intensity was available at $25 \mathrm{~m}$ ). In 1991, Phytoplankton densities in the lake were low $(30$ cells $/ \mathrm{ml})$ and indicate oligotrophic conditions in the lake.

\section{Nutrient Ratios}

Nutrient ratios for St. Helens Lake during August 1993 clearly indicate P limitation. The abundant $\mathbf{N}$ availability coupled with low SRP concentrations throughout 
the lake resulted in high DIN:SRP ratios (range 52.5 - 1791). The DIN:SRP ratio was 52.5 in the epilimnion $(1 \mathrm{~m})$, where the chlorophyll-a concentration was the highest (39.9 $\mu \mathrm{g} / \mathrm{l})$. TN:TP ratios in St. Helens Lake always exceeded 110 and further suggest $P$ as the limiting nutrient.

\section{Conclusion}

Physical and chemical conditions in St. Helens Lake indicate oligotrophic conditions. The paucity of SRP in the lake results in low phytoplankton abundance, which is confirmed by high water transparency and deep Secchi Disk depths. Evidence from nutrient concentrations and ratios suggest that the plankton in St. Helens Lake are limited in their growth by P. Decreased oxygen and elevated conductivities suggests incomplete mixing during circulation. The great depth and protected location of the lake basin reduces the wind action on the lake and may prevent full circulation. The large volume and small drainage area results in a long residence time and makes the return to preeruption conditions particularly slow for St. Helens Lake. 
Table 15. Nutrient Concentrations and Ratios and Chlorophyll a Concentrations in St. Helens Lake (8-10-93). Values \pm 1 standard deviation.

\begin{tabular}{|c|c|c|c|c|c|c|c|c|c|c|}
\hline $\begin{array}{l}\text { Depth } \\
\text { (m) }\end{array}$ & $\begin{array}{l}\text { Chl. a } \\
(\mu g /)\end{array}$ & $\begin{array}{l}\text { SRP } \\
(\mu g / 1)\end{array}$ & $\begin{array}{c}\mathrm{TP} \\
(\mu g /)\end{array}$ & $\begin{array}{c}\mathrm{NO}_{3}+\mathrm{NO}_{2} \\
(\mu \mathrm{g} /)\end{array}$ & $\begin{array}{l}\mathrm{NH}_{4} \\
(\mu g \mathcal{N})\end{array}$ & $\begin{array}{c}\text { TN } \\
(\mu g /)\end{array}$ & $\begin{array}{l}\mathrm{SiO}_{2} \\
(\mathrm{mg} / \mathrm{l})\end{array}$ & $S R N^{3}: S R P$ & $S R N^{3}: T P$ & TN:TP \\
\hline 1 & $\begin{array}{l}39.9^{1} \\
\pm 17.6\end{array}$ & $\begin{array}{r}3.7 \\
\pm 1.0\end{array}$ & $\begin{array}{l}0.0^{1} \\
\pm 0\end{array}$ & $\begin{array}{l}169.7^{1} \\
\pm 18.6\end{array}$ & $\begin{array}{c}5.0 \\
\pm 0.2\end{array}$ & $\begin{array}{l}121.9 \\
\pm 2.1\end{array}$ & $\begin{array}{l}5.7 \\
\pm 0\end{array}$ & $52.5^{1}$ & $174.6^{1}$ & $121.8^{1}$ \\
\hline 15 & $\begin{array}{l}21.6^{1} \\
\pm 7.8\end{array}$ & $\begin{array}{l}0.4 \\
\pm 0\end{array}$ & $\begin{array}{l}0.0^{1} \\
\pm 0\end{array}$ & $\begin{array}{l}140.4 \\
\pm 3.6\end{array}$ & $\begin{array}{c}5.2 \\
\pm 0.5\end{array}$ & $\begin{array}{l}110.2 \\
\pm 1.6\end{array}$ & $\begin{array}{l}5.7 \\
\pm 0\end{array}$ & 355.6 & 145.6 & $110.2^{1}$ \\
\hline
\end{tabular}

${ }^{1}$ Questionable data (standard deviation $>(\text { value })^{1 / 2}$ ) ${ }^{2} \mathrm{~N} . \mathrm{D}$. No data ${ }^{3} \mathrm{SRN}=\mathrm{NO}_{3}+\mathrm{NO}_{2}+\mathrm{NH}_{4}$

Figure 28. Profiles of Temperature, Oxygen, and Light Attenuation in St. Helens Lake (8-10-93).
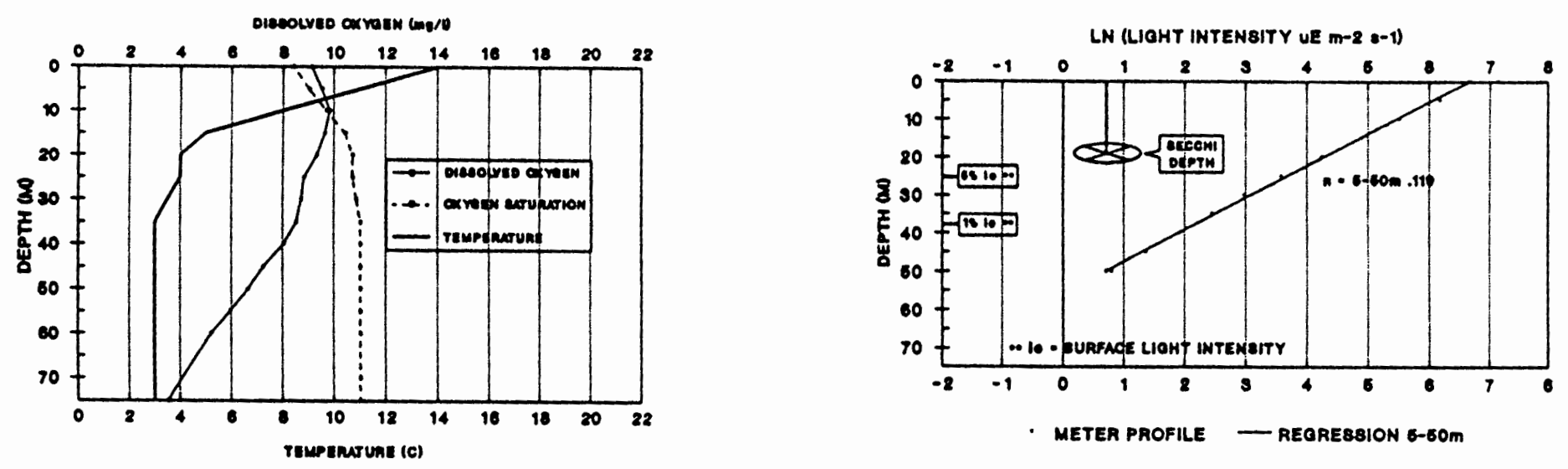


\section{Venus Lake}

Venus Lake lies in a cirque basin at an elevation of $1415 \mathrm{~m}, 16 \mathrm{~km}$ north of the mountain's crater at the northern edge of the blast zone. Numerous large trees in the watershed were denuded of their vegetation, and some large trees were thrown into the lake, although several small trees near the lake survived the blast, finding refuge under the snow. Snow was also present in shaded portions around the lake during the August 1993 sampling.

Having a depth of $39 \mathrm{~m}$, Venus Lake is the second deepest lake in this report. The large volume of this lake diluted the inputs and reduced the effects from the blast. Because of its protected location beyond Mount Margaret, the lake received less direct inputs from the blast than other lakes in the blast zone, although pre-eruption conductivity data suggest that the lake was substantially affected by the 1980 enuption. The specific conductance was $223 \mu \mathrm{S} / \mathrm{cm}$ in 1980 (compared to $9 \mu \mathrm{S} / \mathrm{cm}$ in 1974) (Dion and Embry 1981). Following the eruption, total alkalinities $(24 \mu \mathrm{eq} / \mathrm{l})$ and concentrations of silica (3 $\mathrm{mg} / \mathrm{l}$ ) were slightly elevated, although values were the lowest of all the lakes sampled in this study (Wissmar et al. 1982a).

\section{Temperature, Oxygen, and Light}

Profiles of temperature, oxygen, and light attenuation for Venus Lake are presented in Figure 31. Having a maximum depth of $39 \mathrm{~m}$, Venus Lake stratifies in the summer. In August 1993, the thermocline extended from 3 to $9 \mathrm{~m}$, effectively separating 
the epilimnion from the bottom waters. Temperatures were $14 \mathrm{C}$ at the surface and $4 \mathrm{C}$ in the hypolimnion.

In August 1993 and September 1994, oxygen concentrations were elevated at 5 and $12 \mathrm{~m}$, respectively. Respective oxygen concentrations reached $110 \%$ and $115 \%$ saturation, suggesting phytoplankton activity at these depths. In the lower hypolimnion, however, a clinograde oxygen curve developed and oxygen levels declined to $3.6 \mathrm{mg} / \mathrm{l}$ (33\% saturation). These conditions suggest that reducing conditions were present in the bottom sediments. Logs which have persisted at and below the surface of the lake since the 1980 eruption may contribute to the oxygen depletion in the lake.

Water transparency in Venus Lake is high. In August 1993, the extinction coefficient was $0.14 \mathrm{~m}^{-1}$ and the Secchi disk depth was $16.5 \mathrm{~m}$. These values are closely similar to those obtained in 1991 when the extinction coefficient was $0.15 \mathrm{~m}^{-1}$ and the Secchi disk depth was $12.7 \mathrm{~m}$ (Petersen 1993). In 1993, the extinction coefficient was slightly greater near the surface $\left(0.14 \mathrm{~m}^{-1}\right.$ above $\left.5 \mathrm{~m}\right)$ compared to below $5 \mathrm{~m}\left(0.113 \mathrm{~m}^{-1}\right)$. Increased light attenuation above $5 \mathrm{~m}$ coupled with supersaturated oxygen concentrations indicate that a population of phytoplankton reside in the epilimnion. One percent light intensity was present to a depth of $37 \mathrm{~m}$. These data indicate distinctly oligotrophic conditions in Venus Lake, although the oxygen depletion in the hypolimnion suggests a slightly more productive classification.

\section{Nutrient Dynamics}

Concentrations of total and dissolved nutrients, chlorophyll-a and nutrient ratios 
for Venus Lake are presented in Table 16. The SRP concentration in the lake was low, averaging $2.3 \mu \mathrm{g} / \mathrm{l}($ range $0.8-14.8 \mu \mathrm{g} / \mathrm{l})$. The average nitrate + nitrite concentration was $56.3 \mu \mathrm{g} /($ range $24.8-82.9 \mu \mathrm{g} /$ ) and ammonium concentrations averaged $7.8 \mu \mathrm{g} /$ (range $1.7-16.8 \mu \mathrm{g} / \mathrm{l})$.

Concentrations of SRP during August 1993 were reduced in the epilimnion (1 m) and metalimnion (12 m). SRP concentrations were $0.1 \mu \mathrm{g} / \mathrm{l}$ at both depths, clearly implicating $\mathbf{P}$ as the limiting nutrient. Conversely, DIN was plentiful throughout the water column. The lowest concentration of nitrate + nitrite $(24.8 \mu \mathrm{g} / \mathrm{l})$ and ammonia $(1.7 \mu \mathrm{g} / \mathrm{l})$ occurred at the same depth as the minimum SRP concentrations ( 1 and $12 \mathrm{~m}$ ). Maximum depletion of DIN and SRP occurred at the depth of maximum chlorophyll-a concentration $(45.7 \mu \mathrm{g} / \mathrm{l}$ at $12 \mathrm{~m})$, suggesting nutrient assimilation and growth by the phytoplankton community. Concentrations of TP were extremely low, averaging $2.2 \mu \mathrm{g} /$. These data indicate oligotrophic conditions and provide evidence of $\mathbf{P}$ limitation.

In August 1993, the concentrations of DIN were considerably higher in the bottom waters. The concentration of nitrate + nitrite in the hypolimnion was $82.9 \mu \mathrm{g} /$ and ammonium was $16.8 \mu \mathrm{g} / \mathrm{l}$. The absence of plankton uptake from this depth may produce an accumulation of $\mathrm{N}$ in the deeper waters.

Concentrations of Si were high throughout the water column (always above 4.6 $\mathrm{mg} / \mathrm{l})$. In 1993, the dominant phytoplankton species in Venus Lake were the green alga Crucigenia fenestrata and many diatoms including Fragilaria crotonensis (Baker 1995). Because diatoms are strong competitors when concentrations of SRP are low, they often dominate plankton communities when $\mathrm{N}: \mathrm{P}$ ratios are high, particularly when temperatures 
are below $10 \mathrm{C}$ (Tilman et al. 1986). In August 1993, concentrations of Si were lowest in the epilimnion and metalimnion $(4.6 \mathrm{mg} / \mathrm{l})$ and increased in the hypolimnion $(5.9 \mathrm{mg} / 1)$. This may reflect the dissolution of $\mathrm{Si}$ from the bottom sediments or assimilation of Si and subsequent sedimentation of diatoms to the bottom. Because Si is so plentiful in Venus Lake, it is doubtful that this nutrient would limit the growth of the silicious phytoplankton in the lake.

\section{Nutrient Ratios}

DIN:SRP ratios in August 1993 clearly indicate P limitation in Venus Lake. Abundant DIN and scarce SRP produced high DIN:SRP ratios (above 300) at all depths. DIN:SRP ratios increased with increasing depth, reflecting further increases in the concentrations of DIN toward the bottom. The TN:TP ratios from Venus Lake approximated Redfield values in the epilimnion and metalimnion, suggesting balanced growth at these depths.

\section{Bioassays}

\section{Long Term Enrichment}

Various measures of plankton activity (chlorophyll-a production and carbon fixation) following nutrient addition suggests that the autotrophic and heterotrophic plankton communities in Venus Lake are limited by $\mathrm{P}$, although $\mathrm{N}$ may be co-limiting. 
increase occurred when $\mathbf{P}$ was added, either alone or in combination with $\mathrm{N}$

(Figure 29). The

chlorophyll-a response $(+\mathrm{N}$

$=175 \%,+P=752 \%$ and

$+\mathrm{N} \& \mathrm{P}=890 \%$ of controls $)$,

indicates a synergistic

relationship between $\mathrm{N}$ and

P. Two way analysis of

variance (ANOVA) only

indicated a significant

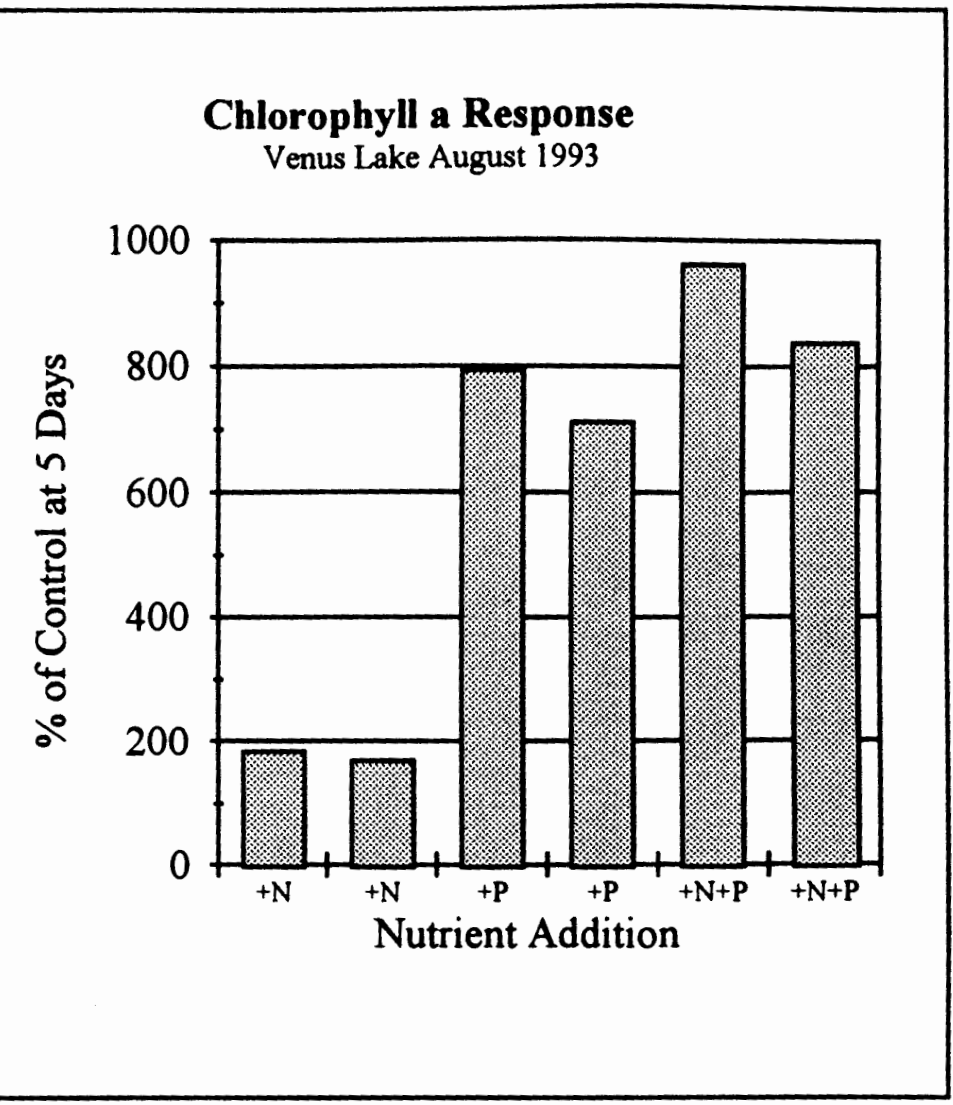

Figure 29

response when $\mathbf{P}$ was

added, either by itself $(P=0.002)$ or in combination with $N(P=0.001)$. Since the addition of $\mathrm{P}$ increased chlorophyll-a four times over $\mathrm{N}$ addition, $\mathrm{P}$ is identified as the primary limiting nutrient in Venus Lake. When $\mathrm{N}$ and $\mathrm{P}$ are added simultaneously, more photosynthetic pigment is produced than with $P$ alone, suggesting additions of $30 \mu \mathrm{g} / \mathrm{P}$ was sufficient to relieve the $P$ limitation.

Carbon fixation in replicate bags given $P$ increased $166 \%$ compared to controls, while no increase occurred when $\mathrm{N}$ was added by itself (Figure 30 ). Treatment with N\&P caused a $157 \%$ increase in carbon fixation compared to controls. Two way analysis of variance (ANOVA) indicates a significant response ( $P \leq 0.001$ ) with the addition of $P$, 
either by itself or in

combination with $\mathrm{N}$.

The addition of $P$

caused a decrease in the

concentration of $\mathrm{N}$ inside the

bags (compared to controls),

which provides evidence for

$P$ limitation. If $P$ was

limiting, the addition of this

nutrient would allow further

growth, which would

stimulate $\mathrm{N}$ uptake.

Concentrations of DIN

Carbon Uptake in the Light

Venus Lake August 1993

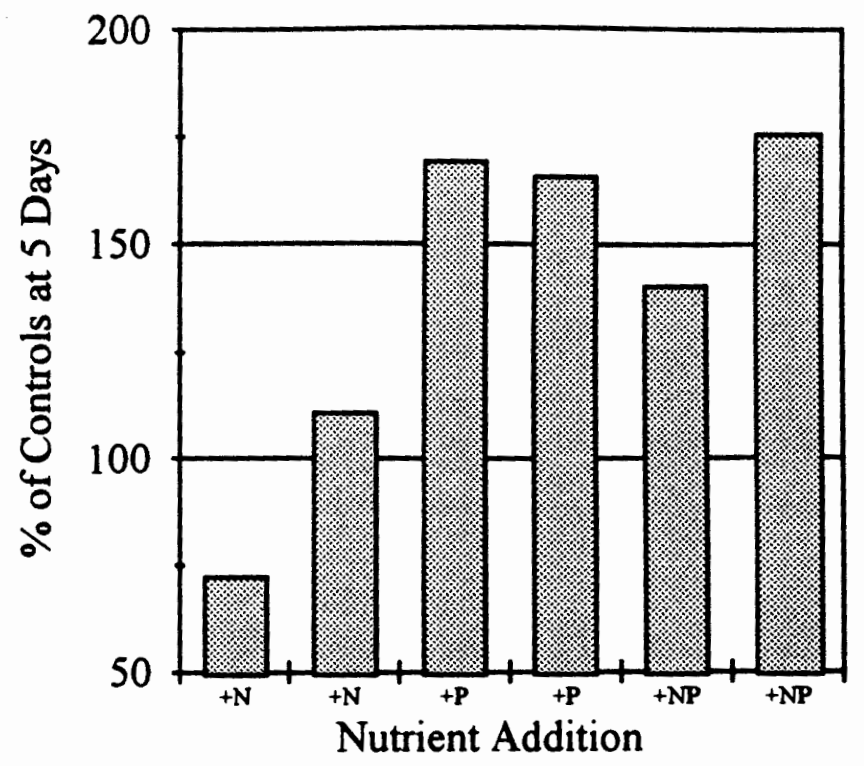

Figure 30

decreased from 49.0 to $29.0 \mu \mathrm{g} /$ with the addition of SRP.

\section{Conclusion}

Data on water transparency and plankton abundance (chlorophyll-a) suggests that Venus Lake has recovered from the 1980 eruption, although the clinograde oxygen profile indicates a considerable oxygen demand in the hypolimnion. Because of the great depth and partially protected location of the lake, inadequate mixing may retard the recovery process by preventing full circulation during fall and spring turnover.

Multiple lines of evidence indicate clearly that $\mathrm{P}$ is the primary limiting nutrient in 
Venus Lake, although there is some indication that $\mathrm{N}$ may limit plankton growth to a much lesser extent. Carbon fixation only increased with the addition of $\mathrm{P}$, either by itself or together with $\mathrm{N}$, providing evidence for $\mathrm{P}$ limitation. Chlorophyll-a production was stimulated by all treatments, although the largest response was found with $\mathrm{P}$, either by itself or in combination with $\mathrm{N}$. The increase in chlorophyll-a with the addition of $\mathrm{N}$ does suggest colimitation by $\mathrm{N}$ and $\mathrm{P}$. The limited availability of SRP in the lake, coupled with large $\mathrm{N}: \mathrm{P}$ values supports evidence from the bioassays that indicates $\mathrm{P}$ as the primary limiting nutrient. 
Table 16. Nutrient Concentrations and Ratios and Chlorophyll a Concentrations in Venus Lake (8-9-93). Values \pm 1 standard deviation.

\begin{tabular}{|c|c|c|c|c|c|c|c|c|c|c|}
\hline $\begin{array}{l}\text { Depth } \\
\text { (m) }\end{array}$ & $\begin{array}{l}\text { Chl. a } \\
(\mu g / 1)\end{array}$ & $\begin{array}{c}\text { SRP } \\
(\mu g / 1)\end{array}$ & $\underset{(\mu g /)}{T P}$ & $\begin{array}{c}\mathrm{NO}_{3}+\mathrm{NO}_{2} \\
(\mu \mathrm{g} /)\end{array}$ & $\begin{array}{l}\mathrm{NH}_{4} \\
(\mu \mathrm{g} /)\end{array}$ & $\begin{array}{c}\mathrm{TN} \\
(\mu \mathrm{g} /)\end{array}$ & $\begin{array}{l}\mathrm{SiO}_{2} \\
(\mathrm{mg} / \mathrm{l})\end{array}$ & SRN'SRP & SRN'TP & TN:TP \\
\hline 1 & $\begin{array}{l}22.9 \\
\pm 0.3\end{array}$ & $\begin{array}{l}0.1 \\
\pm 0\end{array}$ & $\begin{array}{c}1.6 \\
\pm 0.5\end{array}$ & $\begin{array}{l}24.8 \\
\pm 0.4\end{array}$ & $\begin{array}{l}1.7^{1} \\
\pm 1.6\end{array}$ & $\begin{array}{c}9.5 \\
\pm 1.1\end{array}$ & $\begin{array}{l}4.6 \\
\pm 0\end{array}$ & $323.9^{1}$ & $26.5^{1}$ & 7.2 \\
\hline 12 & $\begin{array}{l}45.7 \\
\pm 0.7\end{array}$ & $\begin{array}{l}6.5^{1} \\
\pm 6.4\end{array}$ & $\begin{array}{c}3.0 \\
\pm 0.2\end{array}$ & $\begin{array}{l}61.2 \\
\pm 3.3\end{array}$ & $\begin{array}{c}4.9 \\
\pm 0.6\end{array}$ & $\begin{array}{l}19.5 \\
\pm 3.7\end{array}$ & $\begin{array}{l}4.6 \\
\pm 0\end{array}$ & $429.6^{1}$ & 66.1 & 6.4 \\
\hline 38 & $\begin{array}{l}15.9 \\
\pm 2.4\end{array}$ & $\begin{array}{c}0.4 \\
\pm 0.3\end{array}$ & $\begin{array}{l}2.1 \\
\pm 0\end{array}$ & $\begin{array}{l}82.9 \\
\pm 3.9\end{array}$ & $\begin{array}{l}16.8 \\
\pm 0.6\end{array}$ & $\begin{array}{l}52.0 \\
+2.4\end{array}$ & $\begin{array}{l}5.9 \\
\pm 0\end{array}$ & 701.1 & 99.8 & 24.7 \\
\hline
\end{tabular}

${ }_{1}^{1}$ Questionable data (standard deviation $>\left(\right.$ value) ${ }^{1 / 2}$ ) ${ }^{2}$ N.D. No data ${ }^{3} \mathrm{SRN}=\mathrm{NO}_{3}+\mathrm{NO}_{2}+\mathrm{NH}_{4}$

Figure 31. Profiles of Temperature, Oxygen, and Light Attenuation in Venus Lake (8-9-93).
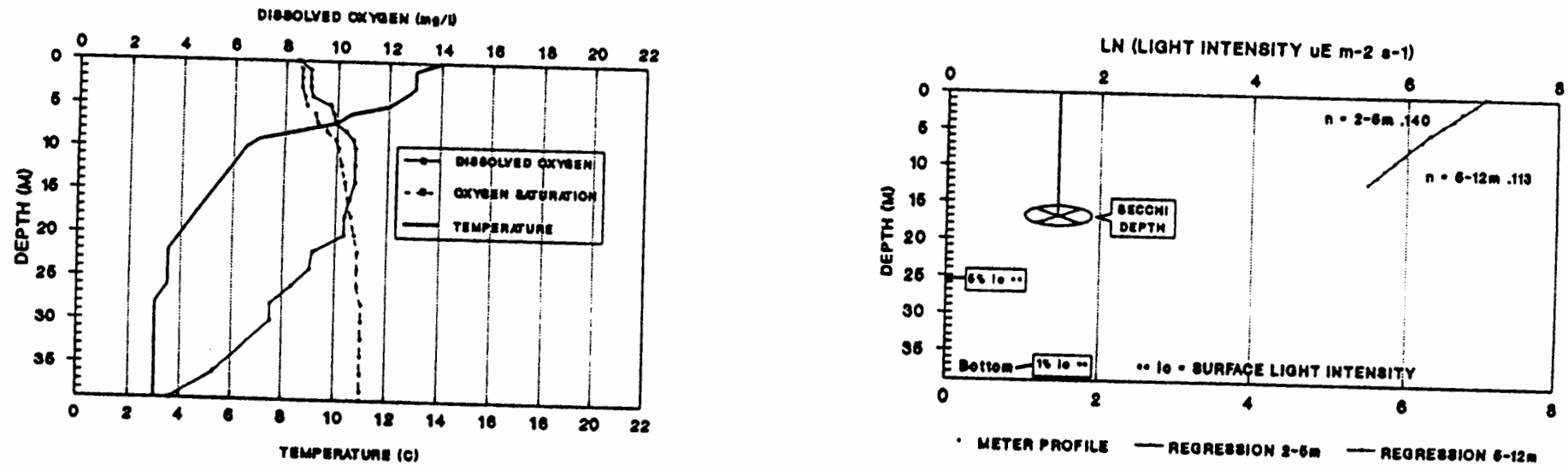


\section{Castle Lake}

The May 18, 1980 eruption of Mount St. Helens melted snow and ice on the mountain, creating mud flows (lahars) which flowed down the South Fork of the Toutle River. Debris avalanche deposits inundated the South Castle Creek drainage, creating a lake basin. As a result, the marsh behind the debris dam began filling up, creating Castle Lake. This newly formed lake lies on the northwest flank of the mountain, at an elevation of $740 \mathrm{~m}, 5 \mathrm{~km}$ from the mountain's crater. Before the eruption, the Castle Creek River watershed contained Douglas fir, Western hemlock, and Western redcedar trees. The blast pyrolyzed the forest, depositing large amounts of DOC into the lake watershed. Castle Lake and two other lakes heavily influenced by the massive mudflows (Spirit and newly formed Coldwater Lakes) had the highest total alkalinities (ca. $4500 \mu \mathrm{eq} / \mathrm{l}$ ) and the lowest $\mathrm{pH}$ values (ca. 6.17) following the blast (Wissmar et al. 1982a). Dissolved oxygen concentrations in the lake decreased steadily throughout 1981, although persistent anaerobic conditions were found only below $10 \mathrm{~m}$. Dominant biological processes in the lake in the two years following the eruption included anaerobic $\mathrm{N}_{2}$ fixation, denitrification, methanogenesis, and sulfate reduction (Ward et al. 1983).

\section{Temperature, Oxygen, and Light}

Profiles of temperature, oxygen, and light attenuation for Castle Lake are presented in Figures 33-36. Having a maximum depth of $32 \mathrm{~m}$, Castle Lake stratifies during summer months. In 1993, the lake had a well defined thermocline which effectively 
separated the hypolimnion from the oxygenated surface water. As a result, oxygen became depleted in the bottom waters. In June 1993, surface temperatures were cool $\left(16^{\circ} \mathrm{C}\right)$ and the thermocline extended from 2 to $10 \mathrm{~m}$. Below the thermocline, oxygen decreased steadily (clinograde oxygen curve) down to $6 \mathrm{mg} / \mathrm{l}$ (52\% saturation). In September 1993, surface temperature were again $\operatorname{cool}\left(16^{\circ} \mathrm{C}\right)$ and the thermocline extended from 8 to $12 \mathrm{~m}$. At this time, a similar pattern of oxygen depletion was present, and concentrations in the hypolimnion decreased to below $1 \mathrm{mg} / 1$ ( $6 \%$ saturation). These concentrations of oxygen indicate reducing conditions in the bottom sediments. Previous oxygen profiles taken from Castle Lake 1991 indicate a substantial areal oxygen deficit (450 $\mathrm{mg} \mathrm{O}_{2} \mathrm{~m}^{-1}$ day $\left.^{-1}\right)($ Kelly 1992). Data from 1993 continue to show a high oxygen demand in the hypolimnion. Hydrocasts made at two stations in the lake produced similar patterns of temperature and oxygen distribution. These data suggest a eutrophic classification for Castle Lake.

Water transparency in Castle Lake is high. During 1993, the average extinction coefficient was $0.36 \mathrm{~m}^{-1}$ (range $0.29-0.50 \mathrm{~m}^{-1}$ ) and the Secchi disk depths ranged from $7.3 \mathrm{~m}$ to $7.9 \mathrm{~m}$. These extinction coefficients are less than those in $1991\left(0.76 \mathrm{~m}^{-1}\right)$, indicating that the water is becoming more transparent (Petersen 1993). Profiles of light intensity reveal a dramatic increase in light attenuation below $8 \mathrm{~m}$. In June 1993, the extinction coefficient was $0.30 \mathrm{~m}^{-1}$ above and $0.50 \mathrm{~m}^{-1}$ below $8 \mathrm{~m}$. Some chemical or biological entity is attenuating the light in the lower half of the lake. A change in extinction coefficient in the deeper portion of the lake has been documented on previous samplings, but has not yet been identified. The depth of $1 \%$ light intensity varied between 
10 and $15 \mathrm{~m}$ during this study. Light attenuation data for the lake indicate oligotrophic conditions, although oxygen data suggests more eutrophic conditions.

\section{Nutrient Dynamics}

Concentrations of total and dissolved nutrients, chlorophyll-a and nutrient ratios for Castle Lake are presented in Tables 17-20. During two samplings in 1993, the average SRP concentration was $7.8 \mu \mathrm{g} / 1$ (range $3.0-30.0 \mu \mathrm{g} / \mathrm{l}$ ). The average nitrate + nitrite concentration was $32.58 \mu \mathrm{g} /$ (range $2.2-80.0 \mu \mathrm{g} /$ ) and ammonium concentrations averaged $36 \mu \mathrm{g} / 1$ (range $2.0-95 \mu \mathrm{g} / \mathrm{l})$.

Concentrations of DIN and SRP at station 1 during summer months, indicate depletion of these nutrients from the photic zone (0 - $10 \mathrm{~m}$ depth). Maximum depletion of DIN and SRP occurred at the depth of maximum chlorophyll-a concentration $(39.0 \mu \mathrm{g} / \mathrm{l}$ at $10 \mathrm{~m}$ ), suggesting nutrient assimilation and growth by the phytoplankton community. From June to September 1993, the concentrations of nitrate + nitrite declined from 41.7 to $2.2 \mu \mathrm{g} / \mathrm{l}$, as did ammonium (from 7.3 to $2.0 \mu \mathrm{g} / \mathrm{l}$ ). SRP in the metalimnion also declined slightly from 5.8 to $4.9 \mu \mathrm{g} / \mathrm{l}$. The uptake and assimilation of DIN and SRP by photosynthesizing phytoplankton may deplete these nutrients to limiting concentrations.

In June 1993, the concentration of nitrate + nitrite in the hypolimnion from station 1 was $79.9 \mu \mathrm{g} / \mathrm{l}$ and ammonium was $76.5 \mu \mathrm{g} / \mathrm{l}$. Nutrients often accumulate in the bottom waters if light intensities are insufficient to support photosynthesis. The anoxic conditions which were present in the hypolimnion at this time would favor reduced nitrogen (ammonium) over nitrate, (oxidized nitrogen). As the growing season progressed into 
September 1993, oxygen concentrations in the hypolimnion declined further and ammonium concentrations increased to $152.0 \mu \mathrm{g} /$, while nitrate+nitrite decreased to 25.7 $\mu \mathrm{g} / 1$. This phenomenon was less pronounced at station 2 , which had slightly more oxygen in the hypolimnion. In September 1993, the concentration of SRP increased from 6.4 to $29.9 \mu \mathrm{g} / \mathrm{in}$ the hypolimnion. It is interesting to note that the highest chlorophyll-a concentration for Castle Lake $(39.0 \mu \mathrm{g} / \mathrm{l})$ occurred during this period of abundant ammonium and SRP in the hypolimnion, suggesting that both $\mathrm{N}$ and $\mathrm{P}$ were required to stimulate growth.

Concentrations of Si remained high throughout the year, and was always above 7.8 mg/l. In 1993, the dominant phytoplankton species in Castle Lake were a Chlamydomonas-like green algae, the dinoflagellate Glenodinium, and the flagellated species Cryptomonas erosa. Some species which use substantial amounts of $\mathrm{Si}$ (Dinobryon sp. and the diatom Achnanthes minutissim) were also identified in the lake (Baker 1995). In August 1993, concentrations of Si were lowest in the metalimnion (9.5 $\mathrm{mg} / \mathrm{l})$, and occurred simultaneously with the maximal chlorophyll-a concentration (39.0 $\mu \mathrm{g} / \mathrm{l})$. Because $\mathrm{Si}$ is so plentiful in Castle Lake, it is doubtful that this nutrient would limit the growth of the diatomaceous phytoplankton in the lake.

\section{Nutrient Ratios}

DIN:SRP ratios for Castle Lake during 1993 differ with respect to both sampling date and depth. In June 1993, the DIN:SRP ratio in the upper water was near the Redfield ratio of 7.2 and suggests balanced nutrient availability. DIN:SRP ratios were 
highest in the hypolimnetic samples, resulting from the elevated concentrations of DIN. Sufficient concentrations of both $\mathrm{N}$ and $\mathbf{P}$ would preclude limitation by either nutrient at this time. In September 1993, however, the DIN:SRP ratios were 0.9 and 1.5 in the metalimnion and epilimnion, respectively. These values clearly indicate limitation by $\mathrm{N}$, although the SRP concentration of $3.0 \mu \mathrm{g} / \mathrm{l}$ in the epilimnion provides evidence for possible colimitation by $\mathrm{N}$ and P. In September 1993, the TN:TP ratios were 2.1 and 2.0 in the metalimnion and epilimnion, respectively, further indicating $\mathrm{N}$ limitation in Castle Lake.

Bioassays

\section{Long Term Enrichment}

Measures of carbon

fixation following nutrient addition of 201 polyethylene bags suggests that both $\mathrm{N}$ and P limit the productivity (growth) of the phytoplankton and heterotrophic organisms (e.g. bacteria) in Castle Lake.

Carbon fixation in

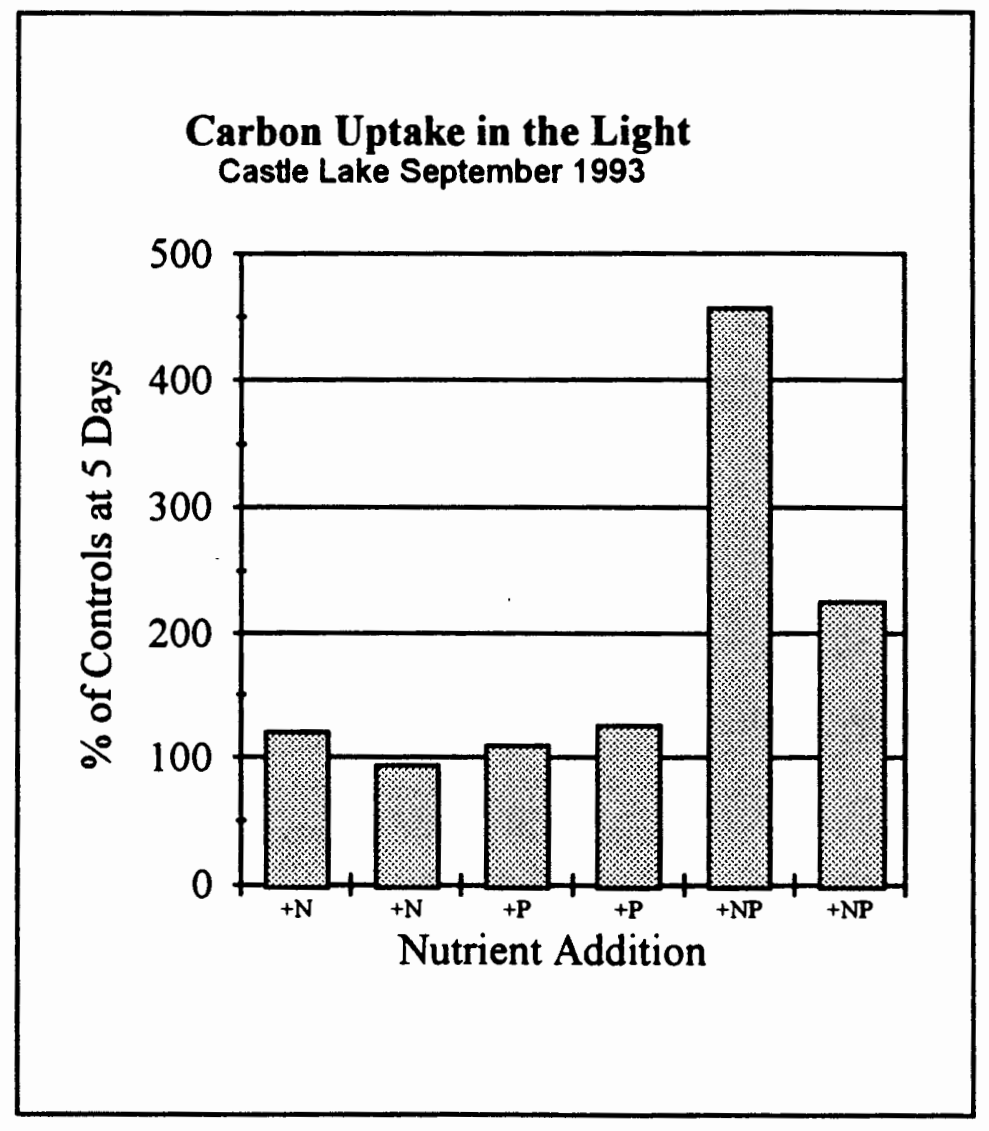

Figure 32 
replicate bags given N\&P increased $340 \%$ compared to controls, while no increase occurred when either $\mathrm{N}$ or $\mathrm{P}$ was added alone (Figure 32). Two way analysis of variance (ANOVA) indicates a significant response $(P=0.001)$ with the simultaneous addition of $\mathrm{N}$ and $\mathrm{P}$, but not with $\mathrm{N}$ or $\mathrm{P}$ alone.

Replicate bags given N\&P showed a greater decrease in the concentration of ammonium in bags given N\&P compared to single additions of $N$. If $P$ was limiting the growth of the plankton, addition of this nutrient would stimulate further $\mathrm{N}$ uptake with subsequent increase in carbon fixation. SRP concentrations did not decrease in bags given $N \& P$ compared to $N$ treatments, which suggests that $P$ is the primary limiting nutrient in Castle Lake. The importance of $\mathrm{N}$ as the limiting nutrient should not be disregarded because planktonic regeneration of $\mathrm{P}$ and alkaline phosphatase activity (APA) can supply significant amounts of $P$ for growth (Dodds et al. 1991; Boni et al. 1989). Unfortunately, APA was not determined for Castle Lake. Chlorophyll-a data were highly variable and showed no consistent pattern.

\section{Conclusion}

Nutrient addition experiments indicate that $\mathrm{N}$ and $\mathrm{P}$ limit the growth of the plankton in Castle Lake. Nutrient uptake following fertilization suggests that $P$ is the primary limiting nutrient, while $\mathrm{N}$ co-limits productivity. Conversely, evidence from nutrient depletion from the water column and nutrient ratios during stratification implicate $\mathrm{N}$ as the primary limiting nutrient in Castle Lake, although low levels of SRP suggest colimitation by $\mathrm{N}$ and $\mathrm{P}$. 
Table 17. Nutrient Concentrations and Ratios and Chlorophyll a Concentrations in Castle Lake, Station 1 (6-26-93).

Values \pm 1 standard deviation.

\begin{tabular}{|c|c|c|c|c|c|c|c|c|c|c|}
\hline $\begin{array}{l}\text { Depth } \\
\text { (m) }\end{array}$ & $\begin{array}{l}\text { Chl. a } \\
(\mu g / 1)\end{array}$ & $\begin{array}{c}\text { SRP } \\
(\mu g / 1)\end{array}$ & $\underset{(\mu g / 1)}{\operatorname{TP}}$ & $\begin{array}{c}\mathrm{NO}_{1}+\mathrm{NO}_{2} \\
(\mu g / 1)\end{array}$ & $\begin{array}{l}\mathrm{NH}_{4} \\
(\mu \mathrm{g} /)\end{array}$ & $\begin{array}{c}\text { TN } \\
(\mu g /)\end{array}$ & $\begin{array}{l}\mathrm{SiO}_{2} \\
(\mathrm{mg} / \mathrm{l})\end{array}$ & SRN':SRP & SRN:TP & TN:TP \\
\hline 1 & $\begin{array}{l}31.9 \\
\pm 0.8\end{array}$ & 5.5 & 3.6 & 31.7 & 6.3 & 62.2 & 7.9 & 6.9 & 10.7 & 17.5 \\
\hline 8 & $\begin{array}{c}9.3 \\
\pm 0.5\end{array}$ & 5.8 & N.D. ${ }^{2}$ & 41.7 & 7.3 & 56.5 & 7.8 & 8.4 & 1.5 & 1.7 \\
\hline 29 & $\begin{array}{r}17.2 \\
\pm 3.9\end{array}$ & 6.4 & 9.0 & 79.9 & 76.5 & 118.7 & 7.9 & 24.4 & 17.4 & 13.2 \\
\hline
\end{tabular}

${ }^{2}$ N.D. No data ${ }^{3} \mathrm{SRN}=\mathrm{NO}_{3}+\mathrm{NO}_{2}+\mathrm{NH}_{4}$

Figure 33. Profiles of Temperature, Oxygen, and Light Attenuation in Castle Lake, Station 1 (6-26-93).
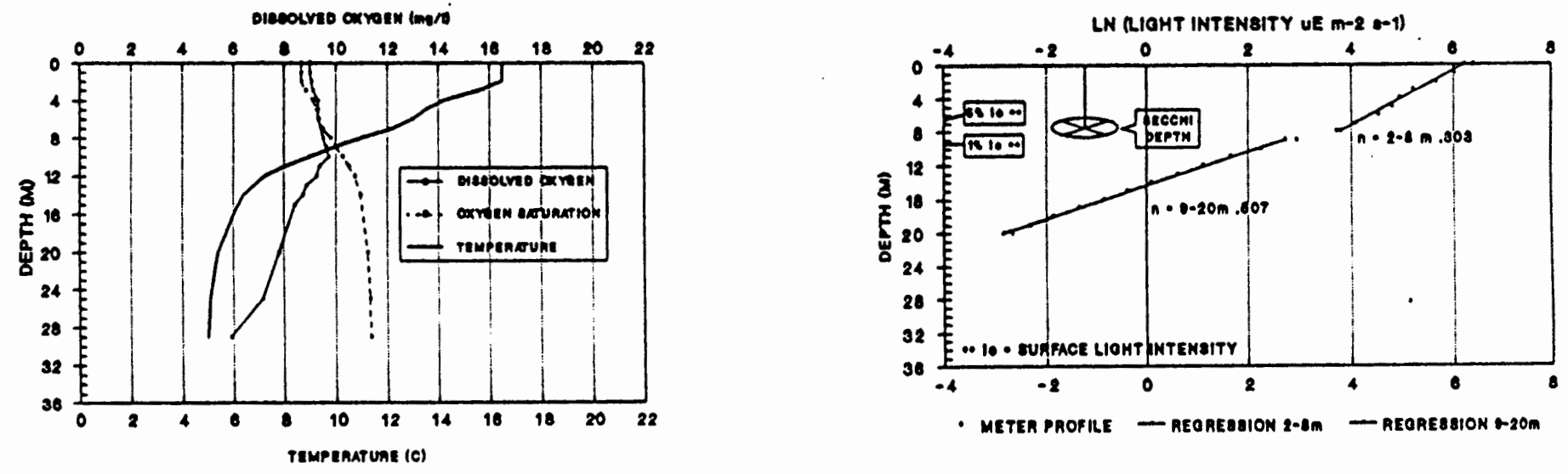
Table 18. Nutrient Concentrations and Ratios and Chlorophyll a Concentrations in Castle Lake, Station 2 (6-26-93).

Values \pm 1 standard deviation.

\begin{tabular}{|c|c|c|c|c|c|c|c|c|c|c|}
\hline $\begin{array}{l}\text { Depth } \\
(\mathrm{m})\end{array}$ & $\begin{array}{l}\text { Chl. a } \\
(\mu g /)\end{array}$ & $\begin{array}{c}\text { SRP } \\
(\mu g /)\end{array}$ & $\begin{array}{c}\mathrm{TP} \\
(\mu \mathrm{g} /)\end{array}$ & $\begin{array}{c}\mathrm{NO}_{3}+\mathrm{NO}_{2} \\
(\mu \mathrm{g} /)\end{array}$ & $\begin{array}{l}\mathrm{NH}_{4} \\
(\mu \mathrm{g} /)\end{array}$ & $\begin{array}{c}\mathrm{TN} \\
(\mu g /)\end{array}$ & $\begin{array}{l}\mathrm{SiO}_{2} \\
(\mathrm{mg} / \mathrm{l})\end{array}$ & $S R N^{3}: S R P$ & $S R N^{3}: T P$ & TN:TP \\
\hline 1 & $\begin{array}{l}25.1^{1} \\
\pm 20.3\end{array}$ & 5.8 & 6.1 & 41.2 & 4.5 & 45.9 & 7.9 & 8 & 7.6 & 17.5 \\
\hline 8 & $\begin{array}{l}29.1^{1} \\
\pm 20.6\end{array}$ & 6.1 & 6.5 & 60.1 & 5.3 & 68.6 & 8.1 & 10.8 & 10.2 & 10.6 \\
\hline 25 & $\begin{array}{l}20.6 \\
\pm 2.9\end{array}$ & 6.1 & 8.3 & 57.4 & 28.7 & 109.2 & 8.1 & 14.1 & 10.4 & 13.2 \\
\hline
\end{tabular}

${ }^{1}$ Questionable data (standard deviation $>\left(\right.$ value) ${ }^{1 / 2}$ ) ${ }^{2} \mathrm{~N} . \mathrm{D}$. No data ${ }^{3} \mathrm{SRN}=\mathrm{NO}_{3}+\mathrm{NO}_{2}+\mathrm{NH}_{4}$

Figure 34. Profiles of Temperature and Oxygen in Castle Lake, Station 1, and Light Attenuation in Castle Lake, Station 1 (6-26-93).
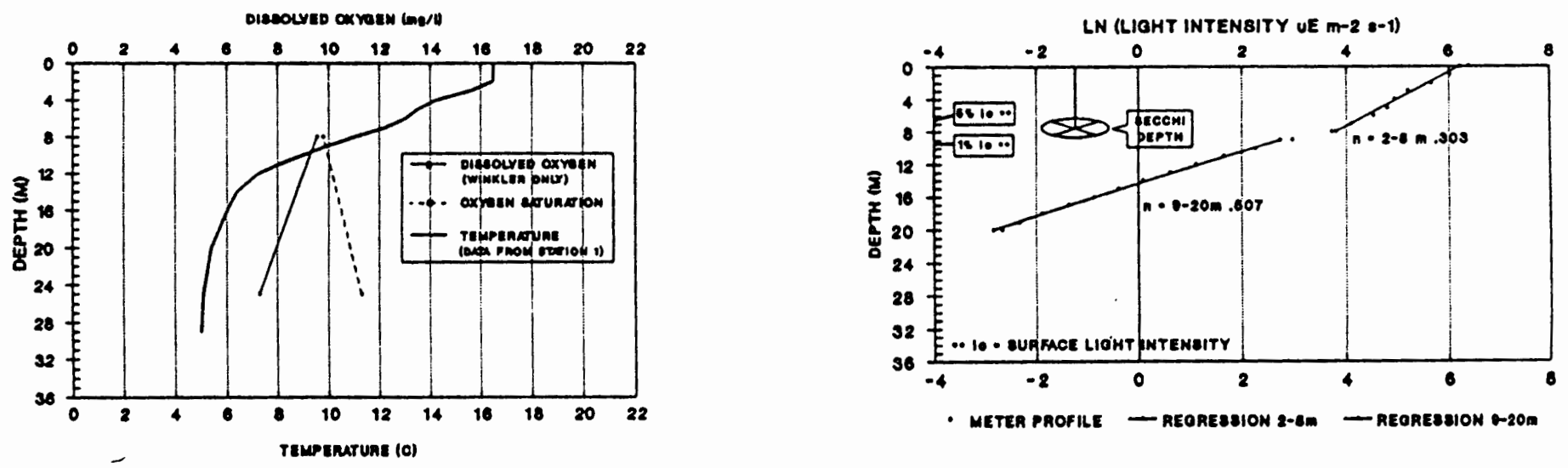
Table 19. Nutrient Concentrations and Ratios and Chlorophyll a Concentrations in Castle Lake, Station 1 (9-17-93).

Values \pm 1 standard deviation.

\begin{tabular}{|c|c|c|c|c|c|c|c|c|c|c|}
\hline $\begin{array}{l}\text { Depth } \\
\text { (m) }\end{array}$ & $\begin{array}{l}\text { Chl. a } \\
(\mu g / 1)\end{array}$ & $\begin{array}{l}\text { SRP } \\
(\mu g / 1)\end{array}$ & $\begin{array}{c}\text { TP } \\
(\mu g / 1)\end{array}$ & $\begin{array}{c}\mathrm{NO}_{3}+\mathrm{NO}_{2} \\
(\mu \mathrm{g} /)\end{array}$ & $\begin{array}{l}\mathrm{NH}_{4} \\
(\mu \mathrm{g} /)\end{array}$ & $\begin{array}{c}\text { TN } \\
(\mu g /)\end{array}$ & $\begin{array}{l}\mathrm{SiO}_{2} \\
(\mathrm{mg} / \mathrm{l})\end{array}$ & SRN:SRP & $S R N^{3}: T P$ & TN:TP \\
\hline 1 & $\begin{array}{l}30.9 \\
\pm 5.4\end{array}$ & $\begin{array}{c}3.0 \\
\pm 0.4\end{array}$ & $\begin{array}{l}24.6 \\
\pm 2.5\end{array}$ & $\begin{array}{c}2.4 \\
\pm 0.6\end{array}$ & $\begin{array}{c}3.7 \\
\pm 0.3\end{array}$ & $\begin{array}{l}47.5 \\
\pm 0.5\end{array}$ & $\begin{array}{c}9.8 \\
\pm 0.2\end{array}$ & 2.1 & 0.2 & 2.0 \\
\hline 10 & $\begin{array}{l}39.0 \\
\pm 3.2\end{array}$ & $\begin{array}{c}4.9 \\
\pm 1.4\end{array}$ & $\begin{array}{l}31.7 \\
\pm 1.6\end{array}$ & $\begin{array}{l}2.2 \\
\pm 0\end{array}$ & $\begin{array}{c}2.0 \\
\pm 0.6\end{array}$ & $\begin{array}{l}66.2 \\
\pm 7.1\end{array}$ & $\begin{array}{l}9.5 \\
\pm 0\end{array}$ & 0.9 & 0.1 & 2.1 \\
\hline 29 & $\begin{array}{l}19.5^{1} \\
\pm 7.5\end{array}$ & $\begin{array}{l}29.9 \\
\pm 2.4\end{array}$ & $\begin{array}{l}31.9 \\
\pm 0.7\end{array}$ & $\begin{array}{l}25.7 \\
\pm 0.8\end{array}$ & $\begin{array}{l}152.0 \\
\pm 0.2\end{array}$ & $\begin{array}{c}217.3 \\
\pm 4.2\end{array}$ & $\begin{array}{l}9.7 \\
\pm 0\end{array}$ & 60 & 5.6 & 6.8 \\
\hline
\end{tabular}

${ }^{1}$ Questionable data (standard deviation $>\left(\right.$ value) ${ }^{1 / 2}$ ) ${ }^{2} \mathrm{~N} . \mathrm{D}$. No data ${ }^{3} \mathrm{SRN}=\mathrm{NO}_{3}+\mathrm{NO}_{2}+\mathrm{NH}_{4}$

Figure 35. Profiles of Temperature, Oxygen, and Light Attenuation in Castle Lake, Station 1 (9-17-93).
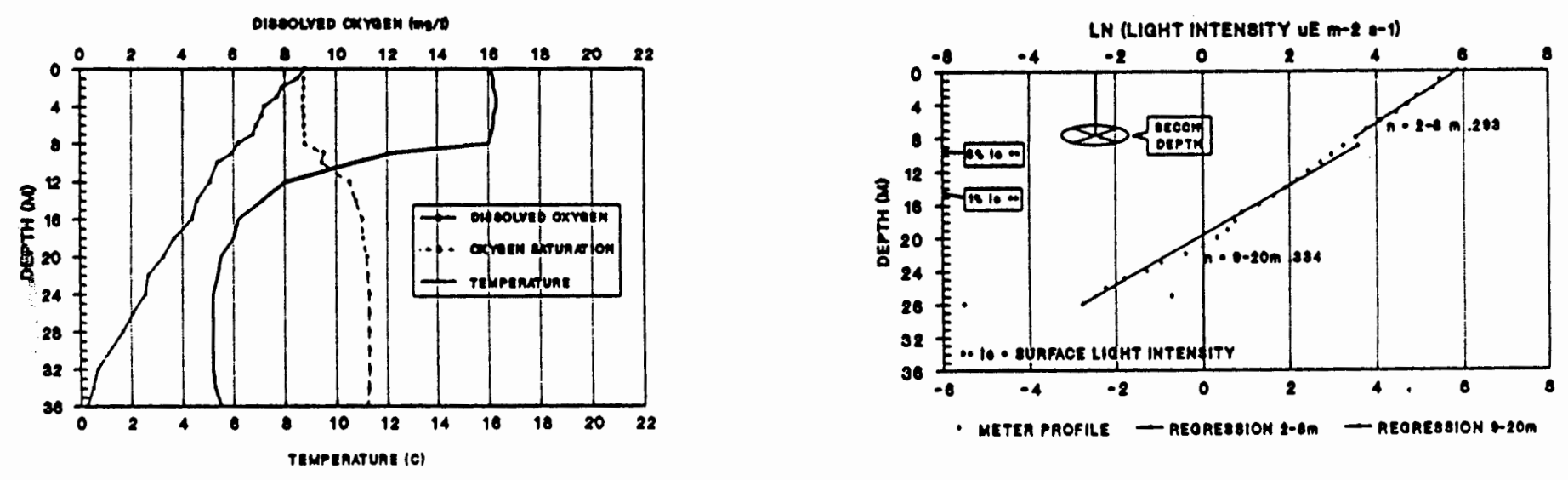
Table 20. Nutrient Concentrations and Ratios and Chlorophyll a Concentrations in Castle Lake, Station 2 (9-17-93).

Values \pm 1 standard deviation.

\begin{tabular}{|c|c|c|c|c|c|c|c|c|c|c|}
\hline $\begin{array}{l}\text { Depth } \\
\text { (m) }\end{array}$ & $\begin{array}{l}\text { Chl. a } \\
(\mu g /)\end{array}$ & $\begin{array}{c}\text { SRP } \\
(\mu g /)\end{array}$ & $\underset{(\mu g / 1)}{\operatorname{TP}}$ & $\begin{array}{c}\mathrm{NO}_{3}+\mathrm{NO}_{2} \\
(\mu g / l)\end{array}$ & $\begin{array}{l}\mathrm{NH}_{4} \\
(\mu \mathrm{g} /)\end{array}$ & $\underset{(\mu g / 1)}{\mathrm{TN}}$ & $\begin{array}{l}\mathrm{SiO}_{2} \\
(\mathrm{mg} / \mathrm{l})\end{array}$ & $\mathrm{SRN}^{3}: \mathrm{SRP}$ & $\mathrm{SRN}^{3}: \mathrm{TP}$ & TN:TP \\
\hline 1 & 23.8 & $\begin{array}{r}6.6^{1} \\
\pm 2.9\end{array}$ & $\begin{array}{l}26.6 \\
\pm 3.8\end{array}$ & $\begin{array}{l}13.8 \\
\pm 0.2\end{array}$ & $\begin{array}{c}3.6 \\
\pm 0.7\end{array}$ & $\begin{array}{l}51.7 \\
\pm 7.9\end{array}$ & $\begin{array}{l}9.5 \\
\pm 0.1\end{array}$ & $3.2^{1}$ & 0.7 & 1.9 \\
\hline 10 & 6.5 & $\begin{array}{c}5.1 \\
\pm 0.6\end{array}$ & 14.5 & $\begin{array}{l}39.0 \\
\pm 0.7\end{array}$ & $\begin{array}{c}3.0 \\
\pm 1.3\end{array}$ & $\begin{array}{l}71.8 \\
\pm 7.9\end{array}$ & $\begin{array}{l}9.4 \\
\pm 0\end{array}$ & 8.3 & 22 & 40.9 \\
\hline 25 & 12.9 & $\begin{array}{c}3.0 \\
\pm 0.1\end{array}$ & $\begin{array}{c}5.2 \\
\pm 2.0\end{array}$ & $\begin{array}{l}53.0 \\
\pm 0.8\end{array}$ & $\begin{array}{l}95.1 \\
\pm 0.1\end{array}$ & $\begin{array}{l}145.6^{1} \\
\pm 20.0\end{array}$ & $\begin{array}{c}9.5 \\
\pm 0.1\end{array}$ & 49.5 & 33.4 & $34.7^{i}$ \\
\hline
\end{tabular}

${ }^{1}$ Questionable data (standard deviation $>(\text { value })^{1 / 2}$ ) ${ }^{2} \mathrm{~N} . \mathrm{D}$. No data ${ }^{3} \mathrm{SRN}=\mathrm{NO}_{3}+\mathrm{NO}_{2}+\mathrm{NH}_{4}$

Figure 36. Profiles of Temperature and Oxygen in Castle Lake, Station 2 and Light Attenuation in Castle Lake, Station 1 (9-17-93).
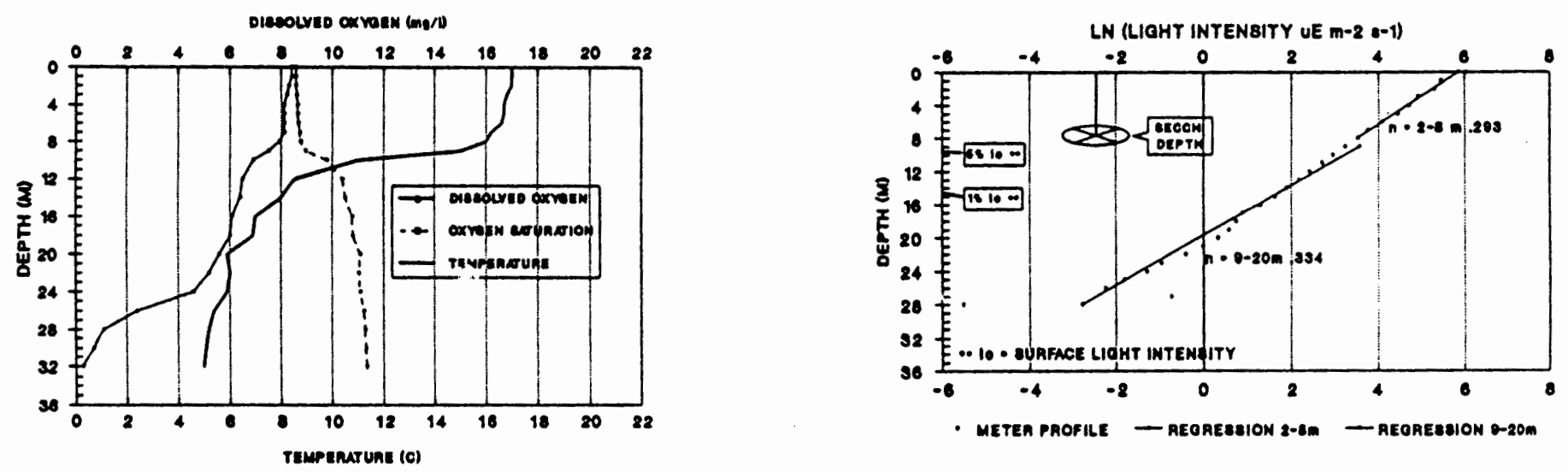


\section{Coldwater Lake}

The May 18, 1980 eruption of Mount St. Helens melted snow and ice on the mountain, creating mud flows (lahars) which flowed down the South Fork of the Toutle River. Debris avalanche deposits dammed the North Coldwater Creek drainage, creating a lake basin. Consequently, the valley behind the debris dam began filling up, creating two lakes, North Coldwater Lake and South Coldwater Lake. As the valley continued to fill, these lakes joined, creating Coldwater Lake. This newly formed lake is bounded by Coldwater Ridge to the north and Johnson Ridge to the south, at an elevation of $740 \mathrm{~m}$, $11 \mathrm{~km}$ from the mountain's crater. Before the 1980 eruption, the Coldwater Creek watershed contained Douglas fir, Western hemlock, and Western redcedar trees. The blast pyrolyzed the forest, depositing large amounts of DOC into the lake watersheds. Coldwater Lake and two other lakes heavily influenced by the massive mudflows (Spirit and newly formed Castle Lakes) had the highest total alkalinities $(1520 \mu \mathrm{eq} / \mathrm{l})$ and the lowest pH values ( 6.61) following the blast (Wissmar et al. 1982a). In August 1980, no oxygen was detected at $0.2 \mathrm{~m}$ depth (Baross et al. 1982). Dissolved oxygen concentrations in the deeper waters decreased steadily throughout 1981, although persistent anaerobic conditions were limited to below $15 \mathrm{~m}$. Dominant biological processes in the lake in the two years following the eruption included anaerobic $\mathrm{N}_{2}$ fixation, denitrification, methanogenesis, and sulfate reduction (Ward et al. 1983). The major tributary to the lake is North Coldwater Creek, which flows in from the east. Another tributary, South Coldwater Creek, has made an interesting impact on the 
chemistry of Coldwater Lake. When the outlet of Spirit Lake was dammed by debris flows from the 1980 eruption, the elevation of the lake began to rise to dangerous levels. In 1985, the U.S. Corp of Engineers completed construction of an outlet tunnel which diverted water from Spirit Lake to the North Fork of the Toutle River via South Coldwater Creek and Coldwater Lake. The water flowing from Spirit Lake contained elevated concentrations of cations and therefore increased cation concentrations in Coldwater Lake (Petersen 1993). Cation concentrations have been declining since 1991 when a delta created by the deposition of sediment from South Coldwater Creek caused the creek to bypass Coldwater Lake, flowing directly into the lake's outlet. Today, an elaborate visitor's center on Coldwater Ridge overlooks the lake and the volcano. Rainbow trout have been stocked in the lake and attract numerous anglers.

\section{Temperature, Oxygen, and Light}

Profiles of temperature, oxygen, and light attenuation for Coldwater Lake are presented in Figures 38-43. A bathymetric map for the lake is available from Kelly (1992). Having a maximum depth of $62 \mathrm{~m}$ and a surface area of 766 acres, Coldwater Lake has a large volume $\left(70,000\right.$ acre feet). The lake was isothermal $\left(3^{\circ} \mathrm{C}\right)$ in March 1993 and dissolved oxygen was saturated throughout the water column. Because of the lake's northeast-southwest orientation, the wind on the lake is sometimes strong and the fetch is long. These features produce a deep thermocline in the summer and fall. In October 1993 and 1994, the lake had a well defined, deep thermocline which extended from 5 to $25 \mathrm{~m}$ and temperatures in the hypolimnion were near $4^{\circ} \mathrm{C}$. Temperature stratification effectively 
effectively separates the hypolimnion from the oxygenated surface waters in the lake. This caused oxygen in the hypolimnion to decrease steadily (clinograde oxygen curve) down to $4.2 \mathrm{mg} / \mathrm{l}$ at $58 \mathrm{~m}(36.6 \%$ saturation). These concentrations of oxygen in bottom waters suggest reducing conditions in the bottom sediments.

In August 1993, the oxygen profile was complex. Oxygen concentrations were elevated (114\% saturation) at $5 \mathrm{~m}$ depth. This suggests a population of phytoplankton at this depth. A slight negative heterograde curve developed in the thermocline at $10 \mathrm{~m}$, and oxygen concentrations decreased to $9 \mathrm{mg} / 1$ ( $90 \%$ saturation). The cooler, denser water in the hypolimnion may slow the flux of decaying cells to the bottom. Decomposition of organic material at the top of the hypolimnion may produce a local drop in oxygen concentrations. Previous oxygen profiles from Coldwater Lake indicate a substantial areal oxygen deficit (460 $\mathrm{mg} \mathrm{O}_{2} \mathrm{~m}^{-1}$ day $^{-1}$ ) (Kelly 1992). Data from 1993 indicate that the high oxygen demand present in 1982 continues to deplete oxygen from bottom waters. Profiles made at two stations in the lake produced similar patterns of temperature and oxygen distribution.

Water transparency in Coldwater Lake is high. During 1993, the average extinction coefficient was $0.27 \mathrm{~m}^{-1}$ (range $0.1-0.4 \mathrm{~m}^{-1}$ ) and the Secchi disk depths ranged from $5.7 \mathrm{~m}$ to $8 \mathrm{~m}$. Profiles of light intensity reveal a complex pattern of light attenuation in the lake. In October 1993, the extinction coefficient was $0.40 \mathrm{~m}^{-1}$ above and $0.19 \mathrm{~m}^{-1}$ below $11 \mathrm{~m}$. A population of phytoplankton near the surface is probably responsible for the elevated light attenuation. Light attenuation increased further in the hypolimnion. Below $37 \mathrm{~m}$ the extinction coefficient increased from $0.19 \mathrm{~m}^{-1}$ te $0.34 \mathrm{~m}^{-1}$. Some chemical 
or biological entity is attenuating the light in the lower half of the lake. A change in extinction coefficient in the deeper portion of the lake has been documented on previous samplings, but has not yet been identified. The depth of $1 \%$ light intensity varied between 10 and $46 \mathrm{~m}$ during this study. Light attenuation data for the lake indicate oligotrophic conditions, although oxygen profiles suggests a more productive classification.

\section{Nutrient Dynamics}

Concentrations of total and dissolved nutrients, chlorophyll-a and nutrient ratios for Coldwater Lake are presented in Tables 21-26. During three samplings in 1993, the SRP concentrations were low, averaging $4.2 \mu \mathrm{g} / \mathrm{l}($ range 1.0 - $6.8 \mu \mathrm{g} / \mathrm{l})$. Nitrate + nitrite concentrations were high, averaging $46.1 \mu \mathrm{g} / \mathrm{l}$ (range 1.8 - $81.4 \mu \mathrm{g} / \mathrm{l}$ ) and ammonium concentrations averaged $9.7 \mu \mathrm{g} / \mathrm{l}$ (range 1.4 - $35.6 \mu \mathrm{g} / \mathrm{l})$.

Limited SRP availability in August 1993 suggest that the growth of the phytoplankton is P limited. In March 1993, SRP concentrations were 2.9 and $5.1 \mu \mathrm{g} / \mathrm{l}$ at 1 and $23 \mathrm{~m}$, respectively. By August 1993, the SRP concentration had decreased to 1.0 and $1.5 \mu \mathrm{g} / \mathrm{l}$ at 1 and $9 \mathrm{~m}$, respectively. Decreased chlorophyll-a concentrations in August suggests that $\mathbf{P}$ concentrations are limiting to the phytoplankton. Chlorophyll-a concentrations at $1 \mathrm{~m}$ decreased from 53.8 in March to $8.9 \mu \mathrm{g} / \mathrm{l}$ in August, 1993. The extinction coefficient also decreased slightly (from $0.34 \mathrm{~m}^{-1}$ to $0.32 \mathrm{~m}^{-1}$ ) and the Secchi disk depth increased from 5.7 to $7.2 \mathrm{~m}$. The phytoplankton community may have been severely constrained by the limited availability of SRP which could result in decreased pigment production (or biomass). 
Nitrogen concentrations in Coldwater Lake were consistently high and do not imply a deficiency. The lowest DIN concentrations in the surface waters occurred during March $1993(35 \mu \mathrm{g} / 1)$, when SRP concentrations were highest. Because SRP was available, $\mathrm{N}$ could be assimilated into biomass. In August 1993, however, the DIN increased to near $50 \mu \mathrm{g} /$, when SRP concentrations were low. The possibly limiting concentrations of SRP at this time prevented the assimilation of $\mathrm{N}$. The increase in the concentration of DIN was primarily due to increases in nitrate + nitrite concentrations. Bacterial nitrification is one mechanism which could produce increases in nitrate concentrations. Nitrifying bacteria oxidize reduced $\mathrm{N}$ compounds to nitrite and nitrate, extracting energy in the process (Wetzel 1983).

Concentrations of $\mathrm{N}$ were related to the patterns of oxygen availability in the lake. During periods of oxygen depletion in the hypolimnion, ammonium concentrations were elevated, while nitrate + nitrite concentrations declined. As the growing season progressed from August to October 1993, the concentrations of ammonium in the hypolimnion increased from 14.6 to $35.6 \mu \mathrm{g} /$ and nitrate + nitrite concentrations decreased slightly from 79.9 to $75.5 \mu \mathrm{g} /$. Anoxic conditions in the hypolimnion would favor reduced nitrogen (ammonium) over nitrate, (oxidized nitrogen). The abundance of DIN in the lake suggests sufficient concentrations for the plankton.

Concentrations of Si remained high throughout the year, and were always above $8.8 \mathrm{mg} / \mathrm{l}$. In 1993, the dominant phytoplankton species in Coldwater Lake were the smalf diatom Cyclotella comta, the Chrysophyte Kephyrion, and the green algae Planktosphaeria gelatinosa (Baker 1995). In August 1993, concentrations of Si were 
lowest in the epilimnion and metalimnion $(8.8 \mathrm{mg} / \mathrm{l})$, and increased to $9.3 \mathrm{mg} / \mathrm{l}$ at $45 \mathrm{~m}$. This may reflect the dissolution of Si from the bottom sediments or assimilation of Si and subsequent sedimentation of diatom frustrules to the bottom. Because $\mathrm{Si}$ is so plentiful in Coldwater Lake, it is doubtful that this nutrient would limit the growth of the diatomaceous phytoplankton.

\section{Nutrient Ratios}

DIN:SRP ratios for Coldwater Lake during 1993 differ with respect to both sampling date and depth. In March 1993, the DIN:SRP ratios varied from 14.6 at $1 \mathrm{~m}$ to 4.1 in the hypolimnion. These values do not indicate substantial nutrient limitation, although SRP concentrations were low $(5 \mu \mathrm{g} / 1)$. Nutrient ratios in August 1993, however, clearly indicate $\mathrm{P}$ limitation. DIN:SRP ratios in the epilimnion and metalimnion were always above 40 , and reached a maximum 51.8 at $1 \mathrm{~m}$.

In October 1993, however, a decline in the concentrations of DIN coupled with increased SRP availability produced lower DIN:SRP ratios in the epilimnion (1.9 - 2.7), suggesting $\mathrm{N}$ limitation. At this time, the TN:TP ratio in the epilimnion averaged 3.5, and ratios in the metalimnion and hypolimnion were near the Redfield value of 7.2 . These data may be misleading, considering concentrations of both DIN $(16 \mu \mathrm{g} / \mathrm{l})$ and SRP $(6 \mu \mathrm{g} / \mathrm{l})$ may have been sufficient to support unlimited plankton growth. 
Bioassays

Alkaline Phosphatase

Data on alkaline

phosphatase enzyme activity

(APA) during October 1993

suggest that the plankton

community in Coldwater

Lake is $\mathbf{P}$ deficient (Figure

37). Plankton collected from

$4 \mathrm{~m}$ depth produced a $31 \%$

average (SD 1.9) increase in

Alkaline Phosphatase Activity

Coldwater Lake October 1993

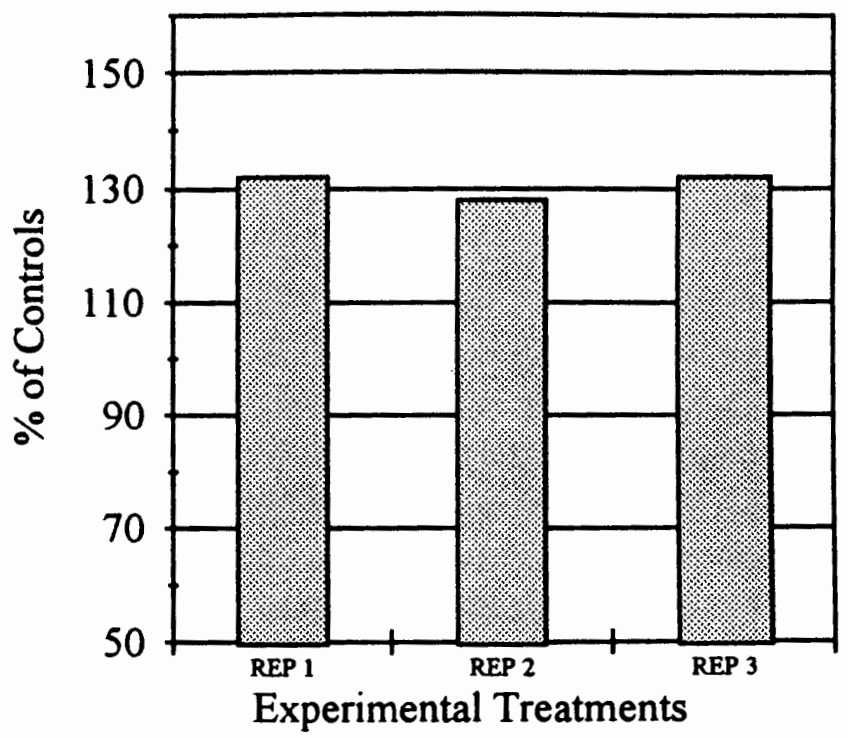

Figure 37

APA compared to blank

controls. APA confirms that $\mathrm{P}$ is in short supply in Coldwater Lake.

\section{Conclusion}

The limited availability of $P$ in Coldwater Lake and high $N: P$ ratios suggest the plankton are $\mathrm{P}$ limited during periods of stratification. Uptake of SRP from surface waters exceeded that for DIN, provides evidence that $\mathrm{P}$ will be depleted prior to $\mathrm{N}$. The reduced chlorophyll-a concentrations in August occurred at a time when SRP concentrations were at a minimum. Elevated APA in October 1993 confirms the shortage of $\mathrm{P}$ in Coldwater Lake. 
Table 21. Nutrient Concentrations and Ratios and Chlorophyll a Concentrations in Coldwater Lake, Station 1 (3-24-93). Values \pm 1 standard deviation.

\begin{tabular}{|c|c|c|c|c|c|c|c|c|c|c|}
\hline $\begin{array}{l}\text { Depth } \\
\text { (m) }\end{array}$ & $\begin{array}{l}\text { Chl. a } \\
(\mu g / l)\end{array}$ & $\begin{array}{c}\text { SRP } \\
(\mu g / 1)\end{array}$ & $\underset{(\mu g / 1)}{\operatorname{TP}}$ & $\begin{array}{c}\mathrm{NO}_{3}+\mathrm{NO}_{2} \\
(\mu \mathrm{g} /)\end{array}$ & $\begin{array}{l}\mathrm{NH}_{4} \\
(\mu \mathrm{g} /)\end{array}$ & $\begin{array}{c}\text { TN } \\
(\mu g / 1)\end{array}$ & $\begin{array}{l}\mathrm{SiO}_{2} \\
(\mathrm{mg} /)\end{array}$ & $\mathrm{SRN}^{3}: \mathrm{SRP}$ & $S R N^{3}: T P$ & TN:TP \\
\hline 1 & 53.8 & $\begin{array}{c}2.9 \\
\pm 0.7\end{array}$ & N.D. ${ }^{2}$ & $\begin{array}{r}37.5^{1} \\
+6.3\end{array}$ & $\begin{array}{l}3.1 \\
\pm 0\end{array}$ & N.D. ${ }^{2}$ & $\begin{array}{c}9.4 \\
\pm 0.1\end{array}$ & $14.6^{1}$ & N.D. ${ }^{2}$ & N.D. ${ }^{2}$ \\
\hline 23 & 40.2 & $\begin{array}{c}5.1 \\
\pm 1.5\end{array}$ & N.D. ${ }^{2}$ & $\begin{array}{l}32.5 \\
\pm 1.7\end{array}$ & $\begin{array}{c}1.4 \\
\pm 0.6\end{array}$ & N.D. ${ }^{2}$ & $\begin{array}{c}9.4 \\
\pm 0.1\end{array}$ & 7.2 & N.D. ${ }^{2}$ & N.D. ${ }^{2}$ \\
\hline 56.5 & 5.8 & $\begin{array}{l}5.1 \\
\pm 0\end{array}$ & N.D. ${ }^{2}$ & $\begin{array}{l}19.5 \\
\pm 3.4\end{array}$ & $\begin{array}{c}1.4 \\
\pm 0.6\end{array}$ & N.D. ${ }^{2}$ & $\begin{array}{l}9.4 \\
\pm 0\end{array}$ & 4.1 & N.D. ${ }^{2}$ & N.D. ${ }^{2}$ \\
\hline
\end{tabular}

${ }^{1}$ Questionable data (standard deviation $>(\text { value })^{1 / 2}$ ) ${ }^{2}$ N.D. No data ${ }^{3} \mathrm{SRN}=\mathrm{NO}_{3}+\mathrm{NO}_{2}+\mathrm{NH}_{4}$

Figure 38. Profiles of Temperature, Oxygen, and Light Attenuation in Coldwater Lake, Station 1 (3-24-93).
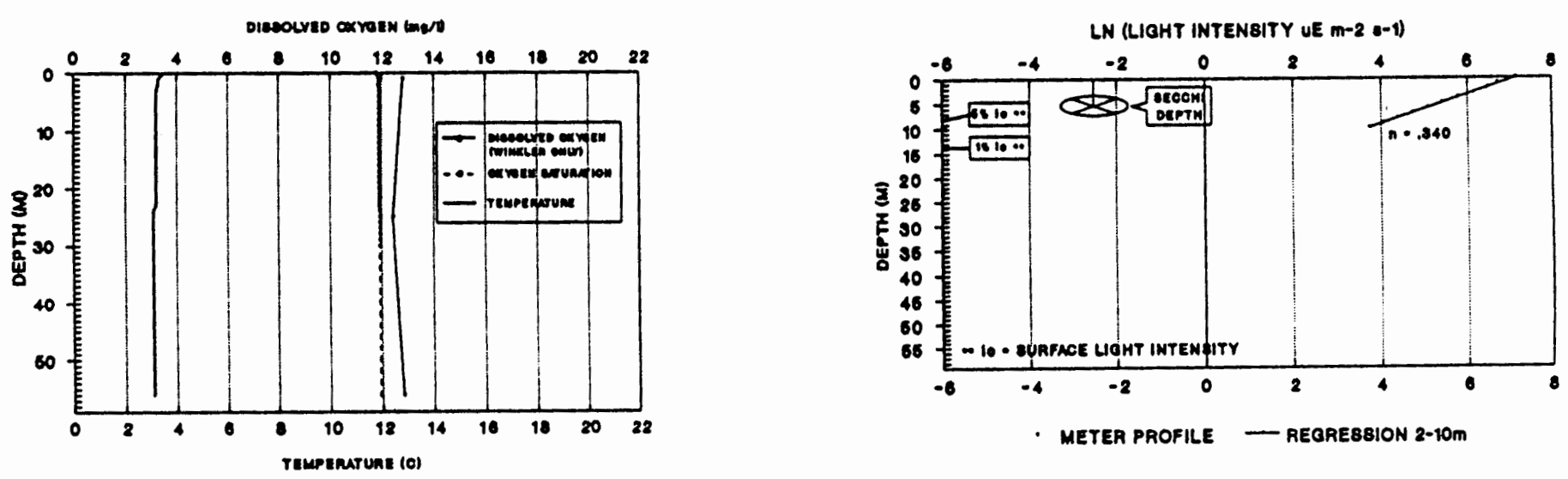
Table 22. Nutrient Concentrations and Ratios and Chlorophyll a Concentrations in Coldwater Lake, Station 2 (3-24-93). Values \pm 1 standard deviation.

\begin{tabular}{|c|c|c|c|c|c|c|c|c|c|c|}
\hline $\begin{array}{l}\text { Depth } \\
\text { (m) }\end{array}$ & $\begin{array}{l}\text { Chl. \& } \\
(\mu \mathrm{g} /)\end{array}$ & $\begin{array}{c}\text { SRP } \\
(\mu \mathrm{g} / 1)\end{array}$ & $\underset{(\mu \mathrm{g} / 1)}{\mathrm{TP}}$ & $\underset{(\mu g /)}{\mathrm{NO}_{3}+\mathrm{NO}_{2}}$ & $\begin{array}{l}\mathrm{NH}_{4} \\
(\mu \mathrm{g} /)\end{array}$ & $\underset{(\mu \mathrm{g} /)}{\mathrm{TN}}$ & $\begin{array}{l}\mathrm{SiO}_{2} \\
(\mathrm{~m} / \mathrm{l})\end{array}$ & $S R N^{3}: S R P$ & $\mathrm{SRN}^{3}: \mathrm{TP}$ & TN:TP \\
\hline 1 & 53.1 & $\begin{array}{l}5.1 \\
\pm 0\end{array}$ & N.D. ${ }^{2}$ & $\begin{array}{l}24.1 \\
\pm 2.1\end{array}$ & $\begin{array}{l}1.9 \\
\pm 0\end{array}$ & N.D. ${ }^{2}$ & $\begin{array}{l}9.4 \\
\pm 0\end{array}$ & 5.1 & N.D. ${ }^{2}$ & N.D. ${ }^{2}$ \\
\hline 23 & 39.3 & $\begin{array}{l}5.1 \\
\pm 0\end{array}$ & N.D. ${ }^{2}$ & $\begin{array}{r}21.6^{1} \\
\pm 7.5\end{array}$ & $\begin{array}{l}1.9 \\
\pm 0\end{array}$ & N.D. ${ }^{2}$ & $\begin{array}{l}9.4 \\
\pm 0\end{array}$ & $4.6^{1}$ & N.D. ${ }^{2}$ & N.D. ${ }^{2}$ \\
\hline 40 & 29.8 & $\begin{array}{l}5.1 \\
\pm 0\end{array}$ & N.D. ${ }^{2}$ & $\begin{array}{l}28.7 \\
\pm 1.7\end{array}$ & $\begin{array}{l}3.1 \\
\pm 0\end{array}$ & N.D. ${ }^{2}$ & $\begin{array}{l}9.4 \\
\pm 0\end{array}$ & 6.2 & N.D. ${ }^{2}$ & N.D. ${ }^{2}$ \\
\hline
\end{tabular}

${ }^{1}$ Questionable data (standard deviation $>(\text { value })^{1 / 2}$ ) ${ }^{2} \mathrm{~N} . \mathrm{D}$. No data ${ }^{3} \mathrm{SRN}=\mathrm{NO}_{3}+\mathrm{NO}_{2}+\mathrm{NH}_{4}$

Figure 39. Profiles of Temperature and Oxygen in Coldwater Lake, Station 2 and Light Attenuation in Coldwater Lake, Station 1 (324-93).
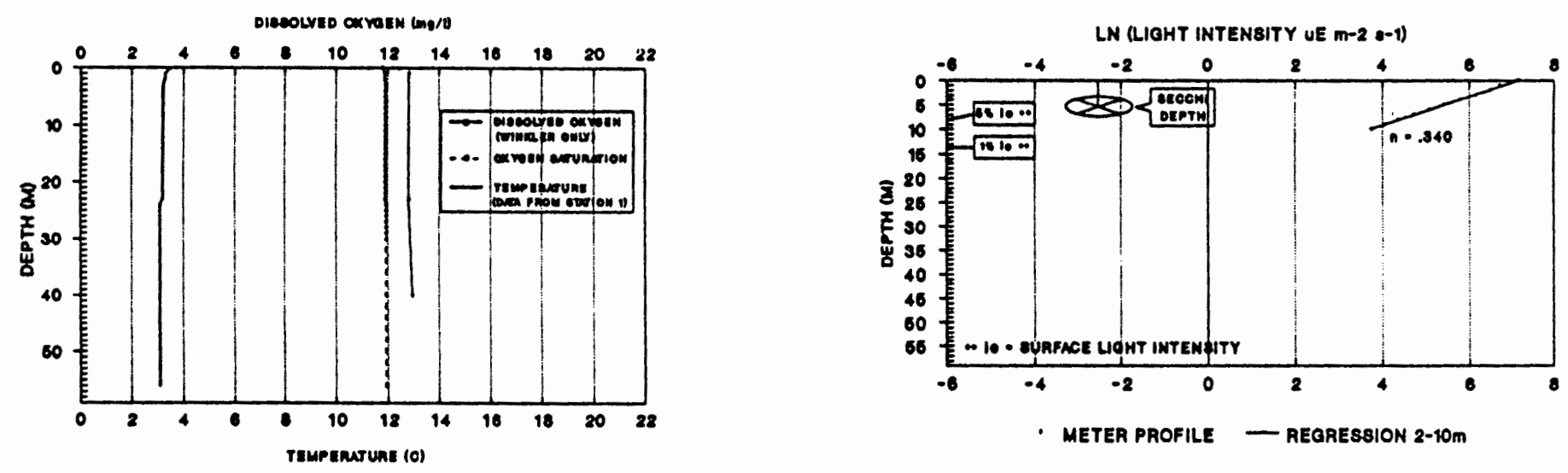
Table 23. Nutrient Concentrations and Ratios and Chlorophyll a Concentrations in Coldwater Lake, Station 1 (8-9-93). Values \pm 1 standard deviation.

\begin{tabular}{|c|c|c|c|c|c|c|c|c|c|c|}
\hline $\begin{array}{l}\text { Depth } \\
\text { (m) }\end{array}$ & $\begin{array}{l}\text { Chl. a } \\
(\mu \mathrm{g} / \mathrm{I})\end{array}$ & $\begin{array}{c}\text { SRP } \\
(\mu g / I)\end{array}$ & $\underset{(\mu g /)}{\operatorname{TP}}$ & $\underset{(\mu g n)}{\mathrm{NO}_{3}+\mathrm{NO}_{2}}$ & $\begin{array}{l}\mathrm{NH}_{4} \\
(\mu \mathrm{g} /)\end{array}$ & $\underset{(\mu g /)}{\mathrm{TN}}$ & $\begin{array}{l}\mathrm{SiO}_{2} \\
(\mathrm{mg} /)\end{array}$ & SRN $N^{3}: S R P$ & $\mathrm{SRN}^{3}: \mathrm{TP}$ & TN:TP \\
\hline 1 & 8.9 & $\begin{array}{c}1.0 \\
\pm 0.2\end{array}$ & N.D. ${ }^{2}$ & $\begin{array}{l}46.9 \\
\pm 1.1\end{array}$ & $\begin{array}{c}3.8 \\
\pm 0.8\end{array}$ & N.D. ${ }^{2}$ & $\begin{array}{c}8.8 \\
\pm 0.2\end{array}$ & 51.8 & N.D. ${ }^{2}$ & N.D. ${ }^{2}$ \\
\hline 9 & 14.4 & $\begin{array}{c}1.5 \\
\pm 0.6\end{array}$ & N.D. ${ }^{2}$ & $\begin{array}{l}47.3 \\
\pm 0.2\end{array}$ & $\begin{array}{c}6.2 \\
\pm 0.3\end{array}$ & N.D. ${ }^{2}$ & $\begin{array}{c}8.8 \\
\pm 0.1\end{array}$ & 44.5 & N.D. ${ }^{2}$ & N.D. ${ }^{2}$ \\
\hline 45 & 9.4 & $\begin{array}{c}1.3 \\
\pm 0.5\end{array}$ & N.D. ${ }^{2}$ & $\begin{array}{l}79.9 \\
\pm 0.4\end{array}$ & $\begin{array}{l}14.6 \\
\pm 0.4\end{array}$ & N.D. ${ }^{2}$ & $\begin{array}{l}9.3 \\
\pm 0\end{array}$ & 82.8 & N.D. ${ }^{2}$ & N.D. ${ }^{2}$ \\
\hline
\end{tabular}

${ }^{2}$ N.D. No data ${ }^{3} \mathrm{SRN}=\mathrm{NO}_{3}+\mathrm{NO}_{2}+\mathrm{NH}_{4}$

Figure 40. Profiles of Temperature, Oxygen, and Light Attenuation in Coldwater Lake, Station 1 (8-9-93).
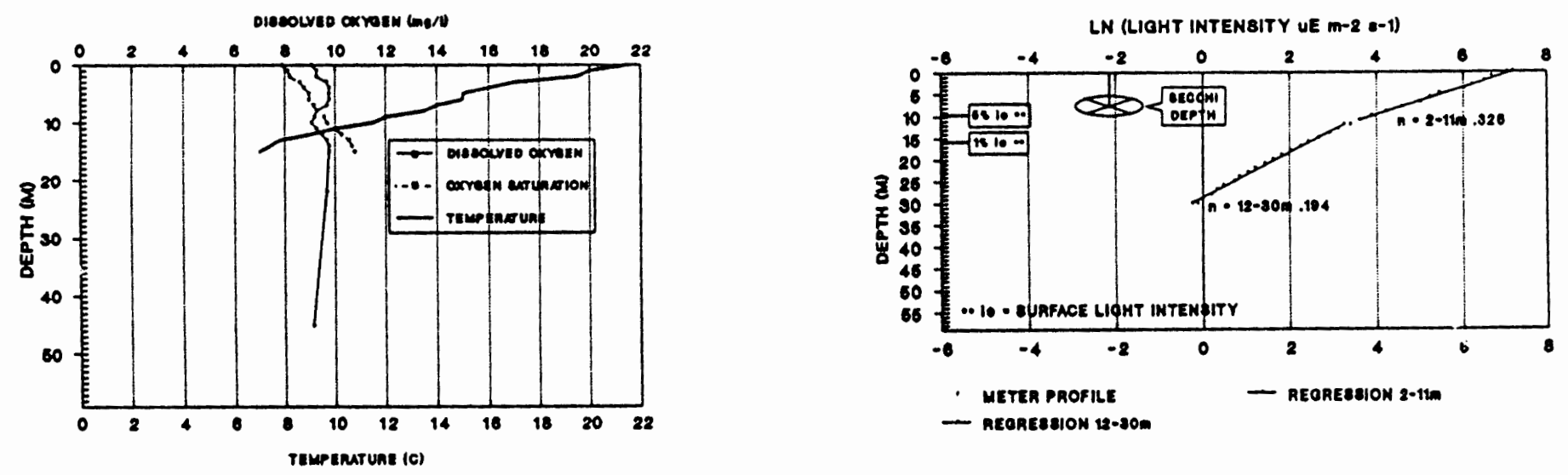
Table 24. Nutrient Concentrations and Ratios and Chlorophyll a Concentrations in Coldwater Lake, Station 2 (8-9-93). Values \pm 1 standard deviation.

\begin{tabular}{|c|c|c|c|c|c|c|c|c|c|c|}
\hline $\begin{array}{l}\text { Depth } \\
\text { (m) }\end{array}$ & $\begin{array}{l}\text { Chl. a } \\
(\mu g /)\end{array}$ & $\begin{array}{c}\text { SRP } \\
(\mu g /)\end{array}$ & $\begin{array}{c}\text { TP } \\
(\mu g /)\end{array}$ & $\begin{array}{c}\mathrm{NO}_{3}+\mathrm{NO}_{2} \\
(\mu \mathrm{g} / \mathrm{l})\end{array}$ & $\begin{array}{l}\mathrm{NH}_{4} \\
(\mu g / 1)\end{array}$ & $\begin{array}{c}T N \\
(\mu g / 1)\end{array}$ & $\begin{array}{l}\mathrm{SiO}_{2} \\
(\mathrm{mg} / 1)\end{array}$ & SRN ${ }^{3}: S R P$ & $S R N^{3}: T P$ & TN:TP \\
\hline 1 & 60.4 & $\begin{array}{c}1.5 \\
\pm 0.3\end{array}$ & N.D. ${ }^{2}$ & $\begin{array}{l}64.8^{1} \\
\pm 19.8\end{array}$ & $\begin{array}{c}2.4 \\
\pm 1.1\end{array}$ & N.D. ${ }^{2}$ & $\begin{array}{c}9.0 \\
\pm 0.1\end{array}$ & $45.5^{1}$ & N.D. ${ }^{2}$ & N.D. ${ }^{2}$ \\
\hline 7 & 16.5 & $\begin{array}{c}1.3 \\
\pm 0.2\end{array}$ & N.D. ${ }^{2}$ & $\begin{array}{l}48.5 \\
\pm 6.1\end{array}$ & $\begin{array}{c}4.0 \\
\pm 1.1\end{array}$ & N.D. ${ }^{2}$ & $\begin{array}{c}9.1 \\
\pm 0.2\end{array}$ & 40.2 & N.D. ${ }^{2}$ & N.D. ${ }^{2}$ \\
\hline 35 & 2.0 & $\begin{array}{l}1.5 \\
\pm 0\end{array}$ & N.D. ${ }^{2}$ & $\begin{array}{l}81.4 \\
\pm 2.5\end{array}$ & $\begin{array}{l}11.5 \\
\pm 0.8\end{array}$ & N.D. ${ }^{2}$ & $\begin{array}{l}10.4 \\
\pm 0.2\end{array}$ & 63.8 & N.D. ${ }^{2}$ & N.D. ${ }^{2}$ \\
\hline
\end{tabular}

${ }^{1}$ Questionable data (standard deviation $>(\text { value })^{1 / 2}$ ) ${ }^{2} \mathrm{~N} . \mathrm{D}$. No data ${ }^{3} \mathrm{SRN}=\mathrm{NO}_{3}+\mathrm{NO}_{2}+\mathrm{NH}_{4}$

Figure 41. Profiles of Temperature and Oxygen in Coldwater Lake, Station 2 and Light Attenuation in Coldwater Lake, Station 1 (89-93).
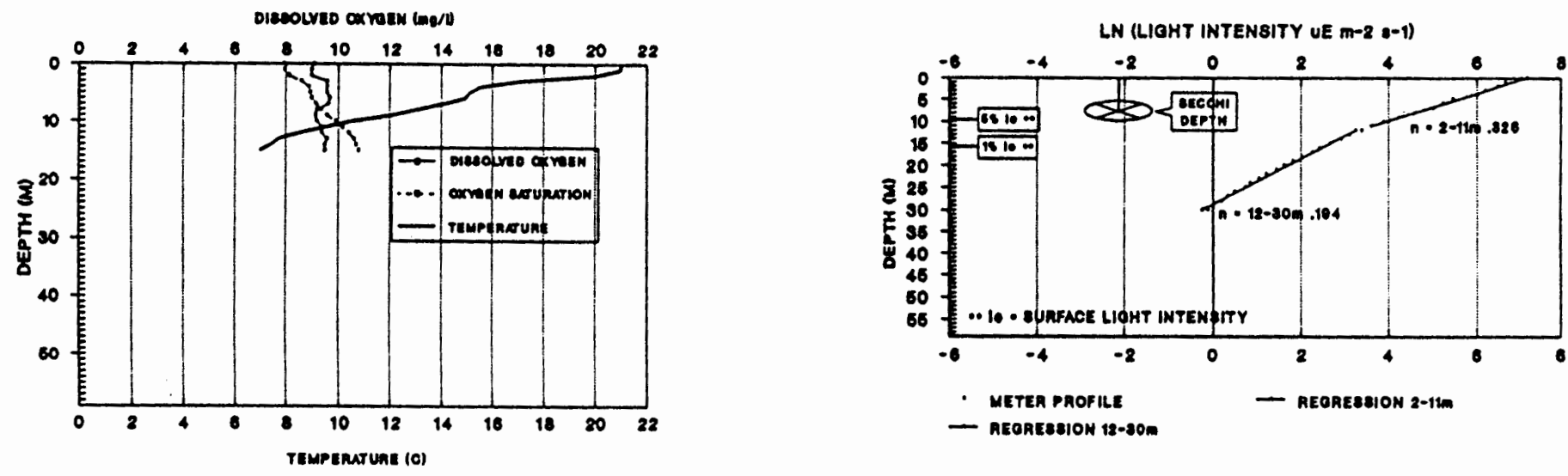
Table 25. Nutrient Concentrations and Ratios and Chlorophyll a Concentrations in Coldwater Lake, Station 1 (10-2-93). Values \pm 1 standard deviation.

\begin{tabular}{|c|c|c|c|c|c|c|c|c|c|c|}
\hline $\begin{array}{l}\text { Depth } \\
\text { (m) }\end{array}$ & $\begin{array}{l}\text { Chl. a } \\
(\mu g / 1)\end{array}$ & $\begin{array}{c}\text { SRP } \\
(\mu g / 1)\end{array}$ & $\underset{(\mu g /)}{\operatorname{TP}}$ & $\begin{array}{c}\mathrm{NO}_{3}+\mathrm{NO}_{2} \\
(\mu \mathrm{g} /)\end{array}$ & $\begin{array}{l}\mathrm{NH}_{4} \\
(\mu \mathrm{g} /)\end{array}$ & $\begin{array}{c}\text { TN } \\
(\mu \mathrm{g} /)\end{array}$ & $\begin{array}{l}\mathrm{SiO}_{2} \\
(\mathrm{mg} / \mathrm{l})\end{array}$ & $S R N^{3}: S R P$ & $S R N^{3}: T P$ & TN:TP \\
\hline 1 & $\begin{array}{l}22.8^{1} \\
\pm 15.7\end{array}$ & $\begin{array}{c}6.4 \\
\pm 0.2\end{array}$ & $\begin{array}{l}22.1 \\
\pm 0.2\end{array}$ & $\begin{array}{c}1.8 \\
\pm 0.2\end{array}$ & $\begin{array}{l}14.9^{1} \\
\pm 8.4\end{array}$ & $\begin{array}{l}67.9^{1} \\
\pm 10.9\end{array}$ & $\begin{array}{l}10.8 \\
\pm 0\end{array}$ & $2.7^{1}$ & $0.8^{1}$ & $3.1^{1}$ \\
\hline 20 & $\begin{array}{l}11.5 \\
\pm 2.9\end{array}$ & $\begin{array}{l}6.2 \\
\pm 0\end{array}$ & $\begin{array}{l}20.5 \\
\pm 0.2\end{array}$ & $\begin{array}{l}69.4 \\
\pm 0.3\end{array}$ & $\begin{array}{l}18.2 \\
\pm 0.9\end{array}$ & $\begin{array}{l}161.1 \\
\pm 10.5\end{array}$ & $\begin{array}{l}11.1 \\
\pm 0\end{array}$ & 14.1 & 4.3 & 7.9 \\
\hline 55 & $\begin{array}{c}1.4 \\
\pm 0.5\end{array}$ & $\begin{array}{l}6.8 \\
\pm 0\end{array}$ & $\begin{array}{l}24.5 \\
\pm 3.4\end{array}$ & $\begin{array}{l}75.5 \\
\pm 0.8\end{array}$ & $\begin{array}{l}35.6 \\
\pm 1.7\end{array}$ & $\begin{array}{l}173.6 \\
\pm 12.1\end{array}$ & $\begin{array}{l}11.3 \\
\pm 0\end{array}$ & 16.3 & 4.6 & 7.3 \\
\hline
\end{tabular}

${ }^{1}$ Questionable data (standard deviation $>(\text { value })^{\mathrm{i} / 2}$ ) ${ }^{2} \mathrm{~N}$.D. No data ${ }^{3} \mathrm{SRN}=\mathrm{NO}_{3}+\mathrm{NO}_{2}+\mathrm{NH}_{4}$

Figure 42. Profiles of Temperature and Oxygen in Coldwater Lake, Station 1 and Light Attenuation in Coldwater Lake, Station 2 (10-2-93).
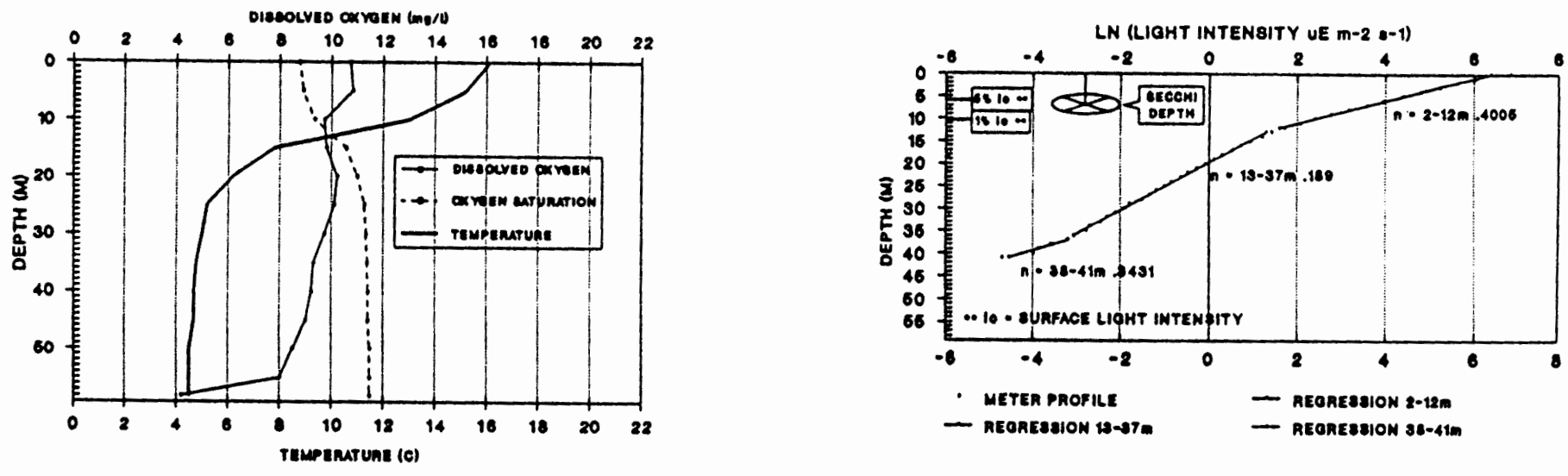
Table 26. Nutrient Concentrations and Ratios and Chlorophyll a Concentrations in Coldwater Lake, Station 2 (10-2-93). Values \pm 1 standard deviation.

\begin{tabular}{|c|c|c|c|c|c|c|c|c|c|c|}
\hline $\begin{array}{l}\text { Depth } \\
\text { (m) }\end{array}$ & $\begin{array}{l}\text { Chl. a } \\
(\mu g /)\end{array}$ & $\begin{array}{l}\text { SRP } \\
(\mu \mathrm{g} /)\end{array}$ & $\underset{(\mu g /)}{\operatorname{TP}}$ & $\begin{array}{c}\mathrm{NO}_{3}+\mathrm{NO}_{2} \\
(\mu \mathrm{g} /)\end{array}$ & $\begin{array}{l}\mathrm{NH}_{4} \\
(\mu \mathrm{g} /)\end{array}$ & $\underset{(\mu g /)}{\mathrm{TN}}$ & $\begin{array}{l}\mathrm{SiO}_{2} \\
(\mathrm{mg} / \mathrm{l})\end{array}$ & SRN':SRP & $S R N^{3}: T P$ & TN:TP \\
\hline 1 & $\begin{array}{l}24.6^{1} \\
\pm 10.0\end{array}$ & $\begin{array}{l}6.2 \\
\pm 0\end{array}$ & $\begin{array}{l}24.9 \\
\pm 1.0\end{array}$ & $\begin{array}{c}6.1 \\
\pm 1.4\end{array}$ & $\begin{array}{c}5.4 \\
\pm 0.6\end{array}$ & $\begin{array}{l}97.1 \\
\pm 0.8\end{array}$ & $\begin{array}{l}10.8 \\
\pm 0.1\end{array}$ & 1.9 & 0.5 & 3.9 \\
\hline 20 & $\begin{array}{l}13.6 \\
\pm 1.8\end{array}$ & $\begin{array}{c}6.5 \\
\pm 0.3\end{array}$ & $\begin{array}{l}28.5 \\
\pm 5.0\end{array}$ & $\begin{array}{l}70.2 \\
\pm 0.2\end{array}$ & $\begin{array}{l}19.4 \\
\pm 0.1\end{array}$ & $\begin{array}{l}174.5^{1} \\
\pm 18.8\end{array}$ & $\begin{array}{l}11.6 \\
\pm 0.5\end{array}$ & 13.8 & 46.3 & $6.4^{1}$ \\
\hline 40 & $\begin{array}{r}6.4^{1} \\
\pm 4.7\end{array}$ & $\begin{array}{l}6.8 \\
\pm 0\end{array}$ & $\begin{array}{l}22.9 \\
\pm 1.0\end{array}$ & $\begin{array}{l}73.8 \\
\pm 0.9\end{array}$ & $\begin{array}{l}25.4 \\
\pm 0.6\end{array}$ & $\begin{array}{l}140.6 \\
\pm 0.8\end{array}$ & $\begin{array}{l}11.5 \\
\pm 0.1\end{array}$ & 14.6 & 4.3 & 6.2 \\
\hline
\end{tabular}

${ }^{1}$ Questionable data (standard deviation $>(\text { value })^{1 / 2}$ ) ${ }^{2} \mathrm{~N} . \mathrm{D}$. No data ${ }^{3} \mathrm{SRN}=\mathrm{NO}_{3}+\mathrm{NO}_{2}+\mathrm{NH}_{4}$

Figure 43. Profiles of Temperature and Oxygen in Coldwater Lake, Station 1 and Light Attenuation in Coldwater Lake, Station 2 (10-2-93).
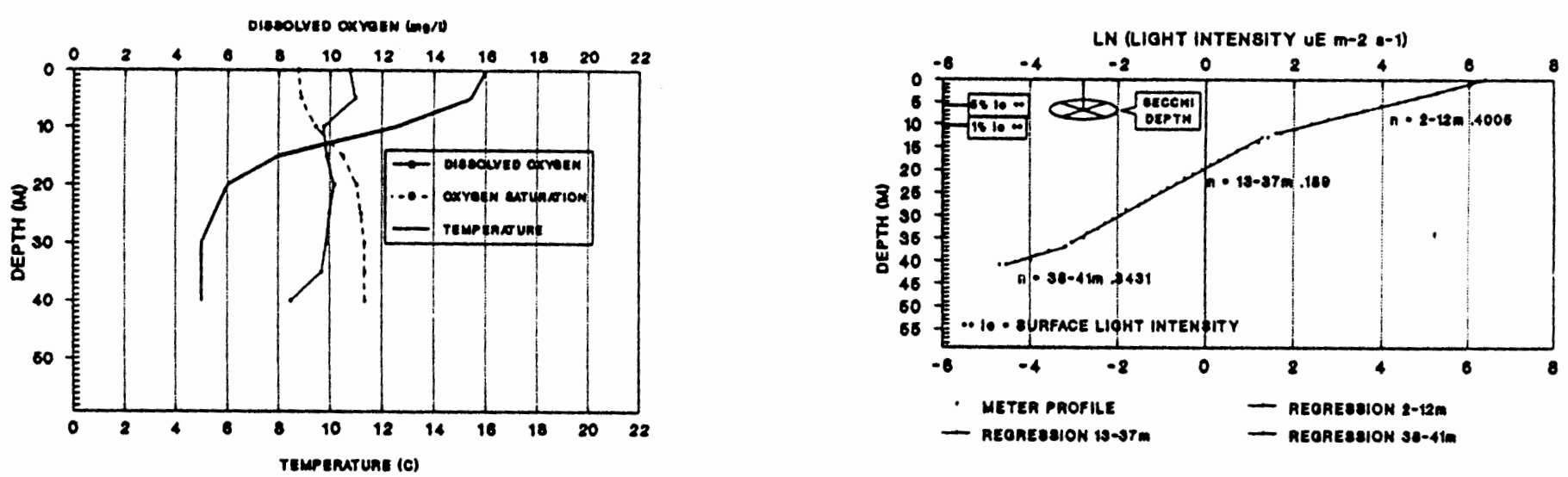


\section{Blue Lake}

Blue Lake lies in a cirque basin (elevation $1200 \mathrm{~m}$ ) in an undisturbed, forested watershed, $28 \mathrm{~km}$ east of Mt. St. Helens. This subalpine lake is deep and clear, having a maximum depth of $30 \mathrm{~m}$. The lake received only ashfall from the 1980 eruption of Mt. St. Helens and subsequently has been used to represent conditions typical of Cascade lakes.

\section{Temperature, Oxygen, and Light}

Profiles of temperature and oxygen and Secchi disk depth for Blue Lake are presented in Figure 44. Blue Lake was distinctly stratified in July 1993, when a distinct thermocline developed at $4 \mathrm{~m}$. This effectively separated the epilimnion from the bottom water. Temperatures were $11^{\circ} \mathrm{C}$ at the surface and $4^{\circ} \mathrm{C}$ throughout the hypolimnion. In July 1993, dissolved oxygen concentrations were nearly saturated at the surface but decreased with depth (clinograde oxygen curve). In the hypolimnion, oxygen decreased to below $1 \mathrm{mg} /(7.2 \%$ saturation). These data suggest that reducing conditions would be present in the bottom sediments.

Water transparency in Blue Lake is high, although profiles of light attenuation were not obtained during this study. The Secchi disk depth in July 1993 was high (12.8 $\mathrm{m})$. The Secchi disk depth has been shown to approximate $10 \%$ surface light intensity (Wetzel 1983). The extinction coefficient for Blue Lake following the eruption was 0.71 $\mathrm{m}^{-1}$ (Wissmar et al. 1982b). The light data indicate oligotrophic conditions in Blue lake, although the oxygen profile suggests a more productive classification. 


\section{Nutrient Dynamics}

Concentrations of total and dissolved nutrients, chlorophyll-a and nutrient ratios for Blue Lake are presented in Table 27. In July 1993, the average SRP concentration was $6.6 \mu \mathrm{g} / \mathrm{l}$ (range $6.0-7.6 \mu \mathrm{g} / \mathrm{l}$ ). The homogeneous distribution of SRP in Blue lake during stratification suggests sufficient concentrations are available to the plankton. The average nitrate + nitrite concentration was $18.7 \mu \mathrm{g} /($ (range $6.5-39.0 \mu \mathrm{g} / \mathrm{l})$ while ammonium concentrations averaged $9.8 \mu \mathrm{g} / \mathrm{l}$ (range $4.3-19.0 \mu \mathrm{g} / \mathrm{l}$ ). The ammonium concentration was lowest in the metalimnion $(4.3 \mu \mathrm{g} /)$ where the chlorophyll-a concentration was the highest $(31.6 \mu \mathrm{g} /)$, suggesting assimilation of ammonium and growth by the phytoplankton community. Populations of phytoplankton located in deeper water often manufacture more chlorophyll-a when less light is available. Higher concentrations $(10.5 \mu \mathrm{g} /)$ of nitrate + nitrite were present at this time, although these forms of nitrogen must first be reduced to ammonium before they can be assimilated into cell constituents, which requires energy. Consequently, ammonium would be the preferred source of nitrogen for phytoplankton (Wetzel 1983).

TP averaged $18.3 \mu \mathrm{g} /($ (range $13.7-22.1 \mu \mathrm{g} /$ ), while concentrations of TN averaged $39 \mu \mathrm{g} /$ in the upper $10 \mathrm{~m}$. These measures of biomass indicate mesotrophic conditions in Blue Lake, which is supported by the oxygen profile.

In August 1993, concentrations of DIN and SRP were elevated in the hypolimnion. The concentration of nitrate + nitrite was $39.1 \mu \mathrm{g} /$ and ammonium was $18.8 \mu \mathrm{g} /$. The concentration of SRP was $7.6 \mu \mathrm{g} /$ at this time. Limited light availability may have prevented autotrophic assimilation of these nutrients at these depths. 
Concentrations of $\mathrm{Si}$ were high, ranging from $5.7-7.5 \mathrm{mg} / \mathrm{l}$. Concentrations increased with increasing depth, suggesting dissolution of $\mathrm{Si}$ from the bottom sediments or assimilation and subsequent sedimentation of silicious phytoplankton toward the bottom. In 1993, the dominant phytoplankton species in Blue Lake were the dinoflagellate Glenodinium, a Chlamydomonas-like green algae, and several silicious species including Kephyrion spirale, Diatoma, and Nitzschia palea (Baker 1995). Silicon concentrations in Blue Lake were nearly as high as the lakes within the blast zone, possibly from inputs of ashfall from the 1980 eruption. At these plentiful concentrations, it is highly doubtful that Si would limit the growth of diatomaceous phytoplankton.

\section{Nutrient Ratios}

In August 1993, nutrient ratios provide evidence for limitation by $\mathrm{N}$ in Blue Lake. DIN:SRP ratios were low in the epilimnion and metalimnion (2.1 and 2.5 , respectively). The DIN:SRP in the hypolimnion (7.6) approached Redfield values (7.2), indicating a balanced proportion of $\mathrm{N}$ to $\mathrm{P}$. The TN:TP ratios in the epilimnion and metalimnion were low (2.3 and 2.4 ), respectively, further indicating $\mathrm{N}$ limitation

\section{Conclusion}

The relatively limited availability of $\mathrm{N}$ compared to $\mathrm{P}$ in the epilimnion and metalimnion of Blue Lake suggests limitation by N. Ratios of nutrient availability and total nutrients confirms this conclusion, although physiological measures of nutrient limitation are lacking for this lake. 
Table 27. Nutrient Concentrations and Ratios and Chlorophyll a Concentrations in Blue Lake (7-11-93). Values \pm 1 standard deviation.

\begin{tabular}{|c|c|c|c|c|c|c|c|c|c|c|}
\hline $\begin{array}{l}\text { Depth } \\
\text { (m) }\end{array}$ & $\begin{array}{l}\text { Chl. a } \\
(\mu g /)\end{array}$ & $\begin{array}{c}\text { SRP } \\
(\mu g / 1)\end{array}$ & $\underset{(\mu \mathrm{g} / 1)}{\mathrm{TP}}$ & $\begin{array}{c}\mathrm{NO}_{3}+\mathrm{NO}_{2} \\
(\mu g \mathcal{1})\end{array}$ & $\begin{array}{l}\mathrm{NH}_{4} \\
(\mu \mathrm{g} /)\end{array}$ & $\begin{array}{c}\text { TN } \\
(\mu g /)\end{array}$ & $\begin{array}{l}\mathrm{SiO}_{2} \\
(\mathrm{mg} / 1)\end{array}$ & $S R N^{3}: S R P$ & $S R N^{3}: T P$ & TN:TP \\
\hline 1 & 15.8 & $\begin{array}{l}6.0 \\
\pm 0\end{array}$ & 19.2 & $\begin{array}{c}6.5 \\
\pm 0.3\end{array}$ & $\begin{array}{l}6.2 \\
\pm 0\end{array}$ & 44.8 & $\begin{array}{l}5.7 \\
\pm 0\end{array}$ & 2.11 & 0.68 & 2.34 \\
\hline 10 & 31.6 & $\begin{array}{l}6.0 \\
\pm 0\end{array}$ & 13.7 & $\begin{array}{l}10.5 \\
\pm 0.1\end{array}$ & $\begin{array}{c}4.3 \\
\pm 0.3\end{array}$ & 33.2 & $\begin{array}{l}6.1 \\
\pm 0\end{array}$ & 2.46 & 1.06 & 2.42 \\
\hline 22 & N.D. ${ }^{2}$ & $\begin{array}{c}7.6 \\
\pm 0.4\end{array}$ & 22.1 & $\begin{array}{l}39.1 \\
\pm 2.2\end{array}$ & $\begin{array}{l}18.8 \\
\pm 0.5\end{array}$ & 129.8 & $\begin{array}{l}7.5 \\
\pm 0\end{array}$ & 7.64 & 2.75 & 5.88 \\
\hline
\end{tabular}

${ }^{2} \mathrm{~N} . \mathrm{D}$. No data ${ }^{3} \mathrm{SRN}=\mathrm{NO}_{3}+\mathrm{NO}_{2}+\mathrm{NH}_{4}$

Figure 44. Profiles of Temperature and Oxygen and Secchi Disk Depth in Blue Lake (7-11-93).
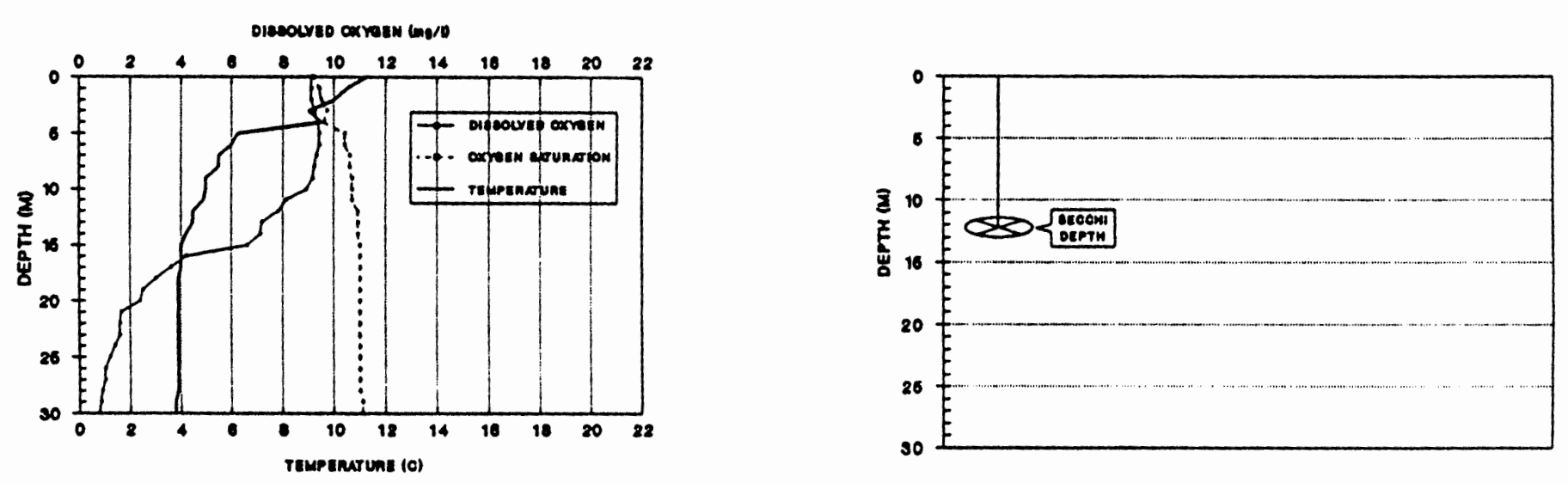


\section{$\underline{\text { June Lake }}$}

June Lake resides in an undisturbed, forested watershed, $6 \mathrm{~km}$ south of Mt. St. Helens at an elevation of $985 \mathrm{~m}$. The lake basin was formed when a basalt flow and landslide from a previous eruption of the mountain blocked the outflow on the south side of the lake. The lake is small and shallow (maximum depth $1.5 \mathrm{~m}$ ) and a large waterfall enters the lake from the north. Consequently, the lake is well mixed, and has a short residence time. Although the lake received only ashfall from the 1980 eruption, elevated concentrations of major cations, silicate, and primary nutrients were found in the lake, suggesting influence by nearby mudflows (Wissmar et al. 1982a).

\section{Temperature, Oxygen, and Light}

Profiles of temperature, oxygen, and light attenuation for June Lake are presented in Figures 46 and 47. In May and October 1993, the lake was isothermal and water temperatures were low $\left(4-5^{\circ} \mathrm{C}\right)$. The prominent waterfall supplies fully aerated cold water to the lake and produces nearly saturated concentrations of dissolved oxygen. During three visits to the lake, the oxygen concentrations were always between 10 and 11 $\mathrm{mg} / \mathrm{lthroughout}$ the water column. June Lake is clear, having an extinction coefficient of $0.24 \mathrm{~m}^{-1}$ and more than $5 \%$ of surface light intensity was available at all depths during this study. 


\section{Nutrient Dynamics}

Concentrations of total and dissolved nutrients, chlorophyll-a and nutrient ratios for June Lake are presented in Tables 28-30. During this study, the SRP concentrations were high, averaging $45.8 \mu \mathrm{g} / \mathrm{l}$ (range $32.6-51.0 \mu \mathrm{g} /$ ). The nitrate + nitrite concentrations averaged $46.9 \mu \mathrm{g} / \mathrm{l}$ (range 40.2 - $54.9 \mu \mathrm{g} / \mathrm{l}$ ) and ammonium concentrations were low, averaging $3.1 \mu \mathrm{g} /$ (range $1.8-6.3 \mu \mathrm{g} /$ ). Since only one depth was sampled on all occasions, uptake of soluble nutrients from the epilimnion was not evaluated, although concentrations of $\mathrm{N}$ and $\mathrm{P}$ were sufficiently high to sustain plankton growth. A decrease in the ammonium concentration did occur from May to September 1993, when concentrations decreased from 6.3 to $1.8 \mu \mathrm{g} /$. The highest concentration of chlorophyll-a during this study was $28.0 \mu \mathrm{g} / \mathrm{l}$ and occurred in September, 1993. Concentrations of nitrate + nitrite increased from $40.2 \mu \mathrm{g} / \mathrm{l}$ in May to $46.1 \mu \mathrm{g} / \mathrm{l}$ in September to $54.9 \mu \mathrm{g} / \mathrm{l}$ in October, 1993. TP averaged $73.8 \mu \mathrm{g} / \mathrm{l}$ and concentrations of TN averaged $44.4 \mu \mathrm{g} /$. Concentrations of Si were also high (always above $20 \mathrm{mg} / \mathrm{l}$ ) in June Lake. Silicon concentrations in June Lake are higher than the lakes located within the blast zone, which may be attributed to the dissolution of silica from nearby mudflows near the lake (Wissmar et al. 1982a). In 1993, the dominant phytoplankton in June Lake were Synedra ulna and Diatoma hiemale mesodon, both periphytic diatoms (Baker 1995). Because Si is so plentiful in June Lake, it is highly doubtful that this nutrient would limit the growth of the diatomaceous phytoplankton.

The chlorophyll-a concentrations varied seasonally in June Lake, with maximum concentrations occurring in September 1995, when $28 \mu \mathrm{g} / \mathrm{l}$ were present at $1 \mathrm{~m}$ depth. 
The lowest chlorophyll-a concentration of $11.2 \mu \mathrm{g} / \mathrm{l}$ occurred in October 1993. At this time, $\mathrm{TN}$ was also at its minimum value of $14.8 \mu \mathrm{g} /$. Since $\mathrm{N}$ is an essential component of chlorophyll-a, chlorophyll-a and TN should be directly related, although the light climate in the lake also influences the chlorophyll-a content of the phytoplankton cells (Wetzel 1986).

\section{Nutrient Ratios}

Nutrient ratios from June Lake indicate that $\mathrm{N}$ is in relatively shorter supply, compared to P. In September 1993, high concentrations of SRP produced a DIN:SRP ratio of 0.9 . During three samplings the DIN:SRP ratio averaged 1.1 range $(0.9-1.4)$. The TN:TP ratio in June Lake ranged from 0.2 to 1.0. These values appear to suggest limitation by $\mathrm{N}$, although considering the abundant concentrations of both $\mathrm{N}$ and $\mathrm{P}$ in the lake, it is likely that cool temperatures or flushing rate control the plankton productivity, rather than nutrient concentrations.

\section{Bioassays}

\section{Alkaline Phosphatase}

Data on alkaline phosphatase enzyme activity (APA) during October 1993 suggests that $P$ is in short supply in June Lake. Plankton collected from $1 \mathrm{~m}$ depth produced a $16 \%$ average (SD 3.9) increase in APA compared to controls (Figure 45). Because concentrations of SRP in June Lake were high, the presence of APA in the lake is 
unexplained, and it is

doubtful that $\mathbf{P}$ limits the

growth of the plankton.

Conclusion

The abundant

concentrations of $\mathrm{N}, \mathrm{P}$, and

$\mathrm{Si}$ in June Lake precludes

limitation by any of these

nutrients at this time.

Slightly elevated APA in the

lake is not explained,

although APA in the lake

was less than all the other lakes in this study. It is more likely that the cool temperatures or a short residence time limits plankton productivity.
Alkaline Phosphatase Activity

June Lake October 1993

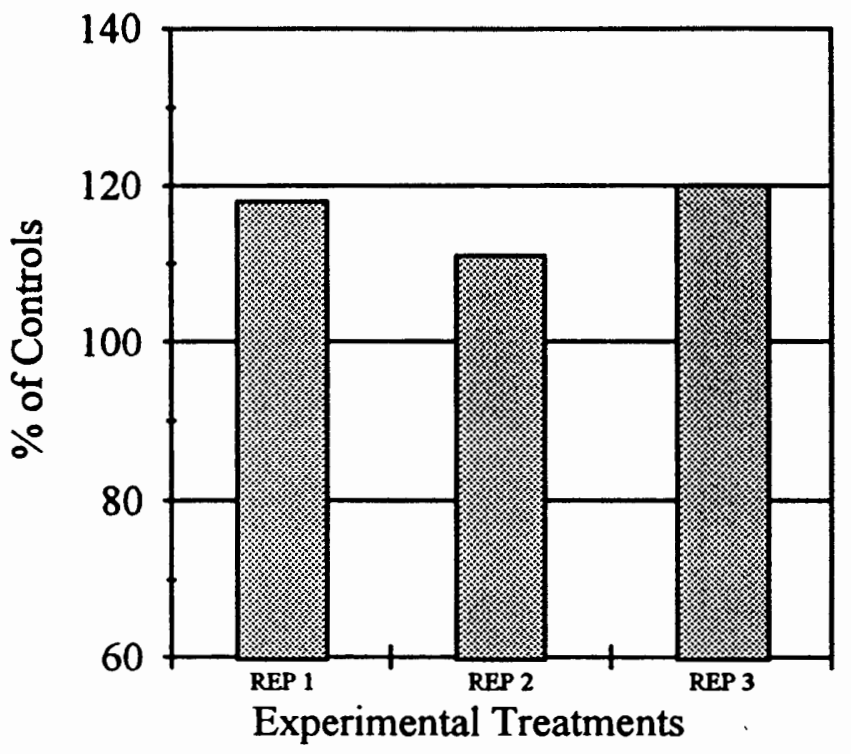

Figure 45 
Table 28. Nutrient Concentrations and Ratios and Chlorophyll a Concentrations in June Lake (5-28-93). Values \pm 1 standard deviation.

\begin{tabular}{|c|c|c|c|c|c|c|c|c|c|c|}
\hline $\begin{array}{l}\text { Depth } \\
\text { (m) }\end{array}$ & $\begin{array}{l}\text { Chl. a } \\
(\mu \mathrm{g} /)\end{array}$ & $\begin{array}{c}\mathrm{SRP} \\
(\mu \mathrm{g} / \mathrm{I})\end{array}$ & $\begin{array}{c}\mathrm{TP} \\
(\mu \mathrm{g} /)\end{array}$ & $\begin{array}{c}\mathrm{NO}_{3}+\mathrm{NO}_{2} \\
(\mu \mathrm{g} /)\end{array}$ & $\begin{array}{l}\mathrm{NH}_{4} \\
(\mu \mathrm{g} /)\end{array}$ & $\begin{array}{c}\mathrm{TN} \\
(\mu \mathrm{g} / \mathrm{I})\end{array}$ & $\begin{array}{l}\mathrm{SiO}_{2} \\
(\mathrm{mg} / \mathrm{l})\end{array}$ & $S R N^{3}: S R P$ & $S R N^{3}: T P$ & TN:TP \\
\hline 0.5 & $\begin{array}{l}22.1 \\
\pm 3.0\end{array}$ & $\begin{array}{l}32.6 \\
\pm 5.1\end{array}$ & N.D. ${ }^{2}$ & $\begin{array}{l}40.2 \\
\pm 2.0\end{array}$ & $\begin{array}{l}6.3 \\
\pm 0\end{array}$ & N.D. ${ }^{2}$ & $\begin{array}{l}20.6 \\
\pm 3.4\end{array}$ & 1.4 & N.D. ${ }^{2}$ & N.D. ${ }^{2}$ \\
\hline
\end{tabular}

${ }^{2}$ N.D. No data ${ }^{3} \mathrm{SRN}=\mathrm{NO}_{3}+\mathrm{NO}_{2}+\mathrm{NH}_{4}$

Figure 46. Profiles of Temperature and Oxygen in June Lake (5-28-93).

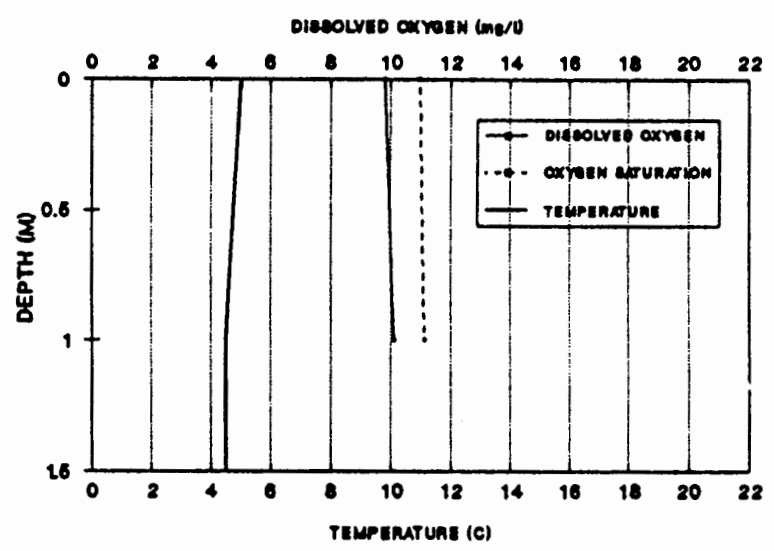


Table 29. Nutrient Concentrations and Ratios and Chlorophyll a Concentrations in June Lake (9-9-93). Values \pm 1 standard deviation.

\begin{tabular}{|c|c|c|c|c|c|c|c|c|c|c|}
\hline $\begin{array}{l}\text { Depth } \\
\text { (m) }\end{array}$ & $\begin{array}{l}\text { Chl. a } \\
(\mu g / l)\end{array}$ & $\begin{array}{c}\mathrm{SRP} \\
(\mu g /)\end{array}$ & $\underset{(\mu \mathrm{g} /)}{\mathrm{TP}}$ & $\begin{array}{c}\mathrm{NO}_{3}+\mathrm{NO}_{2} \\
(\mu \mathrm{g} /)\end{array}$ & $\begin{array}{l}\mathrm{NH}_{4} \\
(\mu \mathrm{g} / \mathrm{l})\end{array}$ & $\begin{array}{c}\mathrm{TN} \\
(\mu g /)\end{array}$ & $\begin{array}{l}\mathrm{SiO}_{2} \\
(\mathrm{mg} / \mathrm{l})\end{array}$ & SRN ${ }^{3}: S R P$ & SRN $: T P$ & TN:TP \\
\hline 1 & $\begin{array}{c}28.0^{1} \\
\pm 6.1\end{array}$ & $\begin{array}{l}51.0 \\
\pm 0.2\end{array}$ & $\begin{array}{l}74.1 \\
\pm 1.0\end{array}$ & $\begin{array}{l}46.1 \\
\pm 0.2\end{array}$ & $\begin{array}{c}1.8 \\
\pm 0.1\end{array}$ & $\begin{array}{l}74.1 \\
\pm 5.4\end{array}$ & $>24$ & 0.9 & 0.6 & 1.0 \\
\hline
\end{tabular}

${ }^{1}$ Questionable data (standard deviation $>\left(\right.$ value) ${ }^{1 / 2}$ ) ${ }^{2} \mathrm{~N} . \mathrm{D}$. No data ${ }^{3} \mathrm{SRN}=\mathrm{NO}_{3}+\mathrm{NO}_{2}+\mathrm{NH}_{4}$ 
Table 30. Nutrient Concentrations and Ratios and Chlorophyll a Concentrations in June Lake (10-17-93). Values \pm 1 standard deviation.

\begin{tabular}{|c|c|c|c|c|c|c|c|c|c|c|}
\hline $\begin{array}{l}\text { Depth } \\
\text { (m) }\end{array}$ & $\begin{array}{l}\text { Chl. a } \\
(\mu g / 1)\end{array}$ & $\begin{array}{c}\text { SRP } \\
(\mu g /)\end{array}$ & $\underset{(\mu \& / 1)}{\operatorname{TP}}$ & $\begin{array}{c}\mathrm{NO}_{3}+\mathrm{NO}_{2} \\
(\mu \mathrm{g} /)\end{array}$ & $\begin{array}{l}\mathrm{NH}_{4} \\
(\mu \mathrm{g} / 1)\end{array}$ & $\begin{array}{c}\text { TN } \\
(\mu g /)\end{array}$ & $\begin{array}{l}\mathrm{SiO}_{2} \\
(\mathrm{mg} / \mathrm{l})\end{array}$ & SRN'SRP & $S R N^{3}: T P$ & TN:TP \\
\hline 1 & $\begin{array}{l}11.2^{1} \\
\pm 3.9\end{array}$ & $\begin{array}{l}49.0 \\
\pm 0\end{array}$ & $\begin{array}{l}73.5 \\
\pm 1.2\end{array}$ & $\begin{array}{l}54.9 \\
\pm 2.4\end{array}$ & $\begin{array}{c}4.4 \\
\pm 0.5\end{array}$ & $\begin{array}{l}14.8^{1} \\
\pm 4.6\end{array}$ & $>24$ & 1.2 & 0.8 & $0.2^{1}$ \\
\hline
\end{tabular}

${ }^{1}$ Questionable data (standard deviation $>(\text { value })^{1 / 2}$ ) ${ }^{2} \mathrm{~N} . \mathrm{D}$. No data ${ }^{3} \mathrm{SRN}=\mathrm{NO}_{3}+\mathrm{NO}_{2}+\mathrm{NH}_{4}$

Figure 47. Profiles of Temperature, Oxygen, and Light Attenuation in June Lake (10-17-93).
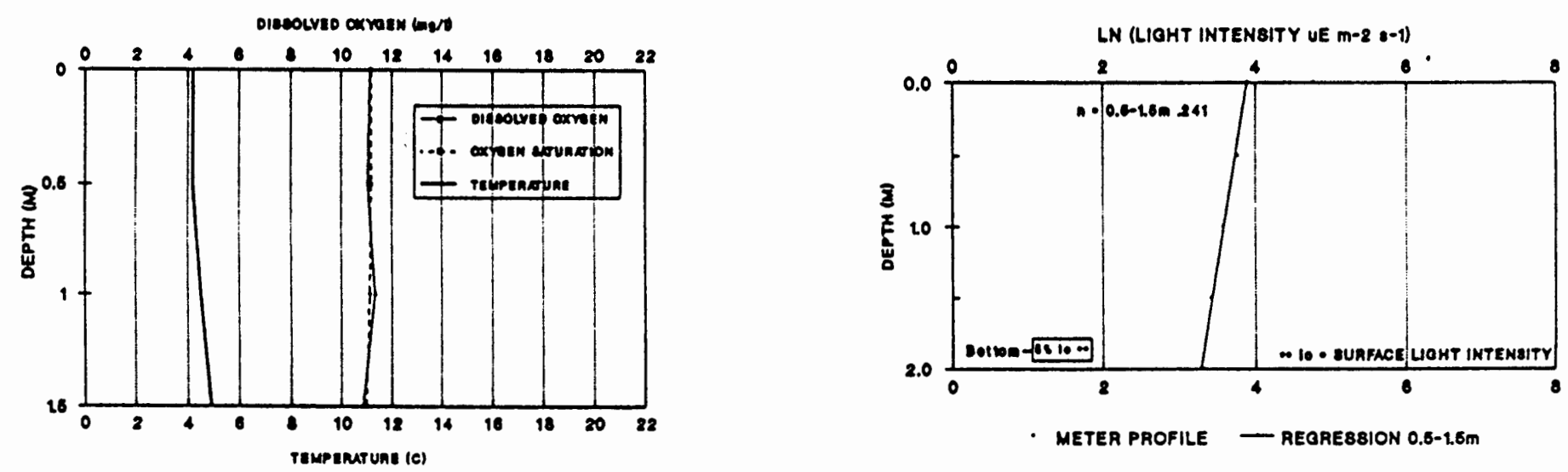


\section{McBride Lake}

McBride Lake resides in an undisturbed, forested watershed, $9 \mathrm{~km}$ southwest of Mt. St. Helens at an elevation of $862 \mathrm{~m}$. This small and shallow lake (area $3.6 \mathrm{ha}$; maximum depth $2 \mathrm{~m}$ ) flows into the Kalama River, a tributary to the Columbia River. The lake received only ashfall from the 1980 enuption and was considered a "control" lake.

\section{Temperature, Oxygen, and Light}

Profiles of temperature, oxygen, and light attenuation for McBride Lake are presented in Figures 49-51. Because of its shallow depth, the lake circulates often and does not stratify with respect to temperature. During all three visits, the lake was nearly isothermal. Surface water temperatures in the lake were cool but relatively elevated, ranging from $9-18{ }^{\circ} \mathrm{C}$ and bottom temperatures were always greater than $8^{\circ} \mathrm{C}$.

Frequent circulation of the lake produces high dissolved oxygen concentrations. Oxygen concentrations were nearly saturated in the lake and were always above $90 \%$ saturation. In August 1993, oxygen concentrations were elevated an at $1.5 \mathrm{~m}$ depth and reached $128 \%$ saturation. These data suggest active populations of phytoplankton in the lake. In 1993, 16 species of phytoplankters were identified in the lake (Baker 1995).

Water transparency is limited in McBride Lake. In 1993, the average extinction coefficient was $0.71 \mathrm{~m}^{-1}$ (range $0.33-.937 \mathrm{~m}^{-1}$ ). The Secchi disk depth was $1.6 \mathrm{~m}$ in October, 1993. Despite this, $5 \%$ surface light intensity was always available throughout the lake. These data suggest a mesotrophic classification for McBride Lake. 


\section{Nutrient Dynamics}

Concentrations of total and dissolved nutrients, chlorophyll-a and nutrient ratios for McBride Lake are presented in Tables 31-33. During three samplings in 1993, the SRP concentrations were low, averaging $5.4 \mu \mathrm{g} /$ (range $4.0 \mu \mathrm{g} / \mathrm{l}-7.3 \mu \mathrm{g} / \mathrm{l}$ ). Nitrogen concentrations were also low in the lake. The nitrate + nitrite concentration averaged 12.7 $\mu \mathrm{g} /$ (range $0.8-28.6 \mu \mathrm{g} /$ ) and ammonium concentrations averaged $3.4 \mu \mathrm{g} /$ (range 1.0 $6.7 \mu \mathrm{g} /)$.

During summer months, concentrations of combined DIN indicate uptake of $\mathrm{N}$. In May 1993, the DIN concentration was $35 \mu \mathrm{g} /$. In August and October 1993, the concentration of DIN decreased to 13 and $4 \mu \mathrm{g} /$, respectively. The concentration of chlorophyll-a was the lowest $(13.4 \mu \mathrm{g} / \mathrm{l})$ when the ammonium concentration decreased to $1 \mu \mathrm{g} / \mathrm{l}$ in August. This decline in chlorophyll-a may be caused by the onset of $\mathrm{N}$ limitation.

Concentrations of SRP were reduced from May to September, although concentrations were consistent through the summer and into the fall. SRP decreased from $7.3 \mu \mathrm{g} / \mathrm{l}$ in May to $4.0 \mu \mathrm{g} / \mathrm{l}$ in August 1993. SRP did not decrease from August to October, even though DIN concentrations did decline. This suggests that sufficient amounts of $\mathbf{P}$ were available for plankton growth and that $\mathbf{P}$ is not limiting in McBride Lake.

The relative proportions of ammonium : nitrate + nitrite varied through the year. In May and August 1993, nitrate + nitrite was more abundant, while ammonium prevailed in October. Reducing conditions in the bottom sediments would favor ammonium but 
have been difficult to evaluate using an oxygen probe because frequent mixing could obscure anoxic conditions in the sediments. Another plausible source of ammonium is nitrogen fixation by the cyanophyte Anabaena, which may have been a source of $\mathrm{N}$. In 1991, Anabaena was the second most abundant phytoplankton in McBride Lake and may continue to grow successfully in the lake when DIN concentrations become limiting.

Concentrations of Si remained high throughout the year, and were always above $8.2 \mathrm{mg} /$. Silica concentrations were lowest $(8.2 \mathrm{mg} / \mathrm{l})$ in May 1993 and increased through the year. Following spring turnover, enhanced nutrient availability coupled with low water temperatures may have favored the presence of diatoms, which often bloom during these conditions (Tilman et al. 1986). The dominant phytoplankton species in 1993 (in terms of biovolume) was the small flagellate Cryptomonas erosa and the silicious Chrysophyte Dinobryon (Baker 1995). As DIN concentrations decreased and temperatures increased, cyanophytes would be favored (Tilman et al. 1986). Such successional changes in the phytoplankton community toward green or blue-green algae could account for the increase in Si concentrations apparent in August and October 1993, when concentrations increased to 8.8 and $11.2 \mathrm{mg} / \mathrm{l}$, respectively. Because $\mathrm{Si}$ is so plentiful in McBride Lake, it is doubtful that this nutrient would limit the growth of diatomaceous phytoplankton.

Chlorophyll-a concentrations were relatively higher in May $1993(30.4 \mu \mathrm{g} / \mathrm{l})$, when abundant $\mathrm{N}$ and $\mathrm{P}$ were present. In August, the chlorophyll-a concentration declined to $13.4 \mu \mathrm{g} /$, when DIN concentrations were declining. Chlorophyll-a concentrations subsequently increased to $29.7 \mu \mathrm{g} / \mathrm{l}$ in October. A shift in the phytoplankton community in the fall toward nitrogen fixers (e.g. cyanophytes) may have provided additional $\mathrm{N}$ to the 
lake, allowing further growth (and chlorophyll-a production). The limited DIN supply coupled with increased water temperatures would favor nitrogen fixing phytoplankton (Tilman et al. 1986).

\section{Nutrient Ratios}

DIN:SRP ratios for McBride Lake during 1993 provide additional evidence for $\mathrm{N}$ limitation. The DIN:SRP ratio was 4 in May 1993 and decreased steadily throughout the year. The DIN:SRP ratio was 3.3 in August and 0.8 in October 1993. These data indicate $\mathrm{N}$ limitation in McBride Lake. During this study the average TN:TP ratio was 7.4 and closely approximated the Redfield value of 7.2.

Bioassays

Alkaline Phosphatase

Data on alkaline

phosphatase enzyme activity (APA) during October 1993 appear to suggest that $P$ is in short supply in McBride Lake (Figure 48). Plankton collected from $1 \mathrm{~m}$ depth produced a $17 \%$ average (SD

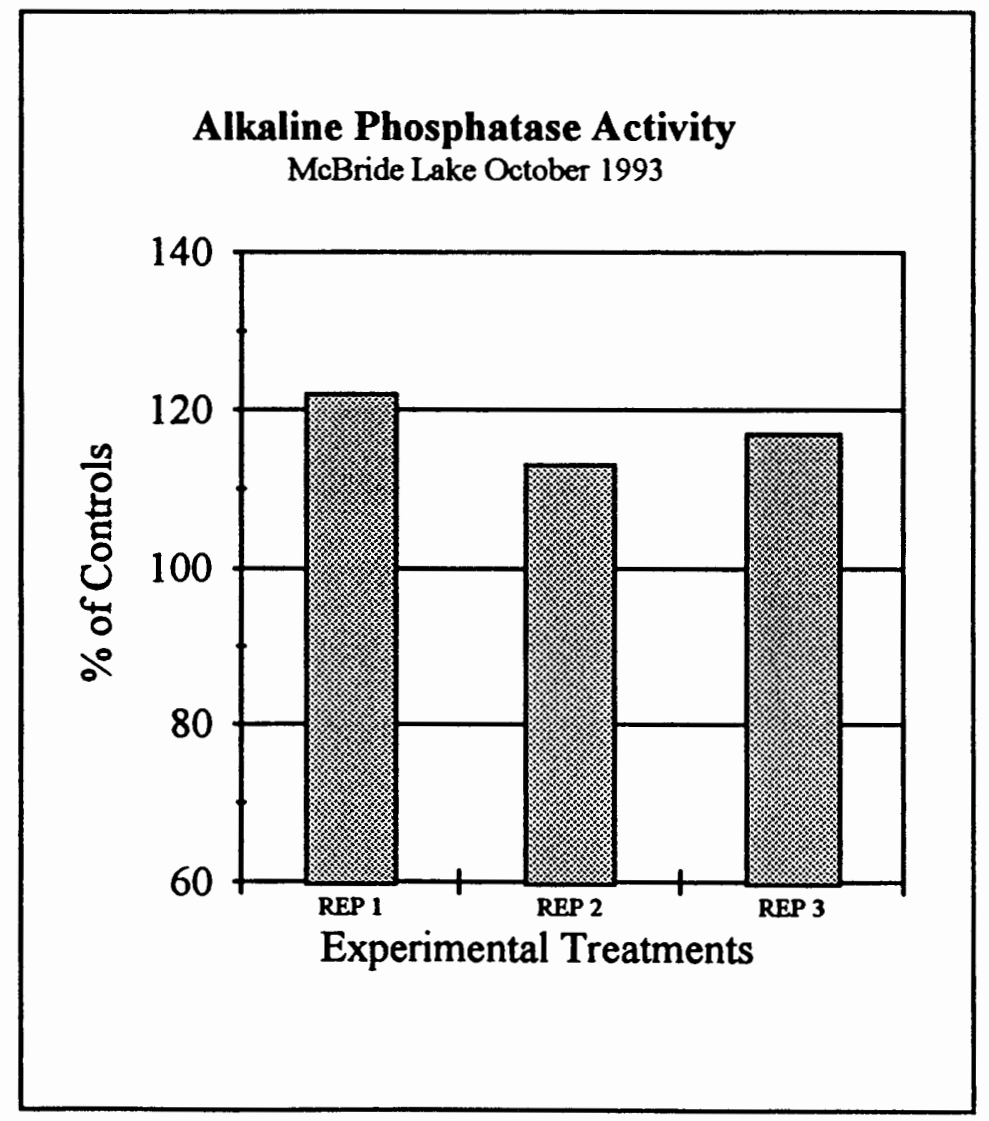

Figure 48 
3.7) increase in APA compared to blank controls. This APA was closely similar to that found in June Lake ( $16 \%$ increase), which had high concentrations of SRP (45 $\mu \mathrm{g} / 1)$. This data suggests that the plankton are not $\mathrm{P}$ deficient in McBride Lake.

\section{Conclusion}

Nutrient concentrations and ratios indicate low DIN availability in McBride Lake, particularly as the growing season progressed into the fall. Further, the presence of nitrogen fixers in the lake would provide a mechanism for the increased ammonium and chlorophyll-a concentrations found in October 1993. Together with evidence from alkaline phosphatase activity, these data suggest limitation by $\mathrm{N}$ in $\mathrm{McBride}$ Lake. 
Table 31. Nutrient Concentrations and Ratios and Chlorophyll a Concentrations in McBride Lake (5-28-93). Values \pm 1 standard deviation.

\begin{tabular}{|c|c|c|c|c|c|c|c|c|c|c|}
\hline $\begin{array}{l}\text { Depth. } \\
\text { (m) }\end{array}$ & $\begin{array}{l}\mathrm{Chl} . \mathrm{a} \\
(\mu \mathrm{g} /)\end{array}$ & $\begin{array}{c}\text { SRP } \\
(\mu g / 1)\end{array}$ & $\underset{(\mu g /)}{\text { TP }}$ & $\begin{array}{c}\mathrm{NO}_{3}+\mathrm{NO}_{2} \\
(\mu \mathrm{g} I)\end{array}$ & $\begin{array}{l}\mathrm{NH}_{4} \\
(\mu g /)\end{array}$ & $\underset{(\mu \mathrm{g} /)}{\mathrm{TN}}$ & $\begin{array}{l}\mathrm{SiO}_{2} \\
(\mathrm{mg} /)\end{array}$ & SRN ${ }^{3}: S R P$ & SRN:TP & TN:TP \\
\hline 1 & $\begin{array}{r}30.4^{1} \\
\pm 8.6\end{array}$ & $\begin{array}{c}7.3 \\
\pm 0.1\end{array}$ & N.D. ${ }^{2}$ & $\begin{array}{l}28.6^{1} \\
\pm 6.2\end{array}$ & $\begin{array}{l}6.7 \\
\pm 0\end{array}$ & N.D. ${ }^{2}$ & $\begin{array}{l}8.2 \\
\pm 0\end{array}$ & $4.8^{1}$ & N.D. ${ }^{2}$ & N.D. ${ }^{2}$ \\
\hline 1.75 & $\begin{array}{l}34.0^{1} \\
\pm 14.0\end{array}$ & $\begin{array}{c}7.2 \\
\pm 0.6\end{array}$ & N.D. ${ }^{2}$ & $\begin{array}{l}21.0^{1} \\
\pm 0.1\end{array}$ & $\begin{array}{c}4.2 \\
\pm 0.5\end{array}$ & N.D. ${ }^{2}$ & $\begin{array}{l}8.2 \\
\pm 0\end{array}$ & $3.5^{1}$ & N.D. ${ }^{2}$ & N.D. ${ }^{2}$ \\
\hline
\end{tabular}

${ }^{1}$ Questionable data (standard deviation $>\left(\right.$ value ${ }^{1 / 2}$ ) ${ }^{2} \mathrm{~N} . \mathrm{D}$. No data ${ }^{3} \mathrm{SRN}=\mathrm{NO}_{3}+\mathrm{NO}_{2}+\mathrm{NH}_{4}$

Figure 49. Profiles of Temperature, Oxygen, and Light Attenuation in McBride Lake (5-28-93).
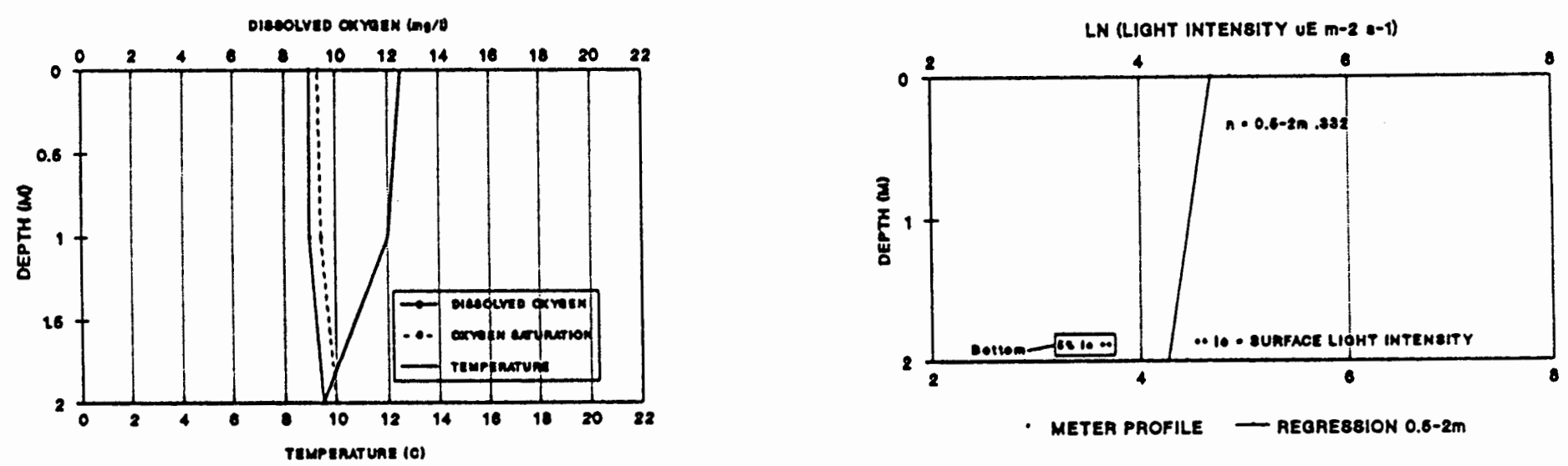
Table 32. Nutrient Concentrations and Ratios and Chlorophyll a Concentrations in McBride Lake (9-9-93). Values \pm 1 standard deviation.

\begin{tabular}{|c|c|c|c|c|c|c|c|c|c|c|}
\hline $\begin{array}{l}\text { Depth } \\
\text { (m) }\end{array}$ & $\begin{array}{l}\text { Chl. a } \\
(\mu g / l)\end{array}$ & $\begin{array}{c}\text { SRP } \\
(\mu g / 1)\end{array}$ & $\begin{array}{c}\text { TP } \\
(\mu g / 1)\end{array}$ & $\begin{array}{c}\mathrm{NO}_{3}+\mathrm{NO}_{2} \\
(\mu \mathrm{g} \Omega)\end{array}$ & $\begin{array}{l}\mathrm{NH}_{4} \\
(\mu \mathrm{g} /)\end{array}$ & $\begin{array}{c}\mathrm{TN} \\
(\mu g / 1)\end{array}$ & $\begin{array}{l}\mathrm{SiO}_{2} \\
(\mathrm{mg} / \mathrm{l})\end{array}$ & $S R N^{3}: S R P$ & $S R N^{3}: T P$ & TN:TP \\
\hline 1 & $\begin{array}{l}13.4 \\
\pm 0.8\end{array}$ & $\begin{array}{c}4.0 \\
\pm 0.3\end{array}$ & $\begin{array}{l}27.9^{1} \\
\pm 5.6\end{array}$ & $\begin{array}{l}12.6^{1} \\
\pm 7.5\end{array}$ & $\begin{array}{l}1.0^{1} \\
\pm 1.2\end{array}$ & $\begin{array}{l}216.7^{1} \\
\pm 46.8\end{array}$ & $\begin{array}{c}8.8 \\
\pm 0.1\end{array}$ & $3.3^{1}$ & $0.3^{1}$ & $8.4^{1}$ \\
\hline
\end{tabular}

${ }^{1}$ Questionable data (standard deviation $>(\text { value })^{1 / 2}$ ) ${ }^{2}$ N.D. No data ${ }^{3} \mathrm{SRN}=\mathrm{NO}_{3}+\mathrm{NO}_{2}+\mathrm{NH}_{4}$

Figure 50. Profiles of Temperature, Oxygen, and Light Attenuation in McBride Lake (9-9-93).
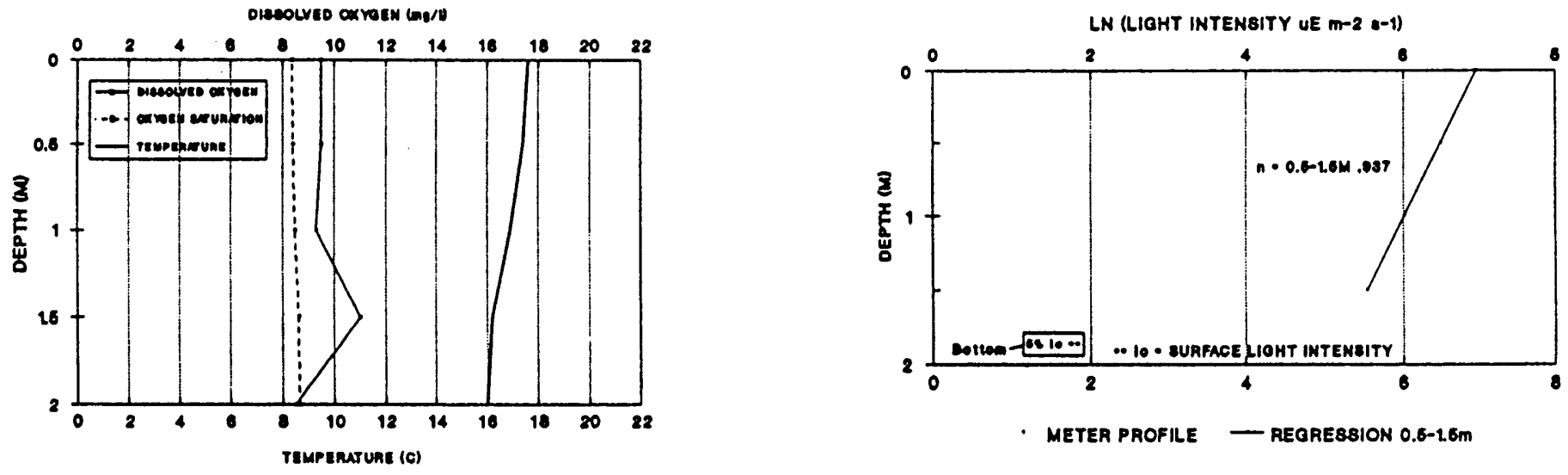
Table 33. Nutrient Concentrations and Ratios and Chlorophyll a Concentrations in McBride Lake (10-17-93). Values \pm 1 standard deviation.

\begin{tabular}{|c|c|c|c|c|c|c|c|c|c|c|}
\hline $\begin{array}{l}\text { Depth } \\
\text { (m) }\end{array}$ & $\begin{array}{l}\text { Chl. a } \\
(\mu \mathrm{g} / \mathrm{l})\end{array}$ & $\begin{array}{c}\text { SRP } \\
(\mu g / 1)\end{array}$ & $\underset{(\mu \mathrm{g} / 1)}{\mathrm{TP}}$ & $\begin{array}{c}\mathrm{NO}_{3}+\mathrm{NO}_{2} \\
(\mu \mathrm{g} / \mathrm{I})\end{array}$ & $\begin{array}{l}\mathrm{NH}_{4} \\
(\mu \mathrm{g} /)\end{array}$ & $\begin{array}{c}\text { TN } \\
(\mu \mathrm{g} /)\end{array}$ & $\begin{array}{l}\mathrm{SiO}_{2} \\
(\mathrm{mg} / \mathrm{l})\end{array}$ & $\mathrm{SRN}^{3}: \mathrm{SRP}$ & $S R N^{3}: T P$ & TN:TP \\
\hline 1 & $\begin{array}{l}29.7 \\
\pm 2.4\end{array}$ & $\begin{array}{c}5.0 \\
\pm 0.2\end{array}$ & $\begin{array}{l}30.1 \\
\pm 0.6\end{array}$ & $\begin{array}{c}0.8 \\
\pm 0.5\end{array}$ & $\begin{array}{c}3.6 \\
\pm 0.7\end{array}$ & $\begin{array}{l}212.9^{1} \\
\pm 14.6\end{array}$ & $\begin{array}{l}11.2 \\
\pm 0.3\end{array}$ & 0.8 & 0.1 & $7.1^{1}$ \\
\hline
\end{tabular}

${ }_{1}^{1}$ Questionable data (standard deviation $>\left(\right.$ value) ${ }^{1 / 2}$ ) ${ }^{2} \mathrm{~N}$.D. No data ${ }^{3} \mathrm{SRN}=\mathrm{NO}_{3}+\mathrm{NO}_{2}+\mathrm{NH}_{4}$

Figure 51. Profiles of Temperature, Oxygen, and Light Attenuation in McBride Lake (10-17-93)
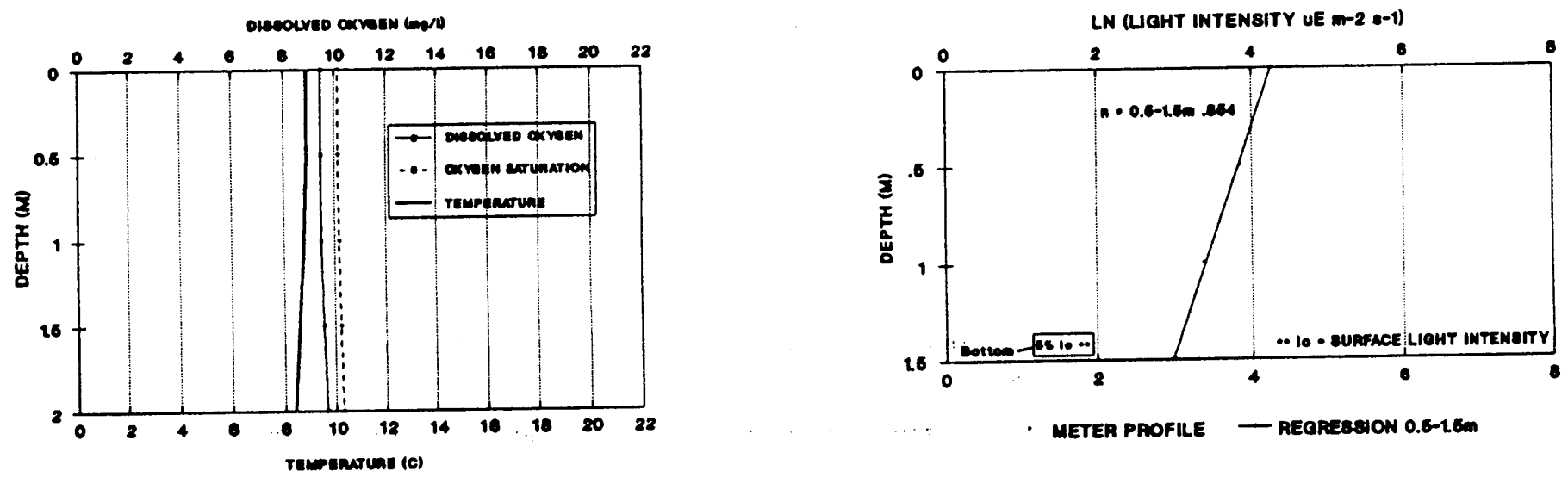


\section{Merrill Lake}

Merrill Lake is located outside the blast zone of Mount St. Helens, $14 \mathrm{~km}$ southwest of the mountain's crater at an elevation of $474 \mathrm{~m}$. The lake level fluctuates seasonally, with the lowest levels occurring late in the summer and the highest in the spring. The lake drains by seepage and flows north to the Kalama River. Merrill Lake received only ashfall from the 1980 eruption and contained similar amounts of major ions and primary nutrients as Spirit Lake before the eruption (Wissmar et al. 1982a). Consequently, the lake represents conditions typical of Cascade lakes. Today, a state park at the lake makes it accessible for swimming and fishing.

\section{Temperature, Oxygen, and Light}

Profiles of temperature, oxygen, and light attenuation for Merrill Lake are presented in Figures 53-58. Having a maximum depth of $18 \mathrm{~m}$, Merrill Lake stratifies during summer months. In August 1993, a thermocline developed at $8 \mathrm{~m}$ when surface temperatures were $21^{\circ} \mathrm{C}$ and bottom temperatures were $11^{\circ} \mathrm{C}$. In April and October 1993 , the lake was nearly isothermal and temperatures were 7 and $15^{\circ} \mathrm{C}$, respectively.

During isothermal conditions, dissolved oxygen concentrations were nearly saturated throughout the lake. During stratification, however, oxygen concentrations declined in the hypolimnion (clinograde oxygen curve). In August 1993, oxygen concentrations in the epilimnion were $9 \mathrm{mg} / \mathrm{l}$ and decreased sharply below $10 \mathrm{~m}$ to 5.4 $\mathrm{mg} / \mathrm{l}(54 \%$ saturation). The clinograde oxygen profile in Merrill Lake is different than 
those from blast zone lakes. Oxygen concentrations in many of the impacted lakes (e.g. Boot, Venus, St. Helens, Fawn Lakes) begin to decline steadily below the metalimnion and often fall to below $1 \mathrm{mg} / \mathrm{l}$. In Merrill Lake, oxygen is nearly saturated in the water column until 1-2 m off the bottom where concentrations begin to decline (always remaining above $4 \mathrm{mg} / \mathrm{l}$ ). This suggests that local oxygen depletion near the bottom results from sediment oxygen demand.

Water transparency in Merrill Lake is high. In 1993, the average extinction coefficient was $0.27 \mathrm{~m}^{-1}$ (range $0.22-0.33 \mathrm{~m}^{-1}$ ) and the Secchi disk depths ranged from $7.3 \mathrm{~m}$ to $8.2 \mathrm{~m}$. The depth of $1 \%$ light intensity varied between 15 and $20 \mathrm{~m}$ during this study. These data indicate oligotrophic condition in Merrill Lake, although the oxygen depletion in the hypolimnion suggests a slightly more productive classification.

\section{Nutrient Dynamics}

Concentrations of total and dissolved nutrients, chlorophyll-a and nutrient ratios for Merrill Lake are presented in Tables 34-39. During three samplings in 1993, the SRP concentrations were low, averaging $1.7 \mu \mathrm{g} / \mathrm{l}$ (range $0.2-3.4 \mu \mathrm{g} / \mathrm{l}$ ). Nitrogen availability in the lake was also low. The average nitrate + nitrite concentration was $4.0 \mu \mathrm{g} / \mathrm{l}$ (range 0.1 $-16.4 \mu \mathrm{g} / \mathrm{l})$ and ammonium concentrations averaged $4.1 \mu \mathrm{g} /($ range $0.0-9.3 \mu \mathrm{g} / \mathrm{l})$.

Concentrations of DIN and SRP were consistently low in Merrill Lake. Nutrient concentrations and chlorophyll-a data suggest a transition from $\mathrm{P}$ limitation in the spring to $\mathrm{N}$ limitation in the summer and fall of 1993. In April 1993, the SRP concentrations were $0.3 \mu \mathrm{g} /$ in the epilimnion and metalimnion and DIN concentrations were higher 
$(12.6 \mu \mathrm{g} / \mathrm{l})$. The chlorophyll-a concentration averaged $29.2 \mu \mathrm{g} / \mathrm{l}$ at this time. The depletion of SRP from the upper waters of the lake suggest that SRP would soon limit the growth of the plankton.

In April 1993, SRP was more abundant $(3.4 \mu \mathrm{g} / \mathrm{l})$ in the hypolimnion and by August 1993, SRP concentrations had increased to $1.9 \mu \mathrm{g} / \mathrm{l}$ in the epilimnion and metalimnion. Reduced oxygen concentrations in the hypolimnia in August suggest reducing conditions in the sediments which may have released $\mathrm{P}$.

In August 1993 concentrations of DNN declined sharply. In the metalimnion, the DIN concentration decreased from $12.6 \mu \mathrm{g} / \mathrm{l}$ in April to $0.8 \mu \mathrm{g} / \mathrm{l}$ in August 1993. This suggests that $\mathrm{N}$ was limiting plankton growth in the summer, although the overall limited availability of both $\mathrm{N}$ and $\mathrm{P}$ suggests colimitation by both nutrients. Chlorophyll-a concentrations were lower in August (near $10 \mu \mathrm{g} /$ ) than in April (near $25 \mu \mathrm{g} / 1$ ). In October 1993, concentrations of DIN and ammonium in particular increased in the lake. The onset of $\mathrm{N}$ limitation in August 1993 would have favored cyanophytes, which are capable of fixing their own N. At this time, the cyanophyte Anabaena accounted for over $60 \%$ of the biovolume in the phytoplankton samples and it is likely that this species is responsible for the increase in ammonium at this time.

Concentrations of $\mathrm{Si}$ remained high throughout the year, and were always above $5.0 \mathrm{mg} / \mathrm{l}$. In 1993, the dominant phytoplankton species in Merrill Lake were Anabaena and the diatom Cyclotella comta (Baker 1995). Because Si is so plentiful in the lake, it is doubtful that this nutrient would limit the growth of diatomaceous phytoplankton. 


\section{Nutrient Ratios}

DIN:SRP ratios for Merrill Lake during 1993 also suggest a shift from $P$ limitation in the spring to $\mathrm{N}$ limitation in the summer and fall. DIN:SRP ratios in April averaged 12.7 in the metalimnion, although ratios were lower ( 8.8 average) in the epilimnion. In August 1993, the small concentrations of DIN in the lake resulted in average DIN:SRP ratios of 0.4 , indicative of severe $\mathrm{N}$ limiting conditions. By October, additional ammonium increased the DIN:SRP ratios slightly (to nearly 1), although ratios continued to indicate $\mathrm{N}$ limitation. In August and October 1993, the average TN:TP ratios were 3.5 and 4.5 , respectively, and also confirm limitation by $\mathrm{N}$.

\section{Bioassays}

\section{Alkaline Phosphatase}

Data on alkaline

phosphatase enzyme activity (APA) during October 1993 suggest that $P$ is in short supply in Merrill Lake (Figure

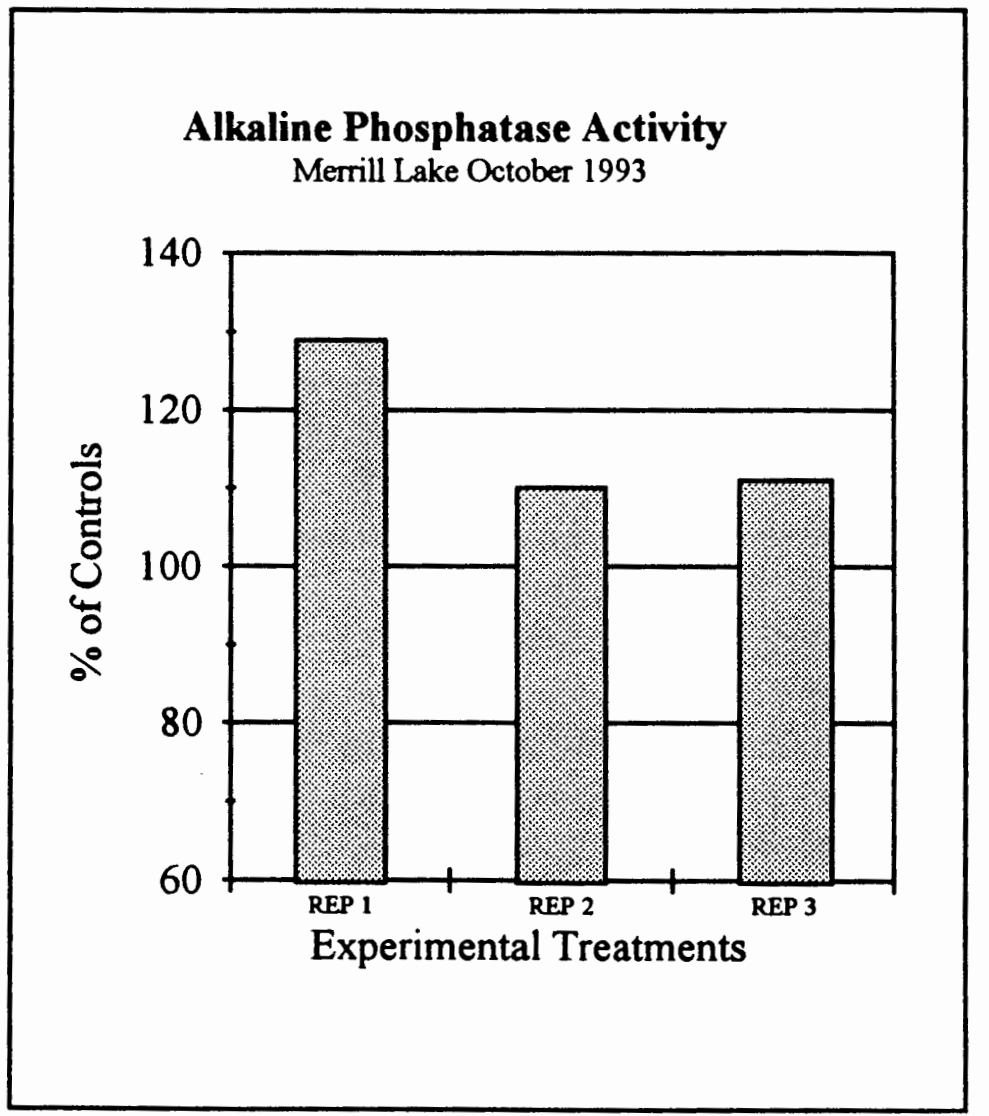

Figure 52

52). Plankton collected from $4 \mathrm{~m}$ depth produced a $17 \%$ average (SD 8.7) increase in 
APA compared to blank controls. In October, the SRP concentration at this depth was $2.8 \mu \mathrm{g} / \mathrm{l}$. These data indicate a shortage of $\mathrm{P}$ in Merrill Lake.

\section{Conclusion}

The data presented above portray a dynamic pattern of nutrient uptake and growth in Merrill Lake. $\mathrm{N}$ and $\mathrm{P}$ concentrations in the lake were always low and indicate colimitation by both $\mathrm{N}$ and $\mathrm{P}$. Nutrient concentrations and ratios imply a shift from $\mathrm{P}$ limited growth in the spring to limitation by $\mathrm{N}$ in the summer and fall. APA in October also indicates a $P$ deficiency. Presently, the lake has a limited amount of nutrients available for plankton growth. 
Table 34. Nutrient Concentrations and Ratios and Chlorophyll a Concentrations in Merrill Lake, Station 1 (4-17-93). Values \pm 1 standard deviation.

\begin{tabular}{|c|c|c|c|c|c|c|c|c|c|c|}
\hline $\begin{array}{l}\text { Depth } \\
\text { (m) }\end{array}$ & $\begin{array}{l}\text { Chl. a } \\
(\mu g /)\end{array}$ & $\begin{array}{c}\text { SRP } \\
(\mu g /)\end{array}$ & $\begin{array}{c}\text { TP } \\
(\mu g /)\end{array}$ & $\begin{array}{c}\mathrm{NO}_{3}+\mathrm{NO}_{2} \\
(\mu g / 1)\end{array}$ & $\begin{array}{l}\mathrm{NH}_{4} \\
(\mu \mathrm{g} / 1)\end{array}$ & $\begin{array}{c}\text { TN } \\
(\mu g / 1)\end{array}$ & $\begin{array}{l}\mathrm{SiO}_{2} \\
(\mathrm{mg} / \mathrm{l})\end{array}$ & $S R N^{3}: S R P$ & SRN'TP & TN:TP \\
\hline 1 & $\begin{array}{l}29.0 \\
\pm 0.4\end{array}$ & $\begin{array}{c}0.4 \\
\pm 0.5\end{array}$ & N.D. ${ }^{2}$ & $\begin{array}{l}1.8 \\
\pm 0.5\end{array}$ & $\begin{array}{l}5.0 \\
\pm 0.5\end{array}$ & N.D. ${ }^{2}$ & $\begin{array}{l}7.2 \\
\pm 0.1\end{array}$ & 7.3 & N.D. ${ }^{2}$ & N.D. ${ }^{2}$ \\
\hline 10 & $\begin{array}{r}23.8 \\
\pm 3.2\end{array}$ & $\begin{array}{c}0.2 \\
\pm 0.4\end{array}$ & N.D. ${ }^{2}$ & $\begin{array}{r}6.3^{1} \\
\pm 2.4\end{array}$ & $\begin{array}{r}6.3^{1} \\
\pm 3.0\end{array}$ & N.D. ${ }^{2}$ & $\begin{array}{c}7.2 \\
\pm 0.1\end{array}$ & $12.9^{1}$ & N.D. ${ }^{2}$ & N.D. ${ }^{2}$ \\
\hline 15 & $\begin{array}{l}30.6 \\
\pm 4.5\end{array}$ & $\begin{array}{l}3.4^{1} \\
\pm 4.1\end{array}$ & N.D. ${ }^{2}$ & $\begin{array}{r}16.4 \\
\pm 3.4\end{array}$ & $\begin{array}{l}8.5^{1} \\
\pm 4.2\end{array}$ & N.D. ${ }^{2}$ & $\begin{array}{c}7.2 \\
\pm 0.3\end{array}$ & $14^{1}$ & N.D. ${ }^{2}$ & N.D. ${ }^{2}$ \\
\hline
\end{tabular}

${ }^{1}$ Questionable data (standard deviation $>(\text { value })^{1 / 2}$ ) ${ }^{2} \mathrm{~N} . \mathrm{D}$. No data ${ }^{3} \mathrm{SRN}=\mathrm{NO}_{3}+\mathrm{NO}_{2}+\mathrm{NH}_{4}$

Figure 53. Profiles of Temperature, Oxygen, and Light Attenuation in Merrill Lake, Station 1 (4-17-93).
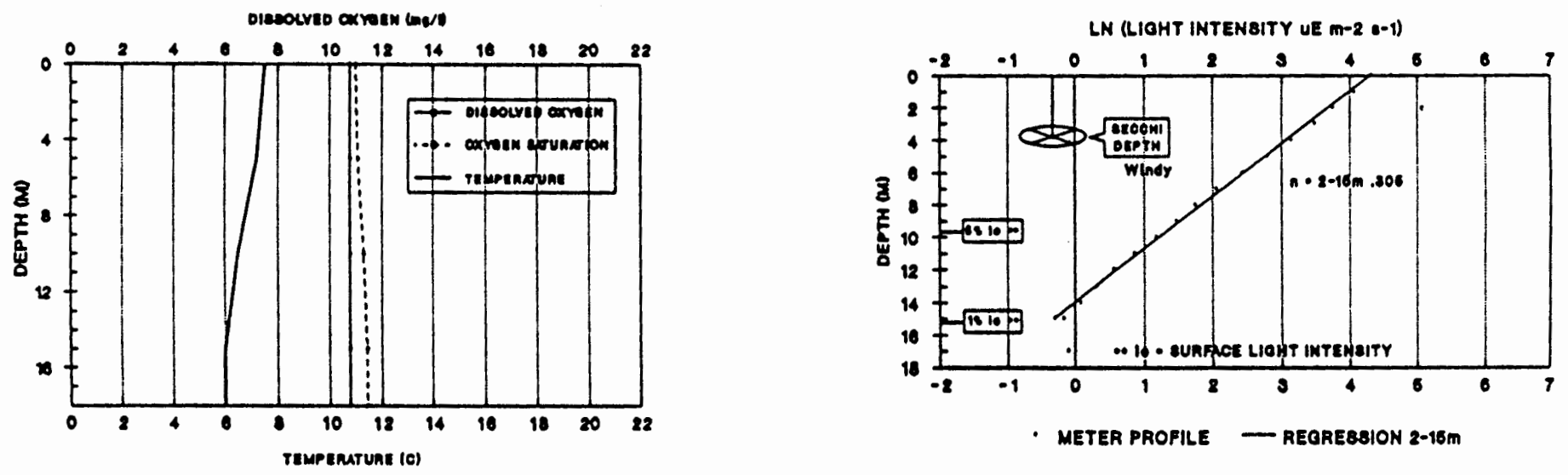
Table 35. Nutrient Concentrations and Ratios and Chlorophyll a Concentrations in Merrill Lake, Station 2 (4-17-93). Values \pm 1 , standard deviation.

\begin{tabular}{|c|c|c|c|c|c|c|c|c|c|c|}
\hline $\begin{array}{l}\text { Depth } \\
\text { (m) }\end{array}$ & $\begin{array}{c}\text { Chl. a } \\
(\mu \mathrm{g} / \mathrm{l})\end{array}$ & $\begin{array}{c}\mathrm{SRP} \\
(\mu \mathrm{g} /)\end{array}$ & $\underset{(\mu g /)}{\operatorname{TP}}$ & $\begin{array}{c}\mathrm{NO}_{3}+\mathrm{NO}_{2} \\
(\mu \mathrm{g} /)\end{array}$ & $\begin{array}{l}\mathrm{NH}_{4} \\
(\mu \mathrm{d} /)\end{array}$ & $\underset{(\mu \mathrm{g} /)}{\mathrm{TN}}$ & $\begin{array}{l}\mathrm{SiO}_{2} \\
(\mathrm{~m} / \mathrm{l})\end{array}$ & $\mathrm{SRN}^{3}: \mathrm{SRP}$ & SRN'TP & TN:TP \\
\hline 1 & $\begin{array}{r}31.7 \\
\pm 2.4\end{array}$ & $\begin{array}{c}0.2 \\
\pm 0.4\end{array}$ & N.D. ${ }^{2}$ & $\begin{array}{c}1.6 \\
\pm 0.8\end{array}$ & $\begin{array}{c}8.3 \\
\pm 2.1\end{array}$ & N.D. ${ }^{2}$ & $\begin{array}{c}7.0 \\
\pm 0.2\end{array}$ & 10.3 & N.D. ${ }^{2}$ & N.D. ${ }^{2}$ \\
\hline 10 & $\begin{array}{r}32.91 \\
\pm 6.9\end{array}$ & $\begin{array}{c}0.4 \\
\pm 0.5\end{array}$ & N.D. ${ }^{2}$ & $\begin{array}{r}4.1 \\
\pm 2.2\end{array}$ & $\begin{array}{r}7.5 \\
\pm 2.4\end{array}$ & N.D. ${ }^{2}$ & $\begin{array}{c}7.1 \\
\pm 0.1\end{array}$ & 12.5 & N.D. ${ }^{2}$ & N.D. ${ }^{2}$ \\
\hline 17 & $\begin{array}{l}20.7 \\
\pm 0.8\end{array}$ & $\begin{array}{c}1.3 \\
\pm 1.6\end{array}$ & N.D. ${ }^{2}$ & $\begin{array}{l}12.3 \\
\pm 0.7\end{array}$ & $\begin{array}{c}9.3 \\
\pm 2.6\end{array}$ & N.D. ${ }^{2}$ & $\begin{array}{c}7.2 \\
\pm 0.1\end{array}$ & 19.4 & N.D. ${ }^{2}$ & N.D. ${ }^{2}$ \\
\hline
\end{tabular}

${ }_{1}^{1}$ Questionable data (standard deviation $>\left(\right.$ value) ${ }^{1 / 2}$ ) ${ }^{2}$ N.D. No data ${ }^{3} \mathrm{SRN}=\mathrm{NO}_{3}+\mathrm{NO}_{2}+\mathrm{NH}_{4}$

Figure 54. Profiles of Temperature and Oxygen in Merrill Lake, Station 2 and Light Attenuation in Merrill Lake, Station 1 (4-17-93).
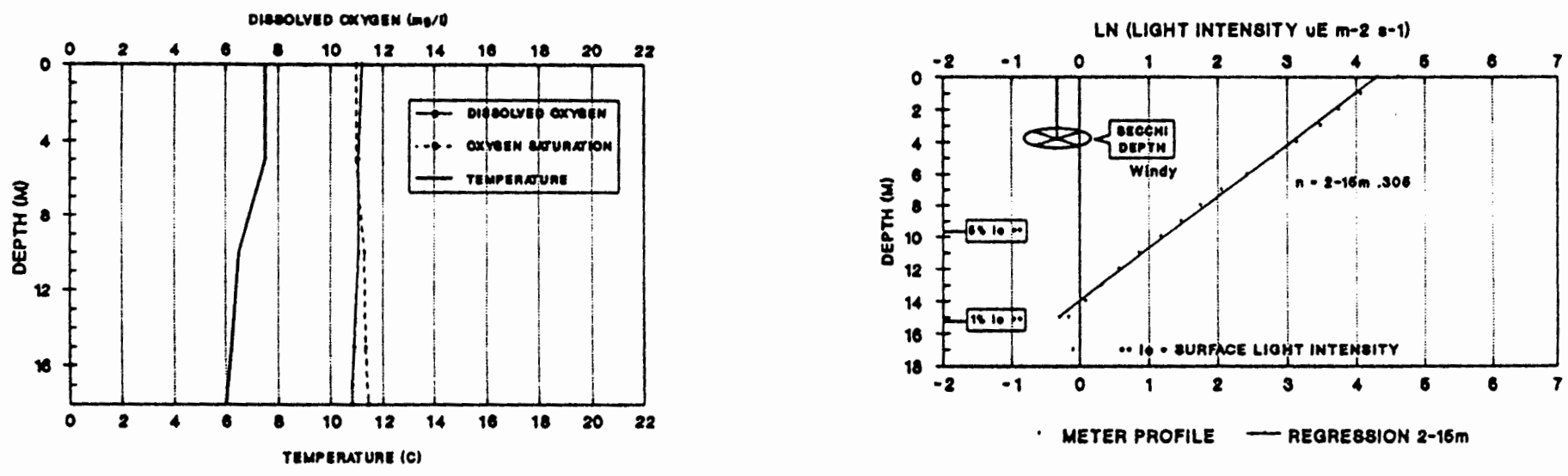
Table 36. Nutrient Concentrations and Ratios and Chlorophyll a Concentrations in Merrill Lake, Station 1 (9-8-93). Values \pm 1 standard deviation.

\begin{tabular}{|c|c|c|c|c|c|c|c|c|c|c|}
\hline $\begin{array}{l}\text { Depth } \\
\text { (m) }\end{array}$ & $\begin{array}{l}\text { Chl. a } \\
(\mu g /)\end{array}$ & $\begin{array}{c}\text { SRP } \\
(\mu g /)\end{array}$ & $\underset{(\mu g /)}{\operatorname{TP}}$ & $\begin{array}{c}\mathrm{NO}_{3}+\mathrm{NO}_{2} \\
(\mu g / 1)\end{array}$ & $\begin{array}{l}\mathrm{NH}_{4} \\
(\mu \mathrm{g} /)\end{array}$ & $\begin{array}{c}\text { TN } \\
(\mu g / l)\end{array}$ & $\begin{array}{l}\mathrm{SiO}_{2} \\
(\mathrm{mg} /)\end{array}$ & SRN'SRP & SRN ${ }^{3}: T P$ & IN:TP \\
\hline 1 & $\begin{array}{c}9.9 \\
\pm 0.2\end{array}$ & $\begin{array}{l}1.9 \\
\pm 0\end{array}$ & $\begin{array}{l}21.9 \\
\pm 1.6\end{array}$ & $\begin{array}{c}0.6 \\
\pm 0.2\end{array}$ & $\begin{array}{l}0.0 \\
\pm 0\end{array}$ & $\begin{array}{l}78.7^{1} \\
\pm 14.2\end{array}$ & $\begin{array}{l}6.4 \\
\pm 0\end{array}$ & 0.3 & 0.03 & $3.6^{1}$ \\
\hline 4 & $\begin{array}{l}10.3 \\
\pm 1.2\end{array}$ & $\begin{array}{c}1.9 \\
\pm 0.3\end{array}$ & $\begin{array}{l}19.7 \\
\pm 1.8\end{array}$ & $\begin{array}{c}0.8 \\
\pm 0.8\end{array}$ & $\begin{array}{l}0.0 \\
\pm 0\end{array}$ & $\begin{array}{l}117.6^{1} \\
\pm 24.7\end{array}$ & $\begin{array}{l}6.4 \\
\pm 0\end{array}$ & 0.5 & 0.04 & $6.1^{1}$ \\
\hline 10 & $\begin{array}{l}33.6 \\
\pm 0.3\end{array}$ & $\begin{array}{l}1.9 \\
\pm 0\end{array}$ & $\begin{array}{l}151.4^{1} \\
\pm 126.7\end{array}$ & $\begin{array}{c}2.1 \\
\pm 1.4\end{array}$ & $\begin{array}{l}0.0 \\
\pm 0\end{array}$ & $\begin{array}{l}105.5^{1} \\
\pm 25.9\end{array}$ & $\begin{array}{l}5.8 \\
\pm 0\end{array}$ & 1.1 & $0.02^{\prime}$ & $1.8^{1}$ \\
\hline
\end{tabular}

${ }_{1}^{1}$ Questionable data (standard deviation $>(\text { value })^{1 / 2}$ ) ${ }^{2} \mathrm{~N} . \mathrm{D}$. No data ${ }^{3} \mathrm{SRN}=\mathrm{NO}_{3}+\mathrm{NO}_{2}+\mathrm{NH}_{4}$

Figure 55. Profiles of Temperature, Oxygen, and Light Attenuation in Merrill Lake, Station 1 (9-8-93).
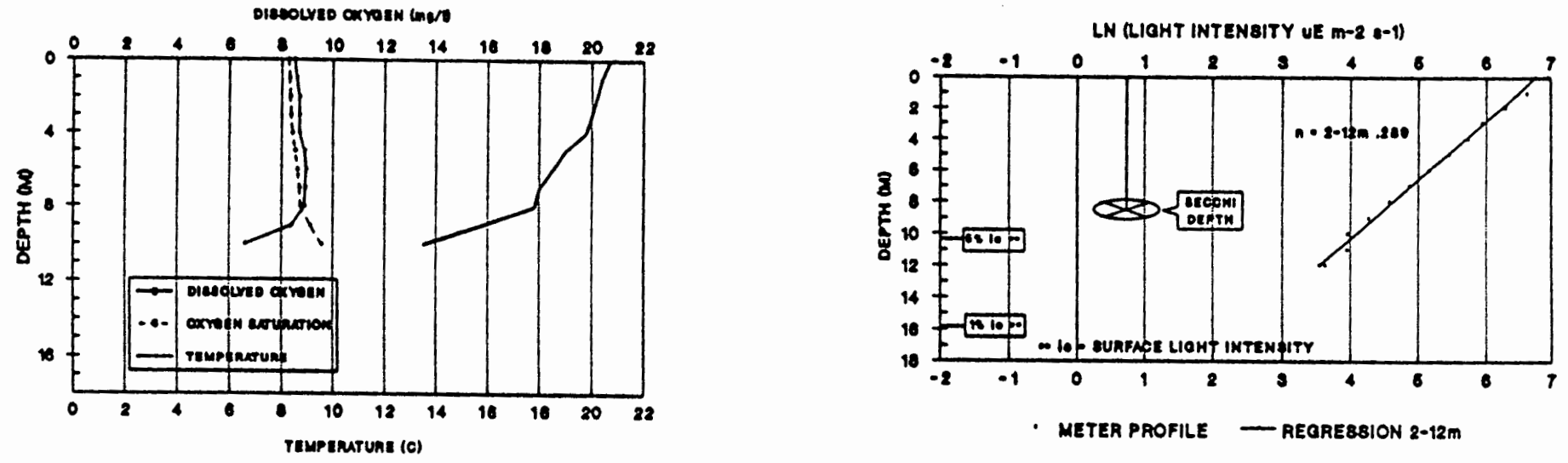
Table 37. Nutrient Concentrations and Ratios and Chlorophyll a Concentrations in Merrill Lake, Station 2 (9-8-93). Values \pm 1 standard deviation.

\begin{tabular}{|c|c|c|c|c|c|c|c|c|c|c|}
\hline $\begin{array}{l}\text { Depth } \\
\text { (m) }\end{array}$ & $\begin{array}{l}\text { Chl. a } \\
(\mu g /)\end{array}$ & $\begin{array}{c}\text { SRP } \\
(\mu g /)\end{array}$ & $\underset{(\mu g /)}{\mathrm{TP}}$ & $\begin{array}{c}\mathrm{NO}_{3}+\mathrm{NO}_{2} \\
(\mu \mathrm{g} /)\end{array}$ & $\begin{array}{l}\mathrm{NH}_{1} \\
(\mu \mathrm{g} / 1)\end{array}$ & $\begin{array}{c}\mathrm{TN} \\
(\mu g /)\end{array}$ & $\begin{array}{l}\mathrm{SiO}_{2} \\
(\mathrm{mg} / \mathrm{l})\end{array}$ & SRN ${ }^{3}: S R P$ & SRN $N^{3}: T P$ & TN:TP \\
\hline 1 & $\begin{array}{l}61.0 \\
\pm 2.9\end{array}$ & $\begin{array}{c}2.1 \\
\pm 0.2\end{array}$ & $\begin{array}{l}26.7 \\
\pm 0.8\end{array}$ & $\begin{array}{c}0.2 \\
\pm 0.2\end{array}$ & $\begin{array}{l}0.0 \\
\pm 0\end{array}$ & $\begin{array}{l}95.9 \\
\pm 0.4\end{array}$ & $\begin{array}{l}6.3 \\
\pm 0\end{array}$ & 0.1 & 0.01 & 3.6 \\
\hline 4 & $\begin{array}{l}59.3 \\
\pm 7.3\end{array}$ & $\begin{array}{c}2.1 \\
\pm 0.2\end{array}$ & $\begin{array}{l}27.7 \\
\pm 0.6\end{array}$ & $\begin{array}{c}0.1 \\
\pm 0.1\end{array}$ & $\begin{array}{l}0.0 \\
\pm 0\end{array}$ & $\begin{array}{l}100.0^{1} \\
\pm 13.8\end{array}$ & $\begin{array}{l}6.4 \\
\pm 0\end{array}$ & 0.1 & 0.0 & $3.6^{1}$ \\
\hline 12 & 33.8 & $\begin{array}{c}2.1 \\
\pm 0.2\end{array}$ & $\begin{array}{l}170.2^{1} \\
\pm 140.3\end{array}$ & $\begin{array}{c}1.3 \\
\pm 0.5\end{array}$ & $\begin{array}{l}0.0 \\
\pm 0\end{array}$ & $\begin{array}{l}110.9^{1} \\
\pm 28.8\end{array}$ & $\begin{array}{c}5.0 \\
\pm 0.1\end{array}$ & 0.6 & $0.02^{1}$ & $2.5^{1}$ \\
\hline
\end{tabular}

${ }^{1}$ Questionable data (standard deviation $>(\text { value })^{1 / 2}$ ) ${ }^{2} \mathrm{~N} . \mathrm{D}$. No data ${ }^{3} \mathrm{SRN}=\mathrm{NO}_{3}+\mathrm{NO}_{2}+\mathrm{NH}_{4}$

Figure 56. Profiles of Temperature and Oxygen in Merrill Lake, Station 2 and Light Attenuation in Merrill Lake, Station 2 (9-8-93).
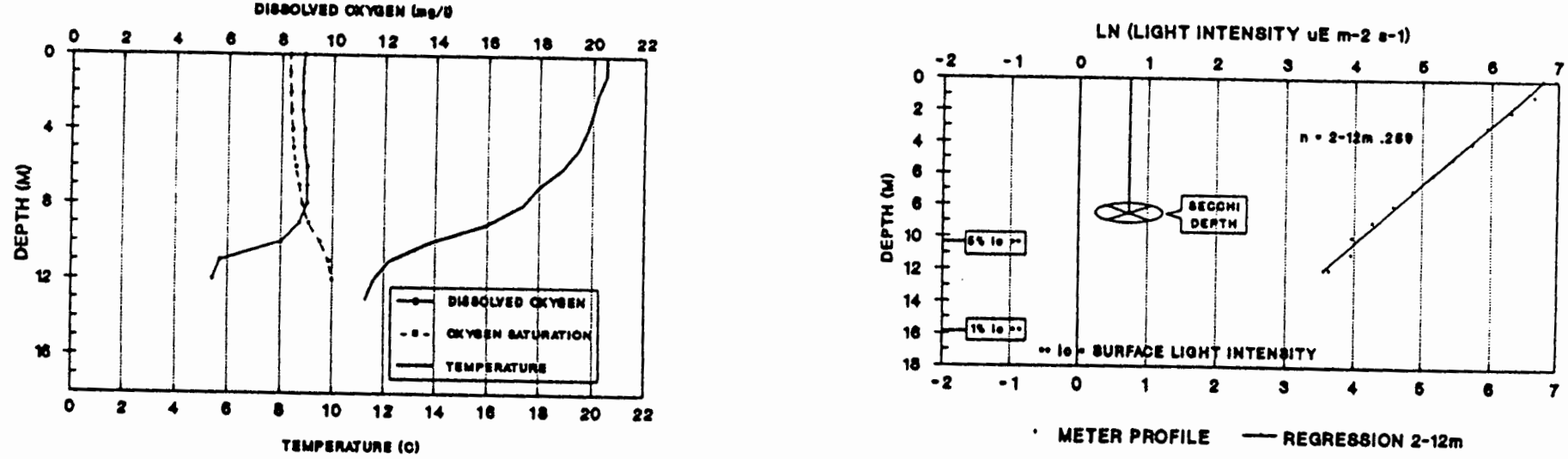
Table 38. Nutrient Concentrations and Ratios and Chlorophyll a Concentrations in Merrill Lake, Station 1 (10-17-93). Values \pm 1 standard deviation.

\begin{tabular}{|c|c|c|c|c|c|c|c|c|c|c|}
\hline $\begin{array}{l}\text { Depth } \\
\text { (m) }\end{array}$ & $\begin{array}{l}\text { Chl. a } \\
(\mu g / 1)\end{array}$ & $\begin{array}{l}\text { SRP } \\
(\mu g /)\end{array}$ & $\begin{array}{c}\mathrm{TP} \\
(\mu g /)\end{array}$ & $\begin{array}{c}\mathrm{NO}_{3}+\mathrm{NO}_{2} \\
(\mu \mathrm{g} / \mathrm{I})\end{array}$ & $\begin{array}{l}\mathrm{NH}_{4} \\
(\mu \mathrm{g} /)\end{array}$ & $\begin{array}{c}\text { IN } \\
(\mu g /)\end{array}$ & $\begin{array}{l}\mathrm{SiO}_{2} \\
(\mathrm{mg} / \mathrm{l})\end{array}$ & $S R N^{3}: S R P$ & $S R N^{\beta}: T P$ & TN:TP \\
\hline 1 & $\begin{array}{r}36.3^{1} \\
\pm 7.9\end{array}$ & $\begin{array}{c}2.8 \\
\pm 0.2\end{array}$ & $\begin{array}{l}28.1 \\
\pm 2.5\end{array}$ & $\begin{array}{c}1.4 \\
\pm 0.1\end{array}$ & $\begin{array}{c}2.1 \\
\pm 0.3\end{array}$ & $\begin{array}{l}64.1^{1} \\
\pm 19.5\end{array}$ & $\begin{array}{l}7.2 \\
\pm 0.1\end{array}$ & 1.2 & 0.1 & $2.3^{1}$ \\
\hline 4 & $\begin{array}{r}24.0^{1} \\
\pm 9.9\end{array}$ & $\begin{array}{c}2.7 \\
\pm 0.2\end{array}$ & $\begin{array}{l}33.3 \\
\pm 0.6\end{array}$ & $\begin{array}{c}0.7 \\
\pm 0.4\end{array}$ & $\begin{array}{c}2.6 \\
\pm 0.2\end{array}$ & $\begin{array}{l}261.0^{2} \\
\pm 167.2\end{array}$ & $\begin{array}{l}7.1 \\
\pm 0\end{array}$ & 1.2 & 0.1 & $7.8^{1}$ \\
\hline 9 & $\begin{array}{l}17.2^{1} \\
\pm 11.0\end{array}$ & $\begin{array}{c}3.0 \\
\pm 0.2\end{array}$ & $\begin{array}{l}30.7 \\
\pm 2.8\end{array}$ & $\begin{array}{c}1.5 \\
\pm 0.2\end{array}$ & $\begin{array}{l}2.4 \\
\pm 0\end{array}$ & $\begin{array}{l}297.0^{9} \\
\pm 248.4\end{array}$ & $\begin{array}{l}7.0 \\
\pm 0\end{array}$ & 1.3 & 0.1 & $10.5^{1}$ \\
\hline
\end{tabular}

${ }^{1}$ Questionable data (standard deviation $>(\text { value })^{1 / 2}$ ) ${ }^{2} \mathrm{~N} . \mathrm{D}$. No data ${ }^{3} \mathrm{SRN}=\mathrm{NO}_{3}+\mathrm{NO}_{2}+\mathrm{NH}_{4}$

Figure 57. Profiles of Temperature and Oxygen in Merrill Lake, Station 1 and Light Attenuation in Merrill Lake, Station 2 (10-1793).
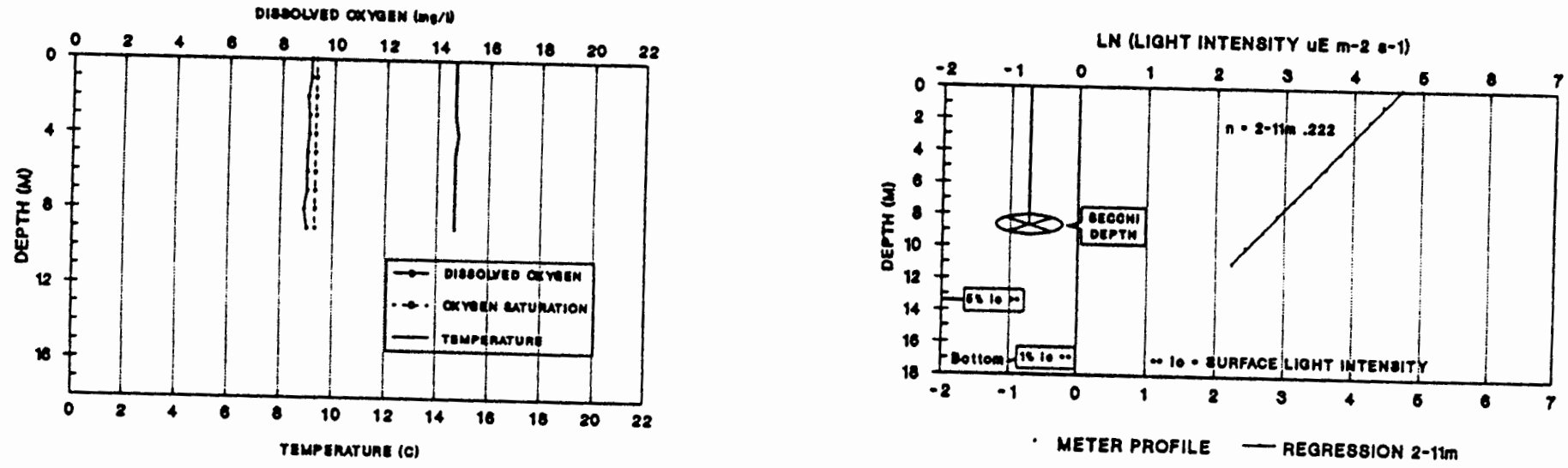
Table 39. Nutrient Concentrations and Ratios and Chlorophyll a Concentrations in Merrill Lake, Station 2 (10-17-93). Values \pm , standard deviation.

\begin{tabular}{|c|c|c|c|c|c|c|c|c|c|c|}
\hline $\begin{array}{l}\text { Depth } \\
\text { (m) }\end{array}$ & $\begin{array}{l}\text { Chl. a } \\
(\mu g /)\end{array}$ & $\begin{array}{l}\text { SRP } \\
(\mu g /)\end{array}$ & $\underset{(\mu g /)}{\mathrm{TP}}$ & $\begin{array}{c}\mathrm{NO}_{3}+\mathrm{NO}_{2} \\
(\mu \mathrm{g} /)\end{array}$ & $\begin{array}{l}\mathrm{NH}_{4} \\
(\mu \mathrm{g} /)\end{array}$ & $\begin{array}{c}\text { TN } \\
(\mu \& /)\end{array}$ & $\begin{array}{l}\mathrm{SiO}_{2} \\
(\mathrm{mgl})\end{array}$ & $S R N^{3}: S R P$ & $\mathrm{SRN}^{3}: \mathrm{TP}$ & TN:TP \\
\hline 1 & $\begin{array}{r}24.3^{1} \\
\pm 5.0\end{array}$ & $\begin{array}{l}2.5 \\
\pm 0\end{array}$ & $\begin{array}{l}33.3 \\
\pm 0.6\end{array}$ & $\begin{array}{c}1.6 \\
\pm 0.1\end{array}$ & $\begin{array}{l}0.9 \\
\pm 0\end{array}$ & $\begin{array}{l}40.7^{1} \\
\pm 8.8\end{array}$ & $\begin{array}{c}7.1 \\
\pm 0.1\end{array}$ & 1.0 & 0.1 & $1.2^{1}$ \\
\hline 4 & $\begin{array}{l}7.9 \\
\pm 1.6\end{array}$ & $\begin{array}{c}3.0 \\
\pm 0.5\end{array}$ & $\begin{array}{l}34.1 \\
\pm 0.2\end{array}$ & $\begin{array}{l}1.9 \\
\pm 0\end{array}$ & $\begin{array}{c}1.6 \\
\pm 1.2\end{array}$ & $\begin{array}{l}64.1^{1} \\
\pm 13.0\end{array}$ & $\begin{array}{l}7.0 \\
\pm 0\end{array}$ & 1.1 & 0.1 & $1.9^{1}$ \\
\hline 11 & $\begin{array}{l}20.1^{1} \\
\pm 10.6\end{array}$ & $\begin{array}{l}2.5 \\
\pm 0\end{array}$ & $\begin{array}{l}32.7 \\
\pm 4.8\end{array}$ & $\begin{array}{c}1.6 \\
\pm 0.3\end{array}$ & $\begin{array}{c}0.8 \\
\pm 0.1\end{array}$ & $\begin{array}{l}99.2^{1} \\
\pm 9.6\end{array}$ & $\begin{array}{l}7.1 \\
\pm 0\end{array}$ & 1.0 & 0.1 & $3.2^{1}$ \\
\hline
\end{tabular}

${ }^{1}$ Questionable data (standard deviation $>\left(\right.$ value) ${ }^{1 / 2}$ ) ${ }^{2}$ N.D. No data ${ }^{3} \mathrm{SRN}=\mathrm{NO}_{3}+\mathrm{NO}_{2}+\mathrm{NH}_{4}$

Figure 58. Profiles of Temperature, Oxygen, and Light Attenuation in Merrill Lake, Station 2 (10-17-93).
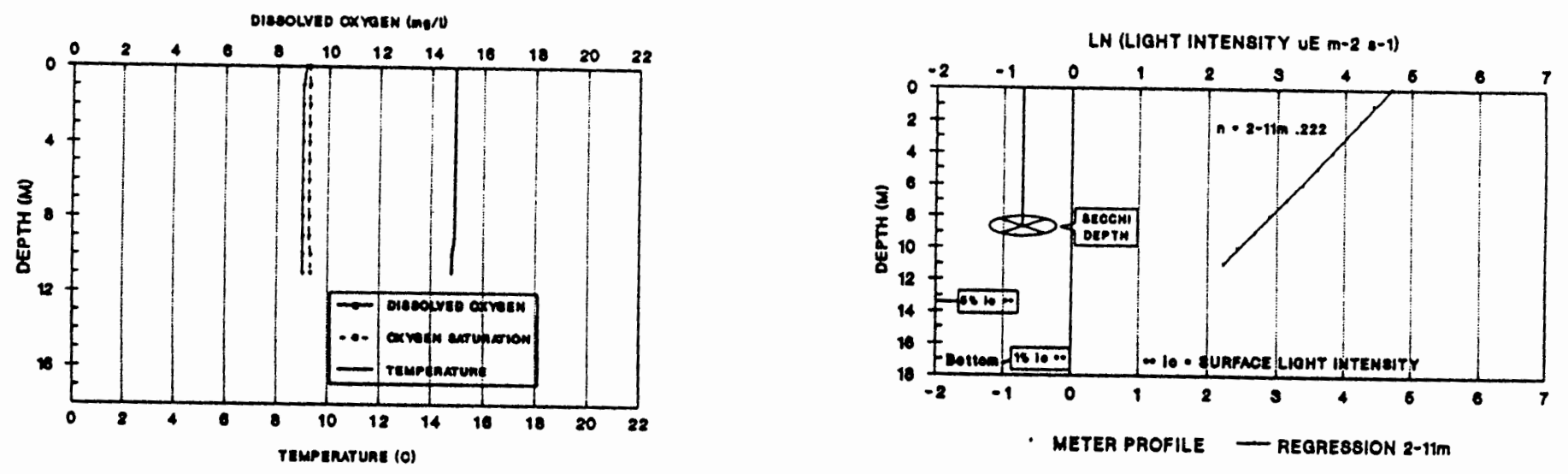
SUMMARY 


\section{Nutrient Concentrations as Determinants of Growth}

The relationship between the concentrations of DIN or SRP and chlorophyll-a in these lakes suggest that chlorophyll-a concentrations were somewhat dependent upon concentrations of the presumed limiting nutrient present during periods of thermal stratification. Although nutrient concentrations influence pigment production and growth, other factors such as light availability or differences between species can influence chlorophyll-a production in lakes.

Comparisons were made between concentrations of chlorophyll-a and either DIN or SRP, depending upon what nutrient was believed to limit the growth of the plankton. This analysis used the depth where the minimum nutrient concentration or maximum chlorophyll-a concentration was found. This approach assumed that the phytoplankton community was depleting the available nutrients at this depth to limiting concentrations. These minimum concentrations of nutrients do not necessarily reflect the total amount of nutrient that was assimilated. Future measurements of $\mathrm{N}$ or $\mathrm{P}$ uptake through the growing season should provide a more accurate relationship between nutrient concentrations chlorophyll-a production. 
DIN and Chlorophyll-a Concentrations

During periods of

thermal stratification,

concentrations of available $\mathrm{N}$

were reasonable indicators of

phytoplankton biomass in

lakes classified as $\mathrm{N}$ limited.

A positive relationship was

found between concentrations

of DIN and chlorophyll-a

(Figure 59). A linear

regression for this data

produced an $\mathbf{R}$ squared of

Chlorophyll-a Concentrations

Functions of DIN in N Limited Lakes

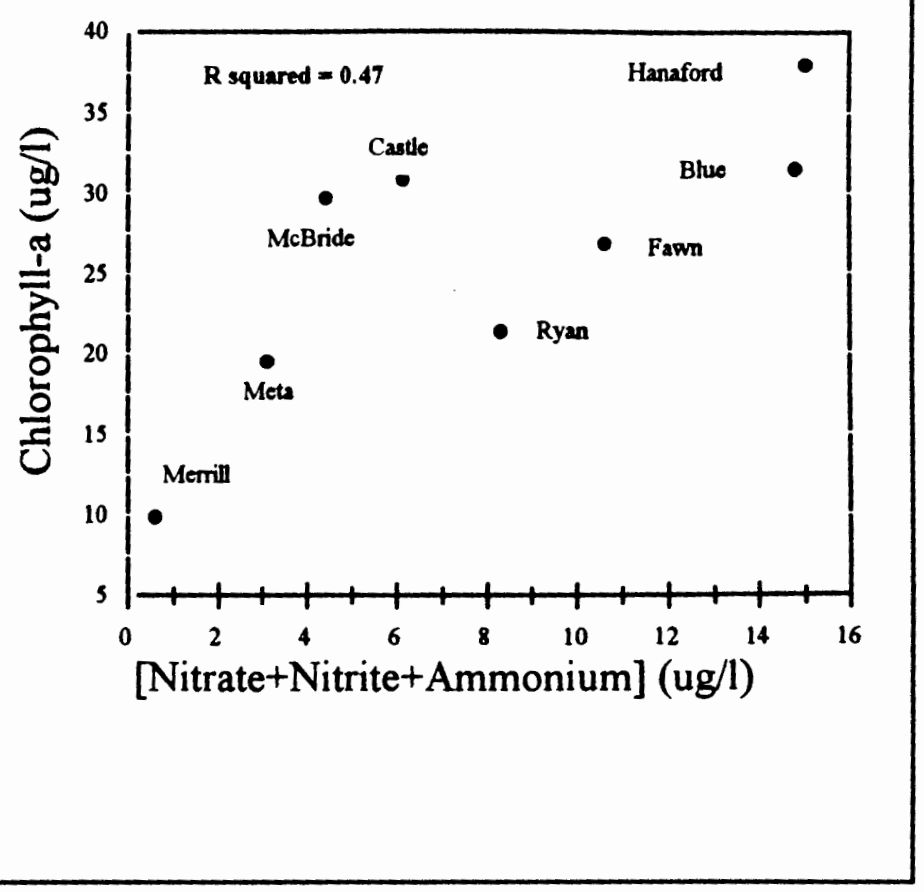

Figure 59

0.47 . The data suggest that in

the $\mathrm{N}$ limited lakes less chlorophyll-a will be present when lesser amounts of $\mathrm{N}$ are

available. Differences between the plankton composition and abundance, morphology,

and location relative to the volcano make it difficult to draw strong conclusions from these data. 
SRP and Chlorophyll-a Concentrations

A scatter plot of SRP concentrations and chlorophyll-a from lakes considered to be P limited produced two distinct groupings, each having a different slope (Figure 60). A linear regression using Panhandle, Venus, St. Helens, and Hanaford Lakes produced an R squared of 0.77 . These lakes appear to make more chlorophyll-a relative to $P$ supply than the other $P$ limited lakes in this study. These lakes are relatively more transparent than the others (in 1993 they had the four lowest extinction coefficients of all the lakes).

One possibility for the higher concentration of chlorophyll$a$ in these lakes is that the plankton communities may be dominated by phytoplankton, rather than bacteria, although further information would be necessary to confirm this.

\section{Chlorophyll-a Concentrations} Functions of SRP in $P$ Limited Lakes

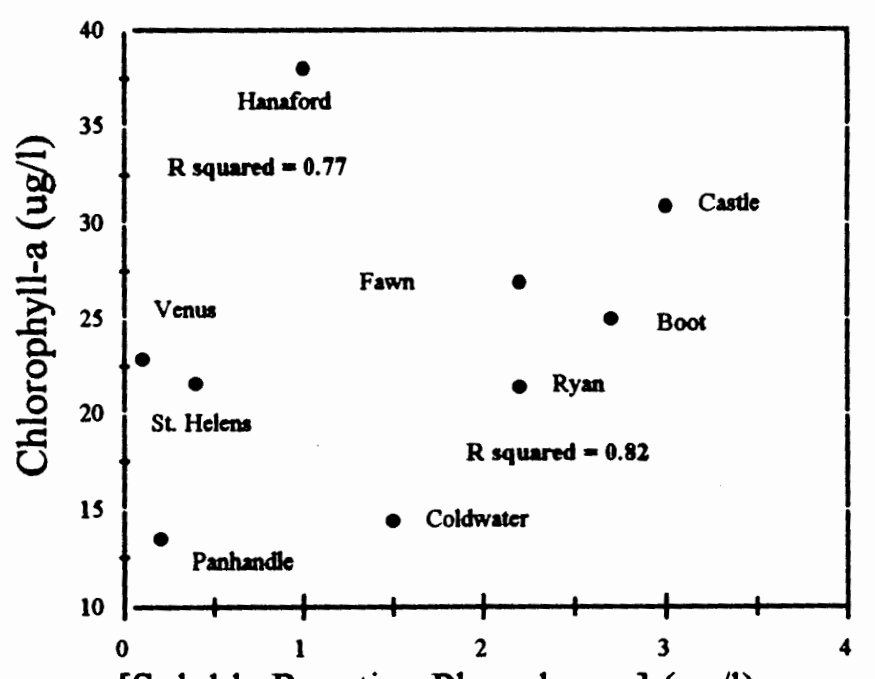

[Soluble Reactive Phosphorus] (ug/l)

The other group of lakes (Fawn, Ryan, Boot, and the newly formed Castle and Coldwater Lakes; $R$ squared $=0.82$ ) received more organic material from the eruption which resulted in higher concentrations of both DOC and total numbers of bacteria (Table 40). 
The four highest concentrations of both DOC and total bacteria following the 1980 eruption were found in these lakes (Table 40; Wissmar et. al. 1982 b). In 1993, these lakes had considerably higher extinction coefficients (almost three times higher) than lakes in the first group (Table 41). It is possible that higher concentrations of bacteria relative to phytoplankton in some of these lakes would result in lower chlorophyll-a concentrations for a given concentration of SRP. Bacteria have lower affinities for SRP than phytoplankton and are therefore better competitors for this resource (Currie and Kalff 1984). Again, data on bacterial activity is lacking and would be needed to confirm these hypotheses. 
Table 40. Dissolved chemical characteristics (Millipore filterable, $0.45 \mu \mathrm{m}$ ) and physical features of lakes near Mount St. Helens. Samples were taken $0.25 \mathrm{~m}$ below the surface on June 30, 1980. ND, no data. Data from Wissmar et al. (1982 a,b).

\begin{tabular}{|c|c|c|c|c|c|c|c|c|c|c|c|c|c|c|}
\hline & & & Lakes & Inside & Blast & Zone & & & Newly & Formed & Lakes & Outside & Blast & Zone \\
\hline Characteristic & Boot & Fawn & Hanaford & Meta & Panhandle & Ryan & St. Helens & Venus & Coldwater & Castle & Blue & June & McBride & Merrill \\
\hline Maximum depth (m) & 14.5 & 18 & 16 & 8 & 18 & 7 & $>90$ & 39 & 62 & 32 & 30 & 1.5 & 2 & 18 \\
\hline Elevation (m) & 1415 & 1200 & 1260 & 1097 & 1415 & 1018 & 1405 & 1415 & 740 & 740 & 1200 & 985 & 862 & 474 \\
\hline Distance from crater $(\mathrm{km})$ & 15 & 15 & 14 & 13 & 16 & 19 & 10 & 16 & 11 & 5 & 28 & 6 & 9 & 126 \\
\hline Alkalinity $(\mu \times q)$ ) & 195 & 367 & 461 & ND & 99 & 409 & 110 & 24 & 1520 & 4500 & 136 & 563 & 146 & 126 \\
\hline$D O C(m g /)$ & 4.98 & 1.34 & 4.79 & ND & 3.6 & 10.97 & 2.42 & 1.91 & 23.14 & 148.65 & 0.65 & 2.28 & 1.29 & 1.09 \\
\hline $\mathrm{pH}$ & 6.91 & 6.82 & 6.97 & ND & 7.42 & 6.71 & 7.11 & 7.07 & 6.61 & 6.17 & 6.95 & 6.73 & 7.46 & 7.2 \\
\hline Soluble reactiveP $(\mu g /)$ & 4.0 & 0.9 & 2.2 & ND & 3.7 & 5.0 & 2.8 & 2.5 & 2.2 & 13.9 & 1.8 & 31 & 1.2 & 1.8 \\
\hline Inorganio $N(\mu g /)$ & 7.0 & 51.9 & 5.7 & ND & 4.9 & 11.2 & 4.2 & 5.6 & 14.7 & 115.6 & 4.6 & 60 & 5.0 & 3.8 \\
\hline DIN:SRP & 1.7 & 56 & 2.6 & ND & 1.3 & 2.3 & 1.5 & 2.3 & 6.8 & 8.3 & 2.5 & 1.9 & 4.1 & 2.0 \\
\hline Silicon (mg/) & 5.0 & 5.8 & 5.5 & ND & 4.1 & 7.0 & 4.1 & 3.0 & 8.0 & 17.5 & 3.9 & 15.7 & 5.5 & 3.5 \\
\hline Light extinction $\left(m^{-1}\right)$ & 14.3 & 3.04 & 4.28 & ND & 16.38 & 7.82 & ND & 3.75 & 7.21 & 12.43 & 0.71 & ND & 0.59 & 0.56 \\
\hline Total bacteria per ml & $3 \times 10^{5}$ & $2 \times 10^{6}$ & $2 \times 10^{6}$ & ND & $7 \times 10^{5}$ & $1 \times 10^{7}$ & $1 \times 10^{6}$ & $7 \times 10^{5}$ & $7 \times 10^{6}$ & $2 \times 10^{7}$ & $8 \times 10^{5}$ & $1 \times 10^{5}$ & $6 \times 10^{5}$ & $5 \times 10^{5}$ \\
\hline Chiorophyll-a $(\mu g /)$ & 0.0 & 0.3 & 0.1 & ND & 0.0 & 0.0 & 0.0 & 0.7 & 0.0 & 0.6 & 0.6 & 0.1 & 1.3 & 0.3 \\
\hline
\end{tabular}


Table 41. Dissolved chemical characteristics (Millipore filterable, $0.45 \mu \mathrm{m}$ ) and light extinction coefficients of lakes near Mount St. Helens. Samples were taken $1.0 \mathrm{~m}$ below the surface during the peak of temperature stratification, 1993. ND, no data.

\begin{tabular}{|c|c|c|c|c|c|c|c|c|c|c|c|c|c|c|}
\hline & & & Lakes & Inside & Blast & Zone & & & Newly & Formed & Lakes & Outside & Blast & Zone \\
\hline Characteristic & Boot & Fawn & Hanaford & Meta & Panhandle & Ryan & St. Helens & Venus & Coldwater & Castle & Blue & June & McBride & Merrill \\
\hline Light Extinction $\left(\mathrm{m}^{-1}\right)$ & 0.39 & 0.38 & 0.23 & 0.50 & 0.21 & 0.71 & 0.12 & 0.13 & 0.34 & 0.31 & ND & 0.24 & 0.94 & 0.29 \\
\hline Secchi disk depth (m) & 7.9 & 6.8 & 13.6 & 4.8 & 11.2 & 4.0 & 18.3 & 16.5 & 7.2 & 7.9 & 12.8 & bottom & 1.6 & 8.2 \\
\hline Alkalinity $(\mu \mathrm{eq} / \mathrm{h})$ & 91 & 350 & 187 & 347 & 55 & 271 & 150 & 78 & 313 & 449 & ND & 683 & 413 & 213 \\
\hline $\begin{array}{l}\text { Oxygen minimum } \\
(\mathrm{mg} / \mathrm{l})\end{array}$ & 8.5 & 1.0 & 5.3 & 0.3 & 5.7 & 1.4 & 3.5 & 3.6 & 4.2 & 0.3 & 0.8 & 10.8 & 8.5 & 5.4 \\
\hline $\begin{array}{l}\text { Soluble Reactive P } \\
(\mu g / 1)\end{array}$ & 0.9 & 0.8 & 1.0 & 2.3 & 0.2 & 2.2 & 3.7 & 0.1 & 1.5 & 3.0 & 6.0 & 51.0 & 4.0 & 1.9 \\
\hline Inorganic $N(\mu \mathrm{g} /)$ & 62.2 & 13.5 & 15.0 & 3.1 & 120 & 8.3 & 174.7 & 26.5 & 67.2 & 6.1 & 12.7 & 47.9 & 13.6 & 0.6 \\
\hline DIN:SRP & 69.1 & 16.9 & 15.0 & 1.3 & 600 & 3.8 & 47.2 & 265 & 44.8 & 2.0 & 2.1 & 0.9 & 3.4 & 0.32 \\
\hline Silicon (mg/) & 6.6 & 6.7 & 6.0 & 8.3 & 6.0 & 9.2 & 5.7 & 4.6 & 9.0 & 9.8 & 5.7 & $>24.0$ & 8.8 & 6.4 \\
\hline Chlorophyll-a $(\mu \mathrm{g} /)$ & 11 & 8.3 & 38 & 19.5 & 13.5 & 21.4 & 39.9 & 22.9 & 60.4 & 30.9 & 15.8 & 28 & 13.4 & 9.9 \\
\hline
\end{tabular}




\section{Nutrient Ratios and Limitation}

Evaluations using ratios of available nutrients were consistent with conclusions drawn from bioassays, nutrient concentrations, and depletion of nutrient pools (see Table 42). Most of the lakes in this report could be grouped into two categories using the

Table 42. Comparison of different approaches to nutrient limitation and light data from lakes near Mt. St. Helens, WA. N = nitrogen limited, $\mathrm{P}=$ phosphorus limited NP = limited by both nitrogen and phosphorus

\begin{tabular}{|l|c|c|c|c|c|}
\hline \multicolumn{1}{|c|}{ Lake } & $\begin{array}{c}\text { DIN:SRP } \\
\text { Ratios }\end{array}$ & $\begin{array}{c}\text { Depletion of } \\
\text { Nutrient } \\
\text { Pool }\end{array}$ & $\begin{array}{c}\text { Enrichment } \\
\text { Experiments }\end{array}$ & $\begin{array}{c}\text { Alkaline } \\
\text { Phosphatase } \\
(\% \text { blanks })\end{array}$ & $\begin{array}{c}\text { Extinction } \\
\text { Coefficient } \\
\left(\mathrm{m}^{-1}\right)\end{array}$ \\
\hline Merrill * & 0.3 & $\mathrm{NP}$ & & 22 & 0.29 \\
\hline McBride * & 0.8 & $\mathrm{~N}$ & & 18 & 0.94 \\
\hline Meta & 1.4 & $\mathrm{~N}$ & & 43 & 0.50 \\
\hline Castle & 2.1 & $\mathrm{NP}$ & $\mathrm{NP}$ & & 0.31 \\
\hline Blue * & 2.5 & $\mathrm{~N}$ & & & \\
\hline Ryan & 3.7 & $\mathrm{NP}$ & $\mathrm{NP}$ & 123 & 0.71 \\
\hline Fawn & 4.6 & $\mathrm{NP}$ & $\mathrm{NP}$ & 113 & 0.38 \\
\hline REDFIELD & 7.2 & & & & \\
\hline Hanaford & 15.4 & $\mathrm{P}$ & $\mathrm{NP}$ & 68 & 0.23 \\
\hline Coldwater & 51.8 & $\mathrm{P}$ & & 42 & 0.34 \\
\hline Boot & 69.6 & $\mathrm{P}$ & & & 0.39 \\
\hline St. Helens & 356 & $\mathrm{P}$ & & & 0.12 \\
\hline Venus & 430 & $\mathrm{P}$ & $\mathrm{P}$ & & 0.13 \\
\hline Panhandle & 1208 & $\mathrm{P}$ & & 134 & 0.12 \\
\hline
\end{tabular}

* Control Lakes 
DIN:SRP ratios and bioassay data. Meta, McBride, Ryan, Fawn, Castle, Blue, and Merrill Lakes had DIN:SRP ratios below the Redfield ratio, indicating $\mathrm{N}$ limitation. Lakes which had DIN:SRP ratios above the Redfield ratio, thus indicating P limitation, were Hanaford, Coldwater, Boot, St. Helens, Venus, and Panhandle Lakes. In this evaluation, Ryan, Castle, Fawn, and Hanaford Lakes were positioned in the transition area between limitation by $\mathbf{N}$ and $\mathrm{P}$ and bioassay experiments provided similar evidence for colimitation by $\mathrm{N}$ and $\mathrm{P}$ in these lakes.

\section{The Relationship Between Nutrient Uptake and Nutrient Ratios}

The degree of nutrient

limitation as determined by

DNN:SRP ratios was related to the percentage of $\mathrm{N}$ or $\mathrm{P}$ assimilated by the plankton during the growing season (Figures 61 and 62). For these analyses, the uptake was estimated from nutrient concentrations during isothermal and stratified conditions. When seasonal

\section{DIN Uptake for All Lakes}

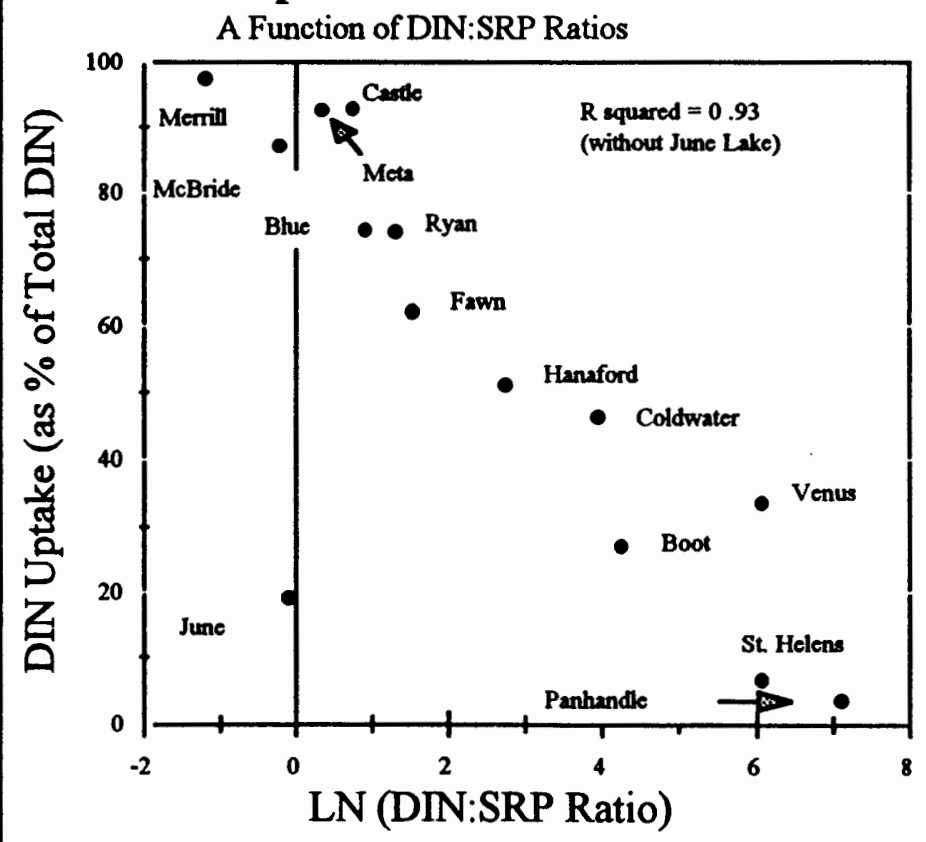


data were not available, hypolimnia concentrations were used. Lakes which had increasingly lower DIN:SRP ratios were characterized as assimilating a higher proportion of the available N. For example, during stratification, Merrill, Meta, McBride, and Castle Lakes were severely $\mathrm{N}$ limited (low N:P ratios) and therefore depleted a higher percentage of the DIN. Lakes having a N:P ratio below the Redfield value (7.2) assimilated over $60 \%$ of the available supply. Lakes having increasingly larger N:P ratios (becoming increasingly $\mathrm{P}$ limited) assimilated even less $\mathrm{N}$. A linear regression using this data (with the exception of June Lake which because of abundant $\mathrm{N}$ and $\mathrm{P}$ was probably not nutrient limited) produced a strong positive relationship $(\mathrm{R}$ squared $=0.93)$.

A similar but less distinct relationship was found for those lakes limited by $\mathrm{P}$ (Figure 62).

Lakes having increasingly higher DIN:SRP ratios (increasing in $P$ limitation) assimilated a higher proportion of available SRP. The lakes which had demonstrated severe $\mathrm{N}$ limitation assimilated the least SRP (Usually less than $40 \%$ of available SRP). Fawn and Hanaford Lakes had DIN:SRP

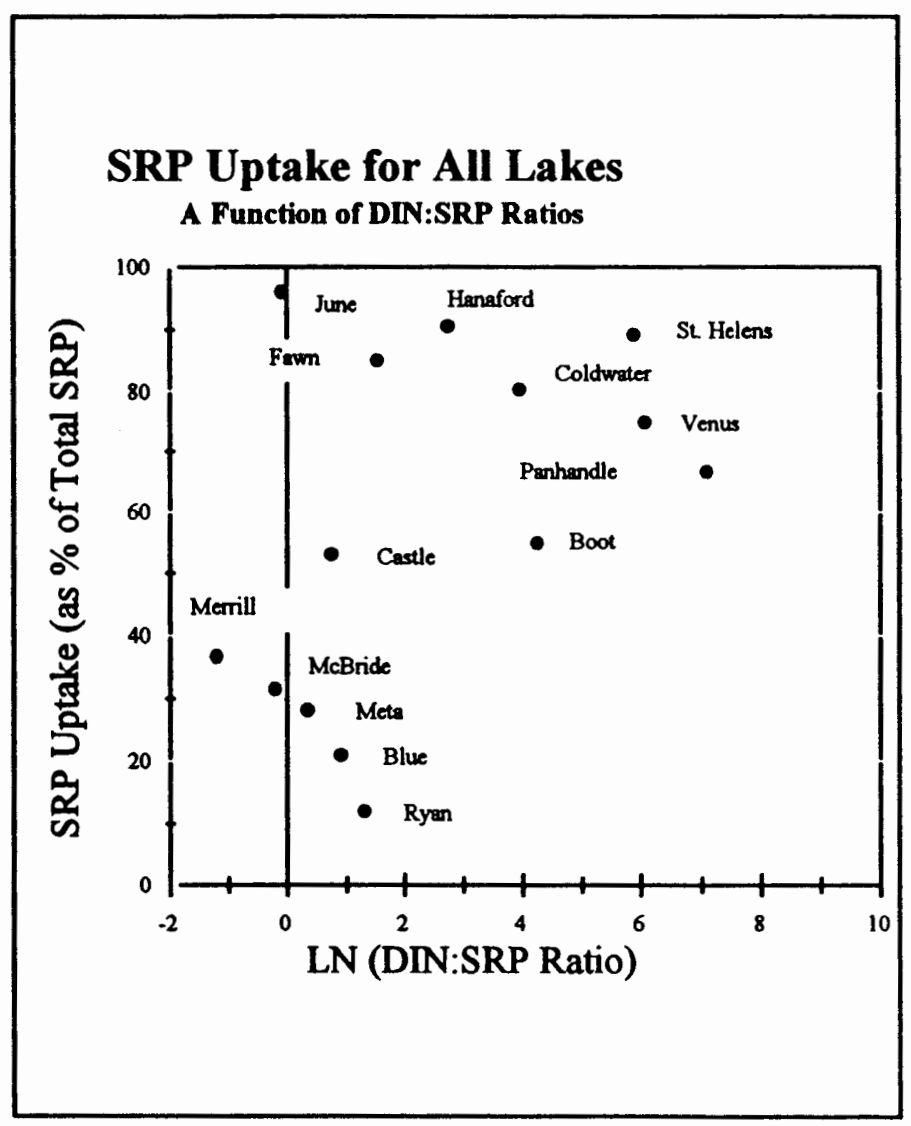

Figure 62 ratios near the Redfield value, yet 
depleted nearly $90 \%$ of available SRP. Such would be the case if these lakes were colimited by $\mathrm{N}$ and $\mathrm{P}$. Bioassay data from these lakes confirms this hypothesis. The relationship between nutrient ratios and percentage of nutrient assimilation is not as clear for $\mathbf{P}$ as it was for $\mathbf{N}$. Analytical measurements of phosphorus (SRP) may overestimate $\mathbf{P}$ availability, while short turnover times or the presence of phosphatases could increase $P$ availability for the plankton.

\section{Alkaline Phosphatase Activity as an Indicator of Nutrient Deficiency}

Activities of the cell

surface enzyme alkaline

phosphatase revealed an

inverse relationship ( $R$

squared $=0.26$ ) between

enzyme activity and

concentrations of SRP (see

Figure 63). During periods of

limited SRP availability,

plankton cells may express

and activate phosphatase

enzymes to liberate SRP from
Alkaline Phosphatase Activity

A Function of SRP Concentration

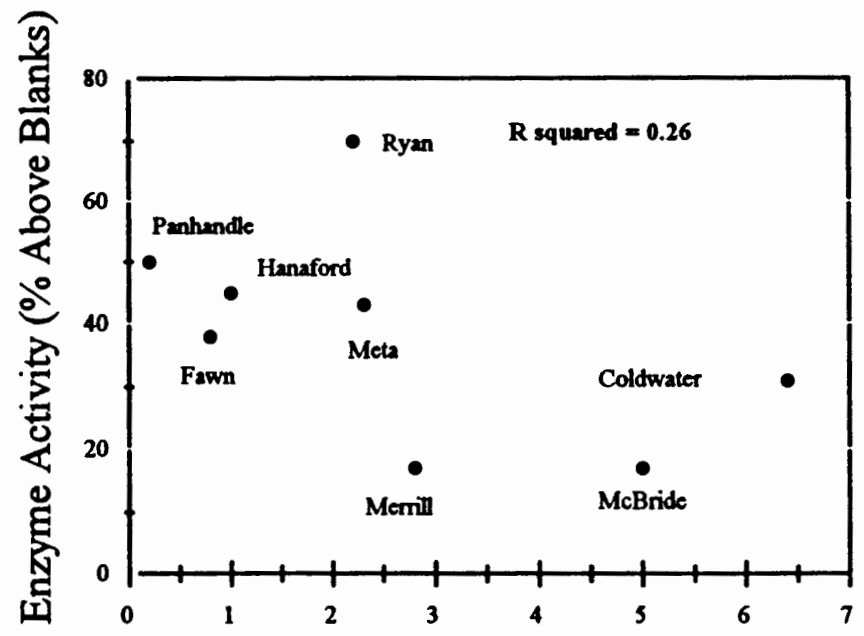

[Soluble Reactive Phosphorus] (ug/l) 
unavailable forms of $\mathrm{P}$ such as polyphosphate. In general, the APA decreased as the concentration of SRP increased. Differences between lakes can be explained in part by phytoplankton abundances. For example, Hanaford and Meta Lakes had higher APAs than Fawn Lake, even though Fawn Lake had less SRP. The chlorophyll-a concentrations in Hanaford and Meta Lake were almost twice that for Fawn Lake (see Table 43). In general APA appears to increase when SRP concentrations fall somewhere below $5 \mu \mathrm{g} /$. This is consistent with Reynolds (1984) who suggested that phytoplankton growth will not be limited by $P$ when concentrations are between 5 and $10 \mu \mathrm{g} /$. One lake not included in Figure 63 is June Lake, which had the lowest APA of all the lakes ( $16 \%$ over controls) and the highest SRP concentration $(49 \mu \mathrm{g} /)$.

Table 43. Alkaline phosphatase activity and concentrations of SRP and chlorophyll-a in Mount St. Helens lakes, 1993.

\begin{tabular}{|l|c|c|c|}
\hline \multicolumn{1}{|c|}{ Lake } & $\begin{array}{c}\text { APA } \\
(\% \text { over controls })\end{array}$ & $\begin{array}{c}\text { SRP } \\
(\mu \mathrm{g} /)\end{array}$ & $\begin{array}{c}\text { Chlorophyll-a } \\
(\mu \mathrm{g} /)\end{array}$ \\
\hline Ryan & 70 & 2.2 & 17.7 \\
\hline Hanaford & 45 & 1 & 20.5 \\
\hline Meta & 43 & 2.3 & 31.1 \\
\hline Fawn & 38 & 0.8 & 10.5 \\
\hline Coldwater & 31 & 6.4 & 23.0 \\
\hline Panhandle & 25 & 0.2 & 11.6 \\
\hline Merrill & 17 & 2.8 & 24 \\
\hline McBride & 17 & 5 & 29.7 \\
\hline June & 16 & 49 & 11.2 \\
\hline
\end{tabular}


Normalizing the data to chlorophyll-a improves the relationship slightly but more importantly, produced a pattern which suggests a relationship between APA and the degree of organic loading from the enuption. Figure 64 shows that Fawn, Ryan, and Coldwater Lakes had higher APAs than the other lakes. These lakes also contained higher concentrations of DOC

\section{Alkaline Phosphatase Activity}

A Function of SRP Concentration

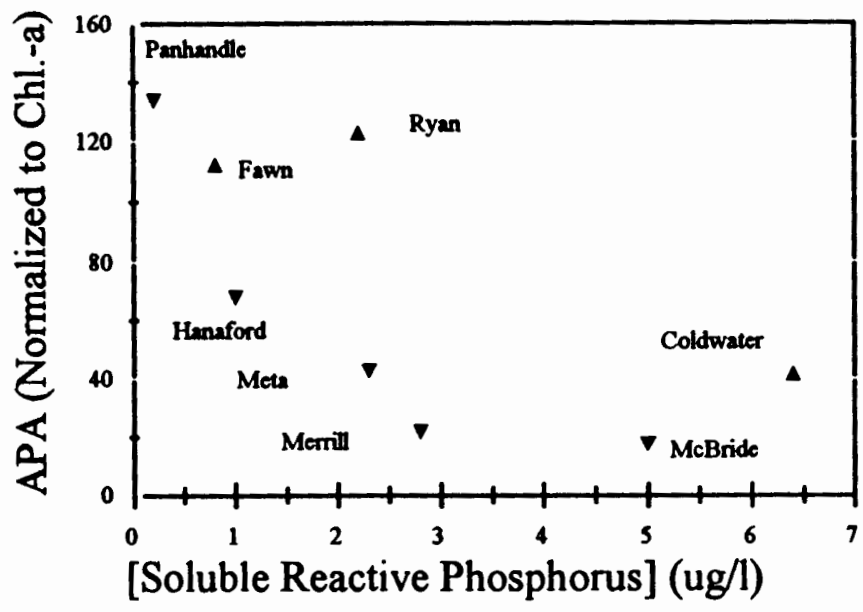

7 Lower 1980 DOC and bacteria

$\triangle$ Higher 1980 DOC and bacteria

Figure 64 and total numbers of bacteria following the eruption compared to the others (Wissmar et al. 1982 a,b). An exponential fit through the lakes having smaller DOC and bacterial concentrations after the eruption (Panhandle, Hanaford, Meta, Merrill and McBride Lakes) produced an $R$ squared of 0.98 , while an $R$ squared of 0.66 was obtained using Fawn, Ryan, and Coldwater Lakes. Because bacteria are capable of alkaline phosphatase production, these data suggest that the more impacted lakes continue to have significant bacterial communities, although actual bacterial counts were not made. Since plankton communities can have both bacteria and phytoplankton, normalizing APA with non-biased measures of biomass, such as ATP, would have been more appropriate. 
The evaluation of APA during nutrient addition experiments showed that APA could be suppressed with SRP additions, as expected (see Figures 10 and 21). When SRP concentrations were no longer limiting, energy could be directed into other assimilates and the APA decreased. Further, APA could be increased with ammonium additions. Additions of $\mathbf{N}$ stimulated $\mathbf{P}$ demand and the cells responded by producing alkaline phosphatase (see Figure 10).

The use of alkaline phosphatase as an indicator of $\mathrm{P}$ deficiency is recommended because this assay is inexpensive and can be performed in the field. The precision is acceptable (average increase in activity was 38.0\%, SD 4.0). Although GF/F filters were used during this study, it is recommended that $0.45 \mu \mathrm{m}$ cellulose nitrate filters be used because these filters do not release particulates into the solution during incubation. Although incubation times for this study were 4 hours, longer incubations may be desired, particularly if plankton abundances are low. 
CONCLUSION 


\section{Evaluations of Nutrient Limitation}

Conclusions regarding nutrient deficiency drawn from nutrient concentrations and ratios coincided reasonable well. The depletion of nitrogen, phosphorous, or both from the surface waters provided the best evidence for both nutrient uptake and degree of limitation. Nutrient ratios corresponded well with the proportion of limiting nutrient depleted during the growing season. Results from nutrient enrichment experiments confirmed the presence of dual limitation by both $\mathrm{N}$ and $\mathrm{P}$ in four of the lakes (Ryan, Fawn, Hanaford, and Castle). Decreases in the concentrations of non-limiting nutrients following additions of limiting nutrients often confirmed the presence of nutrient limitation. Separate measures of growth (carbon fixation and chlorophyll-a production) often produced different responses to nutrient enrichment.

Although sufficient data are lacking to confirm the presence of significant bacterial populations in these lakes, some evidence suggests this may be the case. Patterns of increased plankton growth with nutrient addition suggest that the plankton communities in some of the lakes are composed of both an autotrophic (algal) and heterotrophic (bacterial) component. Phosphorous additions often stimulated chlorophyll-a production, while ammonium-N usually increased carbon fixation (e.g. Ryan and Fawn Lakes). It is suggested that $\mathrm{N}$ additions stimulated ammonium oxidizing bacteria in the lakes while $\mathrm{P}$ stimulated the phytoplankton community. Further, many of these lakes have increased light attenuation in the deeper waters. Although a definitive source of this has not been identified, it is possible that elevated concentrations of DOC from the eruption remain in 
these lakes which might support bacterial communities.

Alkaline phosphatase (AP) activities were good indicators of phosphorous deficiency and produced an inverse relationship with concentrations of $P$. Further, AP activities could be increased or decreased with nutrient respective additions of $\mathrm{N}$ or $\mathrm{P}$. Chlorophyll-a normalized APA provides indirect evidence for elevated bacterial phosphatase activities in some of the heavily impacted lakes 


\section{The Return to Pre-Eruption Conditions}

The effects of the May 18, 1980 eruption of Mount St. Helens on the ecology of the lakes in the blast zone were monumental. Tremendous amounts of organic material from the surrounding watersheds converted the once pristine lakes from ultraoligotrophic. to hypereutrophic in a few months. Because of the low N:P ratio of the coniferous material which was deposited in the lakes, nitrogen cycling by the invading bacterial community was prolific. The decomposition of organic material depleted dissolved oxygen concentrations and anaerobic conditions were produced. Water transparency and phytoplankton community data from these lakes indicate that the return to pre-eruption conditions is well under way. Populations of amphibians and fish in some of the lakes confirm this conclusion. Oxygen depletion in the hypolimnia of these lakes, however, suggests that organic material near the bottom continues to be metabolized by the bacterial community. The rate of decomposition of this material may depend on the oxygenation of the water during periods of turnover. Because some of the lakes are deep and somewhat protected, circulation may not be completed each year during turnover as suggested by elevated conductivity values in bottom waters in some of the lakes. These factors may interact to retard the aerobic breakdown of this organic material. Full return of these lakes to the pristine lakes that they once were will depend upon future rates of autochthonous production of organic material by the resident plankton communities and the processing of the material from the 1980 eruption. 


\section{LITERATURE CITED}

Ameel, J.J., R.P. Axler, and C.J. Owen. 1993. Persulfate digestion for determination of total nitrogen and phosphorous in low-nutrient waters. Am. Environ. Lab. October 1993.

Baker, Cyndi. 1995. Phytoplankton Communities in Mount Saint Helens Lakes. MS Thesis, Portland State Univ., in prep.

Baross, J.A., C.N. Dahm, A.K. Ward, M.D. Lilley, and J.R. Sedell. 1982. Initial microbial responses in lakes to the Mt. St. Helens eruption. Nature. 296: 49-52.

Boni, L., E. Carpene, D. Wynne, and M. Reti. 1989. Alkaline phosphatase activity in Protogonyaulax tamarensis. J. Plankton Res. 11: 879-885.

Cole, G.A. 1983. Textbook of Limnology, 3rd. ed., Waveland Press, Inc. 401 pp.

Currie, D.J. and J. Kalff. 1984. A comparison of the abilities of freshwater algae and bacteria to aquire and retain phosphorus. Limnol. Oceanog. 292 (2): 298-310.

Daggett, S.G. 1994. Evidence for the eutrophication of selected coastal dunal lakes: historical comparison of indices for nutrient enrichment. MS thesis, Portland State Univ. $140 \mathrm{pp}$.

Dahm, C.N., J.A. Baross, A.K. Ward, M.D. Lilley, R.C. Wissmar, and A.H. Devol . 1981. Final report North Coldwater Lake and vicinity: limnology, chemistry, and microbiology.

Dahm, C.N., J.A. Baross, A.K. Ward, M.D. Lilley, J.R. Sedell . 1983. Initial effects of the Mount St. Helens eruption on nitrogen cycles and related chemical processes in Ryan Lake. Appl.Environ. Microbiol. 45: 1633-1645.

Dion, N.P. and S.S. Embry. 1981. Effects of Mt. St. Helens eruption on selected lakes in Washington. U.S. Geological Survey Circular 850-G, 25 pgs.

Dodds, W.K. and J.C. Priscu. 1991. Ammonium stimulation of dark carbon fixation as an indicator of nitrogen deficiency in phytoplankton: potential errors caused by ammonium-oxidizing bacteria. J. Phycol 27: 79-82.

Dodds, W.K., J.C. Priscu., and B.K. Ellis. 1991. Seasonal uptake and regeneration of inorganic nitrogen and phosphorous in a large oligotrophic lake: size fractionation and antibiotic treatment. J Plankton Res. 13: 1339-1358. 
Dodds, W.K. and J.C. Priscu. 1990. A comparison of methods for assessment of nutrient deficiency of phytoplankton in a large oligotrophhic lake. Can J. Fish Aquat. Sci. 47:2328-2338.

Downing, J.A. and E. McCauley. 1992. The nitrogen:phosphorous relationship in lakes. Limnol.Oceanog. 37: 936-945.

Elser, J.J., E.R. Marzolf, and C.R. Goldman. 1990. Phosphorous and nitrogen limitation of phytoplankton growth in the freshwaters of North America: A review and critique of experimental enrichments. Can. J. Fish. Aquat. Sci. 47: 1468-1477.

Groeger, A.W. and B.L. Kimmel. 1988. Photosynthetic carbon metabolism by phytoplankton in a nitrogen-limited reservoir. Can J. Fish Aquat. Sci. 45: 720-730.

Hecky, R.E. and P. Kilham. 1988. Nutrient limitation of phytoplankton in freshwater and marine environments: A review of recent evidence on the effects of enrichment. Limnol. Oceanog. 33: 796-822.

Hooper, P.R., I.W. Herrick, E.R. Laskowski, and C.R. Knowles. 1980. Mount St. Helens ash from the 18 May 1980 eruption: chemical, physical, mineralogical, and biological properties. Science 209: 1116-1126. 1980

Howarth, R.W. and J.J. Cole. 1985. Molybdenum availability, nitrogen limitation, and phytoplankton growth in natural waters. Science 229: 653-655.

Jones, M.N. 1984. Nitrate reduction by shaking with cadmium, alternative to cadmium columns. Water Res. 18: 643-646.

Kelly, V.J. 1992. Limnology of two new lakes Mount St. Helens, WA. MS Thesis, Portland State Univ. 173 pp.

Kilham, P. 1971. A hypothesis concerning silica and the freshwater planktonic diatoms. Limnol. Oceanog. 16: 10-18.

Levine, S.N. 1983. Natural mechanisms that ameliorate nitrogen shortages in lakes. Ph.D. thesis, Univ. Manitoba. 354 pp.

Liao, C.F.-H. and D.R.S. Lean. 1978. Nitrogen transformations within the trophogenic zone of lakes. J. Fish. Res. Board Can. 35: 1102-1108.

Mackereth, F.J.H. 1953. Phosphorous utilization by Asterionella formosa. Hass. J. Exp. Bot. 4: 296-313. 
Petersen, R.P. 1975. The paradox of the plankton: an equilibrium hypothesis. The American Naturalist 109: 965

Petersen R.P. 1993. Recovery of lakes located in the balst zone of Mount St. Helens. Verh. Internat. Verein. Limnol. 25: 366-369.

Reynolds, C.S. 1984. The ecology of freshwater phytoplankton. Cambridge University Press. 384 pp.

Schindler, D.W. 1977. Evolution of phosphorous limitation in lakes. Science 195: 260262.

Smith, G.M. 1933. The freshwater algae of the United States, 2nd. ed. McGraw-Hill Book Co., Inc.

Sommer, U., Z.M. Gliwicz, W. Lampert, and A. Duncan. 1986. The PEG model of seasonal succession of planktonic events in fresh waters. Arch. Hydrobiol. 106: 433-471.

Sommer, U. 1987. Factors controlling the seasonal variation in phytoplankton species composition - a case study for a deeep, nutrient rich lake. Prog. Phycol. Res. 5: 124-178.

Tilman, D., S.S. Kilham, and P. Kilham. 1982. Phytoplankton community ecology: the role of limiting nutrients. Ann. Rev. Ecol. Syst. 13: 349-372.

Tilman, D., R. Kiesling, R. Sterner, S.S. Kilham, and F.A. Johnson. 1986. Green, bluegreen and diatom algae: Taxonomic differences in competitive ability for phosphorous, silicon, and nitrogen. Arch. Hydrobiol. 106: 473-485.

Vincent, W.F. 1981. Rapid physiological assays for nutrinet demand by the plankton. I. Nitrogen, II. Phosphorous. J. Plankton Res. 3: 685-709.

Ward, A.K., J.A. Baross, C.N. Dahm, M.D. Lilley, and J.R.Sedell. 1983. Qualitative and quantitative observations on aquatic algal communities and recolonization within the blast zone of Mt. St. Helens, 1980 and 1981. J. Phycol. 19: 238-247.

Wetzel, R.G. 1983. Limnology. Saunders College Publishing. 767 pp.

Wetzel R.G. and G.E. Likens. 1991. Limnological Analyses, 2nd. ed. Springer-Verlag, Inc. $391 \mathrm{pp}$. 
White, E. and G.W. Payne. 1977. Chlorophyll production, in response to nutrient additions, by the algae in lake Taupo water. N.Z. J. Mar. Fresh. Res. 11: 501-507.

Wissmar, R.C. 1982. Limnological features of lakes within the 18 May 1980 Mount St. Helens balst zone. Mount St. Helens: one year later. Eastern Washington University Press, Cheney, WA.

Wissmar, R.C., A.H. Devol, and A.E. Nevissi. 1982a. Chemical changes of lakes within the Mount St. Helens blast zone. Science 216: 175-178.

Wissmar, R.C., A.H. Devol, J.T. Staley, and J.R. Sedell. 1982b. Biological responses of lakes in the Mount St. Helens blast zone. Science 216: 178-180. 
APPENDIX A

METHODS FOR BIOASSAY EXPERIMENTS 


\section{BIOASSAY EXPERIMENTS}

\section{Long Term Enrichment}

Long term bioassay experiments were conducted on waters from Fawn, Hanaford, Ryan, Castle, and Venus lakes lake during summer stratification to determine the effect of nutrient enrichment. 20 liter polyethylene cubitainers (Van Waters and Rogers) were filled with lake water and incubated with and without nutrient additions at a depth of $4 \mathrm{~m}$ to simulate natural light and temperature conditions. Two cubitainers were used for each treatment: control (no addition), + nitrogen, + phosphorus, and + nitrogen $\&$ phosphorus. Cubitainers were sampled after 4-5 days to detect changes in rates of carbon fixation, chlorophyll a concentration, and/or nutrient concentrations.

Lake water was collected from a depth of $4 \mathrm{~m}$ with a displacement sampler (J.C.

Priscu personal communication) and dispensed into the cubitainers with a funnel. Nutrient additions were made to the cubitainers in the form of a concentrated aqueous solution of 5 $\mathrm{mM} \mathrm{NH}_{4} \mathrm{Cl}, 1 \mathrm{mM} \mathrm{KH}_{2} \mathrm{PO}_{4}$, or both. $5 \mathrm{mM} \mathrm{NH}_{4} \mathrm{Cl}$ was prepared by adding $271 \mathrm{mg}$ $\mathrm{NH}_{4} \mathrm{Cl}$ to 1 liter deionized water. Twenty $\mathrm{ml}$ of this solution increased $\mathrm{NH}_{4}-\mathrm{N}$ concentration inside the mesocosms $70 \mu \mathrm{g} \mathrm{N} / 1$. One $\mathrm{mM} \mathrm{KH}_{2} \mathrm{PO} 4$ was prepared by adding $133 \mathrm{mg} \mathrm{KH}_{2} \mathrm{PO}_{4}$ to 1 liter deionized water. Twenty $\mathrm{ml}$ of this solution increased $\mathrm{PO}_{4}-\mathrm{P}$ concentration inside the mesocosms $31 \mu \mathrm{g} \mathrm{P} / 1$.

Following incubation, cubitainers were retrieved, mixed well, and water samples were collected to measure alkaline phosphatase activity, carbon fixation rates and concentrations of chlorophyll and nutrients. 


\section{Alkaline Phosphatase}

Alkaline phosphatase activity was semi-quantitatively measured to detect phosphorus limitation. In the presence of this cell surface enzyme, P-nitrophenol phosphate (PNPP) is cleaved into PNP+Pi, and produces a yellow color. Absorbance was evaluated using spectrophotometry.

\section{$\underline{\text { Reagents }}$}

PNPP reaction mixture Add $2.422 \mathrm{~g}$ Trizma (Sigma Trizma $\otimes$ base) to $800 \mathrm{ml} 2 \mathrm{xH} 20$, adjusting the $\mathrm{pH}$ to 8.6 with concentrated $\mathrm{HCl} .0 .5262 \mathrm{~g}$ PNPP (Sigma®) 104-0, crystalline), $5.0825 \mathrm{~g} \mathrm{MgCl}_{2} \cdot 6 \mathrm{H}_{2} \mathrm{O}$ (Mallinckrodt@), and $50, \mu \mathrm{l}$ of chloroform (Mallinckrodt $\left(\right.$ ) is added to this solution, diluting to 1 liter with $2 \mathrm{xH}_{2} 0$. This produces a reaction mixture containing $2 \mathrm{mM}$ PNPP, $20 \mathrm{mM}$ Trizma, and $25 \mathrm{mM} \mathrm{Mg}^{++}$.

\section{Analytical Procedure}

Water samples were collected with a van Dorn sampler from a depth of $1 \mathrm{~m}$. Sample aliquots of $10 \mathrm{ml}$ were added to four $15 \mathrm{ml}$ polypropylene centrifuge tubes (Van Waters and Rogers $($ ). For each tube, $100 \mathrm{ml}$ of lakewater was filtered through a $47 \mathrm{~mm}$ Whatman GF/F filter using a Nalgene(8) hand pump filtration unit under minimal vacuum pressure. Filters were carefully rolled (with phytoplankton on the inside) and placed into each tube. The filters were placed below the surface of the water and $1 \mathrm{ml}$ of PNPP reaction mixture was added to each tube. The tubes were gently inverted three times. Triplicate experimental tubes were prepared for each lake and were compared to the 
control tube, which received the filter but no reaction mixture. Samples were incubated for a time period of at least 4 hours in the dark and solutions from the tubes were read at a of $410 \mathrm{~nm}$ using a portable field spectrophotometer (Bausch and Lomb Spectronic mini 20) having a path length of $1 \mathrm{~cm}$.

\section{Carbon Fixation}

Triplicate subsamples taken from each of the 201 bags were incubated with radiolabelled $\mathrm{NaH}_{2}{ }^{14} \mathrm{CO}_{3}$ for $2 \mathrm{~h}$ at lake temperature. Prior to incubation, care was taken to minimize light exposure to the samples during processing. A black plastic tent was assembled to provide a dark shelter.

Aliquots of approximately $38 \mathrm{ml}$ were dispensed from the collection bottle into 40 ml Oakridge $\otimes$ tubes. Volumes were standardized by tipping the tubes on a plastic ramp which was fixed in a level position. Productivity standards were prepared by adding 250 $\mu$ l of Carbotrap (J.T. Baker) to six $20 \mathrm{ml}$ scintillation vials prior to ${ }^{14} \mathrm{C}$ addition. The ${ }^{14} \mathrm{C}$ inoculum was prepared by diluting $5 \mathrm{mCi}(2.5 \mathrm{ml}) \mathrm{NaH}_{2}{ }^{14} \mathrm{CO}_{3}, \mathrm{pH} 9.1$ (Amersham Corp.), to one liter in a buffered solution. The buffer was prepared by adding $\mathrm{NaOH}$ to $2 \mathrm{xH}_{2} 0$, $\mathrm{pH}$ 9.4. This produces a buffered ${ }^{14} \mathrm{C}$ inoculum with an activity of $5 \mu \mathrm{Ci} / \mathrm{ml} .250 \mu \mathrm{l}$ of this inoculum were added to the first set of standards (first 3 vials), to each sample tube (in triplicate), and finally to the second set of standards (second 3 vials) to achieve a final activity of $1.25 \mu \mathrm{Ci}$ per tube. Additions of ${ }^{14} \mathrm{C}$ to the standards were made after carefully inserting the autopipette tip below the surface of the Carbotrap and quickly capping to prevent loss of isotope to the atmosphere. After the addition of the inoculum, the sample 
tubes were capped and gently inverted to thoroughly mix. Oakridge $₫$ tubes were placed inside double layered incubation bags made of black screening material. Sample tubes were placed into the bags and were sheltered from sunlight with three layers of black plastic until reaching the incubation area. Incubations were carried out in the shoal area of the lake (< one foot depth) for two hours. The samples were taken out of the plastic bag at once and clothespinned to the top surface of a layer of black screening to minimize reflection from the shore sediments. The incubation bags were placed underwater in such a position as to maximize the sun's angle of incidence. Average light intensity was determined for the incubation period with a spherical LI-COR light sensor interfaced to a LI-COR-1000 data logger. This meter measures photosynthetically active radiation (PAR), in units of $\mu$ Einsteins $\mathrm{m}^{-2} \mathrm{~s}^{-1}$. The sensor was positioned just below the surface of the water adjacent to the light tubes.

Following incubation, tubes were placed into three dark plastic bags and transported to the dark hood. $10 \mathrm{~mL}$ aliquots were taken from each tube and transferred to numbered $20 \mathrm{ml}$ scintillation vials containing $250 \mu \mathrm{l}$ of $0.5 \mathrm{~N} \mathrm{HCl}$. Vials were returned to the lab and placed on a shaker (40 RPM) for twenty-four hours, with the caps off to allow unincorporated ${ }^{14} \mathrm{CO}_{3}$ to volatilize to the atmosphere. Nine $\mathrm{ml}$ of fluor scintillation fluid (SolventFree, Innovative Biochemical Methodology) were added to each scintillation vial prior to counting with a Beckman LS 6500 multi-purpose scintillation counter. This instrument reports counts in disintegrations per minute (DPM). 
APPENDIX B

METHODS FOR LABORATORY ANALYSIS 


\section{LABORATORY ANALYSIS}

\section{Chlorophyll-a}

Samples for chlorophyll-a were collected in detergent-cleaned $250 \mathrm{ml}$ dark HDPE Nalgene $\otimes$ sample bottles. During the processing of chlorophyll a samples, care was taken to avoid exposure to light. $100 \mathrm{ml}$ of sample and three drops of a saturated solution of $\mathrm{MgCO}_{3}$ were filtered through $47 \mathrm{~mm}$ Whatman $@ \mathrm{GF} / \mathrm{F}$ filters using a Nalgene® hand pump filtration unit. Filters were placed individually in petri slides, wrapped in foil and placed on ice in the dark until processing. A phaeophytin-corrected chlorophyll-a analysis was performed using the Oregon Department of Environmental Quality's procedure for the analysis of chlorophyll-a, outlined in Daggett (1994).

\section{Nutrient Analysis}

Nutrient analysis were performed to determine concentrations of nitrate+nitrite, ammonia, soluble reactive phosphorus (SRP), and silica. On some dates, analysis of total nitrogen and total phosphorus were made.

Replicate analyses were performed on samples and standards, treating them exactly the same. All reagents were prepared in volumetric flasks using reagent grade chemicals diluted with distilled water passed through a Barnstead® Nanopure II deionizer $\left(2 \mathrm{xH}_{2} 0\right)$. Reagents were stored in acid-washed polyethylene dark bottles, except where noted. Preparation of working standards was done individually, not using serial dilution, with calibrated micropipettes using acid-washed pipette tips. All glassware (and plasticware) 
were initially washed with phosphate free Micro® liquid detergent (1:100 dilution) before being rinsed 8 times $(8 \mathrm{x})$ with $2 \mathrm{xH}_{2} \mathrm{O}$. Routine washing consisted of rinsing all glassware $8 \mathrm{x}$ with $2 \mathrm{xH}_{2} 0$, followed by soaking in $4 \% \mathrm{HCl}$ for at least 12 hours. Prior to use, glassware was rinsed $8 \mathrm{x}$ with $2 \mathrm{xH}_{2} 0$. For each nutrient analysis, a colorimetric test was used, measuring absorbencies spectrophotometrically (Milton Roy® spectronic 401) with a 1 or $5 \mathrm{~cm}$ path length. The spectrophotometer was zeroed with $2 \mathrm{xH}_{2} 0$, and the reagent blanks read as samples. Absorbance values for reagent blanks were subtracted from all sample absorbance values. Lake waters were periodically evaluated to determine the absorbance of the water for a given nutrient test and wavelength. This can contribute a significant error in nutrient concentrations by giving false high values.

In performing nutrient analysis, great care must be exercised to prevent contamination. Careful storage and cleaning of all materials is essential. Nutrients (especially phosphates) carried in airborne dust particles can contaminate samples and reagents. Keeping glassware stored in a dilute acid bath $(4 \% \mathrm{HCl})$ and rinsing prior to use is recommended. Sources of contamination include phosphate containing detergents, lab paper towels, non-deionized water, and dirty hands. Due to the highly fragile nature of reagents used for the nutrient analysis, it is recommend that all reagents except the stock standards be prepared daily. Taking these precautions will increase precision. 
(Nitrate + Nitrite) - Nitrogen

\section{Reagents}

Nitrate standard stock solution Add $0.722 \mathrm{~g} \mathrm{KNO}_{3}$ oven dried $\left(105^{\circ} \mathrm{C}, 24 \mathrm{~h}\right)$, to a volumetric flask and dilute to 1 liter with $2 \mathrm{xH}_{2} 0$. This produces a $100,000 \mu \mathrm{g} \mathrm{N} /$ stock solution, which is diluted 1:100 to produce a working solution of $1,000 \mu \mathrm{g} / \mathrm{l}$. Six concentrations ranging from 2-200 $\mu \mathrm{g}$ NO3-N/ and a reagent blank were analyzed with each group of samples.

$\underline{\mathrm{NH}_{4} \mathrm{Cl}}$ Add $37.4 \mathrm{~g} \mathrm{NH} 4 \mathrm{Cl}$ to $800 \mathrm{ml} 2 \mathrm{xH}_{2} \mathrm{O}$. Adjust the $\mathrm{pH}$ to 8.5 with $\mathrm{NH}_{4} \mathrm{OH}$. Dilute to 1 liter with $2 \times 3 H 2 O$.

$\mathrm{CdSO}_{4}$ Add $60 \mathrm{~g}\left(\mathrm{CdSO}_{4} \times 8 \mathrm{H}_{2} 0\right)$ to $300 \mathrm{ml} 2 \mathrm{xH}_{2} \mathrm{O}$ in a tall beaker.

$@ \mathrm{~N} \mathrm{HCl}$ Dilute concentrated $(12 \mathrm{~N}) \mathrm{HCl} 1: 1$ with $2 \mathrm{xH}_{2} \mathrm{O}$.

Spongy cadmium Place 2-3 zinc strips into the beaker containing the $\mathrm{CdSO}_{4}$. Let cadmium precipitate onto zinc sticks overnight. Remove the zinc sticks and rinse the cadmium with $6 \mathrm{~N} \mathrm{HCl}$ for 10 minutes, breaking the cadmium up into $0.1 \mathrm{~g}$ pieces. Wash the cadmium with $2 \mathrm{xH}_{2} \mathrm{O} 10 \mathrm{x}$ or until the $\mathrm{pH}$ is above 5 . Cadmium is stored under water in a sealed container to prevent oxidation of the cadmium. Spongy cadmium can be regenerated by rewashing with the acid and rinsing with $2 \mathrm{xH}_{2} \mathrm{O}$.

Color reagent B Mix $100 \mathrm{ml}$ of $85 \%$ phosphoric acid in $800 \mathrm{ml} 2 \mathrm{xH}_{2} \mathrm{O}$. Dissolve $10 \mathrm{~g}$ sulfanilimide and $1 \mathrm{~g} \mathrm{~N}$-(1-naphthyl) ethylenediamine dihydrochloride to this solution and mix well. Once reagents are in solution, dilute to I liter with $2 \mathrm{xH}_{2} 0$. I recommend adjusting the amounts of these reagents to make only what will be used that day. Because 
Color reagent B is photosensitive, store it in an amber glass container in the dark.

Analytical Procedure Pipette $25 \mathrm{ml}$ of standard or filtered sample into $50 \mathrm{ml}$ test tubes with lids. Add $5 \mathrm{ml} \mathrm{NH} 4 \mathrm{Cl}$ solution to each tube, cap and vortex or shake well. Add approximately $1 \mathrm{~g}$ of wet spongy cadmium using a top loading balance and weighing paper. Cap tightly and place samples horizontally on a shaker (100 RPM) for 90 minutes. Pipette $20 \mathrm{ml}$ from each tube into a separate clean tube, for each sample or standard. Add $1 \mathrm{ml}$ Color Reagent $\mathrm{B}$ and incubate in the dark at $20 \pm 5^{\circ} \mathrm{C}$ for $>10$ minutes, but $<2$ hours. Read samples using a wavelength of $540 \mathrm{~nm}$, and a path length of $5 \mathrm{~cm}$.

\section{Ammonium Nitrogen}

\section{Reagents}

Ammonium standard stock solution Add $3.819 \mathrm{~g} \mathrm{NH}_{4} \mathrm{Cl}$, ovendried $\left(105^{\circ} \mathrm{C}, 24 \mathrm{~h}\right)$ to a volumetric flask and dilute to 1 liter with $2 \mathrm{xH}_{2} 0$. This produces a $1,000,000 \mu \mathrm{g} \mathrm{N} /$ stock solution, which is diluted $0.5: 100$ to produce a working solution of $5,000 \mu \mathrm{g} N / 1$. Six concentrations ranging from $10-400 \mu \mathrm{g} \mathrm{NO}_{3}-\mathrm{N} / \mathrm{l}$ and a reagent blank were analyzed with each group of samples.

$\mathrm{Na}_{3} \mathrm{PO}_{4}$ Add $5 \mathrm{~g} \mathrm{Na}_{3} \mathrm{PO}_{4}$ to $100 \mathrm{ml} 2 \mathrm{xH}_{2} \mathrm{O}$.

Phenol stock Dissolve $500 \mathrm{~g}$ phenol in $800 \mathrm{ml}$ methanol. Care should be exercised because phenol is toxic. Experience shows that this can be stored in a refrigerator for 6 months or until it has a dark tinge to it. 
$27 \% \mathrm{w} / \mathrm{v} \mathrm{NaOH}$ Add $27 \mathrm{~g} \mathrm{NaOH}$ to $2 \mathrm{xH}_{2} \mathrm{O}$ and dilute to $100 \mathrm{ml}$ with $2 \mathrm{xH}_{2} 0$; cool before use.

Phenate reagent A Add $15 \mathrm{ml}$ phenol stock and $0.02 \mathrm{~g}$ sodium nitroprusside and dilute to $100 \mathrm{ml}$ with $2 \mathrm{xH}_{2} \mathrm{O}$. Store in the dark.

Phenate reagent B Add $15 \mathrm{ml}$ sodium hypochlorite (or fresh chlorine bleach of $5 \%$ chlorine) to $15 \mathrm{ml}$ of the $27 \% \mathrm{NaOH}$ and dilute to $50 \mathrm{ml}$ with $2 \mathrm{xH}_{2} 0$. Keep in the dark.

\section{Analytical Procedure}

Pipette $25 \mathrm{ml}$ of standard or filtered sample into $50 \mathrm{ml}$ test tubes with lids. Add 1 $\mathrm{ml} \mathrm{Na} \mathrm{PO}_{4}$ solution to each tube, cap and vortex or shake well. Add $2.5 \mathrm{ml}$ Phenate reagent A. Add $1.25 \mathrm{ml}$ Phenate reagent $B$ and incubate for $>60$ minutes, but $<24$ hours. Read samples using a wavelength of $630 \mathrm{~nm}$ and a path length of $5 \mathrm{~cm}$.

\section{Total Nitrogen}

\section{$\underline{\text { Reagents }}$}

Nitrogen standard stock solution The same standard stock solution prepared for the nitrate + nitrite analysis is used.

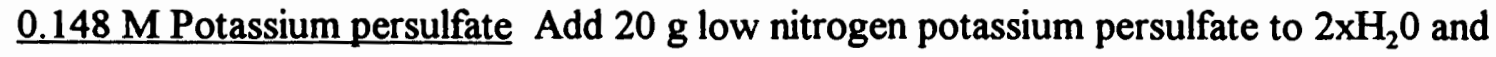
dilute to $500 \mathrm{ml}$ with $2 \mathrm{xH}_{2} \mathrm{O}$.

3 N Sodium hvdroxide Add $12 \mathrm{~g} \mathrm{NaOH}$ to $2 \mathrm{xH}_{2} \mathrm{O}$ and dilute to $100 \mathrm{ml}$ with $2 \mathrm{xH}_{2} \mathrm{O}$. 


\section{Analytical Procedure}

Pipette $15 \mathrm{ml}$ of standard or unfiltered sample into $40 \mathrm{ml}$ digestion tubes.

Borosilicate glass screw-top vials with autoclavable rubber lined caps (Fisher Scientific® 03-339-22N) are used. Caps are lined with teflon (PTFE) liners (Scientific Specialties Services, Inc. B68800-24). Five $\mathrm{ml}$ of potassium persulfate and $250 \mu \mathrm{l} \mathrm{NaOH}$ are added to each tube. Tubes are tightly sealed, vortexed, and autoclaved for 55 minutes at $121^{\circ} \mathrm{C}$ and 17 PSI. After cooling, $250 \mu \mathrm{l} \mathrm{NaOH}$ are added to each tube. Samples can be refrigerated for $\mathbf{2 8}$ days before analysis. Analysis is done using the cadmium reduction method described above.

Soluble Reactive Phosphorus (SRP)

\section{$\underline{\text { Reagents }}$}

Phosphorus standard stock solution Add $0.2197 \mathrm{~g} \mathrm{KH}_{2} \mathrm{PO}_{4}$, ovendried $\left(105^{\circ} \mathrm{C}, 24 \mathrm{~h}\right)$, to a volumetric flask with $1 \mathrm{ml}$ of chloroform and dilute to 1 liter with $2 \mathrm{xH}_{2} \mathrm{O}$. This produces a $50,000 \mu \mathrm{g} P / /$ stock solution, which is diluted 1:100 to produce a working solution of 500 $\mu \mathrm{g} /$. Six concentrations ranging from $1-100 \mu \mathrm{g} / /$ and a reagent blank were analyzed with each group of samples.

Ammonium molybdate Add $15 \mathrm{~g}$ ammonium paramolybdate to a volumetric flask and dilute to $500 \mathrm{ml}$ with $2 \mathrm{xH}_{2} \mathrm{O}$. This reagent has a shelf life of $2-3$ months if stored in a dark bottle.

Sulfuric acid Add $135 \mathrm{ml}$ concentrated sulfuric acid to a volumertic flask and dilute to 1 
liter with $2 \mathrm{xH}_{2} \mathrm{O}$. Store in a stoppered glass bottle.

Ascorbic acid Add $2.7 \mathrm{~g} \mathrm{~L}$-ascorbic acid to $50 \mathrm{ml} 2 \mathrm{xH}_{2} 0$.

Potassium antimonyl-tartrate Add $0.34 \mathrm{~g}$ potassium antimonyl-tartrate to $250 \mathrm{ml} 2 \mathrm{xH}_{2} \mathrm{O}$, warming if necessary. Store in a stoppered glass bottle.

Composite reagent Combine $200 \mathrm{ml}$ sulfuric acid, $40 \mathrm{ml}$ potassium antimonyl-tartrate, 80 $\mathrm{ml}$ ammonium molybdate, and $80 \mathrm{ml}$ ascorbic acid solutions in an Erlenmeyer flask (in that order). This reagent is highly photosensitive. Make it fresh daily and keep it in the refrigerator, covered with Parafilm $\otimes$ to prevent dust exposure.

\section{Analytical Procedure}

Pipette $25 \mathrm{ml}$ of standard or filtered sample into $50 \mathrm{ml}$ test tubes with lids. Add $2.5 \mathrm{ml}$ composite reagent to each tube, cap and vortex or shake well. Incubate for $>10$ minutes but $<2$ hours. Read samples using a wavelength of $880 \mathrm{~nm}$ and a path length of $5 \mathrm{~cm}$.

\section{Total Phosphorus}

\section{Reagents}

Phosphorus standard stock solution The standard stock solution used for soluble reactive phosphorus is also used for total phosphorus.

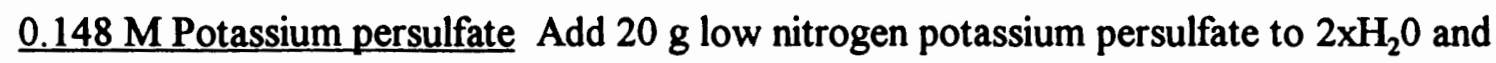
dilute to $500 \mathrm{ml}$ with $2 \mathrm{xH}_{2} \mathrm{O}$. 
$3 \mathrm{~N}$ Sodium hydroxide Add $12 \mathrm{~g} \mathrm{NaOH}$ to $2 \mathrm{xH}_{2} 0$ and dilute to $100 \mathrm{ml}$ with $2 \mathrm{xH}_{2} \mathrm{O}$.

\section{Analytical Procedure}

Pipette $15 \mathrm{ml}$ of standard or unfiltered sample into $40 \mathrm{ml}$ digestion tubes.

Borosilicate glass screw-top vials with autoclavable rubber lined caps (Fisher Scientific()) 03-339-22N) are used. Caps are lined with teflon (PTFE) liners (Scientific Specialties Services, Inc. B68800-24). Five $\mathrm{ml}$ of potassium persulfate and $250 \mu \mathrm{l} \mathrm{NaOH}$ are added to each tube. Tubes are tightly sealed, vortexed, and autoclaved for 55 minutes at $121^{\circ} \mathrm{C}$ and 17 PSI. After cooling, $250 \mu \mathrm{l} \mathrm{NaOH}$ are added to each tube. Samples can be refrigerated for 28 days before analysis. Analysis is done using the ascorbic acid method for soluble reactive phosphorus described above.

\section{Dissolved Silica}

\section{$\underline{\text { Reagents }}$}

Silica standard solution Fuse about $2 \mathrm{~g} \mathrm{NaOH}$ in a nickel crucible over a Bunsen burner and discard the $\mathrm{NaOH}$ (to clean the crucible). Fuse $1 \mathrm{~g} \mathrm{NaOH}$ with $0.5 \mathrm{~g}$ optical grade silica and let cool. Immerse the crucible on its side in a beaker of $2 \mathrm{xH}_{2} 0$. After $2 \mathrm{~h}$ pour the water and rinse the crucible with $2 \mathrm{xH}_{2} \mathrm{O}$ into a volumetric flask, making certain that all silica enters the volumetric flask. Dilute to 1 liter with $2 \mathrm{xH}_{2} 0$. This produces a $500 \mathrm{mg}$ $\mathrm{SiO}_{2} / 1$ stock solution, which is diluted $1: 100$ to produce a working solution of $5 \mathrm{mg} \mathrm{SiO}_{2} /$. Six concentrations ranging from $0.125-24 \mathrm{mg} \mathrm{SiO} / 1$ and a reagent blank were analyzed 
with each group of samples.

$\underline{0.25 \mathrm{~N} \mathrm{HCl}}$ Add $22 \mathrm{ml}$ concentrated $\mathrm{HCl}(12 \mathrm{~N})$ to a volumetric flask and dilute to 1 liter with $2 \mathrm{xH}_{2} 0$.

Ammonium molybdate Add $52 \mathrm{~g}$ ammonium molybdate to a volumetric flask and dilute to 1 liter with $2 \mathrm{xH}_{2} 0$.

Disodium EDTA Add $10 \mathrm{~g}$ disodium EDTA to a clear volumetric flask and dilute to 1 liter with $2 \mathrm{xH}_{2}$. Caution: the solubility of this reagent is low; mix well.

Sodium sulfite Add $170 \mathrm{~g}$ sodium sulfite to a volumetric flask and dilute to 1 liter with $2 \mathrm{xH}_{2} \mathrm{O}$.

\section{Analytical Procedure}

Pipette $10 \mathrm{ml}$ of standard or filtered sample into $50 \mathrm{ml}$ test tubes with lids. Add $5 \mathrm{ml}$ $0.25 \mathrm{~N} \mathrm{HCl}$ to each tube, cap and vortex or shake well. Add $5 \mathrm{ml}$ ammonium molybdate to each tube and vortex. Add $5 \mathrm{ml}$ disodium EDTA and vortex. Five minutes after the addition of the ammonium molybdate, add $10 \mathrm{ml}$ sodium sulfite and vortex. Incubate for $>30$ minutes; this solution is stable for several hours. Read samples using a wavelength of $700 \mathrm{~nm}$ and a path length of $5 \mathrm{~cm}$. 
APPENDIX C

ABBREVIATIONS USED IN THE TEXT 


\section{ABBREVIATIONS USED IN THE TEXT}

$\begin{array}{ll}\text { APA } & \text { alkaline phosphatase activity } \\ \text { Chl.-a } & \text { chlorophyll-a } \\ \text { DIN } & \text { dissolved inorganic nitrogen (nitrate+nitrite+ammonium) } \\ \text { Io } & \text { surface light intensity } \\ \text { N } & \text { Nitrogen } \\ \text { n } & \text { extinction coefficient }\left(\mathrm{m}^{-1}\right) \\ \text { P } & \text { Phosphorus } \\ \text { SD } & \text { standard deviation } \\ \text { Si } & \text { Silicon } \\ \text { SRP } & \text { soluble reactive phosphorus } \\ \text { TN } & \text { total nitrogen } \\ \text { TP } & \text { total phosphorus }\end{array}$

